\title{
Childhood, Play and Fantasy as Spiritual Revelation in the Work of Paul Klee
}

by

\section{Janine Margaret Ray}

B. A. History, University of Lethbridge, 2008

A thesis submitted to the Faculty of Graduate and Postdoctoral Affairs in partial fulfillment of the requirement for the degree of

\author{
Master of Arts \\ in \\ Carleton University \\ Ottawa, Ontario, Canada \\ 2010
}

School for Studies in Art and Culture: Art and Its Institutions

(c) 2010, Janine Margaret Ray 


\begin{abstract}
The affinities between the work of Paul Klee and children's pictures have been acknowledged in the scholarly literature. Klee's interest in childhood has been largely viewed as an alternative form of Primitivism. In this thesis, I will argue that childhood was a source of spiritual revelation for Klee. Three main ideas have been gleaned from his writings and works that confirm this notion and are examined here. One, Klee viewed children as direct expressions of the spiritual beginnings of man. Two, Klee valued a childhood that was unaffected and wild. This experience, in Klee's view, was a true state that could access the spiritual and otherworldly. Three, Klee regarded children's play and fantasy as activities that directly access cosmic and spiritual energies. The continued interest in Klee's association with children in the form of children's books and the Zentrum Paul Klee's large-scale accommodation of children's art is addressed in the conclusion.
\end{abstract}




\section{Acknowledgements}

I would first like to acknowledge Mitchell B. Frank, my thesis supervisor, for his help and guidance. I am thankful for Roger Mesley's advice in the early stages of this project.

To Susan Whitney, thank you for your interest. I am also grateful to the administrators of the Carleton University Graduate Studies Travel Bursary. The Zentrum Paul Klee provided me with generous accommodations and the collections researcher, Eva Wiederkehr-Sladeczek, was extremely helpful. The experience at the Zentrum contributed to the richness of this project. I would also like to acknowledge Paul Klee himself, whose work has added profound meaning to my experience of art and will remain close to my heart. To my mother, Linda Wilson, father, Markham Ray, stepmother Candace, and sisters Elise and Nicola, whose love and encouragement have provided me with the necessary fortitude to complete this project. For your support I am truly thankful. And, above all, to the children in my life who have the ability to draw me back from the mundane, mind-focused experience of life into one that is in the present and is true: my brother Kyle Ray, and relatives Sophia and Matteo Di Stefano. I deeply thank you. 


\section{Table of Contents}

Abstract ii

Acknowledgements iii

Table of Contents iv

List of Figures. vi

Introduction: CHILDHOOD, CHILD ART, AND PAUL KLEE ............................... 1

A Child Could Do That...................................................................2

The Spiritual in Modern Art............................................................ 5

The Problem of Childhood................................................................

The "Pure" Vision of Childhood...........................................

The Child of Nature and Beginnings.................................... 11

The Mental States of Children.............................................. 12

The Wild Child.................................................................. 14

Spiritual Accessibility in Childhood....................................... 15

Das Kind als Künstler (The Child as Artist)................................... 17

Children and Modern Art.............................................................. 19

Limits, Aims, and Organization....................................................... 22

Chapter One: "THERE WILL ONLY BE FULFILLMENT OF THE BEGINNING, AND THE BEGINNING ITSELF WAS ALREADY FULFILLMENT": CHILDHOOD

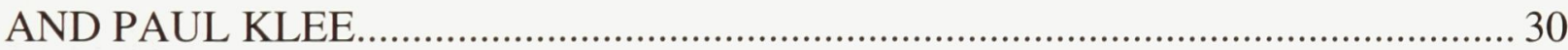

Connecting Klee to Children and Childhood: The Scholarly

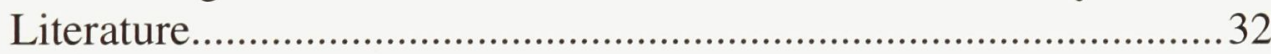

Children's Art and Primitivism..............................................32

Klee's Use of Children's Methods and Schematic Forms.... 34

Klee and the Processes of Children's Picture Making...........35

Childhood As Escape From Reality.......................................36

Child Art and War.............................................................. 37

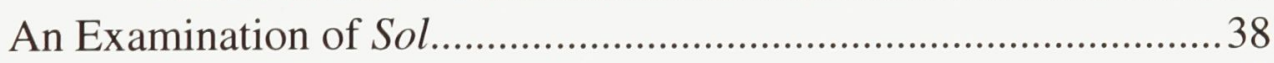

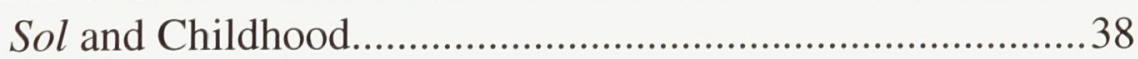

Seeking Out Beginnings: Ideas of Childhood in Klee's

Writings............................................................................. 40

Pedagogical Writings and the Influence of Children's Art...43

Complexities in Sol.............................................................4 46

The Spiritual in Childhood.............................................................. 49

Cosmic Beginnings in Childhood.......................................... 51

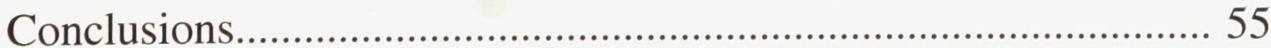


Chapter Two: PAUL KLEE AND THE WILD CHILD AS SPIRITUAL

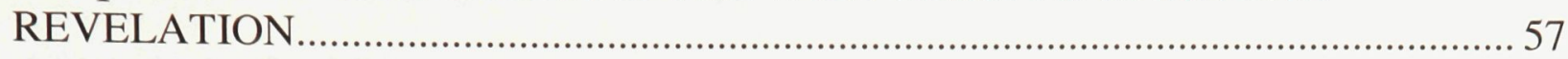

Rejecting the Schoolhouse...............................................................5

The Wild Child as a Source for Uncultivated Beginnings.................61

The Wild Children of Europe....................................................... 62

Wild Sensibilities in a Return to Childhood............................63 63

Uncultivated Sexuality in a Wild Childhood......................... 64

The Wild Child Aesthetic............................................................ 67

Higher Meaning in a Wild Childhood................................................ 70

Homeland in a Wild Childhood..................................................76

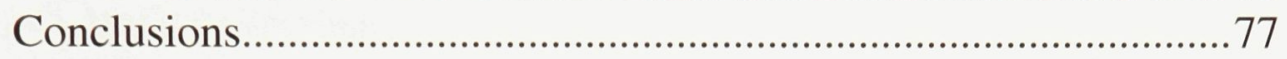

Chapter Three: THE HIGHER VALUE OF CHILD'S PLAY AND FANTASY IN

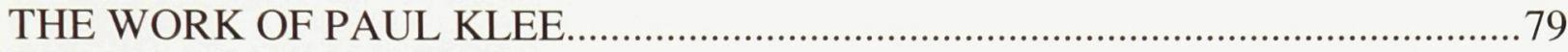

Movement Around a Child............................................................. 80

Mysticism in the Play of Children................................................... 85

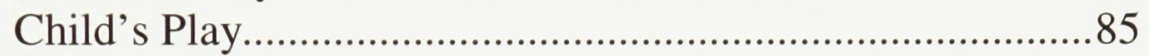

The Free and Creative Play of Children................................. 87

Mysterious and Cosmic Energy in Children's Free Play......88

The "Once Upon a Time" or Fantastical Childhood-Element in Klee's

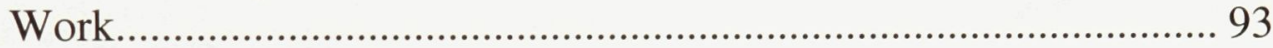

Fairy Tales in Klee's Work.........................................................96

The Deeper Meanings in Fantasy................................................. 98

Fantasy Meets Reality.............................................................100

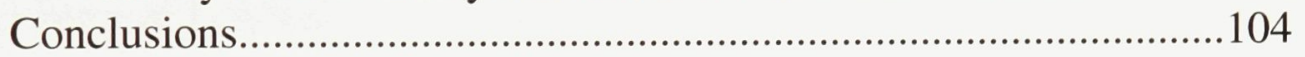

Conclusion:

Paul Klee and the Spiritual in Modern Art......................................... 106

Klee, Childhood, and the Implications for this Study .......................110

The Continued Interest in Klee and Childhood................................. 113

Paul Klee and Children's Books................................................. 113

Kindermuseum Creaviva at the Zentrum Paul Klee................... 115

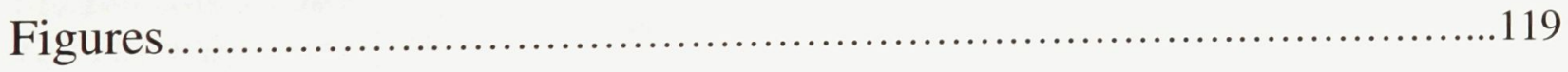

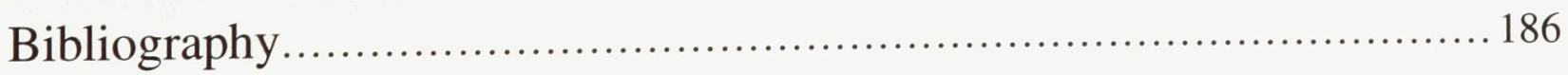


List of Figures

All works by Paul Klee unless otherwise noted.

Figure 1

Henri Matisse

The Young Sailor (II), Collioure, summer 1906

Oil on canvas

$40 \times 32 \frac{3}{4}$ in. $(101.5 \times 83 \mathrm{~cm})$

Metropolitan Museum of Art, New York, The

Jacques \& Natasha Gelman Collection

Figure 2

Philipp Otto Runge

Hülsenbeck Children, 1805-6

Oil on canvas

$131.5 \times 143.5 \mathrm{~cm}$

Hamburger Kunsthalle

Figure 3

Unknown artist

Peter the Wild Boy, early $19^{\text {th }}$ century

Stipple engraving

19.4 x $13.4 \mathrm{~cm}$

National Portrait Gallery of London

Figure 4

Unknown artist

Portrait of Victor, c. early $17^{\text {th }}$ century

Frontispiece of Jean Itard's De l'Êducation d'un homme sauvage, ou des premiers développements physiques et moraux du jeune sauvage de l'Aveyron

Paris, 1801

Figure 5

Philipp Otto Runge

The Great Morning 1809-10

Oil on canvas

$152 \times 113 \mathrm{~cm}$

Hamburger Kunsthalle

Figure 6

Kazimir Malevich

Woman in Childbirth, 1908

Oil and pencil on board

$24.7 \times 25.6 \mathrm{~cm}$

The George Costakis Collection 
Thessaloniki, Greece

Figure 7

Child's drawing

Plate 10, from Georg Kerschensteiner,

Die Entwicklung der zeichnerischen Begabung

(The Development of the Gift of Drawing)

Munich, 1905

Figure 8

Paula Modersohn-Becker

Drei Kinder an einem Hang sitzend mit Hund und Pferd, 1901

Oil on cardboard mounted on wood

Galerie Ludorff, Düsseldorf

Figure 9

Lady with Parasol, c. 1883-1885

Pencil on paper

$43 / 8 \times 3 \frac{1}{4}$ in. $(11.2 \times 8.2 \mathrm{~cm})$

Paul Klee-Stiftung, The Zentrum Paul Klee

Figure 10

Horsedrawn Carriage, c. 1883-1885

Pencil and coloured crayon

$41 / 8 \times 53 \frac{3}{4}$. $(10.6 \times 14.7 \mathrm{~cm})$

Private collection, Bern

Figure 11

A Cart with Two Horses, Just Before Departure, 1908

Ink and watercolour on paper on cardboard

$11.3 \times 17.8 \mathrm{~cm}$

Galerie Rosengart, Luzern

Figure 12

Child's Drawing, Portraying Five Sisters, c. 1885-1889

Coloured pencil on paper on cardboard

$18.3 / 16$ x 14/13.3 cm

Private Swiss Collection

Figure 13

A Sick Girl Being Visited by Some Girlfriends, Five Figures, 1909

Ink on paper on cardboard

$16.9 \times 31.5 \mathrm{~cm}$

Paul Klee-Stiftung, The Zentrum Paul Klee 
Figure 14

Five Girls, 1910

India ink and watercolour on paper on cardboard

$17.8 \times 11.5 \mathrm{~cm}$

Kunsthaus Zürich

Figure 15

Scene of a Drama, 1923

Watercolour and plaster on nettle cloth, above and below edge strip with watercolour and ink, on cardboard

$31 \times 47 \mathrm{~cm}$

Location unknown

Figure 16

Child and the Star, 1912

Pencil on paper

$8.2 \times 10 \mathrm{~cm}$

Private collection, Switzerland

Figure 17

Child's drawing

Plate 101, from Georg Kerschensteiner,

Die Entwicklung der zeichnerischen Begabung

(The Development of the Gift of Drawing)

Munich, 1905

Figure 18

Human Helplessness, 1913

Tusche on paper

$8.2 \times 10 \mathrm{~cm}$

Paul Klee-Stiftung, The Zentrum Paul Klee

Figure 19

Gate in the Garden, 1926

Oil on cardboard

$54.5 \times 44 \mathrm{~cm}$

The Paul Klee-Stiftung, The Zentrum Paul Klee

Figure 20

The Game Degenerates, 1940

Pencil on paper

$20.9 \times 29.6 \mathrm{~cm}$

Paul Klee-Stiftung, The Zentrum Paul Klee 
Figure 21

Sol, 1920

Ink on paper

$18.6 \times 28.3 \mathrm{~cm}$

The National Gallery of Canada

Figure 22

Child's drawing

Plate 60, from Georg Kerschensteiner,

Die Entwicklung der zeichnerischen Begabung

(The Development of the Gift of Drawing)

Munich, 1905

Figure 23

Child's drawing

Plate 76, from Georg Kerschensteiner,

Die Entwicklung der zeichnerischen Begabung

(The Development of the Gift of Drawing)

Munich, 1905

Figure 24

The Unborn is Integrated in Its Future. There Will Be Only Fulfillment Of The

Beginning, And The Beginning Itself Was Already Fulfillment, 1913

Ink on paper on cardboard

$15 \times 21 \mathrm{~cm}$

Private collection, Germany

Figure 25

Schoolhouse, 1920

Oil on paper on cardboard

$37 \times 29 \mathrm{~cm}$

The Art Institute of Chicago

Collection of Mr. and Mrs. Leigh B. Block

Figure 26

Fish Magic, 1925

Oil and watercolour on canvas

$77.5 \times 98.4 \mathrm{~cm}$

Philadelphia Museum of Art

Figure 27

Johann Georg Laminit

The Young Kaspar Hauser, 1828-9

British Library 
Figure 28

Sexual Discoveries of a Boy, 1918

Watercolour, ink, and plaster on paper on cardboard

$22.8 / 22 \times 24 \mathrm{~cm}$

Private collection, Switzerland

Figure 29

A Child's Villa, 1923

Pencil on paper on cardboard

$22 \times 28.7 \mathrm{~cm}$

Private collection, Switzerland

Figure 30

The Pony, 1918

Watercolour on paper on cardboard

$13.5 \times 21.2 \mathrm{~cm}$

Location unknown

Figure 31

Scene in the Restaurant, 1911

Pencil and ink on paper on cardboard

$13 \times 23 \mathrm{~cm}$

Felix Klee collection, The Zentrum Paul Klee

Figure 32

Kindergarten, 1939

Coloured paste and ink on paper, mounted on cardboard

29.4 x $20.7 \mathrm{~cm}$

Private collection, U.S.A.

Figure 33

Childhood of the Chosen One, 1930

Coloured paste and watercolour on paper, above and below edge strip with watercolour and ink, on cardboard

$23.9 \times 30.5 \mathrm{~cm}$

Sammlung Rosengart, Luzern

Figure 34

Child as Hermit, 1920

Oil and tusche on paper

$19.3 \times 26.4 \mathrm{~cm}$

Kasama Nichido Museum of Art, Kasami-City, Japan 
Figure 35

Oracle, 1919

Oil on paper on cardboard

$33.8 \times 19 \mathrm{~cm}$

Location unknown

Figure 36

Ferdinand Holder

The Chosen One, 1893-94

Tempura and oil on canvas

$219 \times 296 \mathrm{~cm}$

Kunstmuseum, Bern

Figure 37

Homeland, 1929

Oil, ink and watercolour, mounted on cardboard

$28.4 \times 37.5 \mathrm{~cm}$

Location unknown

Figure 38

Psycho-Recording Apparatus, 1920

Pen and ink on paper mounted on cardboard

$21.6 \times 29.4 \mathrm{~cm}$

Norton Museum of Art, West Palm Beach

Donation of Melvin and Barbara Nessel

Figure 39

Movement Around a Child, 1928

Oil and watercolour on paper, above and below edge strip with watercolor and ink, on cardboard

$20.2 \times 30.2 \mathrm{~cm}$

The Saint Louis Art Museum

Donation of Mrs. Richard K. Weil

Figure 40

Mystical-Physiognomic, 1924

Ink and watercolour on paper, above and below edge strip with watercolour and ink, on cardboard

$13.5 \times 13.5 \mathrm{~cm}$

Location unknown

Figure 41

Two Men Meet: Each Supposing The Other To Be of Higher Rank, 1902

Etching on zinc

$11.8 \times 22.6 \mathrm{~cm}$ 
Paul Klee-Stiftung, The Zentrum Paul Klee

Figure 42

Children as Actors, 1913

Ink and pencil on paper

$6.6 \times 16.5 \mathrm{~cm}$

Paul Klee-Stiftung, The Zentrum Paul Klee

Figure 43

Girl With Doll, 1905

Painting behind glass with watercolour

$18 \times 13 \mathrm{~cm}$

Paul Klee-Stiftung, The Zentrum Paul Klee

Figure 44

Paul and Fritz, 1905

Painting behind glass with watercolour

$13 \times 18 \mathrm{~cm}$

Paul Klee-Stiftung, The Zentrum Paul Klee

Figure 45

Children at Play Forming a Chain, 1928

Ink and watercolour on paper on cardboard

$38 \times 47 \mathrm{~cm}$

Galerie Thomas, Munich

Figure 46

Child with Skipping Rope, 1925

Watercolour and paste on paper on cardboard

$21 \times 21.6 \mathrm{~cm}$

Private collection, USA

Figure 47

Sets for Punch and Judy Puppet Theater, 1922

Destroyed World War II

Photograph from Paul Klee: His Life and Work and Documents. Ed. Felix Klee, Trans.

Richard and Clara Winston. New York: Braziller, 1962.

Figure 48

Self-Portrait [Puppet], 1922

Head: cow bone and plaster, robe: want material

$38 \mathrm{~cm}$

Donation of Lily Klee, The Zentrum Paul Klee

Figure 49

There Once was a Child Who Never Wanted, 1920 
Ink and watercolour on paper on cardboard $28.3 \times 18.7 \mathrm{~cm}$

Private collection, Switzerland

Figure 50

Brewing Witches, 1922

Ink on paper on cardboard

$18.8 \times 22 \mathrm{~cm}$

Private collection, USA

Figure 51

A Witch Threatens Four Children, 1922

Ink and pencil on paper on cardboard

$10.2 \times 23.8 \mathrm{~cm}$

Paul Klee-Stiftung, The Zentrum Paul Klee

Figure 52

Witch, Dispatching Her Animals, 1924

Ink on paper on cardboard

$10.2 \times 23.8 \mathrm{~cm}$

San Francisco Museum of Modern Art

Collection of Carl Djerassi

Figure 53

Ironic Fairy Tale, 1925

Ink and watercolour on paper on cardboard

$11.2 \times 22.4 \mathrm{~cm}$

Sammlung Rosengart, Luzern

Figure 54

End of the Marionette, 1927

Ink and watercolour on paper on cardboard $32.5 \times 45.5 \mathrm{~cm}$

Location unknown

Figure 55

Childhood, 1938

Coloured paste on paper

$27 \times 42.8 \mathrm{~cm}$

Paul Klee-Stiftung, The Zentrum Paul Klee

Figure 56

Photograph by the author, 2010

Paul Klee gravesite

Bern, Switzerland 
Figure 57

Untitled, 1905

Oil on cardboard

$27.7 \times 37 \mathrm{~cm}$

The Art Museum, Princeton University

Collection of John Maclean Magie and Gertrude Magie

Figure 58

Untitled, 1905

Oil on cardboard

$32 \times 21.5 \mathrm{~cm}$

Private Swiss collection

Figure 59

A Children's Game, 1939

Coloured paste and watercolour on cardboard

$43 \times 32 \mathrm{~cm}$

Die Sammlung Berggruen in den Staatlichen Museen zu Berlin

Figure 60

Photograph by the author, 2009

The Zentrum Paul Klee

Figure 61

Image from the website, www.creaviva-zpk.org

Kindermuseum Creaviva studio

The Zentrum Paul Klee

Figure 62

Children and their instructor in discussion of Klee's work

Image from website, www.creaviva-zpk.org

Kindermuseum Creaviva studio

The Zentrum Paul Klee

Figure 63

Ad Parnassum, 1932

Oil and casein colour on linen

$100 \times 126 \mathrm{~cm}$

Kunstmuseum, Bern

Figure 64

Child's painting

Image from website, www.creaviva-zpk.org

Kindermuseum Creaviva studio

The Zentrum Paul Klee 
Figure 65

Child's drawing

Kindermuseum Creaviva studio

Image taken from the website, www.creaviva-zpk.org

Collection of Hans Hochreuter

The Zentrum Paul Klee

Figure 66

Child's drawing

Kindermuseum Creaviva

Image from website, www.creaviva-zpk.org

Collection of Hans Hochreuter

The Zentrum Paul Klee

Figure 67

Colour Table (In Grey Major)

Oil pastel on paper on cardboard

37.7 x $30.4 \mathrm{~cm}$

Paul Klee-Stiftung, The Zentrum Paul Klee 


\section{Introduction}

\section{Childhood, Child Art, and Paul Klee}

The work of Swiss artist Paul Klee has been long acknowledged for its engagement with children's pictures. While childhood is only one the of many vocabularies in Klee's extensive oeuvre, it is a significant aspect to his work. ${ }^{1}$ Marcel Franciscono, for example, writes:

Throughout his career Klee's work exhibits many of the features commonly attributed to the drawings of very young children: scribbled forms; a diagrammatic simplicity of composition; and figures (...) reduced to mere sticks. ${ }^{2}$

Jonathan Fineberg, moreover, has shown that a profound interest in childhood was common to nearly every advanced artist of Klee's generation. ${ }^{3}$ In line with modern, antiacademic ideals and notions of primitivism, children's pictures offered early twentiethcentury avant-garde artists a natural and meaningful source for their work: "pure" manifestations of uncultivated minds and imaginations.

This project will expand upon the existing literature on Klee's connection to children's art to suggest that Klee not only employed a childlike aesthetic, but also explored a variety of childhood themes and associations in his pursuit of artistic authenticity. All facets of the notion of childhood - fantasy, imagination, play, innocence, unencumbered senses, closeness to nature and animals - come together as a vehicle for Klee to reach

\footnotetext{
${ }^{1}$ See Marcel Franciscono, Paul Klee, His Work and Thoughts (Chicago: University of Chicago Press, 1991).

2 Marcel Franciscono, "Paul Klee and Children's Art," in Discovering Child Art: Essays on Childhood, Primitivism, and Modern Art, ed. Jonathan Fineberg (Princeton, New Jersey: Princeton University Press, 1998), 95.

${ }^{3}$ Jonathan Fineberg, The Innocent Eye: Children's Art and the Modern Artist (Princeton: Princeton University Press, 1997), 82.
} 
something whole and deeply expressive in the quest for his ultimate source and meaning as an artist. This introduction will establish my central thesis that Klee's interest in childhood was a spiritual pursuit. I begin with a discussion of how modern artists like Klee viewed their work in a spiritual manner. I then thematically explore the "problem" of the child in early twentieth-century Europe to illustrate its many aspects. I refer back to this introductory examination of childhood in my later discussions of how Klee drew upon and incorporated different characteristics of childhood in his work. Finally, I close this section with a chapter breakdown, a description of methodology, and a definition of key terms I use throughout this project.

\section{A Child Could Do That}

According to a longstanding cliché, much modern art could have been done by a child. ${ }^{4}$ Claiming a work is "childlike" can be a severe criticism and a gross simplification of an artist's intellectual pursuits. Such a claim can also undermine an artist's intention to overhaul ingrained conceptions of art itself. In some cases, artists denied their associations with childhood. For example, according to Leo Stein, Matisse pretended the postman had painted his highly abstract work, The Young Sailor (II), 1906 (fig. 1), which is reminiscent of the work of a child, before reluctantly admitting that he had painted it himself. ${ }^{5}$

Marxist art historian Otto Karl Werckmeister suggests that Klee also wanted to avoid

\footnotetext{
${ }^{4}$ For a discussion of this cliché of Modern Art, see Robert Goldwater, Primitivism in Modern Art (New York: Vintage Books, 1967), 178-191.

${ }^{5}$ I owe this information to Jonathan Fineberg and his article, "The Postman Did It," in The Innocent Eye, 2-23.
} 
"infantile" accusations about his art. ${ }^{6}$ In fact the artist eliminated some direct references to childhood in his text, Creative Credo, before its publication. ${ }^{7}$ Moreover, Klee announced in his talk On Modern Art that "the tale of infantilism in my work" is a

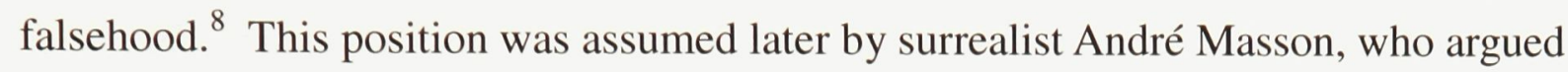
against the link between Klee and children. ${ }^{9}$ Klee and Masson were calling for recognition of the highly intellectual and complex philosophy behind Klee's use of childhood. This complexity is outlined in his writing and exemplified in his art.

From early on, when Klee was gaining popularity as an artist, his work was likened to children's pictures. Many contemporary writers were sympathetic to Klee's aim in seeking out the creative vision of childhood. Theodor Däubler, for example, characterized Klee in 1918 as a "painter who perceives like a child in his adult age.",10 Paul F. Schmidt, in his "Kinderzeichnungen” of 1929, similarly praised Klee's attempts to regain an imaginative and child-like quality in his art. ${ }^{11}$ Notably it is Hans-Friedrich Geist who most steadfastly defended Klee's use of children's art. In "Kinder über Paul Klee" of 1930, he writes of how Klee learnt to "reject the bankruptcy of the intellect" and to return home to the world of the child. ${ }^{12}$ Finally, Rudolph Arnheim, in "Klee für Kinder," remarks on the essence of children's pictures in Klee's art. For Arnheim, Klee's

${ }^{6}$ See Otto Karl Werckmeister, The Making of Paul Klee's Career, 1914-1920 (Chicago: University of Chicago Press, 1989), 245-247.

${ }^{7}$ Werckmeister, "The Issue of Childhood in the Art of Paul Klee," Arts Magazine 52, no. 1 (September 1977): 151-188.

${ }^{8}$ Paul Klee, On Modern Art (London: Faber and Faber, 1948), 53.

${ }^{9}$ André Masson, The Eulogy of Paul Klee (1946) trans. Walter Pach (New York: Valentin, 1950), para. 9.

10 Theodor Däubler, “Paul Klee,” Das Kunstblatt, 2 (1918): 24-27.

${ }^{11}$ Paul F. Schmidt, "Kinderzeichnungen," Das Tagebuch 10, no. 47 (Nov. 1929): 20032004.

${ }^{12}$ Hans-Friedrich Geist, “Kinder über Paul Klee,” Das Kunstblatt 14, no. 1 (1930): 21. 
work was remarkable in its borrowing from the work of little children and for turning academic art training on its head. ${ }^{13}$

There was, however, also a negative reaction to Klee's association with childhood. Although attacks on Klee focussed on diverse issues, they were consistent on two principal points. First, Klee was viewed as simply mad by some critics and their description of his work as frantic "scrawls" was a testament to this. For example, German art critic, Robert Scholz, presents Klee's art as “mad, infantile smearings."14 Second, Klee was also viewed by critics as inauthentic in his use of childhood. E. H., the reviewer of the large Klee exhibition at the Goltz gallery in Munich (1920), remarked that "one took pleasure with this seemingly child-like and naïve mind," but also grew tired of "the machinery (...) with which the richness of genuine children's fantasy ha[d] been replaced."15

Klee's return to childhood in art, however, was anything but a simple process of regaining naïveté. In this thesis, I discuss how Klee's endeavour to return to a space of childhood was a meaningful process through which he attempted to reach spiritual awareness. Childhood, for Klee, was a space of imagination and play; it was close to man's "beginnings" and nature. Pursuing spiritual meaning and attempting to project through his art a type of ultimate value, Klee turned back to a childlike sensibility.

${ }^{13}$ Rudolph Arnheim, “Klee für Kinder,” Die Weltbühne 26 (1930): 170-173.

${ }^{14}$ Robert Scholz, "Kunstgötzen stürzen," Deutsche Kultur-Wacht 10 (1933): 5, as quoted in Werckmeister, "The Issue of Childhood in the Art of Paul Klee," 149.

${ }^{15}$ E. H., "Paul Klee. Leben, Werk," Kunstchronik und Kunstmakt, Neue Folge 31 (1920): 725; W. Wolfradt, "Der Fall Klee," Freie deutsche Bühne, 1 (1920): 2123-26. 


\section{The Spiritual in Modern Art}

According to the American art critic and philosopher Arthur C. Danto, there was new value placed on introspection from the eighteenth century into the twentieth and, more broadly, on the existential purpose of art for wider humanity. ${ }^{16}$ Similarly, art historian Lynn Gamwell tells us of a common development in modern art: a gradual elimination of representational forms in order to communicate things of a higher nature, or those things invisible to us in the physical world. ${ }^{17}$ Modern artists not only hoped to awaken this spiritual yearning in the viewer, but searched at the same time for their own transcendence in the process. Gustav Hartlaub, the assistant director of the Kunsthalle in Mannheim, for example, equated German Expressionism with Gnosticism and Theosophy. ${ }^{18}$ He postulated that contemporary painting was leading society to a new conception of the world that opened "in modern man the vision of an immense reintegration of long lost archetypes of mystical forms of thought and experience."19

More recently, Sixten Ringbom includes Klee in a list of modern artists who pursued the spiritual in art. Ringbom states: "[Wassily] Kandinsky, Klee, [Piet] Mondrian, [Theo van] Doesburg, and other abstract pioneers [such as Frantisek Kupka and Kazimir Malevich] made claims to supernatural knowledge in stating that they had penetrated the

\footnotetext{
${ }^{16}$ Arthur Danto, Mysticism and Morality: Oriental Thought and Moral Philosophy (New York and London: Basic Books Inc., Publishers, 1972), 43, 59, 89.

${ }^{17}$ Lynn Gamwell, Exploring the Invisible: Art, Science, and the Spiritual (Princeton and Oxford: Princeton University Press, 2002), see introduction.

${ }^{18}$ See Rose-Carol Washton Long, "Expressionism, Abstraction, And the Search for Utopia in Germany," in The Spiritual in Art: Abstract Painting 1890-1985, ed. Maurice Tuchman (Los Angeles County Museum of Art Exhibition Catalogue, New York: Abbeville Press, 1986), 207-208.

${ }^{19}$ G. F. Hartlaub, "Die Kunst und die neue Gnosis," Das Kunstblatt 6 (June 1917): 178, 177, 166; also quoted in Rose-Carol Washton Long, "Expressionism, Abstraction, And the Search for Utopia in Germany," 207-208.
} 
outer shell of nature while still upholding the connection with the cosmos and its laws." 20 In addition to this cosmic connection, Klee has also been acknowledged for linking his own artistic process to the ultimate act of Creation and Genesis. Judi Freeman, for example, references a line in Klee's Creative Credo (1920) to illustrate this: "[artistic work is] similar to Creation [and] only the slightest breath is needed to transform religious feeling, religion into fact." ${ }^{21}$ Aside from these investigations, however, Klee's connection to spirituality has barely been mentioned in art-historical scholarship.

This gap in the literature is compelling, given that many of Klee's artistic contemporaries as well as his colleagues at the Bauhaus are associated with the spiritual in art. Charlotte Douglas, for example, has identified spiritual concerns in the work of Kasimir Malevich and scholars like Carel Blotkamp and Robert Welsh have made these connections in the art of Piet Mondrian. ${ }^{22}$ Art historians like Roger Lipsey and RoseCarol Washton Long have similarly explored issues of spirituality in Kandinsky's art, especially his interest in Theosophy, an all-encompassing spiritual movement that looked to ancient mythology, Judaism, Buddhism, and the occult. ${ }^{23}$ Theo van Doesburg, the

${ }^{20}$ Sixten Ringbom, "Transcending the Visible: The Generation of the Abstract Pioneers," in The Spiritual in Art, ed. Maurice Tuchman, 150.

${ }^{21}$ Judi Freeman, "Chronologies: Artists and the Spiritual," in The Spiritual in Art, 406.

22 Charlotte Douglas, "Beyond Reason: Malevich, Matiushin and Their Circles," in The Spiritual in Art, 77; Carel Blotkamp, The Art of Destruction (London: Reaktion Books Ltd., 1991), 36, 38, 77, 110; Robert Welsh, Piet Mondrian's Early Career: The "Naturalistic" Periods (New York: Garland, 1977), 171.

${ }^{23}$ Wassily Kandinsky, "Uber die Formfrage," in Der Blaue Reiter, New Edition (Munich, 1965), 128, 135; Peter Washington, Madame Blavatsky's Baboon: Theosophy and the Emergence of the Western Guru (London: Secker \& Warburg, 1993); René Guénon. Theosophy: History of a Pseudo-Religion (1921) (New York: Sophia Perennis, 2004); see also Wassily Kandinsky's "Art Without Subject" (Stockholm, 1916), in Kandinsky. Complete Writings on Art, ed. Kenneth C. Lindsay and Peter Vergo, vol. 1 (Boston, Mass.: G. K. Hall \& Co., 1982); Roger Lipsey, The Spiritual in Twentieth-Century Art (Boston and Shaftesbury: Shambhala, 1988), 40-51; Sixten Ringbom "Transcending the 
founder of De Stijl who spent time lecturing in Weimar and organized some classes at the

Bauhaus from 1920-1922, has been studied for his use of abstraction and reduction of form to express spiritual harmony. ${ }^{24}$ I argue in this thesis that Klee, like these artists, searched for spiritual meaning through his art. Unlike his contemporaries, however, Klee turned to childhood and children's art as the main source for his search.

\section{The Problem of Childhood: A Twentieth Century Dilemma}

\section{The "Pure" Vision of Childhood}

By the twentieth century, childhood was associated with many different qualities. One can even speak of multiple conceptions of childhood. ${ }^{25}$ One of the these qualities is purity: the notion that children possess a fresh vision in their unaffected innocence. This line of thinking can be traced back to Enlightenment thinkers like John Locke, who influentially described the infant child as a tabula rasa, a blank slate waiting to be inscribed with meaning derived from sense experience. ${ }^{26}$ Another important figure in this

Visible: The Generation of the Abstract Pioneers," in The Spiritual in Art, 131-156; Carol Washton Long, "Expressionism, Abstraction, And the Search for Utopia in Germany," in The Spiritual in Art, ed. Maurice Tuchman, 201-211.

${ }^{24}$ Paul Overy, De Stijl (London: Thames and Hudson, 1991), 156; Michael White, De Stijl and Dutch Modernism (Manchester: Manchester University Press, 2003).

${ }^{25}$ Peter Coveney, in The Image of Childhood (Baltimore: Penguin Books, 1967), discusses conceptions of childhood as multi-faceted; Colin Heywood, in A History of Childhood (Cambridge: Polity Press and Blackwell Publishing, 2001), notes the shifting character and conceptions of childhood; Colin Ward also looks at different ideas about children depending on their geographical context - for example, the child of the city versus the child of the country. See Ward, The Child in the Country (London: Robert Half, 1988). See also Heywood, Growing Up in France (Cambridge and New York: Cambridge University Press, 2007); Michael Newton, in Savage Girls and Wild Boys (New York: St. Martin's Press, 2003), discusses feral children and relates how these images or ideas of wild children affected conceptions of childhood.

${ }^{26}$ John Locke discusses the tabula rasa in his Two Treatises on Government, ed. Peter Laslett (Cambridge: Cambridge University Press, 1988), Book II, 428; Many historians 
discussion is Rousseau, an author known to Klee. ${ }^{27}$ In his Ėmile, or On Education (1762), Rousseau presents children as originally pure. ${ }^{28}$ Moreover, Rousseau's contrat sociale suggests that children are born with the innocence of nature and animals, but as soon as they are removed from their natural states, they become tainted through familial and social institutions. ${ }^{29}$ Rousseau's influential work emphasizes that children occupy a sensitive, "special class" and suggests that they should be encouraged to connect to nature, animals, and to the imaginative and creative reaches inherently known to them. ${ }^{30}$ Various Romantic artists soon took up this vision of the child. However, as historian Colin Heywood relates, they developed a highly idealized notion of childhood as a lost and idyllic realm. ${ }^{31}$

This Romantic interest, referred to as the "cult of childhood" by George Boas, is reflected in art and writings from various countries. ${ }^{32}$ William Blake's Songs of Innocence (1789) praised children and babies; William Wordsworth believed that "the

discuss the influence of Locke's "blank slate" on conceptions of childhood, see Coveney, The Image, 37-40; Boas, The Cult Of Childhood, 43; Heywood, A History, 23-4, 35; Hugh Cunningham, Children and Childhood In Western Society Since 1500 (London and New York: Longman, 1995), 73.

${ }^{27}$ Klee, The Diaries, Diary III, 1905, entry 685, 185. Klee mentions Rousseau in this entry and discusses his thoughts about Rousseau's Confessions (1846), a work that Colin Heywood recognizes as one of the first autobiographies to give importance to childhood. See Heywood, Growing Up, 17-18.

${ }^{28}$ See Heywood, Growing Up, 52. Heywood cites Maurice Cranston, The Noble Savage: Jean-Jacques Rousseau 1754-1762 (Chicago: University of Chicago Press, 1991), ch. 7; Boas, The Cult, 29, 35, 39, 42, 50; Coveney, The Image, 33, 43-44, 290.

${ }^{29}$ Rousseau, The Social Contract (1762) ed. Paul Negri and Drew Silver (Mineola, N.Y.: Dover Publications, 2003), Book I, Chapter 1: "Subject of the First Book."

${ }^{30}$ Heywood, Growing Up, 52. Heywood acknowledges the great popularity of Rousseau's work with the reading public of France and the rest of Europe.

${ }^{31}$ Heywood states: "Whereas Enlightenment thinkers considered childhood as a time for education, the Romantics saw it as a lost realm that was nonetheless fundamental to the shaping of the adult self." See Heywood, Growing Up, 59.

${ }^{32}$ Boas, The Cult of Childhood. 
Child is Father of the Man" and recognized the sublimity of children in their sweet and innocent natures (c. 1820). ${ }^{33}$ Caspar David Friedrich wrote that "the only true source of art is our heart, the language of a pure childlike spirit," while Philipp Otto Runge suggested that "we must become like children if we want to achieve our best." Furthermore, Victor Hugo's poem Les Griffonages de l'Ecolier (1877) glorified the unaffected artistic genius of a child. ${ }^{35}$ In this tradition, children were no longer seen as deficient adults, as they had been in earlier times, but as complete and unspoiled beings who deteriorate as they age. ${ }^{36}$

Especially relevant to my discussion of Klee's engagement with childhood are the references to a childlike and naïve vision found in the German Idealist Aesthetic tradition. For example, the writings of Friedrich von Schiller and Johann Wolfgang von Goethe, each of whom are mentioned in Klee's diaries, present the naïveté of childhood

${ }^{33}$ William Blake, "Songs of Innocence," in The Complete Poems, ed. Alicia Ostriker (Harmondsworth, Middlesex: Penguin Books, 1977), 110-115; William Wordsworth, "My heart leaps up when I behold," in The Oxford Authors: William Wordsworth, ed. Stephen Gill (Oxford and New York: Oxford University Press, 1984), 246; William Wordsworth, "The Sublime and the Beautiful," in William Wordsworth: Selected Prose, ed. John O. Hayden (London: Penguin Books,1988), 264-267. Wordsworth states "it cannot be doubted that a child...has been visited by a sense of sublimity" because they lack fear, personal fear, endless contemplation of adulthood." Wordsworth calls for the imagination of a child, or the "eye of childhood," to reach us in our mature years.

${ }^{34}$ Sigrid Hinz ed., Caspar David Friedrich in Briefen und Bekenntnissen (Munich: Rogner and Bernhard, 1968), as quoted in Fineberg, "The Postman Did It," in The Innocent Eye, see chapter 1; Philipp Otto Runge, Hinterlassene Schriften, ed. Johann Daniel Runge, vol. 1 (1840) (Gottingen: Vandenhoeck \& Ruprecht, 1965), 7, as quoted in Werner Hofmann, "The Art of Unlearning," in Discovering Child Art, 3.

${ }^{35}$ Victor Hugo, "L'Art d'être grand-père," (1877) in Selected Poems of Victor Hugo, ed. Steven Monte (London: Routledge, 2002), 210-212. In the story, a boy named Charles tires of the text in his schoolbook and starts writing and scribbling in the margins and over the lines. Hugo praises Charles' ability to let his imagination wander, something the schoolmaster was unable to achieve or understand.

${ }^{36}$ Heyward, A History of Childhood (Cambridge: Polity Press and Blackwell Publishing, 2001), 37. 
as something immediate and truthful, and they praise children's ability to view their surroundings with untrained sight. ${ }^{37}$ According to Schiller, perceiving one's surroundings with heightened sensitivity would resonate on an equally heightened intellectual level; this is the aesthetic impulse or "play drive" necessary to original works of art and poetry. In Schiller's view, art should be a playful or spontaneous exchange between the sensuous and the intellect. ${ }^{38}$ Moreover, in On Naïve and Sentimental Poetry, Schiller calls for a return to an unaffected vision, specifically that of a child, when one's surroundings were still vivid, wondrous, and fascinating. ${ }^{39}$ Although adults could never fully return to a state of childhood due to their self-conscious, educated, and habituated ways, part of the mystery of the artist/poet, according to Schiller, was to keep childhood intact during adulthood. ${ }^{40}$ Goethe articulated a similar outlook his writings, such as in Das Märchen (The Fairytale, 1795), which transformed the realities of contemporary German life into a fantastical tale. ${ }^{41}$ Klee was almost certainly aware of Goethe's work, which uncovered new meanings in everyday reality through a naïve vision and in an engagement with fantasy. ${ }^{42}$

\footnotetext{
${ }^{37}$ Klee mentions Schiller and Goethe in his diaries, see Diary II, 1902, entry 422, 123.

${ }^{38}$ See Schiller, On the Aesthetic Education of Man: in a Series of Letters, trans. by Reginald Snell (New York: Frederick Ungar Publishing Inc., 1965), 74, 80.

${ }^{39}$ Schiller, "On Naive and Sentimental Poetry: Part 1" (1795), later published in Shorter Prose Writings (Berlin, 1800), trans. William F. Werts, Jr. (http://www.schillerinstitute.org /transl/Schiller_essays/naive_sentimental-1.html); see also Schiller, Letters on the Aesthetic Education of Man, for an example of Schiller calling for a sensual and naïve appreciation of nature that could be combined with the intellect, 38 .

${ }^{40}$ Schiller, "On Naive and Sentimental Poetry," see part 1.

${ }^{41}$ Goethe, "Das Märchen," in Friedrich von Schiller's Die Horen (1795), Friedrich Schiller@www.Wissen-im-Netz.info (accessed May $20^{\text {th }}, 2010$ ). For notes on Goethe in Klee's diary, see Diary III, June 1904, entry 548, 149. Related to this, Goethe's work, Faust, was based on a show associated with children's entertainment. See Goethe, Faust: A Tragedy, trans. Bayard Taylor, second edition (Leipzig: F. A. Brockhaus, 1881).

${ }^{42}$ Goethe is mentioned in Klee's Diaries: Diary III, 1904, entry 550, 149; in Diary II
} 


\section{The Child of Nature and Beginnings}

In the long shadow of Rousseau's "pure" child, taken with his idealized notion of the natural state of man, the idea of the "child of nature" was another prevalent theme in post-Enlightenment art and literature. ${ }^{43}$ In the German Romantic and Idealist traditions, children were regarded as innocents who mirror nature's vital forces and the irrationality of organic realms occupied by animals, trees and flowers. As Heywood relates, in the saturated streets and urban slums of modern cities, this idea of childhood was a conceptual retreat for lost innocence and a lost connection to nature. ${ }^{44}$ Schiller, for example, nostalgically glances back to a "natural" childhood and states: "So long as we were merely children of nature, we were happy and perfect; we have become free and have lost both." ${ }^{45}$ Schiller suggests that adults cannot fully regain children's connection to nature because, with adulthood, comes the responsibility and an inevitable desensitization to one's surroundings. Early nineteenth-century Romantic art explored

entry 295, 69; in Diary II, 1902, entry 375; and in Diary IV, 1917, entry 1121, 393. Although "Das Märchen" is not specifically mentioned, Klee was well versed in Goethe's work.

${ }^{43}$ In Émile, children were presented as natural beings connected to the outdoors who delight in animals before they are "removed" from this state of "nature" in the process of education and growing up. See Rousseau, Émile, 37; See also Rousseau, Discours sur l'origine et les fondements de l'inégalité parmi les hommes. Discours sur les sciences et les arts (Paris : GF Flammarion, 1992), where he states "un être agissant toujours par des principes certains et invariables," 158 . According to Rousseau, natural man is free to develop his self-love, his amour de soi, without developing selfishness and vanity (amour-propre); see also Marilyn R. Brown, Picturing Children: Constructions of Childhood between Rousseau and Freud (Ashgate: Aldershot, 2002), 71-80; Coveney, The Image, 33, 43-44, 290; and Heywood, A History, 24.

${ }^{44}$ Heywood, Growing Up, 57.

${ }^{45}$ Schiller, "On Naïve and Sentimental Poetry," see part I. 
the "child of nature," which is often expressed in images of children playing happily in pastoral country scenes, such as Runge depicts in Hülsenbeck Children (1805-6) (fig. 2).

A direct line can be drawn from the "child of nature" to the notion of primitivism and the idea of the Noble Savage. Rousseau and others had idealized humanity outside the bounds of civilization, imposing on the "natural" man moral traits that can also be admired in children (innocence, purity). ${ }^{46}$ Parallel to viewing "primitives" as closer to man's natural state, the "child of nature" translated into the "child of man's beginnings" to some artists. Children and their supposed connection to a freer and uncultivated state were viewed as closer to the inherent tendencies of humanity. I demonstrate in chapter two how Klee often returns to a sense of childhood in his art and writings in a way that suggests he desired a return to the primordial state of man.

\section{The Mental States of Children}

The mental processes of children were examined in the modern period and the general findings also added to conceptions of childhood. Understanding childhood scientifically and mapping out its developmental stages meant a wider understanding of human nature that could explain the adult condition. The Swiss psychologist Jean Piaget, for example,

\footnotetext{
${ }^{46}$ Rousseau, Discours, 158. Rousseau held that, in the "wild," all is shared and equal. The writer A. A. Cooper Shaftesbury also promoted the dignified character of an existence unscathed by the artifices of civilization (1710). See Shaftesbury, Soliloquy, or Advice to an Author (1710), reprinted in Critical Responses to Hamlet, 1600-1790, ed. David Farley-Hills (New York: AMS Press, 1997), 32. Shaftesbury suggested individuals should strive "for that simplicity of manners, and innocence of behaviour, which has been often known among mere savages; ere they were corrupted by our commerce." On this issue, see also Michael Newton, Savage Girls, 75; and also Adrianna S. Benzaquén, Encounters with Wild Children (London, Ithaca, Montreal and Kingston: McGill-Queen's University Press, 2006), 34, 45.
} 
researched developing thought processes. ${ }^{47}$ In The Language and Thought of the Child (1926), Piaget identifies a discrepancy between young children's answers and those of older ones. He concludes the former were not less intelligent, but instead answered questions in an unusual manner because they thought differently. ${ }^{48}$ While Klee does not mention Piaget's investigations, I illustrate below the extent to which Klee endeavoured to understand the young mind of his own son, Felix.

Sigmund Freud's work is also notable given its profound influence on conceptions of childhood. In Three Essays on the Theory of Sexuality (1905) and Beyond the Pleasure Principle (1920), for example, Freud presents a counter-current to the "innocent" child and the idyllic "child of nature" by suggesting that sexual awareness develops at an early age. ${ }^{49}$ Freud mapped out various stages of erotic experience babies encounter from oral to anal and genital. ${ }^{50}$ Whether Klee was aware of this discussion or not, he was also interested in children's "inherent” sexualities. In 1911, for example, Klee recorded several of his own childhood memories that are loaded with sexual content. I demonstrate in chapter two how Klee searched for his primal beginnings in part through

${ }^{47}$ See Piaget's highly important and influential theories on children's cognitive development, such as The Language and Thought of the Child (1926) (London: Routledge Classics, 1959).

${ }^{48}$ The Language and Thought of the Child; see also Piaget's The Child's Conception of the World (1929) (London: Routledge \& Kegan Paul Ltd., 1971). Piaget notes that animism (spontaneous life in inanimate things) and artificalism (things in this world are made for people.... a self-centeredness) or magic (myths, etc.) are employed by children when asked about specific things, like dreams, and where babies come from, indicative of their vast imaginations.

${ }^{49}$ Peter Coveney discusses that the idea of innocent children who remained unaffected by adult sexuality died hard in Victorian England and amongst the German Romantics who defended children's sexual innocence. See Coveney, The Image, 300-302.

${ }^{50}$ Sigmund Freud, Beyond the Pleasure Principle (1920); Freud, Three Essays on the Theory of Sexuality (1905), trans. James Strachey (New York: Basic Books, 1962). 
this renewed interest in his sexual nature. ${ }^{51}$

\section{The Wild Child}

In this thesis I will not discuss in depth the connection between children and "primitive" man; I will, however, look specifically at the notion of the "wild child." 52 Wild children or children living without other human contact were "discovered" in Europe from the seventeenth century into the nineteenth. ${ }^{53}$ These children, including Peter the Wild Boy (found in 1725), Victor the Wild Boy of Aveyron (found in 1800), and Kaspar Hauser ("discovered" in 1828) ) (see. figs. 3, and 4), were viewed as exemplars of pure human nature and exemplars of our unfettered origins. ${ }^{54}$ Unlike the Noble Savage, these wild children were regarded by scientists and social scientists as a kind of unknown, primitive other. ${ }^{55}$ Wild children were unsettling because, as children, they had

\footnotetext{
${ }^{51}$ Klee did not refer to Freud in his writings, yet scholars like Tamara Trodd have pointed out affinities between Freud's studies with some of Klee's oil transfers to suggest he was consciously aware of the psychiatrist's work. See Trodd, "Drawing in the Archive: Paul Klee's Oil Transfers," Oxford Art Journal 1, no. 31 (2008): 75-95; Trodd notes that Freud's process of repetition (Project for a Scientific Psychology, 1895), and the process of the mystic writing pad (Notes on the Mystic Writing Pad, 1925), can be examined in relation to some of Klee's oil transfers.

${ }^{52}$ A number of researchers in the late nineteenth century connected children to the "primitive" state of man and compared their pictures with tribal art. Alfred Lichtwark, director of the Hamburg Kunsthallle, linked them in his book Die Kunst in der Schule (1887); James Sully's Studies of Childhood (London: Free Association Press: 1895) relates artistic development in children to the development of "primitive" peoples; and Carl Götze associated them in his catalogue for an exhibition of free children's drawings for the Kunsthalle in Hamburg in 1898 called Das Kind als Künstler (1898), 52.

${ }^{53}$ For discussions of the wild children found in Europe, see Newton, Savage; Douglas Keith Candland, Feral Children and Clever Animals: Reflections on Human Nature (New York and Oxford: Oxford University Press, 1993); and Benzaquén, Encounters with Wild Children, 34, 45.

${ }^{54}$ Rudyard Kipling's The Jungle Book (1895) is a fantastical embodiment of the ideal state of a wild, feral childhood.

${ }^{55}$ See Newton, Savage Girls, 10- 24.
} 
even less control over their drives and impulses and, due to their unsocialized state, had no moral boundaries. ${ }^{56}$ Distinct therefore from the idyllic Noble Savage, these children were viewed by contemporary sources as animalistic. Moreover, these wild children were viewed as connected with other animals in nature and some of the wild children were even found living with them. ${ }^{57}$ I will mainly draw on Edward Dudley and Maximillian E. Novak's edited volume, The Wild Man Within: An Image in Western Thought from the Renaissance to Romanticism and Michael Newton's recent work, Savage Girls and Wild Boys: A History of Feral Children, to inform my discussion of the topic. In chapter two I relate how Klee idealized this wild child experience as unaffected and closer to man's origins, despite its nasty and brutish character. ${ }^{58}$

\section{Spiritual Accessibility in Childhood}

Theologians have long debated the nature of Original Sin and whether it could apply to innocent babes and children. ${ }^{59}$ While there were diverging views, art historian Erika Langmuir argues that, in the nineteenth and twentieth centuries, children were commonly

\footnotetext{
${ }^{56}$ The negative aspects to a wild upbringing have been pointed out by philosophers like Hobbes in Leviathan \{or Commonwealth\} (1651), ed. Edwin Curley (Indianapolis/ Cambridge: Hackett Publishing Company, Inc.: 1994); and by the writer/scientist Benjamin Franklin in Remarks Concerning the Savages of North America, 1784; see also Adrianna S. Benzaquén, Encounters with Wild Children, 163.

${ }^{57}$ See Ch. 2 in Newton, Savage Girls, for a discussion of the children who were found with animals; see also Arnold Gesell, Wolf Child and Human Child (London: The Scientific Book Club, 1942); Hayden White, "The Forms of Wildness: Archaeology of an Idea," in Wild Man Within: An Image in Western Thought from the Renaissance to Romanticism, ed. Edward Dudley and Maximillian E. Novak (Pittsburg: University of Pittsburg Press, 1972), 3-38.

${ }^{58}$ Edward Dudley and Maximillian E. Novak eds. The Wild Man Within; Newton, Savage Girls.

${ }^{59}$ Colin Heywood, A History of Childhood (Malden, MA.: Blackwell Publishers, 2001) 51-53; Erika Langmuir, Imaging Childhood (New Haven and London: Yale University Press, 2006), 41.
} 
viewed as closer to God. ${ }^{60}$ Social historian C. J. Sommerville marks this widespread belief on the ultimate ideal of childhood at the time: children possessed not only "innate knowledge... but an innate goodness" and they had a connection directly to God "until society crushed or corrupted their spirits" (echoing ideas raised in Rousseau's Émile). ${ }^{61}$ Many artists and writers would take up a spiritual view of children, especially the German Romantics. For instance, in his Levana (1807), Jean Paul Richter suggested that children were "messengers from paradise (...) a single child on earth would appear to us as a strange, angelic, super-natural creature." ${ }^{, 62}$ Another example is Runge's use of cherubic imagery, such as in The Great Morning (1809-10) (fig. 5), which relates infant children to mysticism and the mythological. ${ }^{63}$

More recently, the motif of women and embryos that appears in some of Malevich's early works like Woman in Childbirth, (1908) (see fig. 6) relates to the Symbolist interpretation of women and children as the incarnation of a purer state who held a

${ }^{60}$ Langmuir writes: "After all, Christ has been incarnated as a newborn babe; he had later blessed 'little children (...) for of such is the kingdom of heaven/God' (Matthew 19:14; Mark 10:14; Luke 18:15)."

${ }^{61}$ C. John Sommerville, The Rise and Fall of Childhood (Sage Library of Social Research, vol. 140., 1982), 121; for more information on the idea that children were viewed as closer to spirituality, see Rachel Hope Cleves, "Alcott, Bronson," vol. 1, in Encyclopaedia of Children and Childhood in History and Society, ed. Paula S. Fass (New York: Macmillan Reference USA, 2004), 49-50.

${ }^{62}$ Quoted in Colin Heywood, A History, 27; Peter Coveney, The Image of Childhood (Hammondsworth: Penguin, 1967), ch. 3; Robert Pattison, The Child Figure in English Literature (Athens: University of Georgia Press, 1978), ch. 3; Roger Cox, Shaping Childhood: Themes of Uncertainty in the History of Adult-Relationships (London: Routledge, 1996), ch. 4; Sylvia D. Hoffert, Private Matters: American Attitudes toward Childbearing and Infant Nurture in the Urban North. 1800-1860 (Urbana: University of Illinois Press, 1989), see ch. 5.

${ }^{63}$ Richard Littlejohns, "Philipp Otto Runge's Tageszeiten and Their Relationship to Romantic Nature Philosophy," Studies in Romanticism 42, no. 1 (Spring, 2003): 65-74 
mysterious bond to the universe. ${ }^{64}$ In this view, children were pure, associated with spontaneity, pre-existence, and, ultimately, the spiritual realm. ${ }^{65}$ Similarly, a fellow Swiss artist Klee respected, Ferdinand Hodler, depicted children engaged with Nature in a kind of pagan and mystical sense. ${ }^{66}$ Like these artists, Klee also sought out children's connection to a higher source, ideas which I expand upon in this thesis.

\section{Das Kind als Künstler (The Child as Artist)}

Children's art was characterized in the early twentieth century as uncultivated expressions that were natural, objective and true. Many pictures by children found their way into art galleries across Europe for these reasons. Fineberg traces numerous children's art exhibitions from 1898-1950, including: "Das Kind als Künstler” in Hamburg (1898); “Art in the Life of a Child" in Berlin (1901), and "The Art of the Child" in Dresden (1905). ${ }^{67}$ Each of these exhibitions displayed children's art in a way that emphasized their creative imaginations and the resulting work. ${ }^{68}$ Art historian James Smith Pierce has noted that Klee was himself implicated in a children's art exhibition held at the Bauhaus Art Gallery, Dessau, in 1929. ${ }^{69}$

${ }^{64}$ John E. Bowlt, "The Esoteric Culture and Russian Society," in The Spiritual in Modern Art, 168.

${ }^{65}$ Bowlt, "The Esoteric Culture," 168.

${ }^{66}$ Particularly in The Chosen One, Holder links the "child of Nature" to mysticism. The Chosen One will be discussed in more detail in chapter two of this thesis.

${ }^{67}$ Jonathan Fineberg, When We Were Young: New Perspectives on the Art of the Child, (California: Princeton University Press, 2006). Fineberg provides a timeline of children's art.

${ }^{68}$ Fineberg, When We Were Young, timeline.

${ }^{69}$ James Smith Pierce, Paul Klee and Primitive Art (New York: Garland Publishers, 1976); Klee was not directly involved with the show, but the student curator credits Klee with profoundly influencing her on the subject. See also Hans-Friedrich Geist, Paul Klee (Hamburg: Ernst Hauswedell, 1948). Fineberg even suggests that some of Klee's work 
Children's pictures were also investigated to determine how their artistic abilities progressed and to uncover what meanings could be deduced from common forms and motifs. An artistic development study on childhood particularly significant to Klee is the work of a superintendent of Munich primary schools, Georg Kerschensteiner, called Die Entwicklung der zeichnerischen Begabung (The Development of the Gift of Drawing, 1905). In the book, Kerschensteiner drew from over a million children's pictures and published hundreds of samples (see fig. 7). ${ }^{70}$ According to Pierce, Kerschensteiner's study was considered groundbreaking for its postulation that every child passes through artistic, skill-specific stages. ${ }^{71}$ Kerschensteiner focused on how knowledge and the general awareness that comes with age enables children to produce more realistic work realism being something he particularly valued. Scholars like Pierce, Werckmeister, Fineberg, and Franciscono, have established that The Development of the Gift of Drawing likely provided Klee with sources that informed his own work. ${ }^{72}$ Yet, while Klee may have read Kerschensteiner's study, he diverged completely from the superintendent's central argument. Rather than appreciating the realistic representations of older children, Klee valued the visual vocabulary of early ages. As I discuss below, Klee viewed these

could have been inspired by children's pictures included in the exhibition. See Fineberg, The Innocent Eye, 106.

${ }^{70}$ Georg Kerschensteiner, Die Entwicklung der zeichnerischen Begabung (Munich: Gerber, 1905).

${ }^{71}$ In Paul Klee and Primitive Art, Pierce assumes that Klee looked extensively at the children's pictures in Kerschensteiner's study and he actively compares Klee's works to them. Yet Werckmeister points out that Klee never mentioned Kerschensteiner. See Werckmeister, "The Issue of Childhood in the Art of Paul Klee," 42. However, Kerschensteiner's work was immensely popular in Germany and it is possible that Klee had some exposure to them, according to Werckmeister.

${ }^{72}$ This topic is discussed in the literature review of Klee's engagement with childhood in chapter one. See also Kerschensteiner, Die Entwicklung der zeichnerischen Begabung, plate 101. For a comparison of the works, see Franciscono "Paul Klee and Children's Art," in The Innocent Eye, 105-107. 
early years as uncultivated, authentic, and closer to primordial beginnings.

\section{Children and Modern Art}

As these multiple conceptions of children and their art circulated in various intellectual spheres, children's pictures came to represent uncultivated creative faculties and the circumvention of culture and conventional art practice. ${ }^{73}$ Klee's turning to children for inspiration in his own art during the first three to four decades of the twentieth century was anything but a novelty. According to Fineberg, there was a widespread fascination with childhood which reached many modern artists. ${ }^{74}$ Some of Paula Modersohn-Becker's paintings, for example, are naïve and have been linked to a childlike style (see fig. 8 for an example). ${ }^{75}$ Chagall's style reflects an absorption in children's fantasy and Gauguin and the Nabis found authenticity in a return to

\footnotetext{
${ }^{73}$ Primitivism, naïveté, and the less refined was stylistically apart from what was known as "bourgeois materialism" and was a vehicle through which one could achieve a more authentic, innocent, or "natural" perspective. For further information on modern artists and the idea of rejecting convention, see Gill Perry "Primitivism and the Modern" in, Primitivism, Cubism, and Abstraction: The Early Twentieth Century, ed. Gill Perry, Charles Harrison, and Francis Frascina (New Haven and London: Yale University Press, 1993), 3-85.

${ }^{74}$ The information in this footnote is largely indebted to Jonathan Fineberg, "The Postman Did It," in The Innocent Eye, 2-23.

75 The artists of the colony at Worpswede, Germany (from 1892 on), including Modersohn-Becker, achieved "new freedoms" from the constraints of established society in part through a lively interest in the drawings of children. Some of Paula ModersohnBecker's correspondence, for instance, discusses Ottlilie Reyländer's “portfolio[s] of highly original children's drawings" that inspired his work. See Paula ModersohnBecker, The Letters and Journals, ed. Gunter Busch and Liselotte von Reinken, trans. Arthur S Wensinger and Carol Clew Hoey (New York, 1983), 200, 207, 317. In particular, Modersohn-Becker's postcard drawing of 26 July, 1903 has strong naïve qualities. Its flat forms, uncomplicated lines, and crude details resemble a child's artistic skill set.
} 
childhood. ${ }^{76}$ Gustav Klimt, moreover, was attracted to children's pictures and collected them for inspiration in his work. ${ }^{77}$

Many artists of the period have also commented on the creative potential found in childhood. For example, Cézanne stated, "As for me, I would like to be a child” (1904), and Matisse said of himself and Derain that "we were at the time like children in the face of nature and we let our temperaments speak" (1906). ${ }^{78}$ E. L. Kirchner wrote: "The artist is after all the free responsive child, who reacts to each new stimulus" (1928), and Emil Nolde recounted in his diary that he would watch "the work of two young boys (....) drawing with unbelievable skills and full of sparkling life (...) I would stay (...) to grasp it all" (1934). ${ }^{79}$

Der Blaue Reiter, an artistic group that Klee was associated with, enthusiastically endorsed naïve art. Their interest in childhood was expressed in the almanac, especially

\footnotetext{
${ }^{76}$ Fineberg, "The Postman," in The Innocent Eye, 14.

${ }^{77}$ For information on Klimt's interest in children's drawings, see Franciscono, "Paul Klee and Children's Art," in Discovering Child Art, 98.

${ }^{78}$ This information is drawn from Jonathan Fineberg's "The Postman" in The Innocent Eye, 2-28. Fineberg cites Guillaume Apollinaire, Chroniques d'Art (1902-18), ed. L.-C. Breunig (Paris: Gallimard, 1960), 393-94, also quoted in Guillaume Apollinaire, Apollinaire on Art: Essays and Reviews, 1902-1918, ed. L.-C. Breunig, trans. Susan Suleiman (New York: Viking, Documents of 20th Century Art, 1972), 403; for Matisse's quote about himself and Derain, see Gaston Diehl, Henri Matisse (Paris: Pierre Tisné, 1954), 32, quoted in John Elderfield, Henri Matisse: A Retrospective (New York: The Museum of Modern Art, 1992), 52; The quote by Paul Cézanne, "Quant à moi, je veux être un enfant," was first published in Mercure de France (June, 1921), and reprinted in Souvenir sur Paul Cézanne (Paris: Michel, n. d.), 104-5, also quoted in Charles F. Stuckley, "Monet's Art and the Act of Vision," in Aspects of Monet: A Symposium on the Artist's Life and Times, ed. John Rewald and Frances Weitzenhoffer (New York: Harry N Abrams, 1984), 108.

${ }^{79}$ E. -L. Kirchner, E. L. Kirchners Davoser Tagebuch, ed. Lothar Grisebach (Cologne: Verlag M. DuMont Schaubert, 1968), 178, entry of June 1928; Emil Nolde, Jahre der Kämpfre (Berlin: Rembrandt-Verlag, 1934), 180.
} 
in the essay, "On the Question of Form," where Wassily Kandinsky suggests children had direct access to "higher" realities:

Thus in every child's drawing, without exception, the inner sound of the object exposes itself spontaneously (...) There is an unconscious, enormous power in the child (...) which places the child's work on the same level as that of the adult (and often on a much higher one!). ${ }^{80}$

Klee was likely influenced by Kandinsky's view of the spiritual quality found in children's art and he would also share his own views on their artistic abilities in the almanac, comments I discuss in chapter one.

Although his Der Blaue Reiter counterparts shared this child-art interest, Klee's practice was distinct from theirs. Kandinsky had a collection of children's pictures yet, Barbara Wörwag notes, he did not mimic them; he merely synthesized the naïve inspiration in his work. ${ }^{81}$ Marc likewise employed a naïve view in his depictions of animals. ${ }^{82}$ Klee's interest in childhood, however, marks a new and separate approach. As scholars have shown, Klee incorporates the actual schematic devices of children in his work - a childlike aesthetic that is different from the work of his predecessors or contemporaries. Moreover, I demonstrate how Klee used themes of childhood - fantasy, play, and children's connection to nature - to access a childlike sensibility that was highly spiritual in practice.

${ }^{80}$ Wassily Kandinsky, "Uber die Formfrage," in Der Blaue Reiter Almanac, new edition (Munich: R. Piper, 1965), 168.

${ }^{81}$ Barbara Wörwag, “'There is an Unconscious, Vast Power in the Child:' Notes on Kandinsky, Münter and Children's Drawings," in Discovering Child Art, 76.

${ }^{82}$ See Frederick S. Levine, The Apocalyptic Vision (New York and London: Harper and Row Publishers, 1979), 58-75. 


\section{Limits, Aims and Organization}

Relevant scholarship and artistic explorations suggest that childhood was indeed associated with numerous qualities: it is innocent, natural, a key to man's beginnings, animalistic in an untamed form, imaginative, and spiritually connected. In light of these notions, I illustrate how Klee's engagement with childhood was not limited to a formal borrowing of the artistic devices of children. I argue, rather, that Klee's use of childhood was a more meaningful pursuit. The complex character of childhood was explored by the artist in ways that suggest he sought metaphysical, cosmic, and spiritual understanding through a return to his youthful sensibility.

Although I briefly investigate the formal links between the art of children and Klee in the first chapter, this thesis is not primarily concerned with those aspects of his work. These affinities have been examined by the art teacher, Ellen Marsh, and by scholars Pierce and Franciscono. ${ }^{83}$ I do not go into detail about Klee's changing public positions on the connection between childhood and his work, nor will I discuss any further the idea that childhood is a critique of Modern art. These issues have been addressed by $\mathrm{O}$. K. Werckmeister and Robert Goldwater respectively. ${ }^{84}$ Klee's occupation with issues of child violence during the period leading up to the Second World War and the influence of the National Socialists on Klee's view and presentation of childhood have been examined by art historians Josef Helfenstein and Tilman Osterwold. ${ }^{85}$ I only briefly touch on these

${ }^{83}$ Franciscono, "Paul Klee and Children's Art," in Discovering Child Art; Ellen Marsh, "Paul Klee and the Art of Children: A Comparison of their Creative Processes," College Art Journal 16, no. 2 (Winter, 1957): 132-145; Pierce, Paul Klee and Primitive Art, $72-$ 156.

${ }^{84}$ Goldwater, Primitivism in Modern Art; Werckmeister, "The Issue of Childhood in the Art of Paul Klee."

${ }^{85}$ Helfenstein, Josef. "The Issue of Childhood in Klee's Late Work." In Discovering 
views in chapter one. Rather, the focus of this project is on the idea that childhood was something whole and spiritual to Klee. In this pursuit, I refer to Klee's engagement with themes of the "unborn," or the pre-existing state of man, as well as fantasy, play, uninfluenced senses, and the idea of the "wild child."

To inform the basis of my study, I have drawn from the extensive literature on Klee, including the work of Will Grohmann, Herbert Read, Jürgen Glaesemer, Richard Verdi, and Marcel Franciscono. ${ }^{86}$ The most recent publications from the new center in Bern, Switzerland, the Zentrum Paul Klee, have also been consulted. ${ }^{87}$

I also draw on a diverse range of primary source material to inform my project: exhibition catalogues and reviews where Klee's art was likened to children's pictures; personal documents such as diaries that Klee kept from the age of nineteen, along with his letters to friends and family. The artists' published work and pedagogical writings are also significant, especially Creative Credo, lecture notes from The Thinking Eye and The Nature of Nature, and Klee's Pedagogical Sketchbook. First-hand impressions from some of Klee's drawings and watercolours viewed at the Zentrum Paul Klee also contribute to my particular analyses of Klee's works.

Child Art, ed. Fineberg, 122-156; Tilman Osterwold, Paul Klee: Ein Kind träumt sich (Stuttgart: Verlag Gerd Hatje, 1979).

${ }^{86}$ Will Grohmann, Paul Klee: 1879 -1940 (1954) (New York: Harry N. Abrams Inc., 1960); Herbert Read, Paul Klee on Modern Art (London: Penguin Faber, 1966); Jürgen Glaesemer, ed., Paul Klee. Das graphische und plastische Werk (Bern: : Paul-KleeStiftung, 1975); Richard Verdi, Klee and Nature (London: A. Zwemmer Ltd., 1984); Marcel Franciscono, Paul Klee: His Work and Thought (Chicago: University of Chicago Press, 1991).

${ }^{87}$ Richard Hoppe-Sailer, "Genesis and Garden: The Case of 'Inferner Park,", in Paul Klee's Enchanted Garden, edited by the Zentrum Paul Klee, 66-81 (Bern: Hatje Cantz, 2008); Christine Hopfengart, Paul Klee: Hand Puppets, edited by the Zentrum Paul Klee (Bern: Hatje Cantz Publishers, 2006); Dieter Scholz and Christina Thomson, eds., The Klee Universe, text by Christine Hopfengart, Olivier Berggruen, and Peter-Klaus Schuster (The Zentrum Paul Klee, Bern: Hatje Cantz, 2009). 
In each chapter I refer to early twentieth-century conceptions of childhood which I have introduced above. I draw on some histories of childhood, such as the studies by Peter Coveney, Colin Heywood, and Marilyn R. Brown. ${ }^{88}$ These works, along with Anne Higgonet's Pictures of Innocence: The History and Crisis of Ideal Childhood, allow for an informed consideration of historical attitudes towards children. ${ }^{89}$

The temporal parameters for my study are 1920-1931, Klee's years at the Bauhaus. This time frame serves to narrow my inquiry from the artist's invitation to the Bauhaus to the end of his time there and can be divided into three periods: the year of his invitation to teach at the Bauhaus (1920); his years at the Bauhaus in Weimar (1921-1927); and his time at the Bauhaus in Dessau (1927-1931). ${ }^{90}$ I begin with the year of Klee's invitation because, at this time, Klee had already begun to think seriously about teaching. (In fact, he had even attempted to secure a position at the Stuttgart Academy.) ${ }^{91}$ By 1920, after his large solo exhibition at the Goltz Gallery in Munich and the publication his Creative Credo, Klee was formulating the theoretical principles that he would use in the classroom. The period 1920-1931, therefore, allows for a discussion of childhood anchored in the formal and intellectual underpinnings of Klee's professional work that speaks to the seriousness with which he viewed the topic. ${ }^{92}$ It should also be noted that

${ }^{88}$ Coveney, The Image of Childhood; Heywood, A History of Childhood; see also Heywood, Growing up in France; Brown, Picturing Children.

${ }^{89}$ Anne Higgonet, Pictures of Innocence: The History and Crisis of Ideal Childhood (New York: Thames and Hudson, 1998).

${ }^{90}$ Frank Whitford, Bauhaus (London: Thames and Hudson, 1984), 90.

${ }^{91}$ The attempts to secure a position at Stuttgart have been recounted in many letters back and forth from Klee and Oskar Schlemmer in 1919. See O. K. Werckmeister, The Making of Paul Klee's Career (Chicago and London: The University of Chicago Press, 1989), 189-193; For the correspondences about Klee's interest in the post at Stuttgart, see Felix Klee, Paul Klee: A Life and Work in Documents, 187-189.

${ }_{92}$ To explore these ideas fully, I also consider his writings from as early as 1898 , when 
during this time, Klee's work underwent a stylistic shift, as Franciscono suggests. Klee refined his imagery until it bore little direct resemblance to the crude aspects of children's art he had borrowed earlier, though he would continue to employ rudimentary forms with various ironic possibilities through the twenties. ${ }^{93}$ This thesis investigates the concepts associated with childhood found in Klee's art during his Bauhaus years while avoiding his early satirical experiments and the new complexities involved in his late work.

A recurring term I use in this thesis is "childlike" in relation to some of Klee's art. Similar in practice to the reduction of form present in African/Oceania inspired art in line with primitivism, by “childlike” I refer to a style formally reminiscent of children's simplifications - the awkward first scrawls of a child - which is distinct from highly schematized and well developed African carvings, for example. Some modern artists like Klee chose to work with a childlike aesthetic that is often characterized by simplistic forms, broad-brush strokes, and a general shift away from the refined to more elementary forms of expression. ${ }^{94}$

Another term that I use throughout this thesis is "spirituality" - a difficult word to define. Gleaned from the writings of Peter Van der Veer, Lynn Gamwell, and from essays in Maurice Tuchman's exhibition catalogue, The Spiritual in Art: Abstract Painting 1890-1985, the idea of spirituality evokes a sense of mysticism, mythology, the Gnostic, Eastern religions and the occult, and can sometimes refer to Hebrew and Christian

Klee's formal artistic training began; yet the works examined will largely remain within the 1920-1931 parameter.

93 Franciscono, "Paul Klee and Children's Art" in Discovering Child Art; Spiller, The Paul Klee Notebooks, The Thinking Eye, vol. 1, 40; Helfenstein, "The Issue of Childhood in Klee's Late Work," in Discovering Child Art, 122-156.

${ }^{94}$ See Fineberg, The Innocent Eye, for a discussion of artists Kandinsky, Gabriele Münter, and others in connection to a "childlike" style. 
scriptures. ${ }^{95}$ My reference to this concept is based on Klee's particular use of the term.

Klee describes his sense of spirituality with words like "cosmic" and "God." 96

Spirituality was something mysterious and non-discursive to Klee. In his view,

spirituality is a "higher" cosmic force that could be accessed through freely engaging

with his imagination. ${ }^{97}$ It could also be found in uncultivated instincts - or what he

viewed as the intrinsic nature of man. ${ }^{98}$ I use these ideas to argue that Klee's return to his

childhood instincts was a spiritual endeavour.

Rather than being grounded in a particular theoretical framework, my research method takes a social-historical approach that considers contemporary ideologies of childhood in conjunction with the art and writings of Klee. To bridge ideas of childhood with art and spirituality, I examine Klee's work in light of the philosophical, metaphysical and spiritual pursuits common to many modern artists at the time. In part I analyze his iconography to determine links between childhood and the spiritual. More importantly, however, I look at Klee's work that pertains to childhood in order to identify how the artist relates these in his writings to the spiritual.

${ }_{95}$ Peter van der Veer, "Spirituality in Modern Society" Social Research 76, no. 4 (Winter 2009): 1097. Veer's definition reads that spirituality is "the opposite of materiality (...) distinctive from the body (...) distinctive from both the religious and the secular," Lynn Gamwell, Exploring the Invisible: Art, Science, and the Spiritual (Princeton and Oxford: Princeton University Press, 2002); Maurice Tuchman ed. The Spiritual in Art: Abstract Painting 1890-1985 (New York: Abbeville Press, 1986).

${ }^{96}$ For a discussion of the use of spiritual ideas and concepts in Klee' work, see chapter one of this thesis (15-19).

${ }^{97}$ To Klee, art was a process that manifested from the depths of the unconscious and extended to an external cosmic force. In his "Cosmos-Chaos" lecture notes, Klee details the process: starting from an inner thought which moves into a "cosmogenetic moment." These types of metaphysical insights into the act of creation are typical of Klee's pedagogy; see Klee, The Nature of Nature lectures, 63, and Klee's undated lecture note, The Thinking Eye, 66.

${ }^{98}$ See Klee, The Diaries, Diary III, entry no. 944, 1914. 
Chapter one explores Klee's connection to childhood in the existing scholarly literature. In the form of a review, this section discusses the five main contributions to Klee's engagement with childhood: Goldwater's Primitivism In Modern Art; Werckmeister's The Issue of Childhood in the Work of Paul Klee; Osterwold's Paul Klee: Ein Kind träumt sich; Fineberg's exhibition catalogue, The Innocent Eye; and the exhibition's corresponding edited volume, Discovering Child Art, which contains an important essay by Franciscono, "Paul Klee and Children's Art." 99 This review allows for a thorough investigation into how Klee's art has been viewed previously in relation to childhood while, at the same time, clarifying how this project assumes a different perspective. I conclude this section with a novel discussion of Klee's interest in primordial and cosmic beginnings and I relate this to his engagement with childhood. I also introduce the idea that Klee viewed children as the closest beings to this spiritual source.

Chapter two carries over this idea of beginnings to examine Klee's interest in the unencumbered child's vision. Unaffected children, in Klee's perspective, were still connected to man's intended or pre-existing nature and also to spiritual realities. In this discussion, I relate how Klee aspired to view his surroundings as if he knew nothing of modern Europe and its intellectual traditions. Rather, he wished to rely strictly on his senses, a way of processing reality that I argue is similar to an unaffected child's. To illustrate this, I look at works that indicate Klee placed deep meaning in a "wild,"

\footnotetext{
${ }^{99}$ Goldwater, Primitivism In Modern Art; Werckmeister's “The Issue of Childhood in the Work of Paul Klee;" Osterwold, Paul Klee; Fineberg's exhibition catalogue on child-art (The Innocent Eye) and the corresponding edited volume (Discovering Child Art: Essays on Childhood, Primitivism and Modernism); Franciscono, "Paul Klee and Children's Art."
} 
unobstructed childhood. I relate how this return to a sense of his unfettered origins allowed for a kind of spiritual homeland in a "wild" experience.

The aim of chapter three is to examine how Klee's pedagogical philosophy of "play", along with his engagement with fantasy and fairy tales, subscribes to a kind of higher meaning. I illustrate how Klee's playful legacy is both founded on the imaginative play of children and used as a vehicle for the artist to achieve new creative potentials through a cosmic and spiritual connection. ${ }^{100}$ I look to the seminal work, The Uses of Enchantment: The Meaning and Importance of Fairy Tales by Bruno Bettelheim, partly to inform my discussion of the significance of Klee's preoccupation with fairy tales. Especially important are Bettelheim's views that fairy tales are a crucial imaginative exercise for the child's psyche and that they also relate to children the value of a fantastical view of everyday life. I correlate these ideas to Klee's use of fantasy. ${ }^{101}$

In examining Klee accordingly, my research adds to the existing art historical discourse that looks at modern artists' engagement with primitivism and children's art. Particularly this study contributes to an increasing consciousness about the highly complex and spiritual implications in Klee's use of childhood - beyond formalistic comparisons which largely characterize previous inquiries. Furthermore, this examination can potentially open new dialogues in larger discussions of childhood that consider its profound and diverse role in the modern period. For these reasons, I offer a

${ }^{100}$ In terms of fantasy and fairy tales, Klee has been noted for often depicting a "fairytale landscape" and for a general whimsical appeal in some of his work. For example, Helfenstein notes in his article, "The Issue of Childhood in Klee's Late Work" that there is a kind of fairy-tale landscape in Klee's works from the 1920s. See Helfenstein, Discovering Child Art, 144. However, Klee has not been fully explored for his unmistakable interest in the magical world of children's stories.

${ }^{101}$ Bruno Bettleheim, The Uses of Enchantment: The Meaning and Importance of Fairy Tales (New York: Knopf, 1976), 5. 
meaningful re-evaluation of the issue of childhood in the work of Paul Klee. 
Chapter One

\section{"There Will Be Only Fulfillment Of The Beginning, And The Beginning Itself Was Already Fulfillment": Childhood and Paul Klee}

Whoever slept and caught his breath... found his last end in the beginning* Paul Klee

Digging through his parents'storage for frames in 1902, twenty-three-year-old Paul Klee came upon drawings he had created at the age of four, including Lady with Parasol and Horsedrawn Carriage (figs. 9 and 10). ${ }^{1}$ Klee described his childhood works as "the most significant [I have made] until now."2 He wrote that they were "naïve (...) [and] independen[t] from the Italians and Netherlanders" upon which Klee's exhaustive academic training of the preceding four years had been founded. ${ }^{3}$ He was inspired by their imaginative quality and their expressive nature to such an extent that shortly afterwards, Klee rejected the artistic training he had received in Munich and Rome to produce, exhibit and sell countless paintings and drawings that reflect a child's visual vocabulary.

Klee frequently borrowed from his childhood pictures. Klee's childhood Horsedrawn Carriage, for example, can be directly compared to his 1908 A Cart with Two Horses, Just Before Departure (fig. 11). Both compositions employ a similar schematic cart

\footnotetext{
* Paul Klee, The Diaries of Paul Klee: 1898-1918, ed. Felix Klee (Los Angeles: University of California Press, 1964), Diary III, entry 948, 313.

${ }^{1}$ Klee to Lily Stumpf, in Paul Klee, Briefe an die Familie, (1893-1906), ed. Felix Klee (Cologne: Dumont, 1979), 3 October 1902, 272, as quoted in Fineberg, The Innocent Eye, 82; Also quoted in Osterwold, Paul Klee, 6; Werckmeister, "The Issue of Childhood," 139-140.

${ }^{2}$ Klee to Lily Stumpf, Briefe an die Familie, 3 October 1902, as quoted in Fineberg, The Innocent Eye, 82.

${ }^{3}$ Klee to Lily, Briefe an die Familie, 3 October 1902, as quoted in Fineberg, The Innocent Eye, 82 .
} 
motif with wheels made up of X's through the centre. The people and horses are also comparable in the stick-manner in which they are rendered. By contrast, Klee's childhood work is displayed on the two-dimensional plane that begins at the edge of the paper, whereas the cart in the mature work is set back in the distance, as if the scene is being watched from afar, and the figures are placed on a plane that suggests threedimensionality. Other striking examples are Klee's young picture, Child's Drawing, Portraying Five Sisters, which resonates both thematically and stylistically with such later works as A Sick Girl Being Visited by Some Girlfriends, Five Figures (1909), and Five Girls (1910) (figs. 12, 13, and 14). Again, aspects of Klee's adult training can be found in the later works. The shading and positioning of the figures seated on the sofa suggest depth in A Sick Girl, and in Five Girls, the portrait layout and the definition of the faces are quite sophisticated.

Klee's artistic pursuits with respect to childlike sensibilities have been foregrounded in the scholarly literature. The topic has been examined according to five main themes: first, Klee's return to children's art has been linked to the vanguard ideal of primitivism and the rejection of convention; second, Klee's work has been formally analyzed for its affinity with the schematic forms and materials that children use; third, Klee has been recognized for an interest in the unconscious artistic processes of children's picture-making; fourth, Klee's interest in childhood has been presented as a kind of escape from reality; and finally, connections have been made between the theme of child brutality in Klee's late work and WWII. I begin this chapter with a review of the literature organized along these themes. At the same time, I acknowledge where interpretations of his work are lacking. Taking into account these perspectives, I then discuss Klee's $1920 \mathrm{Sol}$ in terms of its 
connection with childhood. I will use Sol to illustrate how the literature on Klee's engagement with children's art can be directly applied to his work. Just as importantly, I will also identify how Sol exemplifies my particular interpretation that Klee employed the vision of childhood as a way to come closer to a kind of higher unity or a spiritual understanding - ideas which have not yet been explored in the existing scholarship.

\section{Connecting Klee to Children and Childhood: The Scholarly Literature}

\section{Children's Art and Primitivism}

In The Making of Paul Klee's Career (1989), O. K. Werckmeister suggests that Klee chose the visual vocabulary of childhood because it was in line with the modern, vanguard ideal of primitivism as a way to remain outside the established canon. ${ }^{1}$ In other words, it was a calculated career decision. While I argue in this thesis that Klee's motives for engaging with childhood involve more than a simple career move, Klee's turning to children's art would indeed have been influenced by primitivism. These ideas have been established in the related literature.

In Robert Goldwater's seminal work, Primitivism in Modern Art, and in the much later work of a similar title by Colin Rhodes, Primitivism and Modern Art, childhood is presented (albeit briefly) as a new paradigm for primitivism. ${ }^{2}$ Goldwater presents certain vanguard artists who endeavoured to peel back the layers of modernity and the "artificialism" of academic training to reach a more authentic vision through a child-like vocabulary. For Goldwater, Klee's work, like Joan Miró's, can be categorized under the

\footnotetext{
${ }^{1}$ Werckmeister, "The Issue of Childhood," 151-188.

${ }^{2}$ Goldwater, Primitivism in Modern Art; Colin Rhodes, Primitivism and Modern Art (London: Thames and Hudson Ltd., 1994).
} 
heading, "Cult of the Child," and he uses Klee's Scene of a Drama (1923) (fig. 15) to exemplify the "childlikeness" Klee often employed in his radical, non-conventional endeavours. Indeed, Scene has the feel of a child's picture in the portrayal of a peaceful, domestic space, in the use of bright colours, and in the application of paint in a flat, loose, and unrefined way.

In a similar vein to Goldwater, James Smith Pierce explores the issue of childhood in Klee's work as one source among others, like folk art, for his reduction of form. Pierce focuses on Klee's work from 1905 through to the end of his life in early 1940 . He connects some of Klee's reductive schemata to the contemporary view that hieroglyphs and children's pictures were similar in as much as both used the essentials of form. ${ }^{3}$ According to Pierce, this interest in the unrefined and the simplistic reveals how Klee wished to cast off the academic mode of representation for something fresh and more spontaneous. ${ }^{4}$

In his discussion of Klee's “childlike” art, Marcel Franciscono significantly connects Goethe's vision of childhood from Faust, in which he equates the uncultivated minds of children with genius, to Klee's 1912 The Child and the Star (fig. 16). ${ }^{5}$ For Franciscono, Klee derived inspiration from children's drawings to regain the worldview or "genius" known to children. This is a literal application of Goethe that applies to the primitive ideal of how unlearned and uncultivated minds were viewed as residing on a higher level than

\footnotetext{
${ }^{3}$ Pierce, Paul Klee and Primitive Art, 140, 155. Pierce discusses how children's use of sign is shared "in the history of civilization with the emergence of writings from simple picture-making," such as the Egyptians.

${ }^{4}$ Pierce, Paul Klee and Primitive Art, 72-156.

${ }^{5}$ Johann Wolfgang von Goethe, Faust: A Tragedy (Leipzig: F. A. Brockhaus, Bayard Taylor, 1881).
} 
those of the educated adult. ${ }^{6}$

\section{Klee's Use of Children's Methods and Schematic Forms}

Klee has been meticulously analysed for formal comparisons between his work and that of children. Pierce, for example, goes to great length to relate Klee's motifs to what he calls the "key schematic devices" typical of children's drawings: their use of the flat and two dimensional; exaggeration of the characteristic aspects of objects; their employment of rudimentary shapes, different types of scribbling, and so on. ${ }^{7}$ This suggests just how far Klee perhaps went to mimic stylistically drawings from an early phase in life. Moreover, O. K. Werckmeister has shown in "The Issue of Childhood in the Work of Paul Klee" that Klee's artistic borrowing from children's pictures was likely informed by images he saw in the pioneering study of children's art, The Development of the Gift of Drawing, published in 1905 by the superintendent of Munich schools, Georg Kerschensteiner. ${ }^{8}$ Werckmeister pays particular attention to a child's depiction of a snowball fight from Kerschensteiner's book and compares it with Klee's 1913 Human Helplessness (figs. 17 and 18). ${ }^{9}$ Klee's rendering of the torsos in the form of two stacked triangles, one inverted, in Human Helplessness, and the linear web on which he laid the figures indeed seem directly

\footnotetext{
${ }^{6}$ Franciscono, "Paul Klee and Children's Art," in Discovering Child Art, ed. Jonathan Fineberg (Princeton: Princeton University Press, 1998), 104; This discussion is also found in Franciscono, "Paul Klee's Lithographic Drawings of 1912: Some Unsuspected Illustrations of 'Faust,"' Pantheon 41, no. 1 (January - March, 1983): 34-38.

${ }^{7}$ Pierce, Paul Klee and Primitive Art, 72-156; For a late-nineteenth century work on what characteristics are found in children's drawings, see Corrado Ricci, L'arte dei Bambini (Bologna: Nicola Zanichelli, 1887), 304-305. Ricci studied what children drew in their art, concluding that children's pictures symbolize objects: for example, they try to reproduce people in their "literal completeness, and not according to visual perception."

${ }^{8}$ Werckmeister, "The Issue of Childhood," 141-143.

${ }^{9}$ For a comparison of these two works, see Franciscono "Paul Klee and Children's Art,"
} 
inspired by the child's work. What Werckmeister fails to observe is the meaningful existential notion conveyed by the title, Human Helplessness. Klee implies ironically through a child's vocabulary that humans are subject to higher forces of destiny, a theme that is absent from the child's picture.

More recently, Fineberg has similarly pointed out that the methods Klee used are reflective of those employed by young children. For example, Fineberg observes that Gate in the Garden of 1926 (fig. 19) has a child's finger-painted quality and, at the same time, consists of layers of scraped back wax crayon to form colourful images, recalling a rudimentary technique from kindergarten. ${ }^{10}$

\section{Klee and the Processes of Children's Picture Making}

Klee's desire to consciously mimic an unconscious state known to children in their art making has also been examined in the scholarly literature. In the mid 1950s, for instance, art teacher Ellen Marsh draws from developmental studies on children, such as Rudolf Arnheim's Art and Visual Perception (1954), and contemporary children's drawings to analyze Klee's work. ${ }^{11}$ Children, Marsh observes, see colour and objects with a sense of immediacy and have a natural desire to capture their surroundings in pictures. ${ }^{12}$ Since Klee's writings indicate he searched for a kind of inner creativity, it was this unconscious sense, Marsh argues, that attracted Klee to children's pictures. ${ }^{13}$ Although Marsh's

105-107.

${ }^{10}$ Fineberg, The Innocent Eye, 88-93.

${ }^{11}$ Ellen Marsh, "Paul Klee and the Art of Children: A Comparison of Their Creative Processes," College Art Journal 16, no. 2 (Winter, 1957): 132-145; Rudolf Arnheim, Art and Visual Perception (Berkeley: University of California Press, 1954).

${ }^{12}$ Marsh, "Paul Klee and the Art of Children," 133.

${ }^{13}$ Marsh, "Paul Klee and the Art of Children," 133. 
methodology of applying contemporary child-psychology to Klee's pictorial engagement with childhood is problematic from a historical perspective, the conclusion is well noted: Klee's work relentlessly reveals "revelations of adult sophistication," beyond a child's capability, which truly separates his work from the subjects of his inspiration. ${ }^{14}$

In addition, Goldwater argues that Klee's conscious attempt to regain a childlike sensibility was achieved through "intellectual realism."15 This method differs from visual realism because it emphasizes or exaggerates the most important features of an object, a technique in picture-making that children are known to employ. ${ }^{16}$ Yet, like Marsh, Goldwater is clear in his point that Klee's motives in employing children's devices were highly purposeful and intellectual, and the artist could not in practice shake off his adult sensibility. ${ }^{17}$ Thereby Klee's motifs and forms that resemble children's are combined with more sophisticated modes of representation, reflexive of the deep thought processes behind them.

\section{Childhood As Escape From Reality}

In 1979, Tilman Osterwold curated an exhibition devoted to Klee and childhood: Paul Klee: Ein Kind Träumt sich. For Osterwold, childhood was the "essence of the search for Klee's own identity" as an artist. ${ }^{18}$ Osterwold's exhibition and corresponding catalogue maintain that Klee's goal in exploring children's art was to achieve a sense of the naïve

\footnotetext{
${ }^{14}$ Marsh, "Paul Klee and the Art of Children," 133.

${ }^{15}$ Goldwater, Primitivism in Modern Art, 197.

${ }^{16}$ Goldwater, Primitivism in Modern Art, 197.

${ }^{17}$ Goldwater, Primitivism in Modern Art, 199-204.

${ }^{18}$ Osterwold, Paul Klee, 6.
} 
and the dreamlike state of childhood. ${ }^{19}$ Many instances of Klee's engagement with childhood are presented here: Klee's interest in his own youthful pictures; his fascination with the drawings of his young son, Felix; the puppets Klee made for Felix; "childlike" pictorial aspects to his style; and the recurring subject of childhood in his work in general. Examining Klee's late work, Osterwold argues that the artist retreated into the "world of the child" due to increasing desperation in social and political spheres related to the National Socialists in Germany. ${ }^{20}$ What is problematical in Osterwold's study is the use of the terms "dream" and "dreamlike state of childhood," because, as I will later explore, it is not clear in Klee's writings that he necessarily wished to return to a dreamlike reality. Rather, Klee appreciated the unchecked creativity achieved in children's pictures and the way they enabled him to encounter his surroundings with more attention and, as I later argue, with a more spiritual cast of mind.

\section{Child Art and War}

While Klee's art beyond 1931 exceeds the scope of this thesis, it is important to note the work of Josef Helfenstein, who analyzes Klee's late engagement with childhood related to "the dangerously increasing gravity of political events in Germany and Europe, as well as to the existential questioning of his artistic self that these events stimulated." ${ }^{21}$ Helfenstein looks at a variety of critical issues Klee presents in his work that relate to the Nazis and, especially, Nazi treatment of children. One example is the appearance in Klee's work of what he calls "adult 'instructive' violence" which occurred in primary schools

\footnotetext{
${ }^{19}$ Osterwold, Paul Klee, 8.

${ }^{20}$ Osterwold, Paul Klee, 96, 123.

${ }^{21}$ Helfenstein, "The Issue of Childhood," 122.
} 
under the abusive Nazi-education programs. Such programs encouraged hate and violence and in this discussion Helfenstein refers to works like The Game Degenerates (1940) (fig. 20), where a child's game transforms into mass psychosis and group violence.

Werckmeister has interpreted this type of iconography as indicating that Klee revised his attitude towards children's art and childhood from 1933 onwards to one of growing pessimism. This, he argued, was due to the negative criticisms of his work as unsophisticated and simplistic, and the Nazi threat of being labelled degenerate. ${ }^{22}$ Helfenstein challenges this position since it ignores the fact that Klee continued to present children in a positive light, despite these weighty images of child violence, in addition to the fact that Klee continued in his last years to pursue a childlike aesthetic. ${ }^{23}$ Klee's sometimes negative presentation of childhood, Helfenstein concludes, reveals how the political upheavals at the time affected Klee in a highly personal way given that ideas of childhood leading up to this period held an intimate place in his oeuvre. It is precisely this period when childhood was an "intimate" topic for Klee - from1920-1931 - that will be the focus of this thesis.

\section{An Examination of Sol}

The literature on Klee's connection to childhood is quite comprehensive: it has focused on Klee's work as influenced by practises of primitivism and on the formal properties of Klee's schematic style; it has located children's sources for his work; and it has set his art within a socio-political context. An examination of Klee's 1920 drawing Sol (fig. 21) will allow for both a recapitulation of these issues and a means to establish my own insights

${ }^{22}$ Helfenstein, "The Issue of Childhood," 140. 
into Klee's engagement with childhood.

\section{Sol and Childhood}

In Sol we find something of the earnest and commonplace vision of children's drawings. A very simplified and childlike sun presides over a train track that consists of parallel lines occasionally crossed with horizontal ones. A box-like and two-dimensional locomotive speeds across these lines. Cables and power lines composed of lines and dots take over the left side of the visual plane. On closer observation, the track is a musical staff and the engine's emissions transform into notes. Immediately, Sol is reminiscent of a child's picture because the motifs and themes of children's drawings are mostly those of their familiar surroundings: sun, sky, and vehicles, especially locomotives. ${ }^{24}$ Klee was aware of the importance of trains to some children, noting in his diary how his son was particularly thrilled by them. ${ }^{25}$ The way the sun is labelled by name ("sol") may also hark back to a child's early learning method of associating precise language with objects. Sol appears harmonious and the childlike subject matter presents a certain freshness to the viewer, a freshness Marsh described as a child's immediacy in his/her surroundings, which Klee was no doubt intending to capture. ${ }^{26}$

Because Klee had access to a wealth of children's pictures in Kerschensteiner's study, as Werckmeister has pointed out, it is reasonable to look for possible similarities from this

${ }^{23}$ Helfenstein, "The Issue of Childhood," 140.

${ }^{24}$ Kerschensteiner, Die Entwicklung der zeichnerischen Begabung, pl. 10.

Kerschensteiner looks at children's depictions of locomotives and notes that it was a popular motif for children.

${ }^{25}$ Klee, The Diaries, Diary I, from June to October, 1909, 424. 
source with reference to Sol. The flat wheels of the train - circles with X's through the center - for instance, are directly comparable to children's wheels in Kerschensteiner's work (see fig. 22 for an example). Moreover, drawings by two eight-year-old children illustrated in Kerschensteiner's book show power lines highly similar to Klee's (fig. 23, nos. 5 and 6). Both have the long vertical line of the main pole, with multiple horizontal lines at the top. Klee's power lines emit lines with dots. Dots, to Klee, were potentials of energy and lines express the movement of different types of energy. ${ }^{27}$ Perhaps these lines with dots refer to electricity invisible to the eye, which is also present in the children's renderings of power cables that show lines with dots or in their use of zigzag forms.

\section{Seeking Out Beginnings: Ideas of Childhood in Klee's Writings}

As scholars have pointed out, Klee's personal and pedagogical writings express a deep fascination with childhood. In a 1902 diary entry, not long after he re-discovered his childhood pictures, Klee established a personal allegory for his artistic production: the birth of children.

My husband gave me a child, that is, it came by itself, as children will. It takes after me and is quite gifted. It is good in geography and has many other talents. It will certainly become a great artist. I hate all people who say something that sounds critical about my child. I take it personally. I only want to hear flattering things. My child is a lucky child. What failed in my life will succeed in its life. All it does, suits it. I find it beautiful (...) there is nothing higher $(. . .)^{28}$

In direct opposition to early modern artists reference to their work as "machines," Klee sensitively viewed his output as a baby or collectively as his children. ${ }^{29}$ In viewing his

${ }^{26}$ Marsh, "Paul Klee," 133.

${ }^{27}$ Klee, Pedagogical Sketchbook (New York: Praeger Inc., 1960), section I. 1-16.

${ }^{28}$ Klee, The Diaries, Diary III, entry 442, 1902, 127-128.

${ }^{29}$ Émile Zola, for example, has his characters use the term "machine" frequently in reference to their work. These examples are reflective of the modern art scene at the 
product in this way, Klee also indicates a desire to give his work a kind of ultimate meaning that mimics the act of Creation itself. ${ }^{30}$

More than this metaphoric view of his art as his children, Klee expresses that he would like to bring back a kind of authenticity in his work which can also be linked to childhood. In a manner that draws from a German Romantic tradition, Klee longed to reincorporate a naturalness in his art that was unaffected. In 1906 he wrote: "the notion of 'study' is a thing of the past. Everything shall be Klee." ${ }^{31}$ In another entry, Klee posed the question to himself: "Do you like nature?" 32 He replied to this: "Yes, my own." 33 This desire to return to an inherent artistic expression was played out in a return to childhood. From 1911, Klee was associated with Der Blaue Reiter artists like Wassily Kandinsky and Franz Marc who not only shared in this longing for originality, but had an appreciation of reducing form to the essentials. ${ }^{34}$ Klee's search for the "primordial origins of art" was found in children's artistic vision. In the Blaue Reiter almanac, Klee suggests they should be taken seriously:

For there are primordial beginnings in art, which one is more likely to find (...) at home in the nursery (...) Do not laugh, reader! Children also have artistic ability, and there is wisdom in their having it! The more helpless they are, the more instructive is the art they offer us; for there is (...) a corruption (...) when children begin to absorb developed works of art or even imitate them (1911). ${ }^{35}$

time. See Zola, L'oeuvre (Paris: G. Charpentier et C. Éditeurs, 1886).

${ }^{30}$ Klee has been recognized for viewing his artistic production as replicating Genesis and Creation. See Christian Geelhaar, Paul Klee and the Bauhaus (New York: New York Graphic Society Ltd., 1973), 26; See also Richard Verdi, Klee and Nature (London: A. Zwemmer Ltd., 1984), 94.

${ }^{31}$ Klee, The Diaries, Diary III, entry 757, February 1906, 197.

${ }^{32}$ Klee, The Diaries, Diary III, entry 681, 1906, 185.

${ }^{33}$ Klee, The Diaries, Diary III, entry 681, 1906, 185; See also Diary III, entry 757, February 1906, 197.

${ }^{34}$ Mark Roskill, Klee, Kandinsky, and the Thought of Their Time: A Critical Perspective (Urbana and Chicago: University of Illinois Press, 1992), 34.

35 According to Werckmeister, this quote is quoted in the introduction to the Blue Rider 
Werckmeister has remarked that this entry indicates Klee viewed children's pictures as windows to the primitive beginnings of man. ${ }^{36}$ However, Helfenstein observes that Klee interpreted "primitive" not entirely in the ethnographic sense, but as a desired new beginning of artistic development. ${ }^{37}$ To Klee it was not some outside "other" upon which he could base the source of his artistic beginnings, but right "at home in the nursery." Moreover, Klee's use of the term "primordial," a word that signifies origins such as the beginnings of a solar system or the universe, is significant. ${ }^{38}$ Klee relates this concept of beginnings directly to children, indicating that children and the first beginnings of the universe are linked. In this way, children possess "wisdom" and are "instructive."

In the same year as the almanac was released, Klee added thirty-six written accounts to the very front of his diaries, called "memories of childhood." 39 Presumably Klee believed such memories stood closer to a primordial sensibility which was impetus enough for him to go back and include them. Fineberg relates that Klee's recording of these memories signifies he saw the importance in all he could identify with the mind of his childhood. ${ }^{40}$ However, Fineberg does not consider how the individual recollections can inform us about what Klee wished to gather from his youthful days. For one "memory," Klee wrote:

When grownups were talking (...) I wasn't able to catch individual words out of the swift flow of sentences. Endless sentences without meaning, like a foreign language

almanac. See Werckmeister, "The Issue of Childhood," 138-140; also quoted in Paul Klee, Schriften, Rezensionen und Aufsätze, ed. Christian Geelhaar (Cologne, 1976), p. 97. ${ }^{36}$ Werckmeister, "The Issue of Childhood," 138.

${ }^{37}$ Helfenstein, "Childhood in Klee's Late Work," 147-148.

${ }^{38}$ According to the Merriam-Webster Dictionary, "Primordial" means "first created or developed" and "existing in or persisting from the beginning like a primordial gas cloud." See Merriam-Webster Online Dictionary, "Primordial," http://www.merriamwebster.com /dictionary/primordial.

${ }^{39}$ Klee, The Diaries, "Memories From Childhood," 3-13.

${ }^{40}$ Fineberg, The Innocent Eye, 83. 
(very early memory; two to three years). ${ }^{41}$

The memory communicates an understanding of a kind of pre-language state that Kleethe-child experienced. Klee could not conceive of adult reality at his young age because adults had moved away from their own "inherent" natures. Perhaps it is precisely this prelanguage that Klee was attempting to regain in Sol, one that is unchecked and primordial. However, the beginnings of adult language is conveyed in Sol in the labelling of the sun, reflective of the idea that children will inevitably move away from their child senses and "begin to absorb" adult manners which, to Klee, was a source of "corruption."

\section{Pedagogical Writings and the Influence of Children's Art}

Since he created the work just as he was sorting out an approach to teaching, Sol provides a formal and explicitly semiotic example of Klee's engagement with childhood. Klee's summons to the Bauhaus (1920) was the beginning of a new era for the forty-twoyear-old artist which required of him to develop and elaborate on a theoretical system underlying his art process. He reported: "When I came to teach I was obliged to make precisely clear to myself what I did for the most part unconsciously." ${ }^{42}$ What is noticeable about Klee's theoretical writings and lecture notes is the fact that he largely left out direct references to childhood. This discrepancy is discussed critically by Werckmeister who holds that Klee shifted his dialogue about the creativity of children strategically to avoid the negative criticism he sustained in regards to being simplistic and "infantile." 43 While this may be the case, Klee's fundamental ideas about purity of form and inner creativity

\footnotetext{
${ }^{41}$ Klee, The Diaries, "Memories from Childhood," no. 3, 3.

${ }^{42}$ Klee, quoted in Frank Whitford, Bauhaus (London: Thames and Hudson, 1984), 41.

${ }^{43}$ Werckmeister, "The Issue of Childhood," 176.
} 
are inspired by his fascination with children's art, ideas I will discuss in relation to Sol.

From 1920-1931, Klee would formulate formal principles related to a modern aesthetic that emphasized simple forms and basic techniques, practices that are reminiscent of the art of small children. Klee lectured his students: "the level of the elementary creative process must be kept tacitly in mind" in artistic production. ${ }^{44}$ Basic forms, such as lines, dots, and simple shapes, were presented in detail by the Bauhaus Master to be vital in composition building, forms that make up Sol's formal presentation for example. In Klee's Creative Credo, published the year Sol was executed, Klee states "the purer the graphic work, that is, the more emphasis placed on basic formal elements, the less wellsuited it will be to the realistic representation of visible things." ${ }^{45}$ By using fundamentals in art, one could move away from the representational or "visible" world and into what Klee considered a more creative and truthful depiction of reality. This implies that, by "returning" to common elements of the "instructive" art of children, one can arrive at a kind of representation that is new and whole.

This interpretation is confirmed in Klee's lectures that discuss the importance of finding one's creative source through an interaction between an inner imagination and the outer visible world. He states: “(...) the indissoluble unity of the world within and the world without is completed in the eye."46 Marsh discusses this quote in relation to the way children create. Children effortlessly combine an "inner" creative imagination with their

\footnotetext{
${ }^{44}$ Klee, The Nature of Nature, lecture notes, 385.

${ }^{45}$ Paul Klee, "Creative Credo" (1920) in The Inward Vision, ed. Carola Giedion-Welcker, et al., trans. Norbert Guterman (Cologne: Verlag M. DuMont, 1958), 10-11.

${ }^{46}$ Marsh, "Paul Klee," 144; and Werner Haftmann, The Mind and Work of Paul Klee (New York: Praeger, 1954), 161.
} 
conception of outer reality. ${ }^{47}$ Accessing this creative source can be achieved by focusing on "the act of forming rather than form itself, form in the process of growth, as genesis, rather than as the ultimate appearance."48 By encouraging his students to view their work as a creative process - not as a means to an end - Klee also indirectly refers to children's artistic processes. This ability to remain captivated in the present moment is an ideal quality of the naïve or childlike artist/poet according to the German Idealist writer, Schiller. Remaining conscious of our present senses, and treating the moment with attention, Schiller tells us, will help to develop a formal artistic impulse that is authentic, naïve and creative. ${ }^{49}$ Klee may indeed be referencing this notion of naïve, childlike presentness.

Klee values the use of line above all other modes of creation. Pierce has influentially discussed Klee's use of line in detail as a process he shared with children since lines are one of the simplest methods of seizing an object. ${ }^{50}$ Children typically use lines to represent things by their contour or their outer shell, according to Pierce, as in their early stick-form depictions of people. ${ }^{51}$ There are other reasons, however, that Klee's use of the line has affinities with childhood. According to Klee, lines have certain energy, are indicative of the abstract, and also characterize something of an object's essence to

\footnotetext{
${ }^{47}$ Marsh, "Paul Klee," 144.

${ }^{48}$ Klee, The Nature, lecture notes, Tuesday, 27 November, 1923, 43; See also notes of the same year on p. 67.

${ }^{49}$ Schiller, Letters on the Aesthetic Education of Man, 65-67; see also Schiller, "On Naïve and Sentimental Poetry," part 1, 17. Schiller states that "the naïve is childlikeness, where it is no longer expected" and if one can find pleasure in nature and appreciate its "inner necessity," one can has truly achieved a childlike sensibility.

${ }^{50}$ Pierce, Paul Klee, 90.

51 Pierce, Paul Klee, 85.
} 
represent it as a living thing or solid object. ${ }^{52}$ In this way, lines reveal qualities of the depicted object's nature, imparting something unseen in the form represented. Moreover, in his The Nature of Nature lectures, Klee relates the importance of achieving movement in form through lines because movement expresses uniqueness and achieves a creative flow. ${ }^{53}$ Klee states further that movement is expressed in its most pure state in straight, wavy, or zigzag lines. Interestingly, straight, zigzags and wavy lines are often playfully present in children's drawings to suggest activity and movement. In the example from Kerschensteiner's book (fig. 23), children drew power lines (no. 6) with zigzag and wavy lines to imply unseen energy and electricity. Similarly, the lines representing sun rays in Sol that rotate clockwise represent the energy, light and warmth the sun provides to the scene, and the lines with dots emitted from the power cables may refer to the electromagnetic energy surging through them, qualities of our surroundings that are not actually visible. Expanding on Pierce's suggestion, the preferential status Klee gave the line and its symbolic representation of invisible energy is another way Klee connected to a childlike vision.

Ultimately this interest in a child's vision can relate to Klee's well-known artistic conviction: "art does not reproduce the visible; rather it makes visible." ${ }^{, 54}$ Indeed, Klee's formal writings suggest the artist strove for the endless artistic possibilities in elementary methods of creation (lines, basic shapes, inner creativity, and a focus on the present moment) to "make visible" a kind of abstract and childlike reality.

${ }^{52}$ Klee, Pedagogical Sketchbook, 16-17, 48-49.

${ }^{53}$ Klee, The Nature, notes, December 4, 1923, 87; In lecture notes from The Nature, Tuesday 27 November, 1923, 51, Klee also discusses sounds that wave-like and zigzag lines radiate.

${ }^{54}$ Klee, "Creative Credo," 5-11. 


\section{Complexities in Sol}

Although engaged with childhood, Sol reveals Klee's profound knowledge and experience which genuinely separate his work from the subjects of his inspiration. In Sol, Klee displays forms in seemingly three-dimensional space; for example the power lines, which add a certain complexity and suggests an intellectual understanding of space that is beyond a child's ability. The tracks and power cables recede into the distance and cut between dimensional realities onto the two-dimensional plane, indicating a complex understanding of perspective.

Additionally complex are the musical references in the work, pointed out by David Burnett and Mitchell Frank. ${ }^{55}$ Frank has shown that a score of a Bach sonata translated into a Bauhaus lecture by Klee corresponds to the musical notes emitted by the train's engine. ${ }^{56}$ Burnett tells us "the entire work seems to hum through space" between the power lines, the musical engine exhaust, and the sun labelled sol, but also the fifth note of the diatonic scale. ${ }^{57}$ Moreover, given that Andrew Kagan has shown that Klee was indeed aware by 1920 of Johann Joseph Fux's work, I would add that Klee refers to Fux's Gradus Ad Parnassum, an eighteenth-century textbook on musical counterpoint, in Sol. ${ }^{58}$ Fux

\footnotetext{
${ }^{55}$ For information on Klee and music, see Hugo Düchting, Paul Klee: Painting Music (Munich: Prestel, 1997); and Andrew Kagan, Paul Klee and Music (Ithaca, New York: Cornell University Press, 1983). Musical references can be expected in Klee's work considering Klee was an accomplished violinist, having performed at concerts as a child. Music remained an influence in his art, as revealed with Sol.

${ }^{56}$ Mitchell B. Frank, "Sol," in Central European Drawings from the National Gallery of Canada, ed. Mitchell B. Frank and Erika Dolphin (Ottawa: National Gallery of Canada, 2007), 164.

${ }^{57}$ David Burnett, Hommage A Paul Klee: 1879 - 1940 (Ottawa: National Gallery of Canada 1979), 34; Frank, "Sol," in Central European Drawings, 164-165.

${ }^{58}$ Johann Joseph Fux, Gradus ad Parnassum (1725) (New York: Broude Brothers, 1966);
} 
presents a summary of Musica Speculativa (the analysis of intervals as proportions between numbers) which describes "music of the spheres" or the idea that notes bridge different realities to achieve metaphysical harmony. ${ }^{59}$ Similar to how Burnett describes Sol as humming, Klee could refer to how different realms ring with sound where music oscillates between the electrical/magnetic (power lines), the earthly/terrestrial (the train), and the solar/atmospheric/heavenly (sun). Although the artist did not use colour in Sol to hint at musical notation as he does in Ad Parnassum (1931), Klee schematically drew clear musical forms to depict a Gradus Ad Parnassum notion of a unifying and harmonious sound permeating all spheres, resounding even on a cosmic level.

These musical references relate also to Sol's childlike vocabulary. In his diary, Klee connects his work to the "voice" of the child:

To invent the chorus mysticus which would have to be performed by a few hundred children's voices. He who were able to do that would not need to exert himself. The many little works ultimately lead there (1914). ${ }^{60}$

Broadly this quote relates how Klee's musical interests aid him in expressing a kind of mysticism in art, an idea he sought to exploit through the "voices" of children. In this way, Klee would not need to strive over and over again for a sense of originality or creativity. He would simply arrive there through a return to his childhood instincts. More specifically, this quote relates to the iconography of Sol. The strong musical connections in Sol (the note "sol," the music staff for a track, and buzzing power lines) seem to offer a

Andrew Kagan, Paul Klee: Art and Music (Ithaca and London: Cornell University Press, 1983), 41-52. Kagan argues that it was in 1920, when Klee was starting to think more formally about his artistic practice, that he returned most fundamentally to the musical counterpoint outlined by Fux's Ad Parnassum.

${ }^{59}$ See Johann Joseph Fux, Gradus Ad Parnassum, quoted in Kagan, "Paul Klee's Ad Parnassum: The Theory and Practice of Eighteenth-Century Polyphony as Models for Klee's Art,” Arts Magazine LII (September, 1977), 90-104. 
kind of children's chorus - it rings with sound conveyed through a child's artistic vocabulary. The relationship between childhood and music in Sol, along with a connection to a Gradus Ad Parnassum notion, suggests a link between children and a cosmic or mystical realm. Indeed, Sol presents a chorus mysticus, and is a unique and powerfully imaginative form of expression achieved through the "primordial" "voices" of children.

In 1916, Klee sighs: "What a weighty destiny: to be the hinge between this side and the other side, a hinge at the border." ${ }^{, 61}$ Sol also relates this idea of existing between worlds. The unmistakably prominent electrical pole in Sol that is buzzing with energy can be read as an axis mundi, a world pillar that bridges the human-perceived world with metaphysical and heavenly realms. Moreover, the iconography in Sol could refer to Van Gogh's spiritual train. Klee was deeply fond of Van Gogh and recorded in his diary that he read the artist's letters, which were published posthumously. ${ }^{62}$ In a particularly moving correspondence to his brother, Van Gogh wondered why we cannot take a train to "reach a star," to cross between terrestrial realities into the celestial "while we are alive.,"63

Considering the multiple connections in Sol to the metaphysical, the train in Sol may

${ }_{61}^{60}$ Klee, The Diaries, Diary II, entry 933, summer of 1914, 319.

${ }^{61}$ Klee, The Diaries, Diary III, entry 957, 1914, 315-316.

${ }^{62}$ Klee respected Van Gogh and notes that he read the artist's letters. See The Diaries, Diary III, entry 258, 1911, 259.

${ }^{63}$ In a letter to his brother Theo, Vincent writes: "Why, I ask myself, should the shining dots of the sky not be as accessible as the black dots on the map of France? If we take the train to get to Tarascon or Rouen we take death to reach a star. One thing undoubtedly true in this reasoning is this: that while we are alive we cannot get to a star, anymore than when we are dead we can take the train. So it seems to me possible that cholera, gravel, phthisis and cancer are the celestial means of locomotion, just as steamboats, omnibuses and railways are the terrestrial means. To die quietly of old age would be to go there on foot," see Vincent van Gogh, Complete Letters of Vincent Van Gogh, vol. 1 (Boston, New York, London: Bulfinch Press, 2000), letter 67, summer of 1888, 57- 
indeed be en route to a divine realm. It is unlikely that Van Gogh's train was Klee's inspiration for Sol, but Klee nevertheless expresses philosophical and spiritual ideas in the work through a childlike vocabulary or through "the voices of children."

\section{The Spiritual in Childhood}

As I have shown, Werckmeister focuses on Klee's engagement with childhood as a crafty and timely pursuit, and Pierce studies Klee's reduction of form in line with Modernist ideals. Fineberg takes a general approach to the topic where he finds connections to childhood in Klee's writings and materials, and Helfenstein looks at the issue of childhood in Klee's work in relation to war. The existing literature, therefore, leaves out the cosmic and spiritual possibilities related to Klee's connection to childhood, as exemplified in works like Sol. Some scholars prefer to leave out these philosophical interpretations. In fact, Franciscono maintains that Klee's intention was to play on reality in an ironic and witty manner. ${ }^{64}$ This view is problematical given it does not withstand the strong evidence of the artist's valuing of the mystical unseen forces and alternate realms.

Klee's artistic purpose was ultimately aimed at bringing him closer to the mysteries of the universe. From as early as 1915 , Klee reported that he wished to be an artist "anchored in the cosmos." "65 In this way he would be "a stranger here [on Earth]" but it would make him, "strong" and "[would] be the final goal." "66 As a Bauhaus Master, Klee's lectures and pedagogical work would take on an increasingly explicit connection to ultimate things like God and Creation, a new meaning that was perhaps inspired by the

58.

${ }^{64}$ Franciscono, Paul Klee: His Work and Thought, 262-263.

65 Klee, The Diaries, Diary III, entry 421, 1902, 122. 
demands of the lecture hall where the artist was forced to think about the ultimate purpose of his art and practice. ${ }^{67}$ In 1922, for example, he lectured that, in the act of creation, artists should "operate with a cosmic consciousness." 68 The professor also encouraged his students to create in a "a synthesis of outward sight and inward vision" and in "the image of God's work."69 Similar, therefore, to the manner in which Klee viewed his own work as his "children," he encouraged his students to think of their work as this ultimate act of Creation. Moreover, Klee asks of his students to press towards the mystery of the orientation in pictorial space, through which one will encounter a "cosmic bond that descends from above" to the "eye of the artist" below. ${ }^{70}$

Parallel to this existential and spiritual aspect of his artistic process, Klee would seek out the work of children at an unprecedented rate in his years as a professor. Franciscono has observed that the simplicities of children's art had great attraction to Klee in the 1920's, more so than they had held for him earlier. ${ }^{71}$ In practice, therefore, Klee combined his formal teachings that emphasized a connection to the cosmos and a kind of consciousness that supersedes earthly phenomena to a heightened interest in childhood, children's art and a child's vision.

The entwined nature of these two topics in Klee's pedagogy can be more fully established through a classroom discussion of 1922. Klee stated: "Man is not complete.

One has to keep in development, be open, also in life, be a child on another level, child of

${ }^{66}$ Klee, The Diaries, Diary III, entry 421, 1902, 123.

${ }^{67}$ Klee, Paul Klee: The Thinking Eye. The Notebooks of Paul Klee Volume 1, ed. Jürg Spiller, trans. Ralph Mannheim (London: Lund Humphries, 1961), lecture of November 14, 1921, 99-100 and undated lecture note, 67.

${ }^{68}$ Klee, The Thinking Eye, lecture notes, 147.

${ }^{69}$ Klee, Thinking Eye, undated lecture note, 67.

${ }^{70}$ Klee, The Thinking Eye, undated lecture note, 66. 
creation, of the creator." 72 In this especially striking lecture, Klee gave his students the task to be open - like a naïve child first encountering the world - and to use a child's creative ability to connect to a kind of divine source ("of the creator") in their artistic process. In Klee's endeavours to attach formal principles to his work that carried the weight of a higher purpose, he turned to an idea of childhood that resounds on profound levels.

\section{Cosmic Beginnings in Childhood}

Klee's interest in primordial beginnings is a common theme in his writings. For example, in 1914 Klee wrote: "When is the spirit at its purest? In the beginning." ${ }^{, 73}$ Not long after this entry, Klee wrote in a poem of how the end of life brings one back to the beginning: "Whoever slept and caught his breath (...) found his last end in the beginning." 74

Klee continued to be occupied with beginnings as a professor. In a 1921 lecture, for instance, Klee emphasized how the "coming-into-being" is more important than the "being." ${ }^{, 75}$ Moreover, Klee encouraged students to remember in their artistic practice that:

[B]efore the formal beginning (...) there lies a whole prehistory: not only man's longing, his desire to express himself, his outward need, but a general state of mind (...) which drives him from inside to manifest his spirit in one place or another

${ }^{71}$ Franciscono, "Paul Klee and Children's Art," 111.

${ }^{72}$ Klee, Das bildnerische Denken, ed. Jürg Spiller (Basel: Schwabe, 1956), lecture note of 1922, 31, as quoted in Werckmeister, "The Issue of Childhood," 143.

${ }^{73}$ Klee, The Diaries, Diary III, entry 944, 1914, 312.

${ }^{74}$ Klee, The Diaries, Diary III, entry 948, 1915, 313.

75 Klee, The Thinking Eye, lecture notes, November 14, 1921, 99-100; Klee wrote: "[like] the book of Moses, concerned with the creation of the world, is called Genesis" (1921), The Thinking Eye, lecture notes, November 14, 192, 199-100; See Geelhaar, Paul Klee and the Bauhaus, 26; see also Verdi, Klee and Nature, 94. 
$(1921) .^{76}$

Klee's lecture implies the complexity of beginnings: it relates to a kind of inherent and primordial conscious state that "drives (...) [man] from the inside." This unconscious state is linked by the artist to a fluid and bodiless existence ("manifest his spirit in one place or another"). Klee's formal convictions indeed reveal a preoccupation with beginnings, the source of man, Genesis and Creation.

Klee's fascination with beginnings is key to what I propose drives his spiritual and cosmic engagement with childhood. This idea goes back to an earlier period in Klee's life. The 1913 work, The Unborn is Integrated in Its Future. There Will Be Only Fulfillment Of The Beginning, And The Beginning Itself Was Already Fulfillment (fig. 24), relates directly to these issues. In the image, four human-like figures lifelessly spin around a central source or light. The figures are the unborn or the pre-existing state of man. To Klee the unborn are the true source of humanity; they represent a bodiless state, a level of consciousness that directly precedes human existence and the state of childhood. Klee clearly depicts the spiritual and mystical origins of humanity where souls or spirits circulate in a cosmic realm before coming down to participate in the trials of man. The words Klee inscribed on the left of the image, which also make up the title, are poetic and reminiscent of a kind of creation fable. The statement, "there will be only fulfillment of the beginning," implies that through living and experience, one will strive for the perfection already known in the beginning, in their state before Creation, because "the beginning itself was already fulfillment."

Klee may have developed this idea of the unborn from a variety of different sources. Perhaps the concept of The Unborn is Integrated and Klee's interest in beginnings is based

${ }^{76}$ Klee, The Thinking Eye, lecture notes, November 14, 1921, 99-100. 
in Theosophical teachings, to which Klee was exposed but with which he did not necessarily associate. ${ }^{77}$ In Theosophical doctrine, the spirit descends from a kind of higher source into matter on Earth before re-emerging from the confining limits of human form back to this fluid state. ${ }^{78}$ It is this process that Klee depicts here. Goethe, whom Klee mentions several times in his diaries, also considered the state of the unborn. ${ }^{79}$ In Westöstlicher Divan, Goethe tells us of a longing in the unborn soul for death into what we call life. ${ }^{80}$ A line in the poem demands of the unborn: "Die and become!" 81 The state that precedes Creation, the precursor to this death of life, seems to be the state Klee depicts in The Unborn is Integrated. Another possible influence is Orphism, the modern art and aesthetic movement. When Klee translated La Lumière, a summary of the movement's

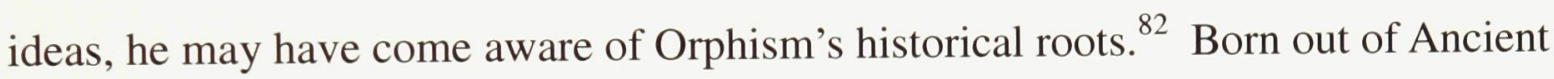
Greece, followers believed the divine soul of man is doomed to live in a body bound to "the wheel of rebirth" until metaphysical enlightenment, or a communion with the gods, is somehow obtained. ${ }^{83}$ It could be said that The Unborn is Integrated illustrates this "wheel of rebirth," the point of regaining a "cosmic consciousness" before the unborn are reincorporated into terrestrial bodies.

Importantly, Klee renders the forms in The Unborn is Integrated with the schematic

77 For mention of Theosophy in Klee's diary, see Diary IV, entry 1088, 378.

${ }_{78}$ Turkaram Tatya, Guide to Theosophy (Bombay: Theosophical Publication Fund, 1887), 225-249.

79 Klee, The Diaries, Diary II, 1904, entry 550, 149; see also Diary IV, 1917, entry 1121 , 393; and Diary II, 1901, entry 295, 69; see Diary II, 1902, entry 375, 91.

${ }^{80}$ Goethe, "Westöstlicher Divan," as quoted in Lorraine Byrne, Schubert's Goethe Settings (Aldershot, U.K.: Ashgate Publishing Limited, 2003), 219.

81 Goethe, "Westöstlicher Divan," in Byrne, Schubert's Goethe, 219.

82 Robert Delaunay, "La Lumière," in Der Sturm, trans. Paul Klee, no. 144-145 (Berlin, January, 1913); See also Jürg Spiller's introduction to The Thinking Eye, 23.

${ }^{83}$ Delaunay, "La Lumière," in Der Sturm, no. 144-145. 
quality of children's art. In this way, the work both stylistically and symbolically suggests that the closest state in earthly reality to the unborn is childhood. Moreover, we find a direct connection to the state of the unborn with childhood in a conversation between Klee and his Bauhaus colleague, Lothar Schreyer, about the meaning of their art. Klee states that it is children (along with "madmen" and "savages"), who can still see into the realm of the unborn:

[I]n our time worlds have opened up which not everybody can see into, although they too are a part of nature. Perhaps it's really true that only children, madmen and savages see into them. I mean, for example, the realm of the unborn and the dead, the realm of what can be, might be, but need not necessarily be. An in-between world. At least for me it's an in-between world (...) and I absorb it inwardly to the extent that I can project it outwardly in symbolic correspondences. Children (...) can still, or again, look into it. $^{84}$

The Unborn is Integrated is an early revelation of Klee's interest in ultimate beginnings which could be understood through paying attention to children's "instructive" pictures and using the "voices of children" in the artistic process.

\section{Conclusions}

While previously Klee's engagement with childhood has largely been viewed as a formalist endeavour, one that is in line with primitivism, reflective of socio-political events, and used as an escape from reality, I have attempted to identify the metaphysical and spiritual elements in Klee's preoccupation with childhood. Klee sought a child's vision through artistic means to communicate a sense of ultimate beginnings and a wider cosmic awareness. The "voice" of the child was a forum for Klee to access his inborn (or unborn) creative energy. In his art, Klee encourages the viewer to see past the often ${ }^{84}$ Lothar Schreyer, Erinnerungen an Sturm und Bauhaus (Albert Langen and Georg
Müller: Munich, 1956), 170-171; Also quoted in Felix Klee's Paul Klee His Life and 
simplistic or childlike forms to discover that they are filled with intricate layers of cosmic meaning, in order to "make visible" a kind of reality Klee believed only children could access. By using a childlike vocabulary for this highly meaningful end, Klee subscribes to the idea that children are all knowing and enter the world filled with innate wisdom directly from the source.

From that day in 1902 when Klee came across his childhood pictures, he saw the importance in childhood and children's art which would transform into a meaningful exploration for his absolute origins. Klee would push past the boundaries set by his contemporaries, like Kandinsky, in an attempt to reach a sense of beginnings found not only in childhood, but also through children's connection to the realm of the unborn. For Klee it was children who effortlessly achieved an affinity with the functioning of the universe; it was an affinity that the adult artist had to strive for consciously. In Klee's view, children evoked those primeval signs of the human imagination that were the source of limitless creativity and authenticity.

Work in Documents, trans. Richard and Clara Winston (New York: Braziller, 1962), 184. 
Chapter Two

\title{
Paul Klee and the Wild Child as Spiritual Revelation
}

\author{
Our childhood is the single \\ unmutilated nature(...) [children] \\ are representations of our highest \\ perfection in the ideal, hence, \\ they transpose into [the] \\ sublime. ${ }^{*}$ Schiller
}

The previous chapter addressed the representation of Paul Klee's connection to childhood in the scholarly literature. It also looked at Klee's desire to connect to a higher consciousness and to return to a true primordial beginning - the realm of the unborn through an attempt to regain a childlike sensibility. This chapter has two central goals. The first is to recognize how Klee valued children's inherent senses; and the second is to address in Klee's writings and works the deep appreciation he held for children in their presocialised and unaffected states. Klee longed for an understanding of the uncultivated and unencumbered minds of children because, in his view, they were still linked to a sense of primordial beginnings and the natural state of man. It was through coming closer to children in this sense that Klee sought his own artistic origins and limitless creative potential. However, in his explorations of what he considered unaffected childhood, Klee ultimately desired to discover "higher" realms and arrive at a sense of spirituality.

To clarify these goals, I will first examine Klee's Schoolhouse, which values a naïve child's vision. This work will introduce the idea that Klee appreciated a truly unaffected state of childhood. I will then discuss the notion of the wild child in relation to Klee's

\footnotetext{
* Schiller, "On Naive and Sentimental Poetry," part 1.
} 
fascination with an unencumbered childhood experience. This includes an interest in children's unrepressed sexuality and in an unrefined, chaotic and wild aesthetic. I will end this chapter with an argument that Klee viewed wild children as closer to beginnings and, ultimately, connected to "higher" forces or what Klee called the "in-between world."

\section{Rejecting the Schoolhouse}

The idea that Klee rejected the socialising influence of schoolhouses that serve to remove children from their inherent natures finds expression in the 1920 work, Schoolhouse (fig. 25). James Smith Pierce has interpreted Schoolhouse in relation to folk art and tells us the work has the overall appearance of a Bavarian glass painting in the use of colours black, yellow, and red; the flower is also a popular folk motif. ${ }^{1}$ Klee's formal references to folk art allow for an intriguing analysis of the work's iconography and subject matter.

The central personage is a schoolmaster figure. His white face that lacks eyes or a mouth is ghostly and skeletal. The two schoolhouses in the image are prison-like with their cross-hatched window bars. These strikingly morbid images of the schoolhouse and schoolmaster are contrasted to the grand and sensuous flowers in the landscape: the central purple daisy and the white daisy turned away from the viewer in the top left corner.

In this work, Klee includes motifs that reappear later in his fish works like the 1925 Fish Magic (fig. 26). Franciscono tells us Fish Magic is reminiscent of a Surrealist fascination with the strangeness of objects: for example, Klee's depiction of cut flowers

\footnotetext{
${ }^{1}$ Pierce, Paul Klee and Primitive Art, 13.
} 
in vases along with ticking clocks under the sea. ${ }^{2}$ One can certainly apply these ideas to Schoolhouse with its inclusion of a fish and the red splashes of colour in the landscape. Klee presents a fresh and unscathed vision of reality - a child's imaginative and fantastical landscape - with the looming and prominent flowers, the fish, and the red splashes. These details are indicative of a more naïve view of what is there: a dreaded schoolhouse and its corresponding master. The inclusion of the fish may also refer to the idea that children belong in schools as much as fish belong in dry landscapes - a notion that the English saying, "a fish out of water," implies.

This sentiment is not new to Klee. German Romantic painter Caspar David Friedrich, whom Klee admired greatly, had warned against teachers who impose their knowledge, abilities and rules that "could easily break the fragile flowers, destroy the temple of individuality without which man can achieve nothing great."3 Similarly, Klee relates through Schoolhouse how institutions of "learning" remove children from nature. The schoolhouse not only robs children of a naïve vision of reality (the fish, the splashes of colour), but of an experience of nature that can be found on the outside among the flowers in the landscape. In light of the morbid schoolmaster, Klee also suggests that removing children from the state of nature can take away life. Klee's friend and colleague, Kandinsky, shared in this view that education deprives children of something

\footnotetext{
${ }^{2}$ Franciscono, Paul Klee: His Work and Thought, 262.

3 Caspar David Friedrich, "Über Kunst und Kunstgeist," in Caspar David Friedrich in Briefen und Bekentnissen, ed. Sigrid Hinz (Munich: Rogner and Bernhard, 1968), 84, as quoted in Mitchell B. Frank, German Romantic Painting Redefined: Nazarene Tradition and the Narratives of Romanticism (Aldershot: Ashgate Press, 2001), 37-38; Klee's interest in Caspar David Friedrich is discussed by Tulliola Sparagni "Paul Klee und die Romantik" in Paul Klee und die Romantik, ed. Brigitte Reinhardt (Hatje Cantz and Ulmer Museum, 2009), 9-27; and Dorothea Richter, "Die kühle Romantik dieses Stils ohne Pathos ist unerhört” in Paul Klee und die Romantik, 27-40.
} 
meaningful. In On The Spiritual in Art, Kandinsky relates how the "accumulation of experiences" acquaints children with the world around them. ${ }^{4}$ Eventually these experiences, combined with socialisation, like that in the classroom, deprive children of their inherent "vivid, intense interest." Schoolhouse represents a desire to free children from their school-prisons and to relocate them where they are most suited, in nature.

Schoolhouse is compelling considering Klee created the work around the time he was working out the formal principles of his art process for a Bauhaus classroom (1920). In a staunch rejection of what Klee was soon to be engaged in - teaching students at an institution - Klee presents the idea that it is not learning that is important but a sensitivity to nature and a value of one's senses.

In a lecture note from 1922, Klee addresses these notions:

Genius cannot be taught. The School had best keep quiet about genius (...) The school had best lock up the secret and guard it well. For if this secret were to emerge from latency (...) It would stir up a revolution. Surprise and perplexity. Indignation and expulsion. Out with the total synthesist! Out with the totaliser! We're against! And the insults would fall like hail: Romanticism! Cosmicism! Mysticism! In the end we should have to call in a philosopher, a magician!... We should have to hold classes (...) outside the school. Out under trees, with the animals, by the side of brooks. Or on the mountains in the sea (1922). ${ }^{6}$

True and effective learning, according to Klee, will result from reacquainting oneself with a buried inner source, from taking mysticism seriously, and from renewing our lost connection to nature. Such a lost connection can be found in Klee's interest in the "wild child."

${ }^{4}$ Wassily Kandinsky, "On the Spiritual in Art" (1912), in Kandinsky: Complete Writings on Art, ed. Kenneth C. Lindsay and Peter Vergo, vol. 1 (Boston, Mass.: G. K. Hall \& Co., 1982), see "About Painting," part II, 26.

${ }^{5}$ Kandinsky, "On the Spiritual in Art," part II, 26-27.

${ }^{6}$ Klee, The Thinking Eye, undated lecture note from "exact experiments in the realm of art," 70 . 


\section{The Wild Child as a Source for Uncultivated Beginnings}

\section{The Wild Children of Europe}

The "wild child" was an eighteenth- and nineteenth-century European phenomenon. Peter the Wild Boy, Kaspar Hauser, and Victor of Aveyron, for example, lived in isolation or with animals, and acted according to their impulses, drives and needs. ${ }^{7}$ These supposed children of nature were often lamented by scientists, who saw them as a pathway to the animals and our own bestial and primal existence. ${ }^{8}$ It was reported that these children, through experiences with their surroundings, had highly developed senses. ${ }^{9}$ As such, they were viewed as having an unmediated connection with the world around them. ${ }^{10}$ German Expressionist writers, such as Gottfried Benn, Georg Heym and Georg Trakl, idealized this sensual and unmediated experience of the unencumbered child as pure. Art historian Frederick S. Levine has shown that these figures and the wider German Expressionist movement rejected what they perceived to be a corrupt and decadent bourgeois society, and placed value, rather, on the "the primitive, prelogical, and instinctual life as a correspondingly more positive and attainable end." ${ }^{\prime 1}$ This included an interest in feral children, especially Kaspar Hauser (see fig. 27). ${ }^{12}$

Despite these high praises, untamed children were also believed to be uncontrollable

${ }^{7}$ Daniel Defoe, Mere Nature Delineated. Or, a Body Without a Soul (London: T. Warner, 1726), as quoted in Newton, Savage Girls, 43.

${ }^{8}$ Newton, Savage Girls, 39, 100, 104.

${ }^{9}$ Newton, Savage Girls, 116.

${ }^{10}$ The physician who studied Victor of Aveyron, Jean M. G. Itard, for example, envied Victor's immediate sensory experience in nature, see Newton, Savage Girls, 117.

${ }^{11}$ Frederick S. Levine, The Apocalyptic Vision: The Art of Franz Marc as German Expressionism (New York: Harper and Row Publishers, 1979), 105.

${ }_{12}$ Georg Trakl, "Kaspar Hauser Lied," in Hamburger and Middleton, Modern German Poetry, (London: Jonathan Cape, 1968), 126-127, cited in Levine, The Apocalyptic Vision, 112-113. 
and governed only by their own impulses. Therefore, they were thought to have proclivities to wild behaviour and unrepressed sexualities. According to Hayden White and Edward Dudley, wild children were thus seen as relentless sinners against God. ${ }^{13}$ Klee did not illustrate this aspect of the Wild Child, but he did romanticize the wild experience because of its emphasis on a type of unmediated sensual experience.

\section{Wild Sensibilities in a Return to Childhood}

In a diary entry from 1906, Klee describes how he returned to "the beginning" in a dream. In the entry, the artist attributes great value to an unaffected, primal experience dependent upon the senses:

Dream. I flew home, where the beginning lies. It started with brooding and chewing of fingers. Then I smelled or tasted something. The scent freed me. I was completely freed at once and melted away like a piece of sugar in water. My heart (...) [was] blown up to inordinate size (...) [there was] no trace of oppression (...) I was there where the beginning lies. ${ }^{14}$

Werckmeister and Fineberg have described this dream as a key indicator of the artist's desire to return to his childhood sensibility: "the beginning."15 To add to this interpretation, Klee indicates that this "beginning" was a not only a space of childhood, but represented a return to a primordial sensibility. At this point of origin, Klee was governed only by his senses ("I smelled or tasted something") and his actions were primal ("it started with brooding and chewing of fingers"). In this process of senseforming, Klee recounts how he was "completely freed at once and melted away like a

\footnotetext{
${ }^{13}$ Hayden White, "Forms of Wildness," 22; and Edward Dudley, "The Wild Man Goes Baroque," in The Wild Man Within, 125.

${ }^{14}$ Klee, The Diaries, Diary III, entry 748, February 1906, 194.

${ }^{15}$ Werckmeister, "The Issue of Childhood," 155; see also Fineberg, The Innocent Eye, 84.
} 
piece of sugar in water" and his heart was full. ${ }^{16}$ Moreover, in the "beginning," there was "no trace of oppression" or societal pressures and modern corruptions. ${ }^{17}$ This dream is both an expression of a return to childhood and of the experience of life through an unaffected child's faculties.

The natural senses and instincts were encouraged in Klee's classroom: "The preliminary stirrings within us (...) these are the main components of the creative totality (...) the inner impulse (...) As in nature, so with us." 18 According to Klee, these inner drives or stirrings were essential "to recognize our own creativity."19 Moreover, Klee asked of his pupils to experience nature through full use of the senses, such as with touch and sound, and not only sight. ${ }^{20}$

Another common theme in Klee's notes is a return to a pre-existing sense of wholeness. For example, he states in 1922: "we must work our way back to unity.",21 This recurring notion of a return to a previous sense of fulfillment runs concurrent to another theme: the idea of searching for this unity in "primitive" beginnings. In many lectures, for example, Klee refers to the concept of a "primitive" past and regaining a primordial consciousness. ${ }^{22}$ Often, these statements are in proximity to praises of the uncorrupted child's vision or an encouragement of assuming the role of an uninfluenced

${ }^{16}$ Klee, The Diaries, Diary III, entry 748, February 1906, 194.

${ }^{17}$ Klee, The Diaries, Diary III, entry 748, February 1906, 194.

${ }^{18}$ Klee, The Thinking Eye, undated lecture note, 259.

${ }^{19}$ Klee, The Thinking Eye, undated lecture note, 259.

${ }^{20}$ Klee, The Thinking Eye, lecture of 1922, 463.

${ }^{21}$ Klee, The Thinking Eye, lecture, 153.

${ }^{22}$ Klee, The Thinking Eye, lectures, 103, 451, 168. 
child in the creative process. ${ }^{23}$ All in all, it seems that Klee desired to free himself through his art from the bounds of a cultivated adult's sensibility and to regain a wholeness experienced by unencumbered children.

\section{Uncultivated Sexuality in a Wild Childhood}

From as early as 1905, Freud had identified children's active sexual drive, however abhorrent this was to prevailing attitudes towards children. ${ }^{24}$ What is interesting is that while children in cultivated Western society were viewed largely as nonsexual, the sexual tendencies of wild children were often described as unrepressed. ${ }^{25} \mathrm{Klee}$, as can be gleaned from his writings and work, valued the child's unmediated sexual nature.

In 1911, in an act to associate (or re-associate) himself with the state of untamed childhood, Klee added several memories to his diaries which indicate his active sexual sensibility from when he was two- or three-years old. From one such memory, Klee wrote: "In a dream I saw the maid's sexual organs; they consisted of four male (infantile) parts and looked something like a cow's udder (two to three years)." ${ }^{26}$ There are other accounts of children's sexualities in his writings. In a memory from preparatory school, for example, Klee relates: "During class I saw a fellow student sitting in front of me

${ }^{23}$ Klee, Das bildnerische Denken, ed. Jürg Spiller (Basel: Schwabe, 1956), lecture note of 1922, 31, cited in Werckmeister, "The Issue of Childhood in the Art of Paul Klee," 143.

${ }^{24}$ Sigmund Freud, Three Essays on the Theory of Sexuality (1905), trans. James Strachey (New York: Basic Books, 1962).

${ }^{25}$ See Coveney, The Image of Childhood, 300-302; Heywood, Growing Up in France, 62, 271; Beth Bailey, "Sexuality," in Encyclopedia of Children and Childhood, ed. Paula F. Fass, vol. 3 (New York: Macmillan Reference USA, 2004), 743-749.

${ }^{26}$ Klee, The Diaries, Diary I, "Memory" 8, 4. 
masturbating in the shadow of his desk (eleven years)."27 Often these memories have a confession-like character to them and Klee was, in fact, reprimanded for his sexual imagination. Klee tells us that he was caught with pornographic drawings he had made and consequently his mother scolded him. ${ }^{28}$ In this way, Klee's natural tendencies had been repressed.

In Sexual Discoveries of a Boy (1918) (fig. 28), Klee links a wild child experience to an open sexuality. Expressed in a disjointed cubist vocabulary, we find a boy in a forest under a mystical and looming moon. An uncanny creature is in the wilderness with the child. As the title implies, Sexual Discoveries is a fragmented story of a boy realizing his sexuality through his encounter with a wild beast. Verdi relates this work to Klee's interest in botany and the sexual behaviour of plants. Sexual Discoveries, according to Verdi, is an early example of Klee's fascination with the sexual operations of nature. ${ }^{29}$ But surely this work can be understood as a child's discovery of his sexual nature.

Reminiscent of Klee's strange childhood dream of the maid's cow-udder organs, Klee presents an unsettling female beast (judging from the eyelashes) with exposed breasts that look something like testicles. Moreover, the beast's singular eye signifies an archaic animal. As told to us in Homer's Odyssey, the Cyclops is a savage and cannibalistic creature whom Odysseus blinds. ${ }^{30}$ This "castration" of the Cyclops for his gluttony, from a Freudian perspective, may be readily related to this lustful scene where the organs of the beast are exposed. The Cyclops' actions may invite castration because it appears she

${ }^{27}$ Klee, The Diaries, "Memory" 33, 10.

${ }^{28}$ Klee, The Diaries, "Memory" 34, 10.

${ }^{29}$ Richard Verdi, Klee and Nature (London: A. Zwemmer Ltd., 1984), 1-3.

${ }^{30}$ Homer, The Odyssey, ed. Robert Squillace, trans. George Herbert Palmer (New York: Barnes and Noble, 2003), 103-116. 
has found a mate in the small boy - a taboo union of child and beast. ${ }^{31}$ The child's behaviour may also provoke a sense of castration. Freud spoke of the castration anxiety children experience during the course of their psycho-sexual awakening. Boys are especially made to fear castration, Freud tells us, by the father for their attraction to the mother - the "Oedipal" stage. ${ }^{32}$ According to Freud, castration is also a concern for children because parents, at least in the late $19^{\text {th }}$ century, would threaten them with castration if they "misbehaved." 33 Due to the shame and fear induced by parents and as a result of wider societal pressures, such as the conforming influences in school, children pass through a "latency period" which interrupts their sexual development. This “repression” transitions into a more destructive stage which, Freud tells us, will ultimately manifest in adulthood as an unconscious psychosis around sexuality. ${ }^{34}$ In Sexual Discoveries, societal repressions seem peripheral since the boy is in the wilderness and confidently waves to the viewer, implying that he is comfortable or in touch with his sexual "nature." Indeed, the image speaks to our unrepressed behavioural drives in childhood that are natural and primal. Unlike Klee's childhood memories that describe how he was scolded and made to feel shame for his sexual thoughts, the child in Sexual Discoveries appears free to explore these possibilities - and seems to thrive in them.

\footnotetext{
${ }^{31}$ Mark Buchan, "Food for Thought: Achilles and the Cyclops," in Eating their Words: Cannibalism and the Boundaries of Cultural Identity, ed. Kristen Guest (Albany: State University of New York, 2001), 16-20.

32 This "Oedipal" phase is slightly different for girls, see Sigmund Freud, "The Dissolution of the Oedipal Complex" (1924) in On Sexuality, vol. 7 of Penguin Freud Library, ed. Angela Richards, trans. James Strachey (Harmondsworth: Penguin, 1976), 318.

${ }^{33}$ Freud, "The Dissolution of the Oedipal Complex," 316-317.

${ }^{34}$ Freud, "The Dissolution," 319-320.
} 


\section{The Wild Child Aesthetic}

I have suggested that Klee was interested in unaffected childhood and untamed impulses. He also believed that, to be a "child of Creation," he would have to understand an unencumbered artistic process and skill set. ${ }^{35}$ In 1905, for example, Klee wrote in his diary about his developing practice:

I am ripe for the step forward. I begin logically with chaos, it is the most natural start. In doing so, I feel at rest because I may, at first, be chaos myself (...) It's convenient to have the right to be chaos to start with. ${ }^{36}$

This "chaos" that Klee appreciates in his art making is interesting in that it indicates Klee desired a wild and unregulated style to aid him in his "step forward" to artistic freedom.

The chaotic in unaffected children's pictures is also of value to Klee. Let us revisit the 1911 quote addressed in the first chapter which further relates to Klee's appreciation of the unaffected pictures of childhood:

For there are primordial beginnings in art, which one is more likely to find (...) at home in the nursery (...) Do not laugh, reader! Children also have artistic ability, and there is wisdom in their having it! The more helpless they are, the more instructive is the art they offer us; for there is (...) a corruption (...) when children begin to absorb developed works of art or even imitate them. ${ }^{37}$

This text indicates Klee's interest in a kind of primordial and cosmic beginning that children can access; it also suggests that the "instructive" nature of children's pictures is fleeting. Their pictures can be direct expressions of a spontaneous and creative energy, but they later become corrupted "when they begin to absorb developed works of art." In Klee's way of thinking, the art of unaffected children is a window to man's "higher"

\footnotetext{
${ }^{35}$ Klee, Das bildnerische Denken, lecture note of 1922, 31, as quoted in O. K. Werckmeister, "The Issue of Childhood in the Art of Paul Klee," 143.

${ }^{36}$ Klee, The Diaries, Diary III, entry 633, 1905, 175-176.

${ }^{37}$ Klee, Schriften, Rezensionen und Aufsätze, ed. Christian Geelhaar (DuMont: Cologne, 1976), 97.
} 
intention and it can tell us of the origins of humanity. He articulates such ideas in a 1921

lecture to his students:

At the dawn of civilization, when writing and drawing were the same thing, it [line] was the basic element. And as a rule (...) children begin with it; one day they discover the phenomenon of the mobile point (...) at first the pencil moves with extreme freedom, wherever it pleases... [soon] the free motion (...) is subordinated to anticipation of a final effect; cautiously the child begins to work with a very few lines (...) [Artists need] to discover a way of enriching the pitiful result [of their work] without destroying or blurring the simple (...) It becomes necessary to establish a relation between these things of first importance and those which are subsidiary. ${ }^{38}$

Klee connects children's drawings with a primordial and unregulated artistic skill set that is chaotic. He encourages his students to return to this type of artistic vision that is both wild and simplistic.

Franciscono and Werckmeister have argued that Klee's pedagogical work stresses a systematic progression from the simple to the complex rather than a free and unconscious method. This, they state, was likely influenced by Gropius' directive of October 13, 1920, which made theory courses compulsory in order to correct what the Bauhaus director perceived to be the "chaotic" in students' work. ${ }^{39}$ Klee may have attempted to follow Gropius' advice and present the artistic process as logical and progressive.

Nonetheless, the above lecture reveals that Klee was able to bring into his classroom an aesthetic that he valued: the chaotic first lines of primordial children. Klee tells his students that children work "very few lines," and that artists should attempt to attain the original simplicity apparent in this type of picture-making.

We can distinguish between Klee's works that present a childlike aesthetic and those

${ }^{38}$ Klee, The Thinking Eye, lecture from November of 1921, 103.

${ }^{39}$ Werckmeister, The Making of Paul Klee's Career, 248; Franciscono, Walter Gropius and the Creation of the Bauhaus in Weimar (Urbana: University of Illinois Press 1971), 175. 
that reflect a type of "wild child" style. In the former, Klee's lines are simplistic and twodimensional, yet they also are controlled and aim to present identifiable objects and symbols. The drawing A Child's Villa (1923) (fig. 29), for example, employs simplistic yet consciously controlled lines to form a figure of a child, a geometric house, and pet dog. Many of Klee's paintings that can be characterized as childlike are also simplistic and controlled. For example, The Pony (1918) (fig. 30) presents a simplistically rendered horse, a flat landscape, and square, childlike houses. The star in the picture also appears childlike in that it is simplistically comprised of two triangles. ${ }^{40}$ In what we can call the "wild child" style, Klee's lines are less defined and often chaotic. For example, in Scene in the Restaurant (1911) (fig. 31) the lines run in several, confusing directions and the schematically rendered people seated at tables are also presented in this "wild" and almost scribbled manner. Aside from chaotic drawings, often this "wild child" aesthetic is conveyed through paints which appear to have been applied crudely by use of fingers, as seen in Kindergarten (1939) (fig. 32). Moreover, these types of works employ darker colours, mostly muddy browns, murky greens, grays, and blacks, such as we find in Kindergarten, as opposed to the brighter palette of The Pony. ${ }^{41}$

Both styles are present in Klee's oeuvre. However, the wild child aesthetic is particularly interesting because it relates more readily to Klee's interest in unencumbered senses and often carries a kind of higher resonance. In chapter one, I concluded with Klee's conversation with Lothar Schreyer where the artist suggests that children are

\footnotetext{
${ }^{40}$ The two-triangle star also carries spiritual and religious symbolic value. I address these ideas below.

${ }^{41}$ The Paul Klee Catalogue Raisonné, ed. the Paul-Klee-Stiftung, vol. 8 (New York: Thames \& Hudson, 1998-2004), 1939, cat. no. 8905. The entry states that the coloured paste material used in Kindergarten is black (Schwarz Kleisterfarbe) and is applied to a dark tinted paper.
} 
connected to the realm of the unborn and the dead, what he called the "in-between

world." In the same conversation, Klee states that it is children "who can still, or again, look into it [the in-between world]. And what they see and picture is for me the most precious kind of confirmation. ${ }^{42}$ Klee appreciates the uncorrupted character of uninfluenced or wild children's pictures because they can tell us of these primordial and spiritual realities. In this way, they are "instructive" to us.

\section{Higher Meaning in a Wild Childhood}

Wild children were viewed by German Expressionists as linked to the spiritual.

Austrian poet, Georg Trakl, for example, communicates this idea in the poem "Kaspar Hauser Lied," which first appeared in 1913:

He truly adored the sun, as crimson it sank from the hill-top

The paths of the forest, the blackbird singing

And the joy of green.

Serious was his habitation in the tree-shade

And pure his face

God spoke a gentle flame into his heart:

O man!

His silent footsteps found the city at evening

House and pallid garden of pallid men

And his murderer sought him...

Beautifully the spring and summer of the autumn

Of the righteous man, his soft footfall

Beside the dark room of the dreamers.

By night he stayed alone with his star;

Saw snow falling through bare branches

And in the dusking hall his murderer's shadow

${ }^{42}$ Schreyer, Erinnerungen an Sturm und Bauhaus, 170-171; also quoted in Felix Klee, Paul Klee: His Life and Work in Documents, 184. 
Silver it fell, the head of the not-yet-born. ${ }^{43}$

Frederick Levine has argued that Trakl's poem presents a life of innocence - a life that was lived to its full potential in the wild - that is destroyed by the "murderous" city. ${ }^{44}$ Trakl also links the experience of the wild child to a divine existence (his "pure face," or the idea that God burned gently in his heart). Before Kaspar came upon the city, he lived in God's image and "alone with his star." In his pure and unencumbered state, Kaspar remained unborn ("not-yet-born"). This idea of wild children being unborn is particularly of interest for Klee believed that children resided closer to the unborn and the "inbetween world." 45

Similarly for Klee, the child's unencumbered experience has great importance, as suggested further in The Child and the Star (1912) (fig. 16) and Childhood of the Chosen One (1930) (fig. 33). The deliberate crudity of the works is striking and they each exhibit aspects of the wild child aesthetic I have identified in Klee's work. The wildly drawn lines for the figure's body in The Child and the Star, for example, appear childlike, but they also have an unregulated and chaotic character. Childhood of the Chosen One also reflects this wild aesthetic in the dark grey colours and the crude style that appears almost finger-painted. What is more, Klee seems to suggest that the children in the images are in fact wild since they are depicted alone. This idea is perhaps more apparent in Childhood of the Chosen One where a lone child is depicted on a landscape near a cave or the hermit's dwelling.

${ }^{43}$ Georg Trakl, "Kaspar Hauser Lied," in Modern German Poetry, ed. Hamburger and Middleton (London: Jonathan Cape, 1968), 126-127.

${ }^{44}$ Levine, The Apocalyptic Vision, 112-113.

${ }_{45}$ Schreyer, Erinnerungen an Sturm und Bauhaus, 170-171; see also Felix Klee, Paul Klee: His Life and Work in Documents, 184. 
The idea of hermit-like children directly relates to the feral children found in Europe, who lacked human contact before their "discovery." They were also not able to communicate effectively with others. ${ }^{46}$ In an earlier work, Child as Hermit (1920) (fig. 34), Klee took up the idea. In the image a child, whose figure looks like it could be taken from a child's picture, peers out of a doorway, debating whether or not to leave the hermit's abode. ${ }^{47}$ The youths in Child and the Star and Childhood are also hermit-like, yet, in these cases, Klee emphasizes the children's wildness and suggests that in this unencumbered state, children can access higher possibilities through the inclusion of the overarching hexagram stars.

I discussed above that the two-triangle star in The Pony is a simplistic and childlike way in which to render a star. This star or hexagram is also a widely recognized symbol of Judaism. ${ }^{48}$ In the nineteenth century, the Star of David, as it is referred to, was used to represent Zionist movements and in 1947, the symbol came to represent the nation of Israel. ${ }^{49}$ In this tradition, the star is often viewed as a divine symbol of the protection of God. ${ }^{50}$ The hexagram symbol, however, also refers to a variety of other traditions. The ancient Pythagoreans and Eastern orthodoxy such as Buddhism, Hinduism, and Jainism viewed the star as a symbol of the cosmic spirit. ${ }^{51}$ The hexagram star was also

\footnotetext{
${ }^{46}$ Newton, Savage Girls, 44, 46-47.

${ }^{47}$ Helfenstein, "The Issue of Childhood in Klee's Late Work," 142-144. Helfenstein concludes that Child as Hermit may be a reflection of Klee's own feelings of isolation. ${ }^{48}$ R. J. Zwi Werblowsky and Geoffrey Wigoder ed. The Encyclopedia of the Jewish Religion (New York: Holt, Rinehart and Winston, Inc., 1966), see "Magen David," 246. ${ }^{49}$ Bernard Martin, A History of Judaism, vol. 2 (New York: Basic Books, Inc., 1974), 379; see also R. Brasch, The Star of David (London and Sydney: Angus and Robertson, 1965), 247.

${ }^{50}$ James Hall, Dictionary of Subjects and Symbols in Art, second edition (Boulder, Co.: Westview Press, 2008), see "hexagram."

${ }^{51}$ Hall, Dictionary of Subjects, "hexagram."
} 
incorporated into traditions of Christianity, Occultism, and Theosophy. ${ }^{52}$ In the Christian faith, the hexagram is often called the Star of Creation and is used in representations of the Adoration of the Magi. In this view, the symbol represents the birth of the Christ child. ${ }^{53}$ In the Theosophical tradition, the hexagram is referred to as the Seal of Solomon and relates to the dual nature of the universe as spirit and matter. ${ }^{54}$

It is likely that Klee adopted this symbol because of its mystical significance. In his diary, Klee observes: “A star (...) two beings who are identical (...) Sacred stones, yesterday; today, meaning!" 55 The two identical beings of the star could be read in terms of the hexagram which is comprised of twin and equilateral triangles. Since Klee was aware of Theosophy, his view of the dual nature of stars could refer to the Theosophical interpretation of the hexagram as a symbol of involution and evolution, spirit and matter. ${ }^{56}$ Moreover, Klee states that the two-triangle star was a "sacred stone, yesterday" - perhaps recognizing the star's significance in age-old religious and spiritual movements - and he implies that it held significance or certain "meaning" to him ("today, meaning").

Klee often incorporates this symbol in his work to refer to the otherworldly, for example, in Oracle (1919) (fig. 35). Werckmeister interpreted "the telltale signs of the

\footnotetext{
${ }^{52}$ Hall, Dictionary of Subjects, "hexagram."

${ }^{53}$ Hall, Dictionary of Subjects, "hexagram."

${ }^{54}$ Tukaram Tatya, A Guide to Theosophy (Bombay: Theosophical Publication Fund, 1887), 84-86.

${ }^{55}$ Klee, The Diaries, Diary III, entry 947, 1914, 312.

${ }^{56}$ Klee mentions Theosophy in his diaries, see The Diaries, Diary IV, entry 1088, 378;

Werckmeister discusses Klee's interests in Theosophy in The Making of Paul Klee's Career, 45, 111, 213, 215-216; Klee's close friend and colleague, Kandinsky, was a follower of Theosophy. See Virginia Hanson, H.P. Blavatsky and the Secret Doctrine (Wheaton, IL: The Theosophical Publishing House, 1988), 217-221; See also Tatya, $A$ Guide to Theosophy, 84-86.
} 
hexagram, half-moon, and a Christian cross," in Oracle as "mystical" symbols. ${ }^{57}$ The public admired this mystical work, Werckmeister tells us, since it sold for the top price at the 1919 exhibition at the New Munich Secession. Judging from Klee's observation of the identical "two beings" of the star, and its appearance in highly mystical works like Oracle, Klee's use of the six-pointed star suggests he viewed it as a mystical and spiritual symbol.

In chapter one I pointed out that Franciscono relates The Child and the Star to Goethe's Faust in that it is a symbolic representation of the genius known in childhood in his/her reaching for a star. ${ }^{58}$ The image also exhibits some parallels to the idea that unencumbered children were closer to spirituality. In the image the child is reaching for, or playing with, this mystical star. ${ }^{59}$ Given that the child's palm is open to the star, it also appears that the child desires to hold it in his/her hand. In line with German Expressionist sentiment, this work suggests that, in Klee's view, unaffected children have a more immediate sense of the spiritual and are closer to achieving this connection.

Klee's Childhood of the Chosen One can also be understood within the context of relating spirituality to a wild childhood. In the image, a child stands alone on a landscape near a cave or den and up above shines another hexagram star. Given the date of the piece (1930), the inclusion of the star could, perhaps, be interpreted as a symbol of the Jewish tradition and to contemporary events in Germany. The National Socialist party was gaining power by 1930 and this led to heightened discrimination towards Jewish

57 Werckmeister, The Making of Paul Klee's Career, 188.

${ }^{58}$ Franciscono, "Paul Klee and Children's Art," 103-104.

59 The child's hand reaching towards the star also evokes the image of the hands in Michelangelo's Creation of Adam. 
populations. ${ }^{60}$ In this perspective, the work may reference the wandering Jew in Christian/Jewish/or anti-Semitic iconography, only in this case the spiritual outsider is a child. ${ }^{61}$ At the same time, it seems unlikely that Klee is referring specifically to Judaism, given that Klee was using this symbol in his work as early as 1912, and in 1919 in relation to mysticism (Oracle). Moreover, the Star of David was not yet used as a symbol of Jewish identification by the Nazis in $1930 .{ }^{62}$ Instead Klee seems be using the star in a more general spiritual sense. The star affords us a vision of the unity, harmony, and spiritual connection known in untamed childhood.

This interpretation of Childhood can be related to a Swiss/German mystical tradition evident in the work of Ferdinand Hodler, whom Klee deeply respected. ${ }^{63}$ In The Chosen One (1893-94) (fig. 36), a naked "child of nature" is shown looking upward, supposedly engaging with some sort of higher force. ${ }^{64}$ While Hodler's child is surrounded by angelic women who seem to help this child connect to higher forces, Klee's child is alone on the landscape and therefore has this connection to spirituality by merit of his unscathed and hermitic wildness. ${ }^{65}$ As such, Klee's image takes the idea of a "pure" and spiritual child

${ }^{60}$ Helfenstein, "The Issue of Childhood in Klee's Late Work," under section "Childhood and War," 133-138. Helfenstein discusses the National Socialists and their effects on Klee's art.

${ }^{61}$ For information on the wandering Jew in the wild, see Karl Blind, "Wodan, the Wild Hunstman, and the Wandering Jew," in The Wandering Jew, ed. Galit Hasan-Rokem and Alan Dundes (Bloomington: Indiana University Press, 1986), 169-189.

${ }^{62}$ Bernard Martin, A History of Judaism (New York: Basic Books, Inc., 1974), 379; see also Brasch, The Star of David, 247.

${ }^{63}$ In 1911, Klee wrote of Holder, "Before anything else, Hodler is an interpreter of people, who can create the soul by painting the body, better than anybody," see Brüschweiler J, Magnaguagno G., Ferdinand Hodler (Zurich, Switzerland, Kunsthaus Zürich, 1983).

${ }^{64}$ Sharon L. Hirsh, Hodler's Symbolist Themes (Ann Arbor, Michigan: UMI Research Press, 1983), 78.

${ }^{65}$ Hirsh, Hodler's Symbolist Themes, 76-78. 
further to suggest that the child in the image is completely separate from civilization's corrupting forces and, like Trakl's Kaspar Hauser, remains "alone with his [or her] star."66

This juxtaposition also evokes a sense of Klee's pessimism towards modernity.

Hodler's child has the help of floating angelic women and therefore we are hopeful that the child's goal in connecting to the divine is attainable. In Childhood, rather, there is a sense that adult, civilized man has left behind his/her primal child instincts and inherent connection to "higher" forces. Klee presents a child left alone in nature who is responsible for accessing these forces on his/her own. Childhood is an image of the intended nature of man and, at the same time, suggests that modern humanity is increasingly moving away from this primal, wild, and childlike state.

\section{Homeland in a Wild Childhood}

In his 1930 article "Kinder über Paul Klee," Hans-Friedrich Geist marvels at Klee’s ability to dispel "the nag of reason" and reach into the unchecked source of creativity within himself. ${ }^{67}$ According to Geist, Klee was able to return "home" to the world of the child. ${ }^{68}$ Searching for a sense of "home" in childhood is the theme of Klee's 1929 work, Homeland (fig. 37). Presented with the deliberate crudity that captures the "wild child" aesthetic discussed above, we find a schematically drawn house and stick-figure as if from a scribbled child's wilderness land.

One can speak of Klee's desire to return to a primal and childlike existence due to its "wild" vocabulary and the work's title, Homeland. The work can be interpreted as a kind

\footnotetext{
${ }^{66}$ Trakl, "Kaspar Hauser Lied,” 126-127, as quoted in Levine, The Apocalyptic Vision, 112-113.

${ }^{67}$ Geist, "Kinder über Paul Klee," 21.

${ }^{68}$ Geist, "Kinder über Paul Klee," 21.
} 
of ultimate habitat for a rejuvenated and regenerated race of men. In this space closer to the experience of an unaffected childhood, man could return to a sense of fulfillment, a concept reminiscent of Klee's drawing of the unborn discussed above: There will be Fulfillment in the Beginning, and the Beginning Itself was Already Fulfillment. Not only could a "higher" connection be achieved "where the beginning lies," it was a true homeland.

\section{Conclusions}

Klee's work that explores the complexities of childhood received strong criticism. In 1920, for example, a hostile critic of his exhibition at the Goltz Gallery insisted that Klee's watercolours - including Sexual Discoveries of a Boy - were nonsensical and compared his work with "certain Fröbel games of children (assembling motley paper chips in all possible forms)."69 Klee's childlike work that exhibited a wild and unrefined style was also attacked. For example, in 1933, art critic Robert Scholz rejected Klee's style as "mad, infantile smearings.",70 Klee's exploration of the "wild" aspects of childhood, however, was far from a simplistic and naïve pursuit. Klee returned to this type of style not only to reject convention, but to convey something about artistic creativity and spirituality. Soon after the Goltz Gallery exhibition, Klee became part of the Bauhaus faculty where his interests in childhood and the chaotic, Werckmeister tells

${ }^{69}$ Werckmeister, The Making of Paul Klee's Career, 248; see also R. B., in Münchner Zeitung, May 21, 1920, reprinted in Der Ararat, no. 8 (July 1920), 80; see The Paul Klee Catalogue Raisonne, ed. the Paul-Klee-Stiftung, vol. 2 (New York: Thames \& Hudson, 1998-2004), 1918, cat. no. 1958. Sexual Discoveries of A Boy's exhibition history record tells us that it was included in the Goltz exhibition.

70 Scholz, "Kunstgötzen stürzen," 5, as quoted in Werckmeister, "The Issue of Childhood in the Art of Paul Klee," 149. 
us, were stifled to meet new professional demands. ${ }^{71}$

Despite these new pressures, we still find in Klee's writings and work references to the idea that the desired state of man could be found in childhood. Certainly the forces of technology and modernization that brought education and assimilation had removed humanity from the state of nature. As Hayden White puts it, the difficulties of saturated modern life "unleashed a desire [in modern man] to free the lost wild child within."72 Indeed, this "lost" and repressed aspect of the human psyche was attractive to Klee.

There is irony in this fascination with wild youth since it was an idealized space which Klee could return to neither physically (as an educated adult) nor spatially (in a growing modern society). This idea finds expression in Klee's 1917 diary entry where he comments on one of the loneliest tales of wild isolation, Robinson Crusoe: "This fiction and my reality touch at many points." ${ }^{, 73}$ When he wrote this entry, Klee was in the German military due to conscription. Unlike the "wild child" who lives alone in the wilderness, Klee was an adult in modern German society, in which he found himself isolated and living a life without meaning. Klee's dream of returning "home... where the beginning lies," where his heart was "full” and his senses would guide him would only remain a dream. ${ }^{74}$ The reality would confine Klee to the modern state of humanity that was subject to industrial warfare, social restrictions, professional demands, and public criticism.

${ }^{71}$ Werckmeister, The Making of Paul Klee's Career, 246-247.

72 See Hayden White, "The Forms of Wildness: Archaeology of an Idea," in The Wild Man Within, 35; see also Newton, Savage Girls, for a discussion of these different views about releasing the wild child or Noble Savage within, 7.

${ }^{73}$ Klee, The Diaries, Diary IV, entry 1129, 1917, 404.

${ }^{74}$ Klee, The Diaries, Diary III, entry 748, 1906, 194-196. 
Chapter Three

The Higher Value of Child's Play and Fantasy in the Work of Paul Klee

Let us take a little trip into the land of deeper insight ${ }^{*}$

Paul Klee

In the previous chapter, I investigated Klee's exploration of children's uncultivated sensibilities as a source for cosmic and spiritual beginnings. In this chapter, I continue to examine Klee's view that children are spiritually connected and linked to the "inbetween" world. Specifically I will explore this idea through Klee's interest in children's mental states, play and fantasy.

Klee's investigations into the minds and mental states of children is intriguing because he paid great attention to their development, as exemplified in his study of his son, Felix. Some of Klee's writings and artistic works also express a deep desire to understand the mysteries of children's thought processes, which he links to a "higher" and cosmic consciousness. Following this examination, I will identify the connections between children's play and Klee's work. In particular I will address how this idea of the child's cosmic mental state is explored further in Klee's interest in children's play, especially in Klee's presentation of play as an energy-releasing process that is connected to the metaphysical. Klee's puppets will be discussed in this context and I draw links between children's cosmic connection through play and his puppet self-portrait.

"Klee, "Creative Credo," in The Inward Vision, 5. 
Moreover, Klee's persistent exploration of children's fantasy is also characterized by a kind of cosmic connection and spirituality. In particular, I will address how Klee's use of children's fantasy is represented as a means to transcend physical reality and achieve artistic enlightenment.

\section{Movement Around A Child}

Franciscono has related that Klee saw himself as a psychologist, a self-appraisal the artist confided to his future wife, Lily Stumpf, in a letter of $1904 .^{1}$ Probing into his own and others' inner and unconscious thought was an interest that was still intact in 1920, as revealed through Klee's imaginary device, the Psycho-Recording Apparatus (fig. 38). ${ }^{2}$ Perhaps the complex machine portrayed in this work would aid him in his psychological excavations. In fact, this interest in recording mental states is directly related to Klee's desire to acquire a childlike sensibility.

Scholars like Fineberg and Osterwold have noted Klee's diligent recording of his son's baby development in the "Felix Calendar." They do not, however, analyze the contents of individual entries, which are telling of Klee's deep interest in understanding his son's early thought processes. Beyond simply recording Felix's food intake and temperatures, Klee recorded Felix's jumbled and nonsensical baby sentences. For example, in 1909, Klee wrote:

Felix at age one and a half reached the following stage. Everything that oscillated or made a sound like a moving pendulum is called ti-ta... a horse's tail, in the leather

${ }^{1}$ Klee to Lily Stumpf, Briefe an die Familie, March 31, 1904, 411; Franciscono, Paul Klee: His Work and Thought, 40.

${ }^{2}$ Tamara Trodd similarly finds relationships between the work of Klee and Freud in Klee's oil transfer process. See Trodd, "Drawing in the Archive," 75-95. 
hand-strap on the street car (...) dangling keys (...) When a note is sounded he makes one of the same pitch. ${ }^{3}$

This entry reveals Klee's attempts to understand Felix's early language associations.

Klee continued in this fashion to record Felix's developing "child-language." Another entry, for example, reads: “[Felix] says dohdl-dohdl-gogg! Togge-doh! Doh-tay-doh!

Stogodoh! Doh-doh!" and "ent [eins, or one], vay [zwei, or two], fia [vier, or three]" or "bam [baum, or tree] and dak [dank, or thanks]." Moreover, in an entry from 1909, Klee relates what things his son enjoyed most in the world: rushing water, rain, the flight of birds, and trains. ${ }^{5}$

Not surprisingly, Klee took an interest in his son's early pictures. Felix recounts one instance:

I drew a rectangle on a sheet of paper and my father asked what it was. My answer was: 'That's Uncle Fritz.' To which my father replied: 'Yes but where is Uncle Fritz? I don't see him anywhere on the paper.' I answered: 'Well, you know, he's just this minute gone out.' 6

This humorous memory illustrates that Klee was not only interested in his son's development, but in the thoughts behind Felix's picture making. Felix's matter-of-fact reply to his father's question demonstrates how young children think and view their surroundings differently than adults, ideas that psychologists like Piaget and Freud, for example, had been investigating in this period. ${ }^{7}$

${ }^{3}$ See the "Felix Kalendar" in rear of Klee, The Diaries.

${ }^{4}$ Klee, The Diaries, "The Felix Kalendar," October 28, 1908, 421; Klee, The Diaries, "The Felix Kalendar," entry 27, August, 1909, 424.

5 Klee, The Diaries, “The Felix Kalendar," entry 26, August 1909, 424.

${ }^{6}$ Felix Klee, Paul Klee: His Life and Work, 49.

7 See Piaget, The Child's Conception of the World (1929) (London: Routledge \& Kegan and Paul Ltd., 1971); see Sigmund Freud, Beyond the Pleasure Principle (1920), trans. James Strachey (New York: Bantam Books, 1963). 
A clear connection between Felix's memory and Klee's formal views on art is apparent in a 1924 lecture Klee gave in Jena. Klee states:

While the artist is still exerting all his efforts to group the formal elements purely and logically (...), a layman, watching from behind, pronounces the devastating words 'But that isn't a bit like uncle.' The artist, if his nerve is disciplined, thinks to himself, 'To hell with uncle! I must get on with my building (...) ${ }^{8}$

Klee almost directly borrowed the idea that his son gave him: that the images an artist (or child artist) creates have certain abstract meaning, beyond what an outsider viewer can often see. This abstract view, Klee goes on to state in the lecture, is key to understanding modern art: making the invisible visible. ${ }^{9}$

The idea that children think differently and more abstractly is confirmed in Klee's sensitive work, Movement Around a Child (1928) (fig. 39). In the image we are presented with a child with a large head around which lines revolve. Judging from this activity around the child's head, it could be determined that the child experiences his/her surrounding in a way that perhaps the adult is immune to, a notion that goes back to the German Idealist tradition, particularly in the writings of Schiller. ${ }^{10}$ A young child relies on the sensory - on the visual, on sound, touch or taste - rather than pre-existing notions. ${ }^{11}$ In this way, nature pulsates with novelty and excitement to a child. Klee's close associate at the Bauhaus, Kandinsky, also accepted the idea that children see the world as still fresh and stimulating. He states: "The world deeply impresses the child"

${ }^{8}$ Paul Klee, On Modern Art (London: Faber and Faber, 1948), 31.

${ }^{9}$ Klee, On Modern Art, 35.

${ }^{10}$ Schiller, "On Naive and Sentimental Poetry," Part 1.

${ }^{11}$ Helga Eng, The Psychology of Children's Drawings (London: Kegan Paul, 1931), see ch. 2; Viktor Lowenfeld, Creative and Mental Growth (New York: Macmillan and Co., 1947), see introduction. 
and calls for a re-incorporation of a childlike world-view in the artistic process. ${ }^{12}$

Movement not only reveals that children view the world differently, but that they are connected to a kind of cosmic consciousness. This assertion is determined through Klee's clear use of lines, circles, and colours, forms and techniques he regarded as filled with otherworldly energy. ${ }^{13}$ To Klee, lines emit energy and he conceived of the potential of lines to be infinite. ${ }^{14}$ Lines in motion especially achieve a kind of energy that even supersedes earthly phenomena and, in doing so, bridge out into the cosmic. ${ }^{15}$ In his Pedagogical Sketchbook, Klee defines dynamic lines as a pure artistic form that is able to "overcome" terrestrial reality by moving into "metaphysical spaces and (...) [past] physical limitations." "16 In Movement, lines appear to rotate, and therefore may achieve this cosmic connection.

Moreover, the lines move in a kind of circular, spiral manner. Klee considered circles to be cosmic in scope and defined them as the "the purest mobile form, the cosmic one." ${ }^{17}$ In Pedagogical Sketchbook we read that spirals can also bridge into otherworldly realities. They achieve this, according to Klee, through their infinite flow originating from a central point and progress outwards; this movement, Klee tells us, mimics the

${ }^{12}$ Wassily Kandinsky, "On The Spiritual In Art," in Post-Impressionism to World War II, ed. Debbie Lewer (Oxford: Blackwell Publishing, 2006), 101.

${ }^{13}$ Klee, Paul Klee: Pedagogical Sketchbook (1924), trans. Sibyl Moholy-Nagy (New York: Frederick A. Praeger, 1953), section I.5 -20. Klee also talks of the energy emitted from lines into the air, section III.27-48.

${ }^{14}$ Klee, Pedagogical Sketchbook, I.5 -20, III.27, IIII.43; In Pedagogical Sketchbook, section IIII.37, Klee tells us lines can move through metaphysical spaces and physical limitations.

${ }^{15}$ This notion is gleaned from the introductory sentence in his chapter on lines: "But there are regions with different laws and new symbols, signifying freer movement and dynamic position." See Klee, Pedagogical Sketchbook, section III. 26.

${ }^{16}$ Klee, Pedagogical Sketchbook, section I.5, 20, III.27, IIII.37, IIII.43; See also MoholyNagy's introduction to the text, 12.

${ }^{17}$ Klee, Pedagogical Sketchbook, section IIII.35- 36. 
continuous nature of the universe. ${ }^{18}$ Such spiral linear movement appears in Movement and reflects Klee's view of children's cosmic awareness as a link to higher possibilities.

Finally, the colours that serve to separate these lines also relate to this higher interpretation of the unseen "movement" around children. In Kandinsky's On the Spiritual in Art, colours are presented as "spiritual vibrations" that resonate harmoniously with the soul - harmony that is especially captured in the colours red and blue which we find in Movement. ${ }^{19}$ According to Kandinsky, the colour red "may cause a spiritual vibration like flame, since red is the colour of flame."20 Tones of blue represent spirituality and awaken the desire for the eternal in the human soul. ${ }^{21}$ In a lecture of 1922, Klee encouraged his students to refer to On the Spiritual in Art for their colour education, thereby giving Kandinsky's spiritual value of colours formal importance in his own classroom. ${ }^{22}$ In line with this view, the articulation of blue and red tones in Movement could surely suggest that Klee viewed children's cosmic mental processes as tied to spiritual energies.

While Movement Around a Child identifies the unseen and mystical thought processes of children, an earlier work, Mystical-Physiognomic (1924) (fig. 40), explores this theme through children's physical features. In this case, Klee maps out the features of a child's face using intricate diagrams of lines, suggesting a meticulous methodology to this investigation. In this study, Klee focuses on the eyes, symbolically referring to the child's mystic vision.

${ }^{18}$ Klee, Pedagogical Sketchbook, IIII.35-36.

${ }^{19}$ Kandinsky, "On the Spiritual in Art," see part II, "About Painting," 24.

${ }^{20}$ Kandinsky, "On the Spiritual in Art," part II, 24.

${ }^{21}$ Kandinsky, "On the Spiritual in Art," part II, 24, 36-37.

22 Klee, The Nature of Nature, lecture of Tuesday, 28 November 1922, 467. 


\section{Mysticism in the Play of Children}

\section{Child's Play}

Another area where we can trace Klee's cosmic and spiritual view of children is in their play. Klee's early interest in play is largely characterized by a witty, ironic, and satirical humour. ${ }^{23}$ For example, his well-known Two Men Meet: Each Supposing The Other To Be of Higher Rank (1902) (fig. 41) is amusing in its critique of social hierarchy. ${ }^{24}$ Klee would employ a very different type of playfulness in his formal practise during the years at the Bauhaus (1920-1931). ${ }^{25}$ I will argue that the root of the playfulness in this period was children's play, an activity that could access immense energy and would even allow Klee to engage in this metaphysical connection, as he does, for example, through his puppets.

The German Idealist tradition presents childhood as a period of sensitive vision, and play is viewed as one of the inherent powers of childhood. ${ }^{26}$ Schiller, for instance, places value on a type of play that combines the sensual and the imaginative with the intellect. In On the Aesthetic Education of Man, Schiller powerfully states that poetic genius is achieved through play and that "Man plays only when he is in the full sense of the word a man, and he is only wholly Man when he is playing." 27 This play, Schiller tells us, can only be arrived at through a return to a childlike sensibility or the "naïve way of

${ }^{23}$ From as early as 1902 , Klee connected artists with play. He wrote: "play, delude yourself and others, be an artist." See Klee, The Diaries, Diary III, entry 422, 1902, 123. ${ }^{24}$ Klee's use of satire and irony is widely known and accepted. One source for this element in his work is Franciscono, Paul Klee: His Work and Thought, 130.

${ }^{25}$ Werckmeister, "The Issue of Childhood," 143.

${ }^{26}$ Klee's notion of play harks back to idealist aesthetic writings, an issue noted in passing by Werckmeister, "The Issue of Childhood in the Art of Paul Klee," 143.

${ }^{27}$ Schiller, On the Aesthetic Education of Man, 80. 
thinking" which "belongs only to children and childlike-minded men."28 While Klee indeed valued a synthesis of the sensual with reason in artistic production, he also directly appreciated the spontaneous play of children.

In his pedagogical writings, Klee suggests how children's play could allow artists to access new creative frontiers. Klee lectured to his students in 1921, for example, that the line should incorporate "the chaotic ways of the first play." 29 Klee continues in the lecture to describe the imaginative nature of children's playful pictures, or what he calls "first-play drawings." ${ }^{30}$ Klee states that children are excited when they discover that lines can move and resemble things, an excitement that "is hard for us grown-ups to understand (...) [once] criticism sets in (...)"31 Nonetheless, Klee advised his students to attempt to re-incorporate in their work the playful creativity known in their youthful pictures. $^{32}$

Moreover, Klee viewed colour tonality in terms of play and lectured his students on the idea that colours relate to each other in "a playful game of spreading out and foregathering again." 33 According to Klee, the creation of form is also a process of play since it is an interaction between lines, dots, and elementary shapes and the empty canvas or page. ${ }^{34}$ In these interactions, the "elementary creative process [children's creative

${ }^{28}$ Schiller, On the Aesthetic Education of Man, 6.

${ }_{29}$ Undated lecture notes as published in Paul Klee Das bildnerische Denken, $3^{\text {rd }}$ Edition (Basel, 1911), 103.

${ }^{30}$ Klee, The Thinking Eye, lecture from November of 1921, 103.

31 Klee, The Thinking Eye, lecture from 1921, titled "line: active, middle, passive," 103.

${ }^{32}$ Klee, undated lecture notes as published in Paul Klee Das bildnerische Denken, 103.

${ }^{33}$ Klee, The Nature of Nature, lecture of December 4th, 1923, 109.

${ }^{34}$ Klee, "Creative Credo," 5-10. 
process] must be kept tacitly in mind." the formal mechanics of motion through the movement of children's toys:

The top (...) every child knows that a top does not fall as long as it remains in motion, as long as it spins (...) We can derive equal comfort from [the spin of] a child's hoop. ${ }^{36}$

\section{The Free and Creative Play of Children}

Klee appreciates the freely creative and natural play of children as opposed to when it is controlled in a school setting. In 1902, Klee wrote to Lily Stumpf about the "wriggling things" with "young faces" on a school outing, pushing one another in an almost malicious way. ${ }^{37}$ The clearly troubled account has been interpreted by Helfenstein to indicate Klee did not always idealize children as "pure" and "innocent." 38 Similar to Rousseau's idea that children should be allowed to play freely, Klee's account of the children on a school outing can also be read as an expression of the repercussions in removing children from their natural states of play.

The unnatural play that results from conformity and socialization is expressed in Klee's 1913 Children as Actors (fig. 42). ${ }^{39}$ In the simplistically rendered image, child figures are lined up and wear costumes as if on a stage. There is something unsettling and miserable about their faces. Conceivably these children, in their imitation of adults, have become unnatural, an idea reminiscent of Klee's 1911 statement that children

${ }^{35}$ Klee, The Nature of Nature, lecture of Tuesday, January 15, 1924, 385.

${ }^{36}$ Klee, The Thinking Eye, lecture of Monday, March 20, 1922, 384-5.

${ }^{37}$ Klee, The Thinking Eye, lecture of August 6, 1921; See also Osterwold, Paul Klee, 180.

${ }^{38}$ Helfenstein, "The Issue of Childhood in Klee's Late Work," 139.

${ }^{39}$ Werckmeister also acknowledges Children As Actors and the idea that the children are acting, not being natural, see "The Issue of Childhood in the Work of Paul Klee," 143. 
become corrupted when they begin to imitate the external (see chapter one).$^{40}$ By contrast, Klee valued the natural and spontaneous play of children. As early as 1905, for example, in a letter to Stumpf, Klee wrote that he was pleased with his etching of two children who were not inundated with philosophy or literature but occupied themselves simply with toys. ${ }^{41}$ While this etching is no longer extant, Franciscono has related this quote to two works from around the same time, Girl with a Doll and Paul and Fritz. (1905) (figs. 43 and 44), where children are depicted as playing naturally. ${ }^{42}$ Klee's Children As Actors, therefore, gives expression to his conviction that children lose their inherent and creative energies when they "act" like adults.

\section{Mysterious and Cosmic Energy in Children's Free Play}

During the 1920 's, Klee created a large number of works that exhibit an interest in the positive aspects of child's play. ${ }^{43}$ Often these works suggest that children's play can access mysterious energy. For example, in his 1928 Children at Play Forming a Chain (fig. 45), Klee depicts five children occupied in blissful play where they hold hands in a row. The children are forming a chain, uniting together as if they are about to break out

${ }^{40}$ Klee, Schriften, Rezensionen und Aufsätze, 97.

${ }^{41}$ Klee to Lily Stumpf, 1905, as quoted in Werckmeister, "The Issue of Childhood," 139140.

${ }^{42}$ Franciscono, "Paul Klee and Children's Art," 97.

${ }^{43}$ Some of Klee's works that focus on child's play can be found in the Paul-KleeStiftung ed., Paul Klee Catalogue Raisonne, vol. 1-9: Children at play forming a chain (1928), cat. rai. no. 4721; Children Playing Sport (1928), cat. rai. no. 4746; Group of Little Girls (1929), cat. rai. no. 4760; Action Between Children (1928), cat. rai. no. 4726; Child with Toy (1907), cat. rai no. 308; Girls Playing Outside (1908), cat. rai. no. 347; Sketch from the Children's Play (1926) and a copy, cat. rai. no. 4145, 4146; Toys (1927), cat. rai. no. 4485; Girl with Doll (1930), cat. rai. no. 5367. 
into song, which indicates that the natural play of children is harmonious and pure. One child even stands on his/her head.

The inclusion of the numerous specks or dots in the foreground is particularly noteworthy. Dots, to Klee, are the stationary state of lines ("a line is a dot that went for a walk") and they are a "point of progression" before taking on movement. ${ }^{44}$ Dots are "energy center[s] charged to the highest degree;" they are seeds of growth that hold unlimited possibilities. $^{45}$ In a lecture of 1921 , Klee even relates dots to the primordial and the cosmic: "Certain things have primordial motion. The point is cosmic, a primordial element." ${ }^{46}$ The inclusion of dots around the children playing, thus suggests that Klee attributed a certain energy around their activities that is at once infinite, cosmic and primordial.

Child with Skipping Rope (1925) (fig. 46) also presents a child's delightful play as directly connected to mysterious energies. In the image, a girl is shown skip-rope jumping. As in Children at Play, Klee includes these dots or points. In this case, however, they are even more numerous. Given Klee's views on dots, their appearance in Child with Skipping Rope may refer to the high levels of energy emitted in the girl's active jumping which cannot be seen in visible reality.

A passage in Klee's Creative Credo reinforces the interpretation of children's play as a way to access higher energies. It reads: "Art plays an unwitting game with the last things and yet attains them." 47 Werckmeister has analyzed this statement and interpreted "last

${ }^{44}$ Klee, The Pedagogical Sketchbook, section I. 1-16.

${ }^{45}$ Klee, The Nature of Nature, lecture from Monday, November 5, 1923, 25; see also undated lecture notes, The Nature of Nature, 31, 215-219.

${ }^{46}$ Klee, The Thinking Eye, linear-active lectures of 1921, 105.

${ }^{47}$ Werckmeister, "The Issue of Childhood," 143. 
things" to mean resurrection and death; "unwitting game" he interprets as referring to German idealist aesthetics and play. ${ }^{48}$ Werckmeister has also noted that this line was revised by the artist before its publication to eliminate some direct references to childhood. ${ }^{49}$ The original line reads:

[Art] plays an unwitting game with things. As a child imitates in his play, we imitate in [our] play the forces which created the world and are [still] creating it. ${ }^{50}$

Despite the external factors and pressures which may have lead to the alterations, outlined by Werckmeister, Klee's revision of his earlier text brings two facts into focus. First, the "unwitting game" refers not only to play, but also to children's play. ${ }^{51}$ Second, there is an unmistakeable metaphysical element in this connection of imitating the play of children to "last things," to death and resurrection, and to the idea of higher forces like the creation of the world. The revised version, taken together with the original, indicates that Klee viewed these concepts as intertwined and linked. While children lose these inherent qualities in the imitation of adults - expressed in Children As Actors - Klee tells us by contrast that adults who imitate the play of children, imitate an act of a higher value. These ideas are further confirmed later in the passage of Creative Credo where Klee states that through play and fantasy, one could:

Transport (...) to another world (...) [where you] can slough off your earthly skin, to fancy for a moment that you are God (...) [a] soul (...) to a banquet in order to nourish its starved nerves $(\ldots)^{52}$

In mimicking children's fantastical play, one can connect to other-worldly forces to find nourishment and higher meaning.

${ }^{48}$ Werckmeister, "The Issue of Childhood," 143.

${ }^{49}$ Werckmeister, "The Issue of Childhood," 143.

${ }^{50}$ Klee, "Graphik," in J. Glaesemer, ed., Paul Klee. Das graphische und plastische Werk (Berne: Paul-Klee-Stiftung, 1975), 17.

${ }^{51}$ Werckmeister, "The Issue of Childhood," 143.

${ }^{52}$ Klee, "Creative Credo," 9-10. 
These higher elements of children's play can be interpreted further through Klee's numerous puppets, all of which were completed between 1916 and $1925 .{ }^{53}$ Felix's wish for his own hand puppets would not necessarily have led his father to make the figures himself. Christine Hopfengart has noted that it had been possible for some time to buy manufactured puppets intended for private household theatres. ${ }^{54}$ Klee, rather, had long enjoyed being involved in Felix's play and had made him numerous toys. ${ }^{55}$ Felix recounts that he was so enthusiastic about Punch and Judy shows as a child that his father was happy to indulge him and set about adding to Felix's world of puppet play with over fifty figures. ${ }^{56}$ Perhaps Klee's preoccupation with creating puppets for Felix was due to his own fascination with them. According to Klee's sister, Mathilde, as a child he enjoyed performing with puppets in his family circle. ${ }^{57}$ Klee may have also created the puppets, Osterwold argues, to turn inwards to family life and the world of fantasy in the context of the First World War, and in the economic instabilities that followed. ${ }^{58}$

Klee's puppets, all of which are highly original and playfully imaginative, along with the corresponding theatre that he built (fig. 47), could be seen as a way in which the artist fused his ideas about childhood, art, and play with the act of child's play itself. The

${ }^{53}$ Christine Hopfengart, "Hybrid Creatures - Klee's Hand Puppets Between Art and Kasperl Theater," in Paul Klee Hand Puppets, ed. Andreas Marti (Zentrum Paul Klee, Bern: Hatje Cantz, 2006), 8-31.

${ }^{54}$ Hopfengart, "Hybrid Creatures," 22.

${ }^{55}$ Felix Klee, "Erinnerungen an meinen Vater" in Paul Klee, exh. cat. Staatliche Kunstsammlungen Dresden (Dresden: Albertinum/Kupferstich-Kabinett, 1984), 9; See also Hopfengart, "Hybrid Creatures," 18.

${ }^{56}$ Felix Klee, Paul Life: His Life and Work in Documents, 49; Hopfengart, "Hybrid Creatures," 22. Klee created about fifty figures but only thirty survive today.

${ }^{57}$ Hopfengart, "Hybrid Creatures," 12.

${ }^{58}$ Osterwold, Paul Klee, 12, 96. For more information on puppets, see Eileen

Blumenthal, Puppetry: A World History (New York: Harry N. Abrams Inc., 2005), 2021, 111-112. 
puppets and theatre engaged in play could be viewed as a kind of artistic ideal for Klee as an artist who was particularly fascinated with childhood and child's play. While in active play, Klee's work would participate in the creative action entirely reliant upon the child (Felix) playing. Perhaps in this way, Klee's work could even be involved in that mysterious energy he viewed children's play as able to access.

Particularly significant to my more metaphysical interpretation of these playthings is Klee's self-portrait puppet constructed out of plaster and a beef bone (1922) (fig. 48). ${ }^{59}$ Klee's grandson, Aljoscha Klee, has shown that the puppet corresponds precisely to Klee's appearance at the time: the black astrakhan cap and even Klee's old suit were used for the clothing. ${ }^{60}$ Harking back to a German Romantic tradition that placed importance on the eye as indicative of introspection, Klee gives the puppet strikingly wide-opened eyes, which suggests that Klee viewed himself as a seer and visionary. ${ }^{61}$ Presumably the eyes were intended to convey that Klee probed deeply into his own being.

It is interesting, however, that Klee presents this idea of himself in a child's toy figure. Aljoscha Klee did not understand the reason that Klee made a puppet self-portrait; in fact he was confused by the figure. The wide-eyed self-portrait, however, is especially in line with Klee's ideas about children's cosmic consciousness and the "higher" nature of their

${ }^{59}$ Felix Klee, "Paul Klee: Hand Puppets" in Paul Klee Hand Puppets, ed. Andreas Marti (Zentrum Paul Klee, Bern: Hatje Cantz, 2006), 46.

${ }^{60}$ Aljoscha Klee, "Felix Klee and the Puppet Theater," in Paul Klee Hand Puppets, 41.

${ }^{61}$ See Mitchell B. Frank, German Romantic Painting Redefined: Nazarene Tradition and the Narratives of Romanticism (Aldershot: Ashgate Press, 2001), 39. Frank discusses how German Romantic artists placed value on vision and notes, for example, that Caspar David Friedrich's Self-Portrait (1810) presents an intense cast of the eyes to "signify an introspective type of person, one who probes deeply into his inner being." 
play. ${ }^{62}$ Klee created himself in puppet-form to enter (or re-enter) the world of child's play - play that Klee ascribed great importance to in his pedagogical sketchbook and his Creative Credo. In the realm of puppet theatre, Klee's actions rely upon the wishes of the child playing and in this way he is able to participate in the "unwitting game with the last things" or connect through child's play to cosmic energies. As such, Klee's puppet resounds powerfully as a culmination of all that he had been leading up to in his deep investigations of children's play: to be actively involved in a child's unmediated play process.

Moreover, the use of the beef bone, an element not present in many of the other puppets, shows the special care Klee took in his self-presentation. The bones tie the puppet to carnal realties of life; a physical body that is bound to earthly phenomena and mortality. As much as Klee saw himself as a visionary, bridging out into the metaphysical processes of the universe through childhood and child's play, he was tied to flesh, bones, and human (or adult) realities.

\section{The "Once Upon a Time" or Fantastical Childhood-Element in Klee's Work}

Franciscono has stated that some of Klee's work has whimsical and fantastical undertones, and writer A. S. Byatt has also described Klee as an artist who depicts a kind of "fairy-tale landscape." ${ }^{63}$ While Klee's interest in fantasy has been acknowledged in

${ }^{62}$ Aljoscha Klee, "Felix Klee and the Puppet Theater," 41. Aljoscha states, "What Klee's intention was with this portrayal and what relation it had to the other figures, to his own life or his art in general, will no doubt remain a mystery."

${ }^{63}$ Susanna Partsch, Paul Klee, 1879-1940 (Köln: Taschen Basic Art, 1993), 42. Partsch writes that several of Klee's works "remind us of a fairy tale;" Franciscono, Paul Klee: His Work and Thought, 13; A. S. Byatt notes that there is a "fairy-tale world" in Klee's 
the scholarly literature, it has not been examined literally in relation to children's fairy tales. The author C. S. Lewis (1966) and the literature historian Diana Waggoner (1978) have characterized fantasy in the early years of the twentieth century as a space largely for children where uncapped imaginations reigned. ${ }^{64}$ Magic and mysticism are the norm in this world of fantasy, along with the existence of fairies, elves, and happy endings. ${ }^{65}$ While adults are encouraged or obligated to put fantasy away with childish things, Klee, I will argue in this section, turned to fantasy during his years as a Bauhaus Master in a search for artistic and spiritual meaning. ${ }^{66}$

While studying Classical and Renaissance art in Rome, Klee recognized that folk tales and fantasy stories were prerogatives of children. Klee wrote that in order to accept the artifices of civilization, his academic art-training, and the world of the educated adult, he would have to bid farewell to his beloved fairies:

What a change within me. I have seen a piece of living history. The Forum and the Vatican spoke to me. Humanism jumps at my throat; it is more than an invention of high school teachers to torture their students. I must go along with it, if only for a little way. Farewell, elves, moon fairy, star dust (...) Enough of magic! Here is neoclassical Europe! ${ }^{67}$

Klee suggests that in order to accept rationality and the Italian "foundations" of art, he must leave behind Nordic German notions (fairy stories, magical forests). Despite this

work in her introduction to The Annotated Brothers' Grimm, ed. Maria Tatar (New York and London: W. W. Norton and Company, 2004), xix.

${ }^{64}$ C. S. Lewis, "On Juvenile Tastes," in Of Other Worlds (New York: Harcourt, Brace \& World, 1966), 41; Diana Waggoner, The Hills of Faraway: A Guide to Fantasy (New York: Atheneum, 1978), see introduction.

${ }^{65}$ Lewis, "On Juvenile Tastes," 41.

${ }^{66}$ The line, "put away with childish things" is a Biblical reference. See 1 Corinthians, 13:11, King James Bible.

${ }^{67}$ Klee, The Diaries, Diary III, 1902, entry 413, 120. 
soliloquy, however, Klee soon returned to fairy tales and children's stories in his work and therefore he did only "go along with it [adult things] (...) for a little way."

Klee had documented his general appreciation for children's fantasy through his life. ${ }^{68}$ As a child he read "with special pleasure" Adolf Wilbrandt's Der Gast vom Abendstern, a fantastical tale about a visitor from planet Venus. ${ }^{69}$ Of the Märchenoper (fairy-tale opera) "Hänsel und Gretel,” Klee reports that he saw the show at least twice (once as a child and then again in his early twenties) and he mentions the experiences in his diary. ${ }^{70}$ In 1917, while serving in the German military, Klee wrote to his son Felix: "My dear little fellow...I often read your beautiful book of tales." ${ }^{71}$ Likely these tales were children's fairy tales and Klee relates in the letter that he still enjoyed them in his adult age. What is more, Klee's interest in Märchen and their elements (magic, fairies, elves, and witches) appears in several of Klee's diary entries. ${ }^{72}$ Klee used these terms to describe his surroundings and various encounters with people. Even some of Klee's recorded dreams have a kind of fairy-tale quality. In 1906, for example, Klee dreams that he visited a magician in his garden. ${ }^{73}$ These idiosyncratic experiences, along with Klee's general appreciation for fairy tales, take expression in many of the artist's works of the 1920s - precisely concurrent with Klee's years at the Bauhaus. Despite the new

${ }^{68}$ Klee, The Diaries, Diary III, 1902, entry 424, 123.

${ }^{69}$ Klee, The Diaries, Diary I, "Memories from Childhood," entry 37, 11-12.

${ }^{70}$ Klee, The Diaries, Diary III, 1904, entry 546, 148.

${ }^{71}$ Klee, The Diaries, Diary IV, 1917, entry 1076a, 371.

${ }^{72}$ For instances of Klee's use of words like fairy-tale, witch, fairy, naïve, etc., see The Diaries, Diary II, 1902, entry 369, 88; Diary II, entry 399; Diary III, entry 566/567. ${ }^{73}$ See Klee, The Diaries, Diary III, entry nos. 566, 567, 576 for the word "bewitching," no. 88,7413 , and no. 62 for "magic," no. 413 for "fairies" and "elves;" see also The Diaries, Diary III, 1906, entry 762, 199. 
push for professionalism, therefore, the Bauhaus Master placed importance on a topic largely viewed as frivolous by the average adult.

\section{Fairy Tales in Klee's Work}

In addition to his well-known Hoffmannesque Fairy Tale Scene (1921), Klee would execute countless works that deal with fantastical subject matter (witches, magic, elves, dragons, gnomes or fairies). ${ }^{74}$ The title of Klee's 1920 watercolour, for example, There Once was a Child Who Never Wanted (fig. 49), resembles the classical opening line of many fairy stories. In the image a child with bright blue eyes and rosy cheeks - signifiers of innocence - stares out at the beholder in an almost helpless manner. The background's geometric character is consistent with Klee's style at the time, whereas the bright colours convey the hyperrealism of a far off, fairy-tale reality. Klee's slightly comedic title suggests that most children want for things and, ironically, once upon a time, in a far away place, there lived a child who never wanted. Alternatively, this work could simply be the beginning of a fairy story about a selfless child, as in Cinderella, where oppressors (i.e. step-sisters, step-mothers, witches) are eventually reprimanded for their want, greed

${ }^{74}$ Selected examples of fairytale-inspired works are found in the Paul-Klee-Stiftung ed., The Paul Klee Catalogue Raisonne, vol. 1-9: Animal Fable (1924), no. 3409; Hoffmanneque Tale (1921), no. 2609; Hoffmannesque Fairy-Tale Scene (1921), no. 2714; Ride on the Ogre (1923), no. 3300; Tale (1930), no. 5397; Frightens Even Witches, (1926), no. 4044; Fairy Tale (1929), no. 4888; Mermaid Under Water (1921), no. 2801; Ancient Fable (1923) no. 3149; A Witch's Glance (1923), no. 3292; Fairy Tale Picture (1924), no. 3557; Fairy Tale of the Dwarf (1925) no. 3937; Lady of the Castle (1919), no. 2184; Bewitched! (1922), no. 3068; Dancing Witch (1922), no. 3049; Fright of a Witch (1922), no. 3031; Fairy Tale of Three Large Flowers (1928), no. 4632; Memorial to the Witch (1922), no. 3052; A Witch Threatens Four Children (1922), no. 3037; When They Do Not Believe in it Anymore (1927), no. 4473; Mr. Jules, The Magician (1920), no. 2499; Magic Theatre (1923) no. 3118; Magical Experiment (1920), no. 2399; Fairytale picture with Lake and Steamboat (1919) no. 2162. 
and wrongdoings against the child hero/heroine. Bruno Bettelheim, in his Uses of Enchantment, confirms these ideas. Bettelheim notes that, in fairy tales, selfless, honest and true characters generally win out over evil forces. ${ }^{75}$

Other works specifically reference encounters with witches. These are the largely evil figures who make mischief, create havoc, and inflict harm on these selfless characters. Brewing Witches of 1922 (fig. 50) depicts two witches grinning before a cauldron and they appear to be chanting hexes or casting spells over a potion. This image of the conniving witch brewing away at some poisonous substance connotes witches in fairy tales, such as in the Grimm Brothers' Snow White. ${ }^{76}$ This theme is carried into A Witch Threatens Four Children (fig. 51) and Witch Dispatching Her Animals (fig. 52), two works where Klee references fairy stories while, at the same time, draws from a child's visual vocabulary. A Witch Threatens Four Children could easily be a child's schematic picture of a fantasy scene where a group of children are preyed on by a witch, while Witch Dispatching Her Animals reflects a child's style in the scribbled, unrefined lines and in the fantastical subject matter of witch-controlled animals set out upon the world. Klee's presentation of these notions through a childlike aesthetic suggests he sought to find a consistency in form and content.

${ }^{75}$ Bruno Bettelheim, The Uses of Enchantment: The Meaning and Importance of Fairy Tales (Alfred A. Knopf: New York, 1976), 6-11.

${ }^{76}$ See Grimm, "Snow White" in The Annotated Brothers Grimm, 240-255. 


\section{The Deeper Meanings in Fantasy}

Klee's treatise on the formal properties of modern art, Creative Credo, begins with the phrase: "Let us take a little trip into the land of deeper insight."77 In the work, Klee tells a story about a group of travelers who embark on a great journey to find meaning and higher insight. During the ordeal, the travelers must overcome their greatest fears. Immediately the story is reminiscent of a fairy tale and also has many parallels to Goethe's Das Märchen (The Fairy Tale). ${ }^{78}$ Das Märchen's central plot revolves around the crossing of a river, representing the divide between the outer life of the senses and the ideal aspirations of the inner human quality or soul. Similarly, Creative Credo is based on the crossing of a river. Klee's river represents the obstacle that stands between the characters in his tale and "the land of deeper insight."79 In Klee's tale, he, the other characters, and we, the audience, set out on a journey to cross the river:

After a short time, we (...) stop to catch our breath (...) I look back to see how far we have come (...) Ponder the distance thus far traveled...[come to] a river (...) [over which] we use a boat (...) On the other bank we encounter someone who, like us, wishes to deepen his insight. ${ }^{80}$

Klee's fable-like analogy carries on until he and the other travelers encounter a storm, and are forced to face their "inhibitions, nervousness (...) [and] repressed anxieties" before the "happy ending" which "serves as a guiding thread even in the dark woods." This tale has direct correlations to fantastical journeys embodied in children's literature.

${ }^{77}$ See Klee, "Creative Credo," in The Inward Vision, 5; Many examples of this opening line can be found in the Grimm Brother's Tales, see Maria Tatar ed. The Annotated Brothers Grimm (New York: W.W. Norton and Co., 2004).

${ }^{78}$ Johann Wolfgang von Goethe, The Fairy Tale of the Green Snake and the Beautiful Lily (1795), trans. Donald Maclean (Grand Rapids, MI: Phanes Press, 1993).

${ }^{79}$ Klee, "Creative Credo," 5.

${ }^{80}$ Klee, "Creative Credo," 6.

${ }^{80}$ Klee, "Creative Credo," 5-6.

${ }^{81}$ Klee, "Creative Credo," 6-7. 
For example, in Hänsel and Gretel, two children are abandoned in a forest and are threatened by a cannibalistic witch whom they ultimately face and kill by way of her kitchen oven. Afterwards, the children had developed new insights into how to navigate back through the previously treacherous woods and return home. Similarly, Klee's characters face their fears, and their tale's happy ending ensures them "a guiding thread" home through the dark woods.

What is particularly fascinating about Creative Credo is the fact that Klee includes himself and the audience in the fable. Klee wanted to bring people with him to this mystical place, to travel with him to "the other side" of the river and share in the experience. Afterwards, we return to tell the tale enlightened or perhaps enchilded.

Fantasy was important to Klee in artistic creation because it offered fresh and exciting possibilities. Klee explored fantastic realms in the hopes of gaining new artistic vision and even transcendence. Consider the conclusion of Klee's Credo:

[F]antasy $(\ldots)$ creates illusory states which somehow encourage or stimulate us more than the familiar natural or known supernatural states (...) Let yourself be carried on the invigorating sea, on a broad river or enchanting brook, such as that of the richly diversified, aphoristic graphic art. ${ }^{82}$

Klee sought to be carried on the "invigorating sea," across to a child's space of fantasy where fables and fairy tales are the norm. Fantasy would stimulate us in that we could return to the familiar renewed and full of fresh insights for new artistic possibilities.

Inherently fairy tales deal with serious and terribly distressing subject matter. In this way they impart valuable moral clues and bridge the fantastical to the unfortunate realities of life. As such, fairy stories are journeys into the existential, as confirmed by the writings of C. S. Lewis. For Lewis, fairy tales are "spiritual explorations" and hence

${ }^{82}$ Klee, Creative Credo, 11. 
"the most life-like" since they reveal "human life as seen, or felt, or divined from the inside. ${ }^{, 83}$ Schiller had recounted a similar idea: "Deeper meaning resides in the fairy tales told to me in my childhood than in the truth that is taught by life." ${ }^{.4}$ It was not the fairy tales themselves that were the source of meaning for Schiller. He longed, rather, to hear about these fantastical possibilities in the mysterious state of childhood, when life was perhaps still fresh and full of promise. Moreover, according to philosopher Henri Bortoft, one of Schiller's main concerns in his Letters on the Aesthetic Education of Man centered around the idea that through the soul, the human being could lead a truly worthy existence, yet it would have to come from the inside. ${ }^{85}$ Goethe, Bortoft tells us, found much pleasure in Schiller's Letters and set about writing a fairy tale - Das Märchenthat would reveal how the human soul could become whole and free. ${ }^{86}$ To Lewis, Schiller and Goethe, it seems, children's fairy tales could deepen understanding of earthly existence and connect the soul to a sense of higher purpose.

\section{Fantasy Meets Reality}

While Klee so confidently proposes the fantastic world of the fairy tale as key to authentic artistic vision in Creative Credo, he nevertheless came to view it as an unachievable goal and as a kind of ultimate tragedy. Klee's Ironic Fairy Tale of 1925 (fig. 53) is a particularly expressive and meaningful work in this context. In the image a

${ }^{83}$ C. S. Lewis, The Allegory of Love (Oxford: Oxford University Press, 1936), ch. VII, "The Faerie Queen;" see also Bettelheim, The Uses of Enchantment, 24. ${ }^{84}$ Schiller, "The Piccolomini" in The Complete Poetical Works, ed. Samuel Taylor Coleridge (Oxford: The Clarendon Press, 1912), section III, 4.

${ }^{85}$ See Henri Bortoft, The Wholeness of Nature - Goethe's Way of Science (Edinburgh: Floris Books: 1996), see section II, "Searching for a Living Perception of Wholeness." ${ }^{86}$ Goethe, as quoted in Bortoft's The Wholeness of Nature, see section II. 
personified moon presides over two figures with warped and ugly faces wearing elf-like hats that stand beside an organic form. Considering that the figures closely resemble the one in Klee's later work, The End of the Marionette (1927) (fig. 54), the two elflike characters in Ironic Fairy Tale may in fact be marionettes: fictional characters in a fairy tale. The moon represents the mystical forces of the universe, whereas the organic form in the center ties the figures to terrestrial reality. One figure reaches out to the moon wearing a pensive and dejected expression. He seems to be bordering on despair. The other figure holds a kind of fireball or blazing crystal. He stares hopefully at the ball as if the object will see him through whatever trials are to come. Klee seems to be suggesting here that this magic fireball is a key to the cosmos that will provide the figure with secret meaning. The other figure meanwhile is incomplete without it. At the same time, the moon appears to look down on the hopeful figure with a benign and expectant stare as if to say: "you will not succeed."

Perhaps the "irony" Klee refers to in the title lies in this maleficent moon. Klee had enjoyed as a child the story of "The Man in the Moon" from Hauff's Tales (1825): he states the story "pleased me mightily." ${ }^{, 7}$ The established Man-in-the-Moon character is a benevolent creature who guides and watches over children. ${ }^{88}$ In Ironic Fairy Tale, however, the moon takes pleasure in the despair or pitiable hopefulness of the characters he presides over. There is an unmistakable existential element to this ironic symbolism. Moreover, if in fact The End of the Marionette does relate to Ironic Fairy Tale, the tale

\footnotetext{
${ }^{87}$ Klee, The Diaries, Diary I, "Memories of Childhood" entry 37, 11-12.

${ }^{88}$ The Man in the Moon as a benevolent creature can be traced through a variety of traditions. For example, see its appearance in Dante Alighieri, Inferno, trans. Mark Musa (Bloomington/London: Indiana University Press, 1971), canto 20, line 126-129; See also a website on the various established legends, http://www.ianslunarpages.org/ Man_in_moon.htm.
} 
will end with the death of one of the characters. The story is not a fairy tale after all but a tragedy.

Bettelheim has shown that characters in fairy tales participate in stories that have simplistic existential dilemmas, which, more often than not, are happily resolved at the end. To Klee, adult life similarly proved more complicated than fairy tales or myths. As early as 1905 he wrote: "I am not Pan in the reeds, I am a man." ${ }^{89}$ Twenty years later, when The Ironic Fairy Tale was executed, Klee had been a Bauhaus Master for just under 5 years. He was starting to grow weary of the demands of his position around which he struggled to balance his own artistic practice. ${ }^{90}$ Art historians Constance Naubert-Riser, Frank Whitford, and Christian Geelhaar, have related how László Moholy-Nagy's influence changed the character of the Bauhaus. ${ }^{91}$ By 1925 the school was focusing less on German Expressionism and more on Constructivist styles, a shift Klee did not fully believe in. ${ }^{92}$ The remaining six years with the institution are characterized in the scholarly literature as a professional and existential struggle for the artist. ${ }^{93}$ While I do not wish to argue that Klee sought out the "dream-like" world of childhood to escape contemporary issues, as Osterwold suggests, it seems more accurate,

${ }^{89}$ Klee, The Diaries, Diary II, 1902, entry 421, 122-123.

${ }^{90}$ Jürg Spiller notes that by 1925 , Klee found it hard to combine creative work and teaching at the Bauhaus, and his interest waned, leading to him almost completely ending the recording of his lectures as he does in 1920-23. See Spiller's introduction to The Nature of Nature, 57.

${ }^{91}$ Constance Naubert-Riser, La Création Chez Paul Klee: Étude de la relation theoriespraxis de 1900 à 1924 (Paris: Éditions Klincksieck, 1978), 19-21; Whitford, Bauhaus, 47; Geelhaar, Paul Klee and the Bauhaus, 18.

${ }^{92}$ Naubert-Riser, La Création Chez Paul Klee, 19-21.

${ }^{93}$ Naubert-Riser, La Création Chez Paul Klee, 19-21; Whitford, Bauhaus, 47; Geelhaar, Paul Klee and the Bauhaus, 18. 
rather, to suggest that Klee began to realize the impossibility of his relentless quest for cosmic and spiritual beginnings in childhood. Ironic illustrates Klee's disillusionment. ${ }^{94}$

Through the story of the marionettes we come to realize the complexity with which Klee viewed fantasy. There will be times of hopefulness (the happy elf) - perhaps when Klee believes his art will bring him closer to higher realities - but there will also be suffering (the desperate elf) in adult life. In all this, there are uncontrollable elements laid out purposefully in the cosmos (the grinning moon), which is also expressed in Klee's Human Helplessness (discussed in chapter one). This sentiment is not only reflective of Klee's discontent at the Bauhaus, but of the growing pessimism in the "failure" of Modernization and Modernism to bring improvement to the world. ${ }^{95}$ Importantly, Klee's Ironic Fairy Tale relates something about Klee himself: he no longer was a child and he never could be one again; he could not access the beginning, or the spiritual "in-between world."

This mixed interpretation of the attractive nature yet ultimate disillusionment of a child's fantasy world is confirmed in Klee's writings. On the one hand, the world of fantasy is important, legitimate, and accessible to Klee. He relates this in a lecture: "fantasy...this world of illusion is credible. It is situated in the realm of the human."96 On the other hand, Klee explicitly told his students that fairy tales are bound by the limits of human knowledge and experience:

We may say that fantasy (...) creates illusory states which (...) stimulate us more than the familiar natural or known supernatural states, that (...) symbols bring comfort to

${ }^{94}$ Osterwold, Paul Klee, 6.

95 Osterwold, Paul Klee, 6.

${ }^{96}$ Klee, The Thinking Eye, undated lecture note, 262. 
the mind $(\ldots)$ and make it known (...) that it is not confined to earthly potentialities

(...) But in the long run, even enhanced reality proves inadequate. ${ }^{97}$

Klee desired an understanding of a reality where fantasy was still valid. Ultimately this avenue of Klee's engagement with childhood gives body to both his ideal in seeking out fantastical realities and to his anxieties, to the pain of growing up, and of change. Klee was very much pre-occupied with children's fantasy, yet he relates here that it was ultimately unsatisfactory, and this also speaks to the idea that he could never truly access a child's sense of cosmic beginnings despite his relentless exploration of their fantastic worlds.

\section{Conclusions}

Bettelheim states: "only in adulthood can an intelligent understanding of the meaning of one's existence in this world be gained from one's experiences in it." 98 Klee's interest in childhood was indeed retrospective and intellectual. However, this interest became a breathtakingly spiritual exploration. For Klee, investigating the possibilities in childhood was a metaphysical journey towards meaning, artistic authenticity, and beginnings. Unlike Klee's Bauhaus colleagues in their individual spiritual quests - Kandinsky and Theosophy or Moholy-Nagy and Constructivism - Klee accessed something more intimate to himself: his "inner child."

Klee's journey in Creative Credo to the fantastical "other side" of the river as well as his investigations into children's cosmic mental states and the importance of play were all aimed towards an overarching spiritual pursuit. Klee explored the "movement"

${ }^{97}$ Klee, The Thinking Eye, undated lecture note, 262.

${ }^{98}$ Bettelheim, The Uses of Enchantment, 3. 
around children and he attempted to access these cosmically aligned energies through their play and fantasy. In this way, Klee sought to "make visible" a child's reality in adulthood and to expose their knowledge of an "in-between world." Ultimately, it was an impossible goal. However, his relentless explorations of the different themes of childhood examined in this thesis reveal that for Klee it was well worth the effort. 


\section{Conclusion}

An observer above the world or a child in the world's totality. Paul Klee

In this concluding chapter, I will reaffirm the central idea of this thesis that in Klee's view, children have access to a spiritual realm. For Klee, the exploration of childhood, fantasy and play was a pathway to the "in-between world," as he called it. I will also continue to examine the idea that Klee in the end could not access a child's sense of the otherworldly. I will then shift the focus to the continuing and more popular treatment of the theme of Klee and childhood. Specifically, I will look at how Klee's art is used in certain children's books and how the Paul Klee center in Bern, Switzerland (The Zentrum Paul Klee) accommodates children and children's art through evocative museum practices. This fostering of childhood at the gallery and the appearance of Klee's work in children's books reveal that the tradition of associating Klee with childhood continues to be upheld and celebrated.

\section{Paul Klee and the Spiritual in Modern Art}

As discussed above, scholars have tended to focus on Klee's artistic pursuits with respect to childhood as an exploration of the authentic and simplistic, as an alternative form of primitivism, and as a source upon which Klee based his reduction of form. In the literature, his link to the spiritual has been viewed in terms of his art process, as a metaphorical repetition of the process of Genesis and Creation. However, his metaphysical interests in art, such as his ideas of exploring cosmic realms and seeking

\footnotetext{
${ }^{*}$ Klee, The Diaries, Diary III, entry 713/714, 1905, 190.
} 
out an otherworldly consciousness, have not been connected to his deep fascination with childhood. ${ }^{1}$ This thesis has attempted to correct this view, to show that there is spiritual meaning in Klee's interest in childhood.

In his talk On Modern Art, Klee tells us that he is able to access otherworldly realms through art:

[Modern art] tries convulsively to fly from the earth and eventually rises above it to reality. Its own power forces it up, triumphing over gravity. If, finally, I may be allowed to pursue these forces, so hostile to earth, until they embrace the life force itself, I will emerge from the oppressively pathetic style [realism, Classicism] to that Romanticism which is one with the universe. ${ }^{2}$

Klee wanted to remain on course with Romanticism to achieve an aesthetic that conveyed a sense of higher meaning. In these aims to shake off earthly reality and the shackles of academic art, Klee turned to children because he believed that they effortlessly achieved communion with the universe and their art was directly expressive of such harmony.

The idea that Klee valued children and their art in this process is most particularly gleaned from the conversation between Klee and Lothar Schreyer, an exchange discussed above. Schreyer visited Klee's Bauhaus studio in 1923 and the two had a fascinating conversation about how their art was often negatively perceived as parallel to the insane, to "primitives," and to children. Schreyer put down his full recollection of Klee's response to the question of what these links ultimately mean in his work:

\footnotetext{
${ }^{1}$ For Klee's writings on the spiritual, see lecture notes from The Thinking Eye, November 14, 1921, 99-100; See also Klee, On Modern Art, 45; Fineberg, The Innocent Eye, 109; On the link between Klee and the metaphysical, see Sixten Ringbom, "Transcending the Visible: The Generation of the Abstract Pioneers," in The Spiritual in Art, 147, 150; Judi Freeman, "Chronologies: Artists and the Spiritual," in The Spiritual in Art, 406; See also Goldwater, Primitivism in Modern Art, 200-201.

2 Klee, On Modern Art, 43.
} 
All we can do is commit ourselves, sincerely and faithfully, to the shift of the consciousness that our generation has experienced or is experiencing. Just as I am doing, and as all of us here are doing. I say it often, but sometimes it isn't taken seriously enough, that in our time worlds have opened up which not everybody can see into, although they too are a part of nature. Perhaps it's really true that only children, madmen and savages see into them. I mean, for example, the realm of the unborn and the dead, the realm of what can be, might be, but need not necessarily be. An in-between world. At least for me it's an in-between world. I call it that because I feel that it exists between the worlds our senses can perceive, and I absorb it inwardly to the extent that I can project it outwardly in symbolic correspondences. Children, madmen and savages can still, or again, look into it. And what they see and picture is for me the most precious kind of confirmation. For we all see the same things, though from different angles. ${ }^{3}$

Children, like the insane and the "savage," could still access these other worlds, which

Klee sincerely believed to exist. Klee aspired to the spiritual level of children and even appreciated their creative images above his own. For example, Klee told Schreyer that "the pictures my little Felix painted are better than mine." Perhaps, as he states above, Klee valued his son's ability to access this otherworldly space - it was confirmation to him that it did indeed exist ("the most precious kind of confirmation"). However, there is a great irony in Klee's words: children can see into higher realms, but as a sane and modern European adult, he could not.

In the conversation, Klee also states that other artists could express the otherworldly in their art, or the spiritual in art, by different means. Schreyer and Klee agreed that Franz Marc saw deep into the spiritual through his sensitive awareness of animals. The two also discussed how Kandinsky saw into spiritual realms through abstraction, and Klee recognizes that his own work did not fully transcend into this space:

${ }^{3}$ Schreyer, Erinnerungen an Sturm und Bauhaus, 170-171; also quoted in Felix Klee, Paul Klee: His Life and Work and Documents, 184.

${ }^{4}$ See Schreyer, Erinnerungen an Sturm und Bauhaus, 168; also quoted in Felix Klee, Paul Klee: His Life and Work and Documents, 182. 
I fiddle away at the in-between world. But there are also worlds that aren't inbetweens. A man like Kandinsky looks far beyond the in-between world (...) Kandinsky looks into a world of pure light. ${ }^{5}$

This pure world of light - beyond "the in-between world" - was a realm that Klee wished to access and explore in his own art. Klee even lectures on this idea in an effort to encourage his students to seek out this source:

In the womb of nature, at the source of creation, is where the secret key to all lies guarded. But not all can enter. Each should follow where the pulse of his own heart leads. So, in their time, the Impressionists - our opposites of yesterday - had every right to dwell within the matted undergrowth of every-day vision. But our pounding heart drives us down, deep down to the source of all. What springs from this source, whatever it may be called, dream, idea or fantasy - must be taken seriously only if it unites with the proper creative means to form a work of art. ${ }^{6}$

Every artist, Klee tells them, will discover his/her own path to the source and they must, "dig deep and lie bare," in order truly to express it. ${ }^{7}$ For Klee, artists, like children, could access such truth, which he believed existed in these other worlds. Klee would combine a childlike vision with his own creative process in an attempt to arrive at truly authentic and meaningful works of art. As mentioned in chapter one, Klee believed that children's art should be taken seriously, that children can be instructive to us in this endeavour to peel back the layers of modernity in the search for primordial beginnings or a kind of spiritual inner sense; in other words, total authenticity. ${ }^{8}$

\footnotetext{
${ }^{5}$ Schreyer, Erinnerungen an Sturm und Bauhaus, 172; Also quoted in Felix Klee, Paul Klee His Life and Work in Documents, 184.

${ }^{6}$ Klee, The Thinking Eye, undated lecture note, 51.

${ }^{7}$ Klee, The Thinking Eye, undated lecture note, 69.

${ }^{8}$ Klee, Schriften, Rezensionen und Aufsätze, 97.
} 


\section{Klee, Childhood, and the Implications for this Study}

Klee's rich interest in childhood is an exceedingly compelling topic. Unlike other artists who were intrigued with children's pictures like Kandinsky, Gabriele Münter, Picasso, and Joan Miró, for example, Klee's appreciation of childhood is truly vast, intellectual, and deep. Klee not only borrowed from children's pictures in terms of subject matter and style, but he also incorporated in his work and artistic process a childlike sensibility aimed at accessing a child's sense of imagination. As we have seen, Klee attempted to reconnect to his childhood by adding his childhood pictures to his oeuvre along with a list of youthful memories to the front of his diaries in 1911. Topics relating to children like the wild child, play or fantasy, were also integral to his work. Klee's puppets and the theatre he made for Felix, completed with great care and detail, also act as evidence of his rich interest in childhood. Perhaps most profound in this engagement is Klee's incorporation of children's artistic devices into his formal pedagogy at the Bauhaus.

It should also be noted that Klee's diaries are filled with references to his own childhood:

As a child...the beauty of the landscape was quite clear to me (...) Now [as an adult] dangerous moments occur, in which Nature seeks to devour me (1902). ${ }^{9}$

This entry tells us that, as a child, Klee found he was able to interpret his surroundings with clarity and could appreciate a deep connection to nature, a connection that was lost to him in adulthood. ${ }^{10}$ Another example is from 1905:

${ }_{9}^{9}$ Klee, The Diaries, Diary III, entry 421, 1902, 122.

${ }^{10}$ For an alternate interpretation of this quote, see Michael Baumgartner, "Reducing the Contingent to its Essence': Paul Klee's Dialogue with Nature," in Paul Klee's Enchanted Garden, ed. Zentrum Paul Klee (Bern: Hatje Cantz, 2008), 24-45. 
I [had] a good moment in Oberhofen. No intellect, no ethics. An observer above the world or a child in the world's totality. The first unsplit moment in my life. ${ }^{11}$

Klee held the child's view to be still complete and whole, and one that resides on a similar level to a cosmic viewpoint.

Klee's interest in childhood can be traced to 1902, when he rediscovered his own childhood pictures, and especially after 1905 when he created etchings of children (Paul and Fritz or Girl with Doll, see chapter two). ${ }^{12}$ Through the 1910's, Klee would develop an even more simplified and schematic aesthetic that is reflective of a childlike style. ${ }^{13}$ However, it was during the years 1920 to 1931 , the period explored in this thesis, that the artist explored child art and themes of childhood more consistently and conscientiously. This heightened fascination with childhood coincides precisely with Klee's years as a Bauhaus professor. It may be the case that Klee was forced to "dig deep" for his ultimate artistic purpose as a result of the demands of the lecture hall. These new demands may have forced Klee to develop an aesthetic theory meaningful to him. Klee was indeed preoccupied with the existential, the otherworldly, and the operations of the universe during these years and he ultimately related these concerns to childhood and a childlike style.

Klee's investigations of childlike sensibilities did not end in 1931, though they did change significantly. Helfenstein and Franciscono discuss Klee's late work in relation to childhood and illustrate that the artist underwent a stylistic shift in the 1930's to one

${ }^{11}$ Klee, The Diaries, Diary III, entry 713/714, 1905, 190.

12 Osterwold, Paul Klee, 6; Werckmeister, "The Issue of Childhood in the Work of Paul Klee," 139-140; Fineberg, The Innocent Eye, 82.

13 Franciscono, "Paul Klee and Children's Art," 102-109. 
that expressed child violence and that expressed new levels of simplification. ${ }^{14}$ The shift is often attributed by scholars to a variety of factors: the artist's unease with the ascendant Third Reich; Klee's dismissal from the Düsseldorf Akademie due to Nazi closures (1933); the forced flight to Switzerland (1933); the onset of a chronic wasting disease (scleroderma, started in 1936); the fact that Klee's art was frequently disparaged in the German press; the embarrassment as a result of being included in the infamous Entartete Kunst (degenerate art) exhibition (1937); and the psychological affects that ensued with the ultimate outbreak of World War II (1939). ${ }^{15}$ To add to matters, Klee was not granted citizenship in Switzerland, his country of birth, until six days after his death, despite repeated attempts to secure this status for himself and his family. ${ }^{16}$

Despite these complexities, or perhaps due to them, Klee returned to children's art with a new passion in many of his final works, for example in his 1938 Childhood (fig. 55). Fineberg tells us that Klee's deep preoccupation with childhood in his last years reflects a breathtaking cycle of life that ends with a renewed interest in his own beginnings. ${ }^{17}$ It could be added that Klee turned to the theme of childhood in these final years because he desired to access children's sense of spirituality in those last years, which were characterized by great personal upheavals and illness.

${ }^{14}$ Helfenstein, "The Issue of Childhood in Klee's Late Work," 122-156; Franciscono, "Paul Klee and Children's Art," 112-117.

15 Osterwold, Paul Klee, 96, 123; Helfenstein, "The Issue of Childhood in Klee's Late Work," 122-156; Franciscono, "Paul Klee and Children's Art," 112-117; For a "timeline" of events in Klee's late years, see Roland Doschka, Paul Klee: Selected By Genius (London: Prestel, 2007), 213-214; See also Richard M. Silver, "Captive of Art, Not Disease: Paul Klee and his Illness, Scleroderma," The Pharos of Alpha Omega 71, no. 1 (2008): 16-24; Felix cites letters by Klee in the late years that indicate his distress in Paul Klee: His Life and Work in Documents, 190-191.

16 Doschka, Paul Klee: Selected By Genius, 213-214.

${ }^{17}$ Fineberg, The Innocent Eye, 114. 
Yet Klee also recognized the impossibility of his quest as early as 1918. In a diary entry, which was used on his gravestone in Bern, he writes:

I cannot be grasped in the here and now, for my dwelling place is as much among the dead, as the yet unborn, slightly closer to the heart of creation than usual, but still not close enough (see fig. 56). ${ }^{18}$

Klee's yearning for beginnings and the "heart of creation" - a source he sought through understanding children and studying their art - could no longer be realized in his lifetime. He had become estranged from a child's "inherent" knowledge of beginnings, children's unencumbered senses, and their ultimate understanding of a higher consciousness. After all his spiritual and metaphysical explorations into childhoodthrough fantasy, play, and unaffected, primordial senses - Klee died "still not close enough."

\section{The Continued Interest in Klee and Childhood}

Since his death, the association between Klee and childhood has continued unabated, not just in the scholarly literature, but in other more popular venues. In the remainder of the conclusion, I will address how this link continues to be forged through children's books and the Zentrum Paul Klee in Bern.

\section{Paul Klee and Children's Books}

In a 1905 letter to his future wife, Lily, Klee wrote that some of his works might find a welcome home in a child's book: "I continued to work on my children (...) I made a

18 Klee, The Diaries, "Recollections," 419. 
pair, which might do a children's book." ${ }^{19}$ Not only does Klee use children in this letter as a metaphor for his artistic practice, but this statement is also telling of Klee's recognition that some of his work would be suitable for a child to understand and appreciate. The precise works Klee refers to in the letter are unknown. However, judging from the correspondence date (November 2, 1905), it may be that Klee was referring to two untitled oil paintings he completed at that time (see figs. 57 and 58). Both works have qualities of a childlike aesthetic in the loosely rendered houses set in simplified landscapes.

Some of Klee's works have been incorporated into children's books since his death. At least ten children's books, to my knowledge, include Klee's work as illustrations; however, none of these books are fictional or fairy stories. ${ }^{20}$ Some of these include children's creative activity books where Klee's art is meant to engage with children's artistic processes in an unregulated manner. Many are educational books for childrenart-history works geared to youth that are common to artists like Picasso and Joan Miró.

One book that is particularly interesting, however, is Dreaming Pictures: Paul Klee (1998). ${ }^{21}$ In the work, Jürgen von Schemm published the responses to Klee's art by German school children from grade 4. The book is comprised of Klee's late work, such

${ }^{19}$ Paul Klee to Lily Stumpf, in Briefe an die Familie, 2 November, 1905, 533-534. ${ }^{20}$ Gillian Wolfe, Look! Drawing the Line in Art (London: Francis Lincoln, 2008); Paul Klee Colouring Book (New York: Prestel Publishing, 2008).

21 Some of these books include: Ernest Raboff, Kunst Für Kinder (Genf: Pappband, 1969); Jürgen von Schemm, Dreaming Pictures: Paul Klee (New York: Prestel Publishing USA, 1998); Christian Rumelin, Animal Tricks: Paul Klee (New York: Prestel Publishing, 2002); Sean Connolly, The Life and Work of Paul Klee (Oxford: Heinemann First Library, 2006); Birgit Brandenburg, Paul Klee für Kinder: Eine Werkstatt (Verlag: Verlag An der Ruhr, 2002); Sean Connolly, Take-Off! The Life and Work of Paul Klee (Oxford: Heinemann Library Hardbacks, 2002); and Raboff, E., Art for Children: Paul Klee (New York: Harper Collins, 1988). 
as A Children's Game (1939) (fig. 59), and the children's questions, insights, and suggestions, which float around on the opposite page. Recording the responses of children to Klee's work is interesting in that it employs a similar method that HansFriedrich Geist used in $1930 .^{22}$ Most of the works that Geist included in his article were from the 1920s, such as Klee's well-known Angelus Novus (1920). ${ }^{23}$ While Geist includes the children's comments in a journal article, Schemm presents them in a book for other children to see and reflect upon.

Moreover, over sixty of Klee's drawings have been used to illustrate a 1949 edition of The Novices of Saïs (1802) by the writer and philosopher Novalis. ${ }^{24}$ In this fairy tale, Novalis praises children and a childlike vision. Klee's appearance in The Novices and the children's books mentioned above reveals that Klee continues to be associated with childhood, children's education and creativity, and fantasy in popular culture.

\section{Kindermuseum Creaviva at the Zentrum Paul Klee}

The Zentrum Paul Klee also continues to foster interest in Klee and childhood. This center, a newly established gallery (2005), research, and cultural gathering place situated in Klee's native Bern, Switzerland, houses much of the artist's work and writings (fig. 60). Designed by the Italian architect Renzo Piano, the center itself blends in with the Bernese landscape of curving hillsides and the Swiss Alps. Piano envisioned the center as "a spacious island of green from which the architecture would

22 Geist, "Kinder über Paul Klee," 21-26.

23 Geist, "Kinder über Paul Klee," 23-24.

${ }^{24}$ Novalis, The Novices of Saïs, trans. Ralph Manheim (Brooklyn, N.Y: Archipelago Books, 2005): see 27-29, 117-119; For a discussion of the fairy-tale aspects of the story, see Donald Hasse ed., The Greenwood Encyclopedia of Folktales and Fairy tales, vol. 2 (Westport, CT: Greenwood Press, 2008), 690. 
emerge in the form of three undulating waves." ${ }^{25}$ In this way, the Zentrum is contoured both to mimic the vast surrounding landscape and to add interest to the hillsides, relating the architecture directly to Klee's artistic ideal of making the invisible visible. ${ }^{26}$

The Kindermuseum Creaviva, which occupies almost the entire first floor, is dedicated to the interaction of children and their artistic sensibilities (fig. 61). The school's mandate is to offer a wide range of interactive and creative activities that engage children with the art of Klee. They also encourage Klee's creative teachings: to create with the senses in mind and experiment imaginatively with lines, colours and textures. Children from the age of four can join classes and play with their creative expression through a variety of crafts, methods and materials. Children also play in the center with their own figurative creations like puppets.

Similar to how Geist and Schemm give value to children's responses to the work of Klee, the Kindermuseum Creaviva encourages children to think about and connect with Klee's work (fig. 62). Not only do children discuss his art, they also mimic some of his pictorial themes and imagery in their own work. For example, Klee's Ad Parnassum (1932) (fig. 63) is reinterpreted through a young child's imagination (fig. 64). Indeed the child's similar rendering of a mountain with a sun and clouds is formally reminiscent of Klee's polyphonic style of the late twenties and early thirties that explored his theories of colour, light and movement. ${ }^{27}$

${ }^{25}$ See the Zentrum Paul Klee website, http://www.zpk.org/ww/en/pub/web_root/zpk.cfm. ${ }^{26}$ Michael Weinstock, "Can Architectural Design be Research?" Architectural Design 78, no. 4 (July, 2008): 126-129.

${ }^{27}$ Paul Klee's work of the early thirties is characterized by an interest in colour, movement, and solving the problem of light by means of polyphony. See Geelhaar, Paul Klee and the Bauhaus, 140. 
As we have seen, not only did Klee appreciate children's play, but he also valued the uncultivated expression found in children's art - especially their pictures that do not attempt to mimic another's but remain free, natural, and imaginative. At the gallery, children are also encouraged to find their own voice through the playful method of finger painting, an elementary process that, as discussed above, Klee used and connected to childhood.

The Kindermuseum Creaviva also possesses an extensive collection of over 1000 German schoolchildren's drawings from the 1950's and 1960's, donated by the St. Gallen educationalist, Hans Hochreuter. ${ }^{28}$ This collection is accessible to the Kindermuseum's educational staff, and is occasionally exhibited in the center along with contemporary children's art. Some of the works are profoundly creative and insightful, such as one picture by a child from 1951 with the title "The Angel Appears to the Shepherd on a Field" (fig. 65). In the work, a large, horizontally angled head emerges to some sleeping shepherds in a field. Presumably the looming angel is preaching to the men of the coming of Christ. Many of the works in the collection resemble Klee's art, indicating that children from German schools in the 1950's and 1960's were indeed directly engaging with Klee's work for inspiration in the context of the classroom. For example, one child's picture from 1950 seems directly inspired by Klee's work of the early 1930's - his polyphonic compositions - such as Colour Table (In Grey Major) (see fig. 66 and 67). ${ }^{29}$ This celebration of children's art in the context

28 This information is taken from the Kindermuseum Creaviva's website,www.creavivazpk.org/en/join-us/schools/collection-hochreutener (accessed April 13, 2010).

29 See Waldemar Januszczak, Techniques of the Great Masters of Art (Secaucus, N.J:

Chartwell Books, 1985). 
of the Zentrum Paul Klee acknowledges the artist's attempt to overhaul traditional art practice through a return to children's sensibilities and artistic devices.

While most museums are not child-friendly places, the Zentrum Paul Klee accommodates children in their gallery space and acknowledges Klee's interest in childhood - an affinity for which he sustained great criticism during his lifetime. In 2009-2010, the Zentrum held the exhibition "Paul Klee. Life, Work and Responses," which also celebrated Klee's connection to childhood. ${ }^{30}$ On display were Klee's childhood pictures, which were juxtaposed to some of his later work, and the show also included some of Felix's early pictures that Klee may have also used for inspiration. Klee's diary, opened to a page from his "Memories from Childhood," and his puppets, were also included in the show. Klee would have particularly valued the center's departure from the traditional gallery role as one that both acknowledges his interest in childhood and nurtures the art of children within its space. Klee after all stated that "children have artistic ability too." ${ }^{31}$ The Zentrum Paul Klee's fostering of their art provides creative empowerment to children in a gallery space and, in effect, ascribes special value to children's creative potential, as Klee did.

30 The exhibition was on display at the Zentrum Paul Klee from September 19, 2009May 24, 2010. See the website for more details, www.paulkleezentrum .ch /ww/en/ pub/web_root/pro/wechselausstellungen/paul_klee__leben_und_nachlebe.cfm.

31 Klee, Schriften, Rezensionen und Aufsätze, 97. 


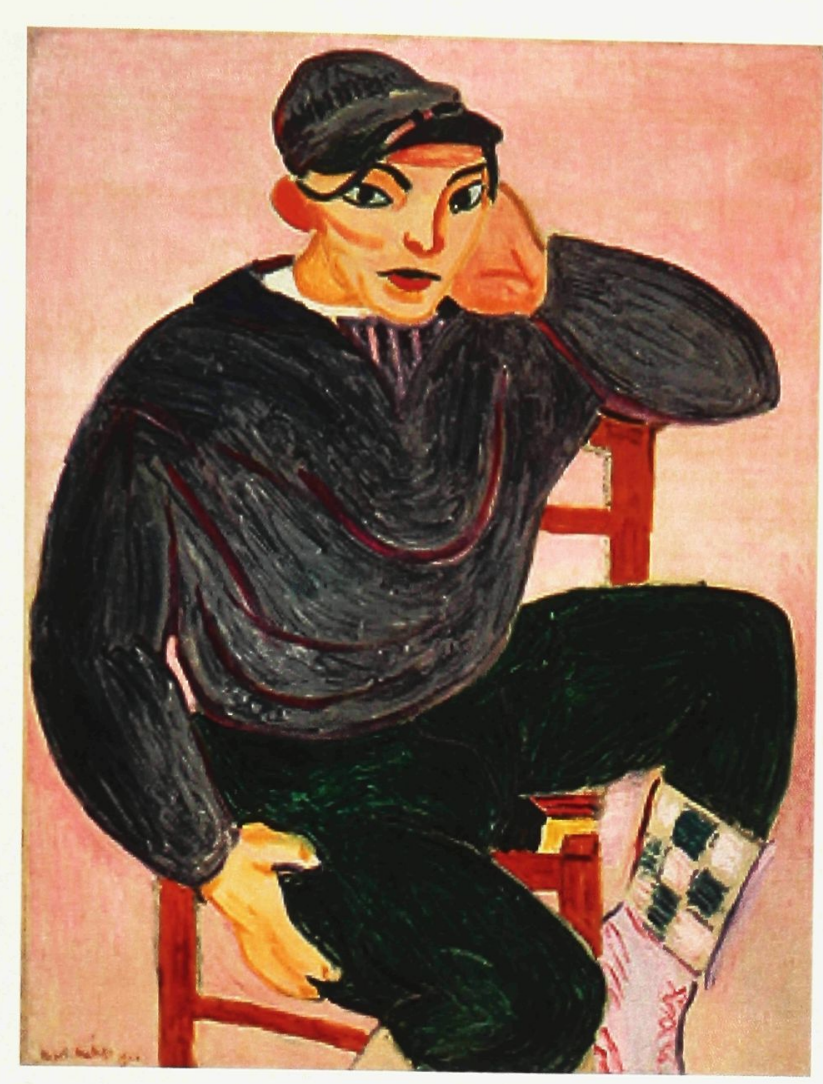

Figure 1

Henri Matisse

The Young Sailor (II), Collioure, summer 1906

Oil on canvas

$40 \times 323 / 4$ in. $(101.5 \times 83 \mathrm{~cm})$

Metropolitan Museum of Art, New York, The

Jacques \& Natasha Gelman Collection 


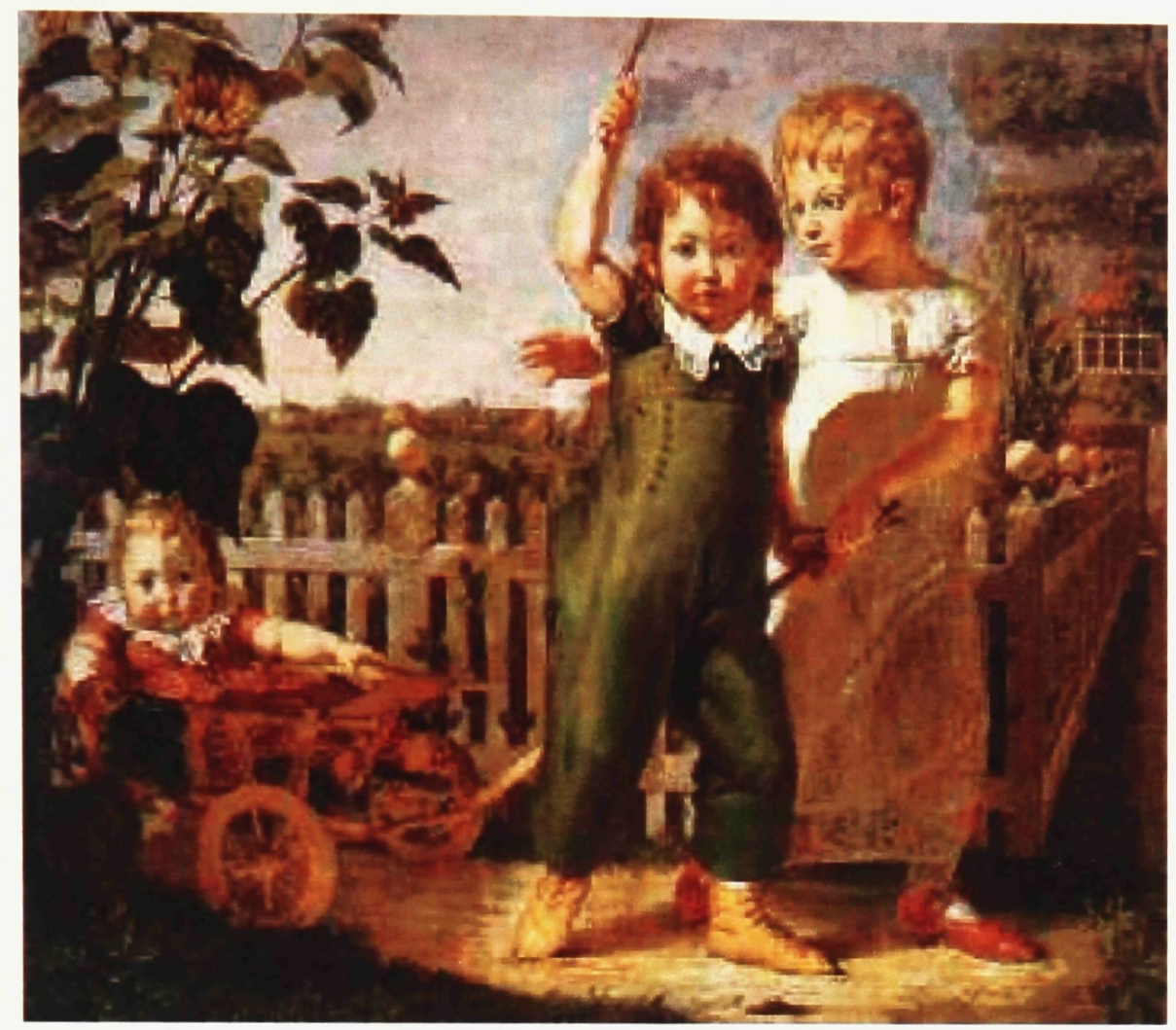

Figure 2

Philipp Otto Runge

Hülsenbeck Children, 1805-6

Oil on canvas

$131.5 \times 143.5 \mathrm{~cm}$

Hamburger Kunsthalle 


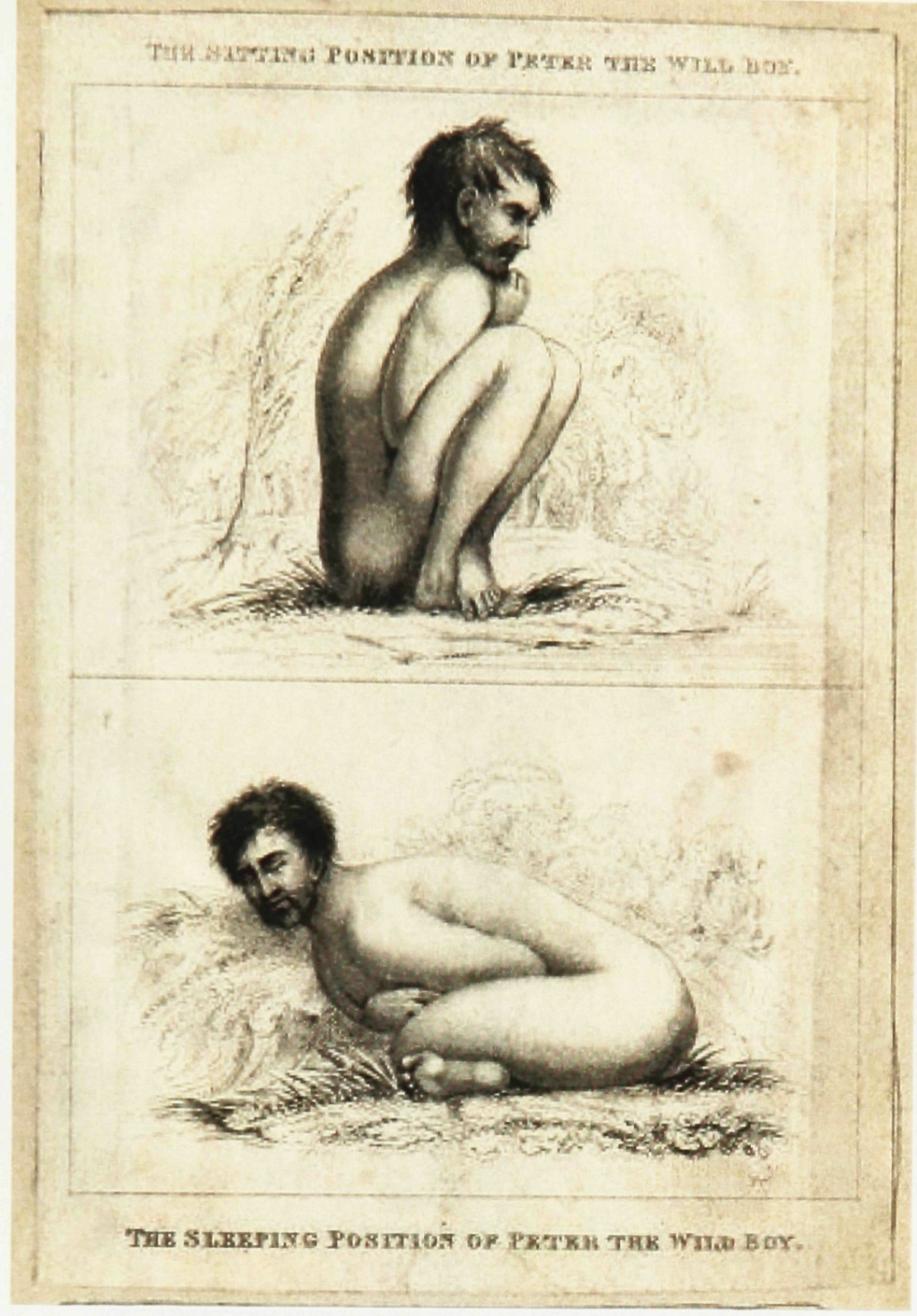

Figure 3

Unknown artist

Peter the Wild Boy, early $19^{\text {th }}$ century

Stipple engraving

$19.4 \times 13.4 \mathrm{~cm}$

National Portrait Gallery of London 


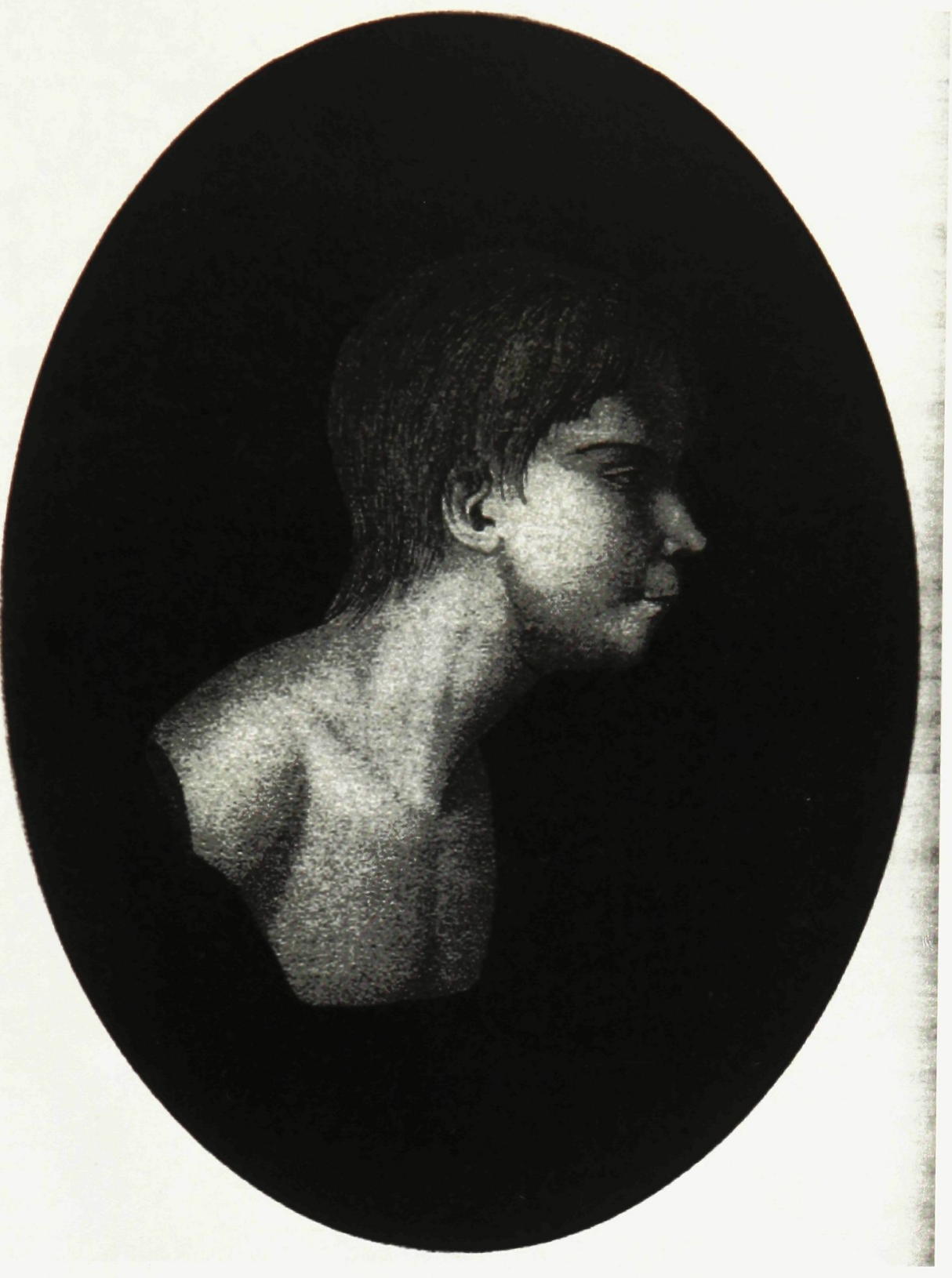

Figure 4

Unknown artist

Portrait of Victor, c. early $17^{\text {th }}$ century

Frontispiece of Jean Itard's De l'Êducation d'un homme sauvage, ou des premiers développemens physiques et moraux du jeune sauvage de l'Aveyron Paris, 1801 


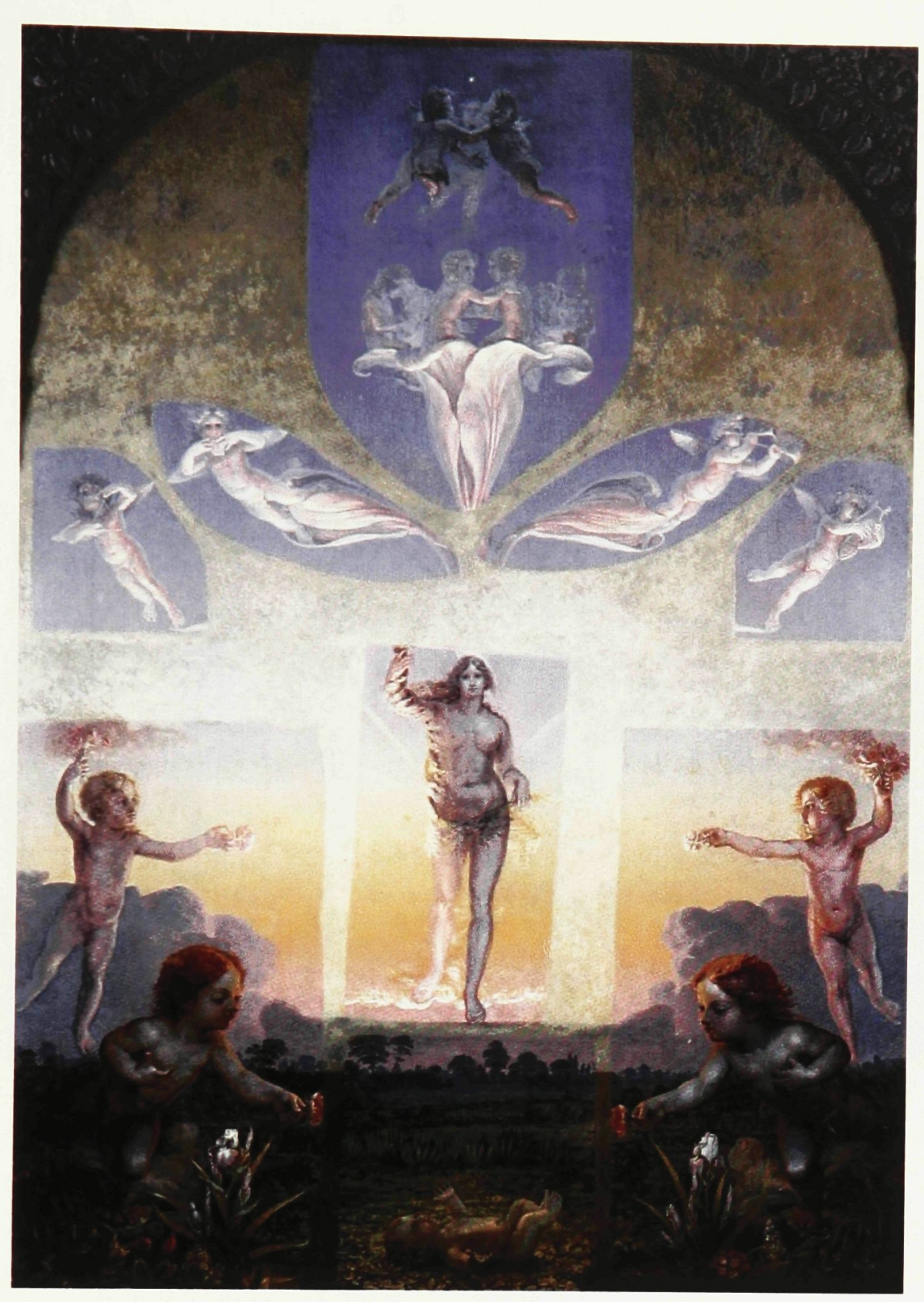

Figure 5

Philipp Otto Runge

The Great Morning 1809-10

Oil on canvas

$152 \times 113 \mathrm{~cm}$

Hamburger Kunsthalle 


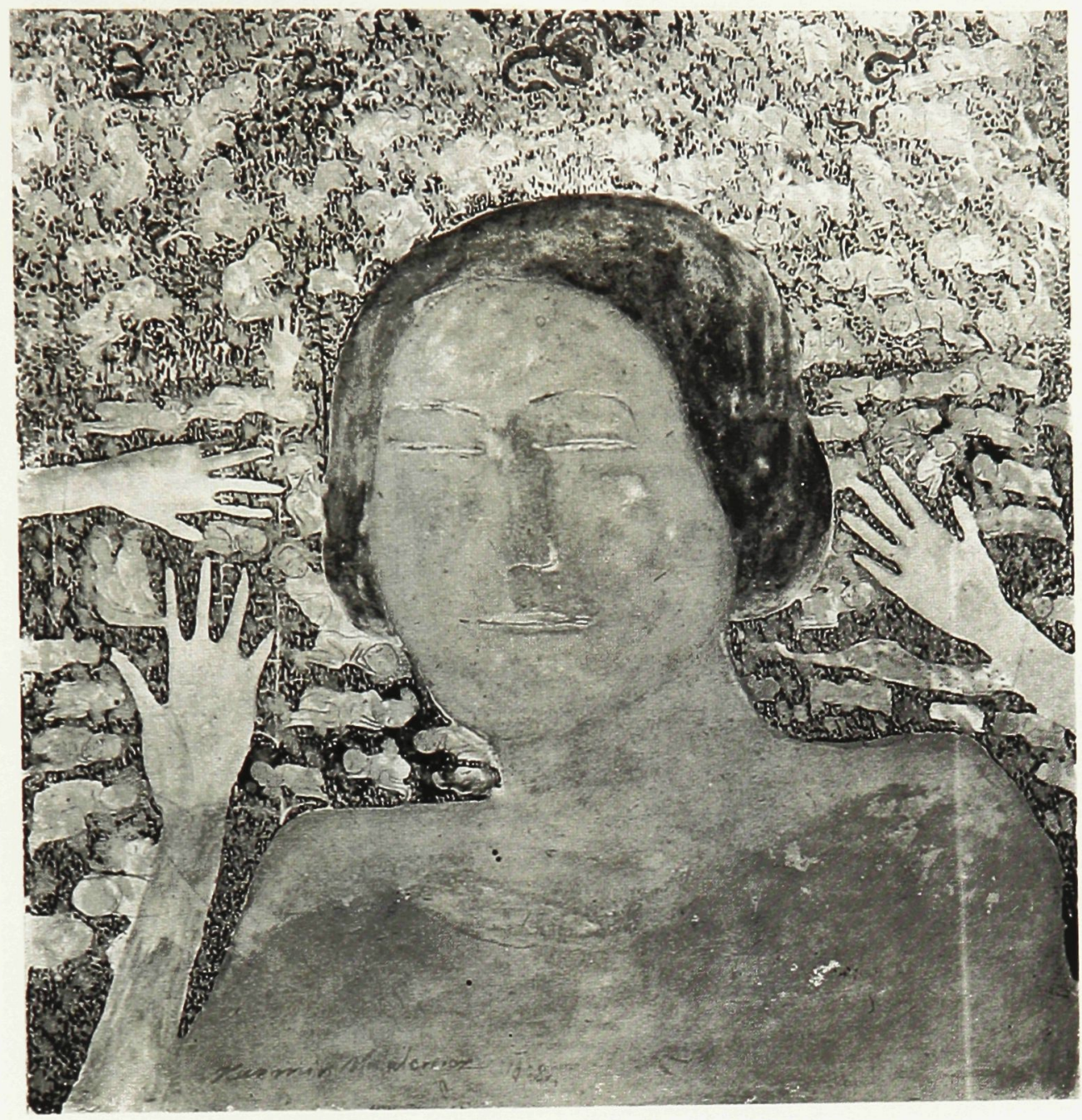

Figure 6

Kazimir Malevich

Woman in Childbirth, 1908

Oil and pencil on board

$24.7 \times 25.6 \mathrm{~cm}$

The George Costakis Collection 


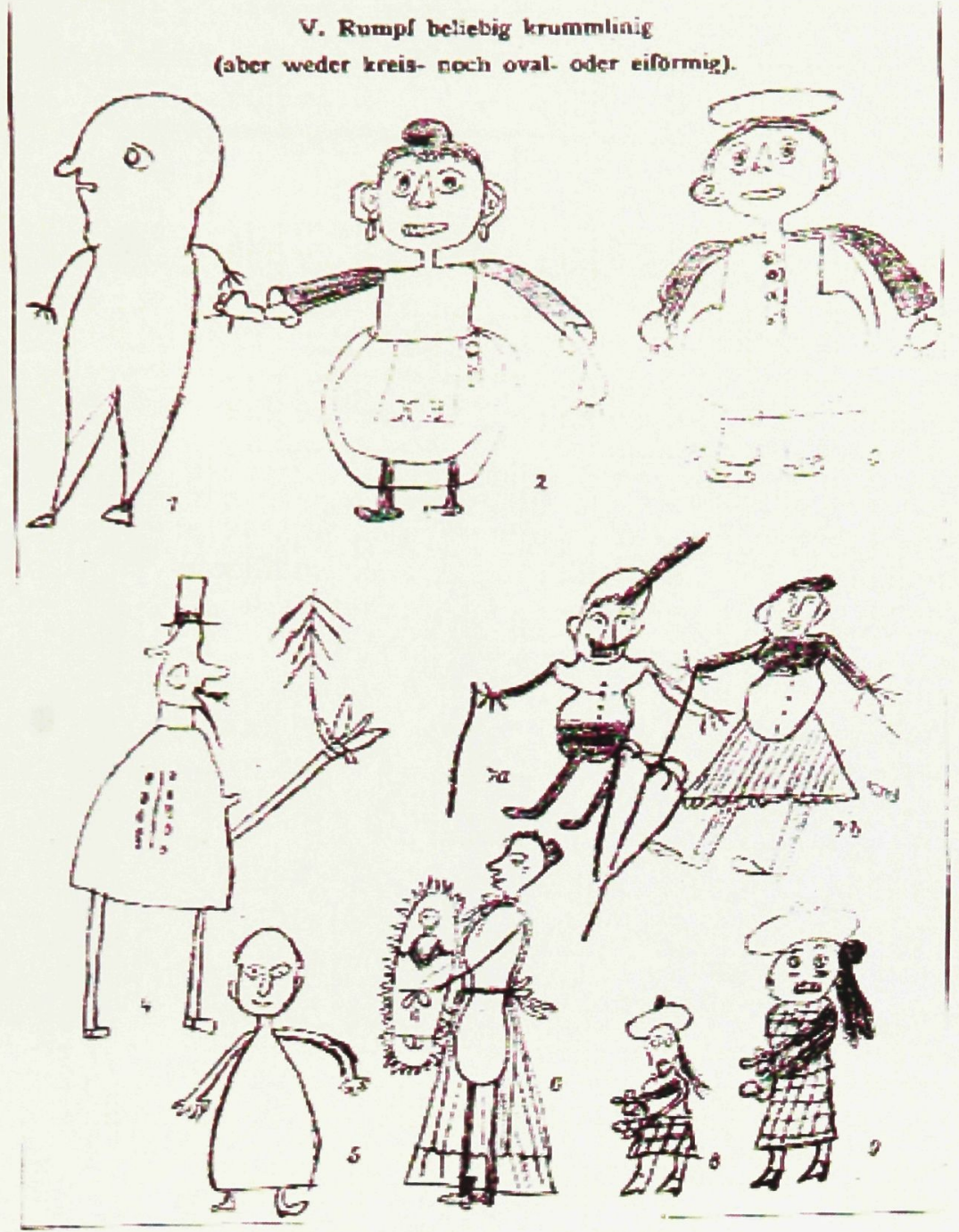

Figure 7

Child's drawing

Plate 10, from Georg Kerschensteiner,

Die Entwicklung der zeichnerischen Begabung

(The Development of the Gift of Drawing)

Munich, 1905 


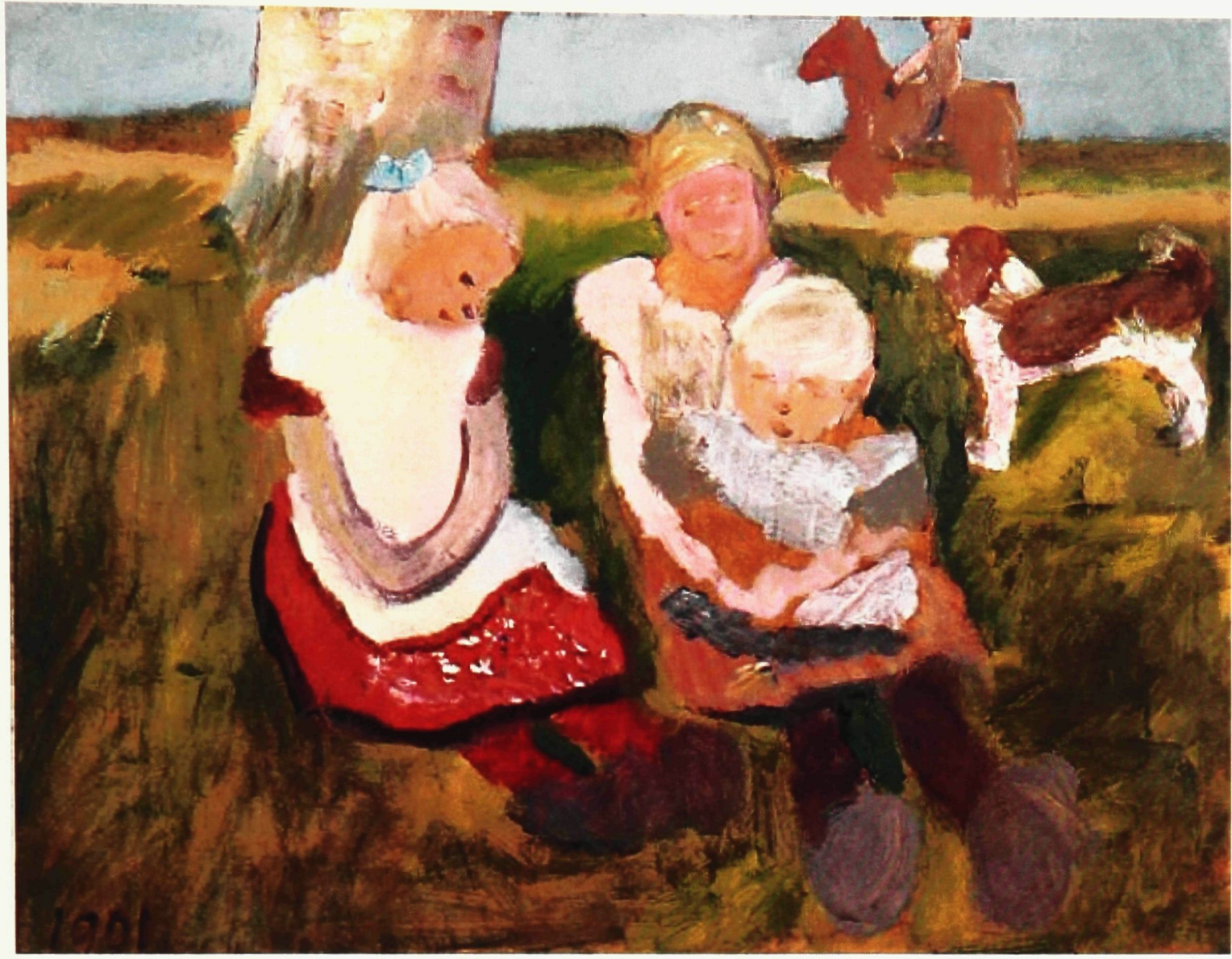

Figure 8

Paula Modersohn-Becker

Drei Kinder an einem Hang sitzend mit Hund und Pferd, 1901

Oil on cardboard mounted on wood

Galerie Ludorff, Düsseldorf 


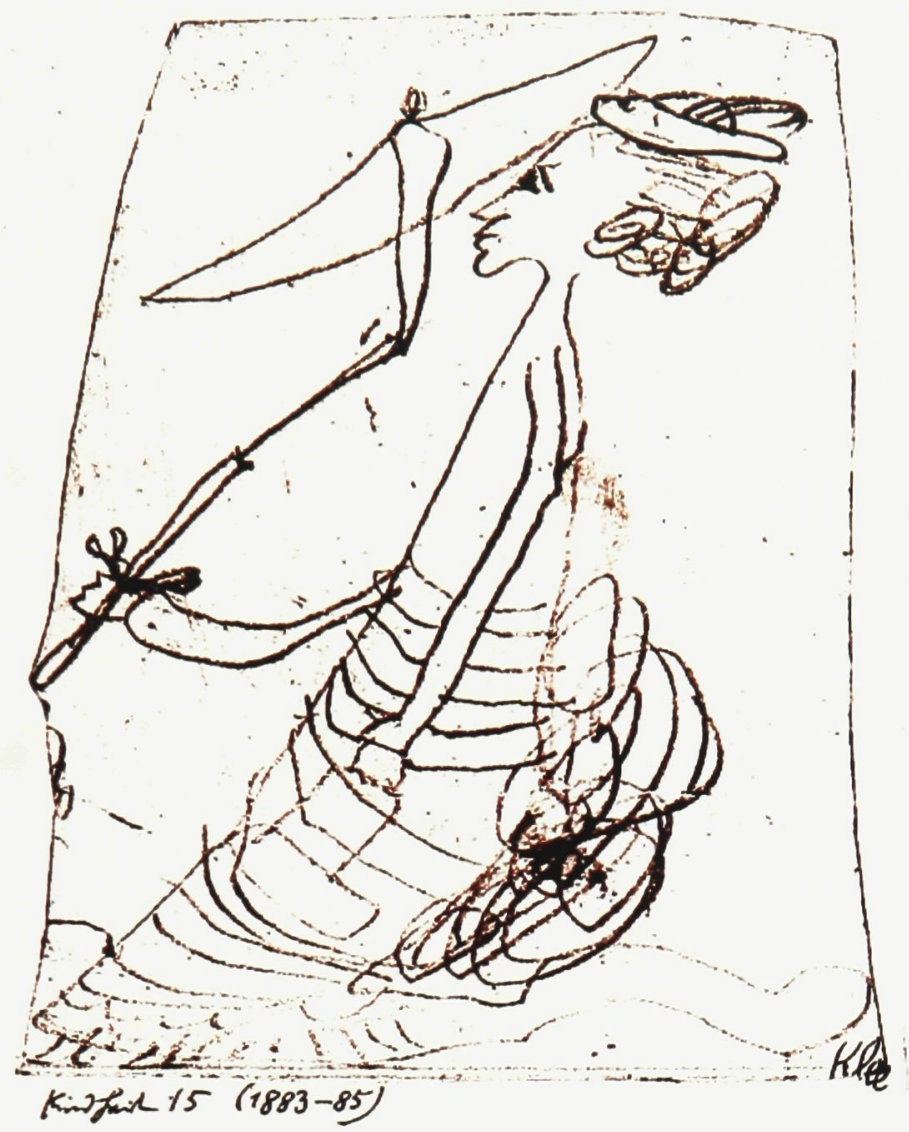

Figure 9

Lady with Parasol, c. 1883-1885

Pencil on paper

$43 / 8 \times 31 / 4$ in. $(11.2 \times 8.2 \mathrm{~cm})$

Paul Klee-Stiftung, The Zentrum Paul Klee 


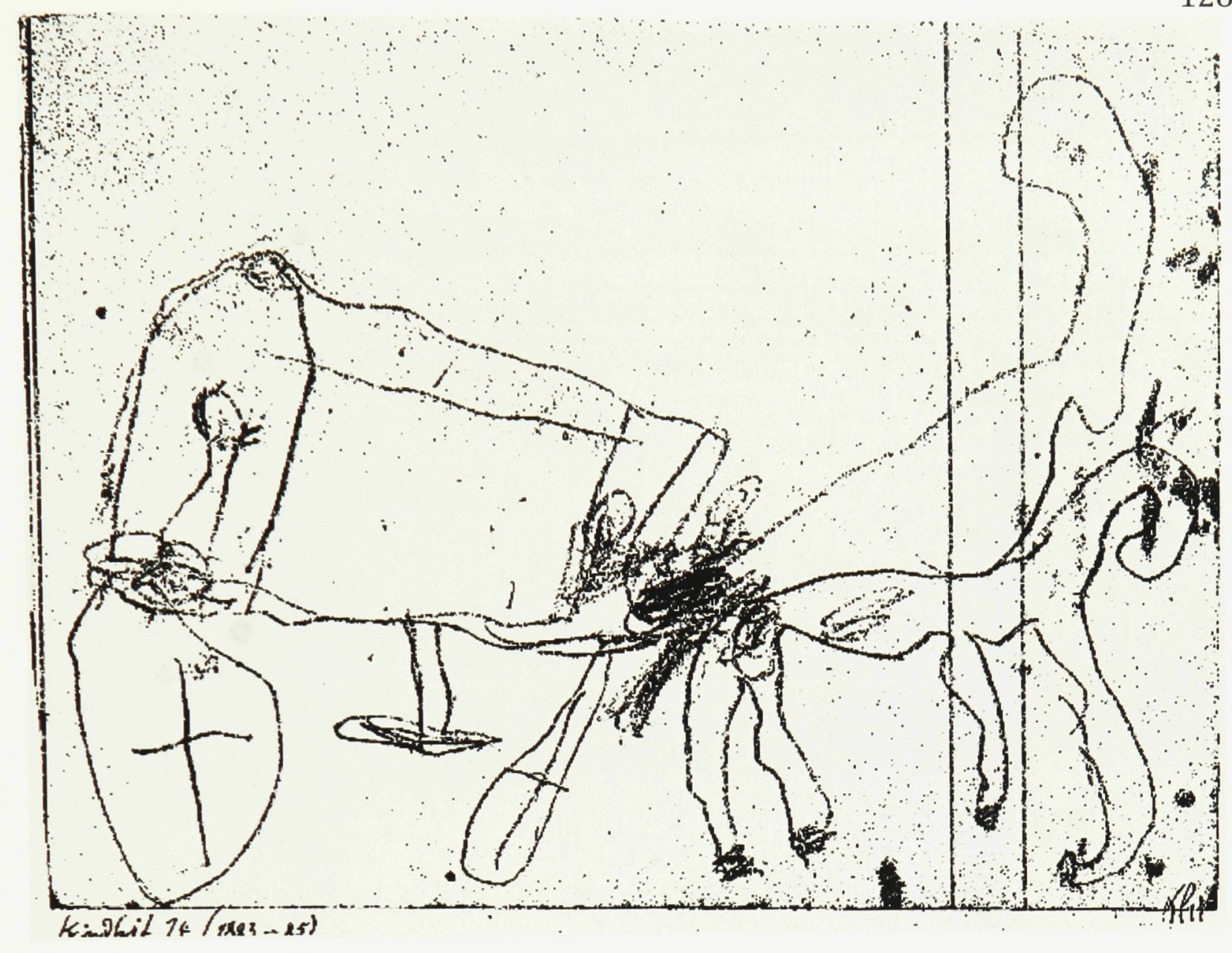

Figure 10

Horsedrawn Carriage, c. 1883-1885

Pencil and coloured crayon

$41 / 8 \times 53 / 4$ in. $(10.6 \times 14.7 \mathrm{~cm})$

Private collection, Bern 


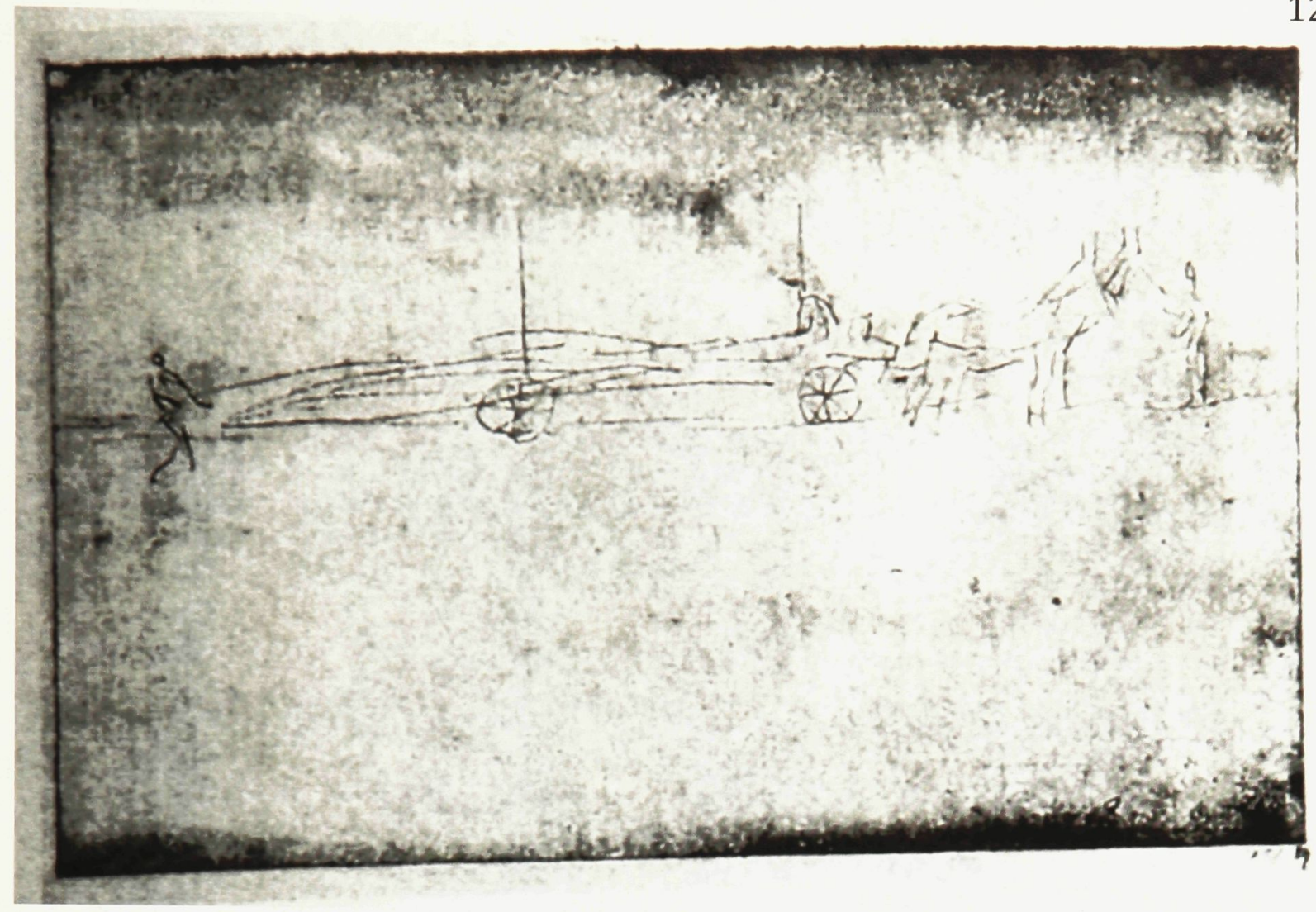

Figure 11

A Cart with Two Horses, Just Before Departure, 1908 Ink and watercolour on paper on cardboard $11.3 \times 17.8 \mathrm{~cm}$

Galerie Rosengart, Luzern 


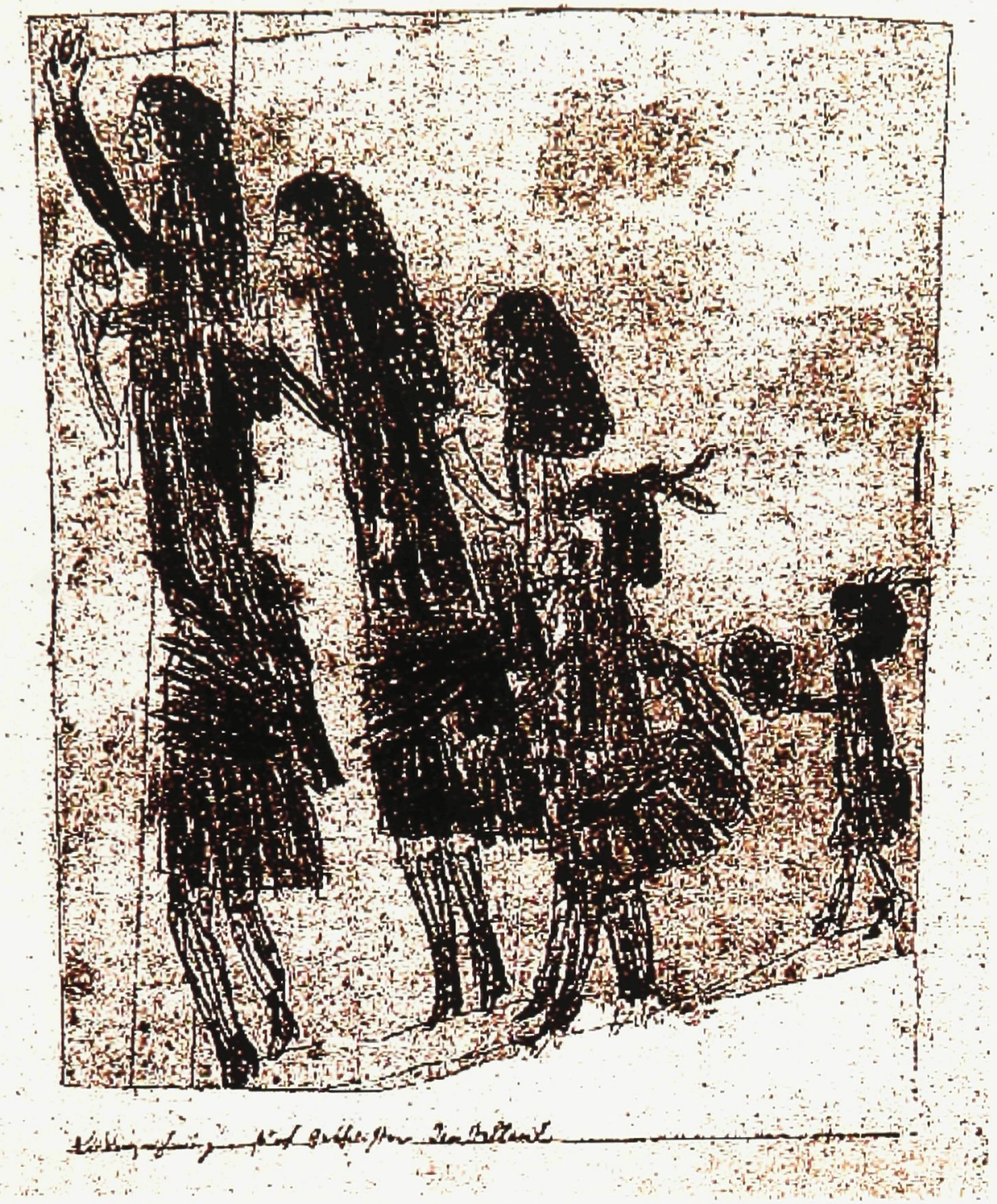

Figure 12

Child's Drawing, Portraying Five Sisters, c. 1885-1889

Coloured pencil on paper on cardboard

$18.3 / 16$ x 14/13.3 cm

Private Swiss Collection 


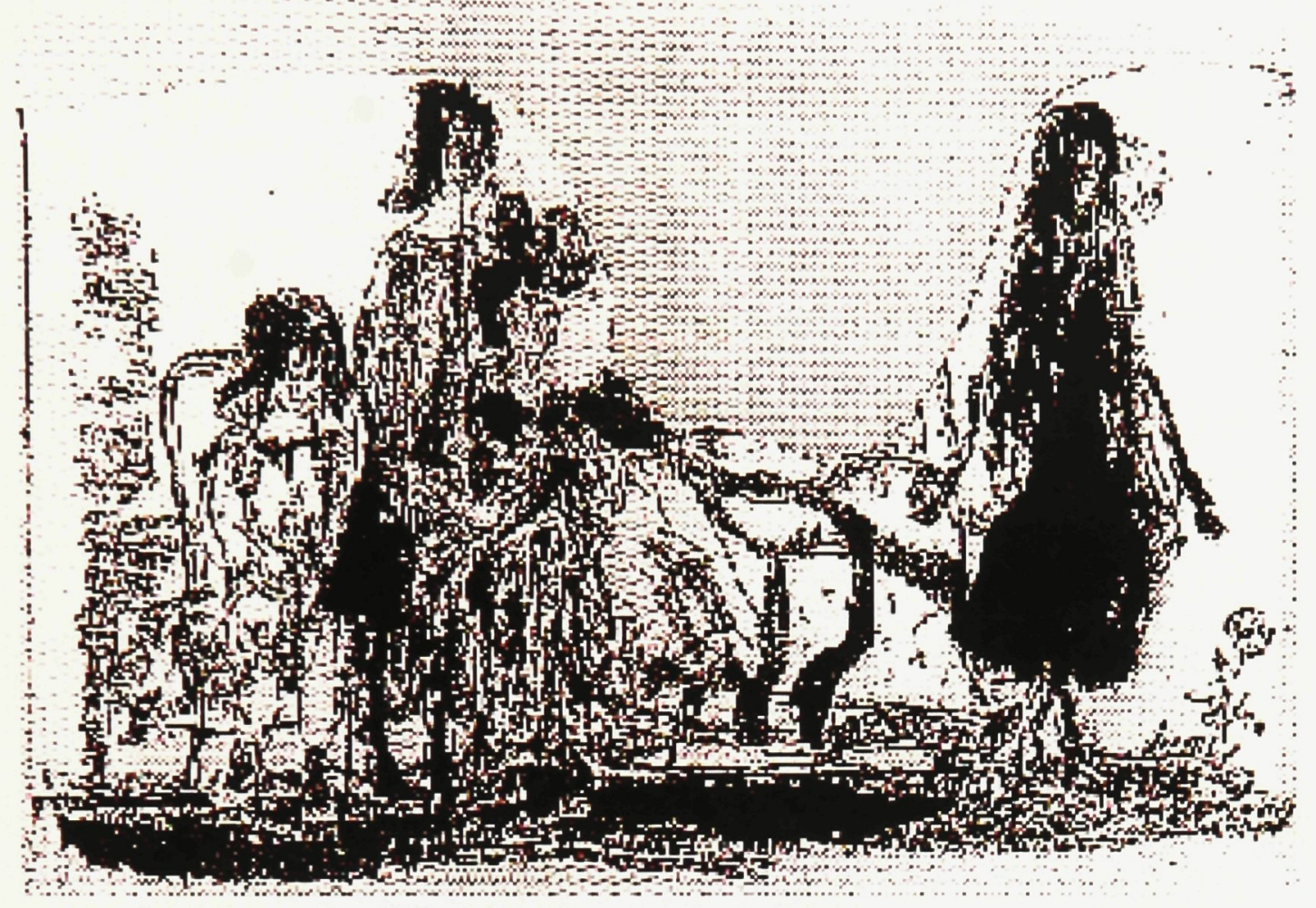

Figure 13

A Sick Girl Being Visited by Some Girlfriends, Five Figures, 1909 Ink on paper on cardboard

$16.9 \times 31.5 \mathrm{~cm}$

Paul Klee-Stiftung, The Zentrum Paul Klee 


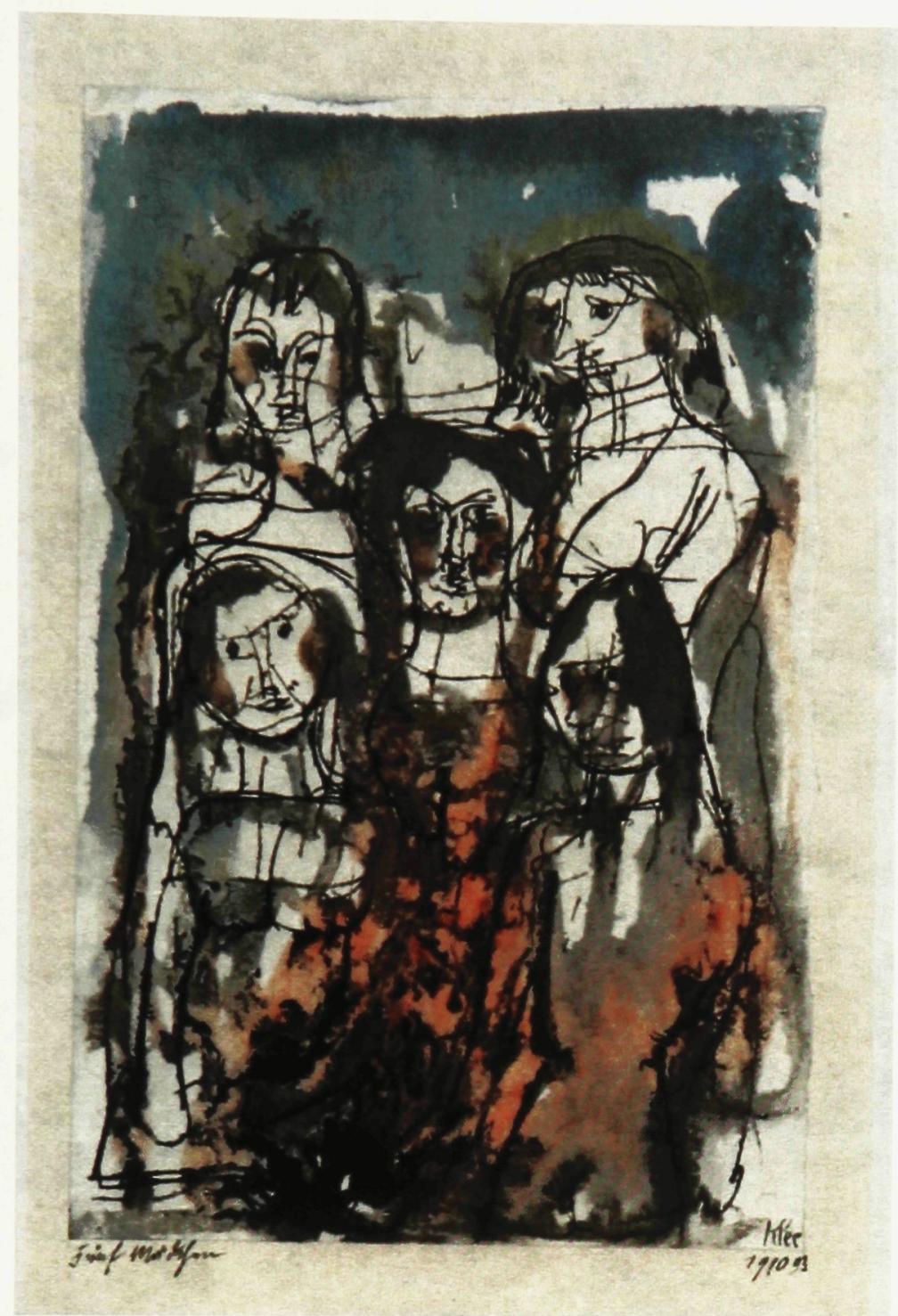

Figure 14

Five Girls, 1910

India ink and watercolour on paper on cardboard $17.8 \times 11.5 \mathrm{~cm}$

Kunsthaus Zürich 


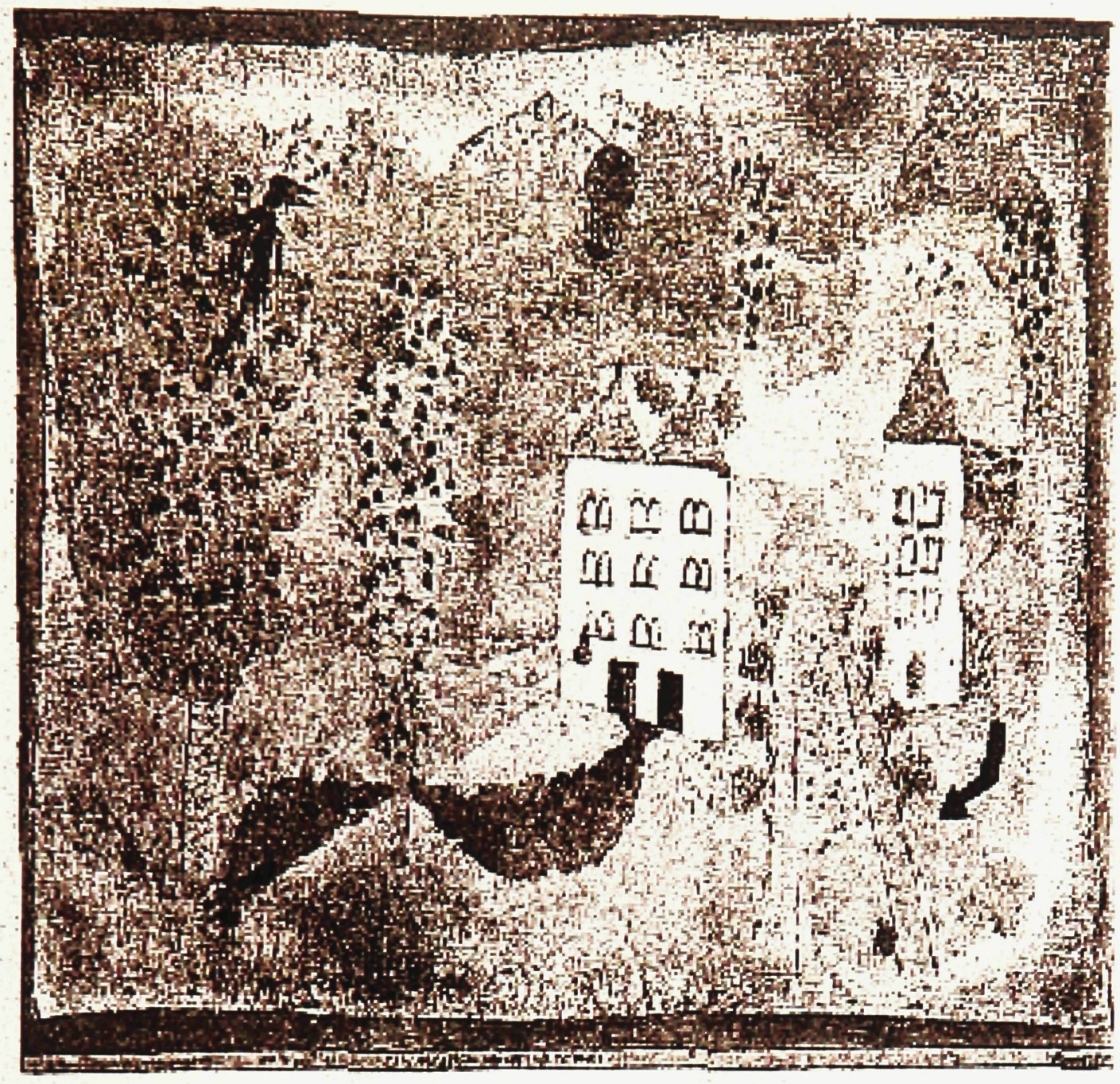

Figure 15

Scene of a Drama, 1923

Watercolour and plaster on nettle cloth, above and below edge strip with watercolour and ink, on cardboard

$31 \times 47 \mathrm{~cm}$

Location unknown 


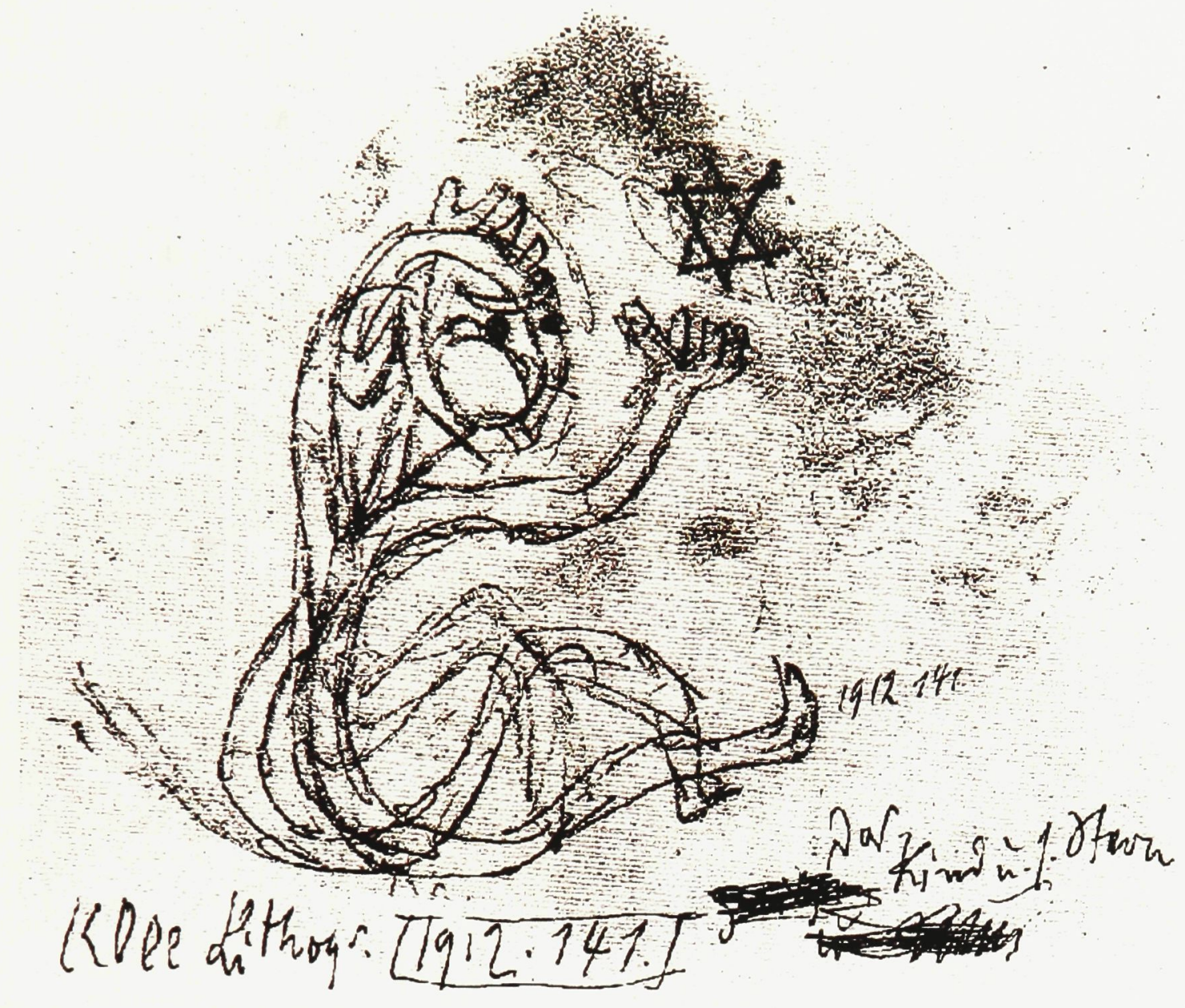

Figure 16

Child and the Star, 1912

Pencil on paper

$8.2 \times 10 \mathrm{~cm}$

Private collection, Switzerland 


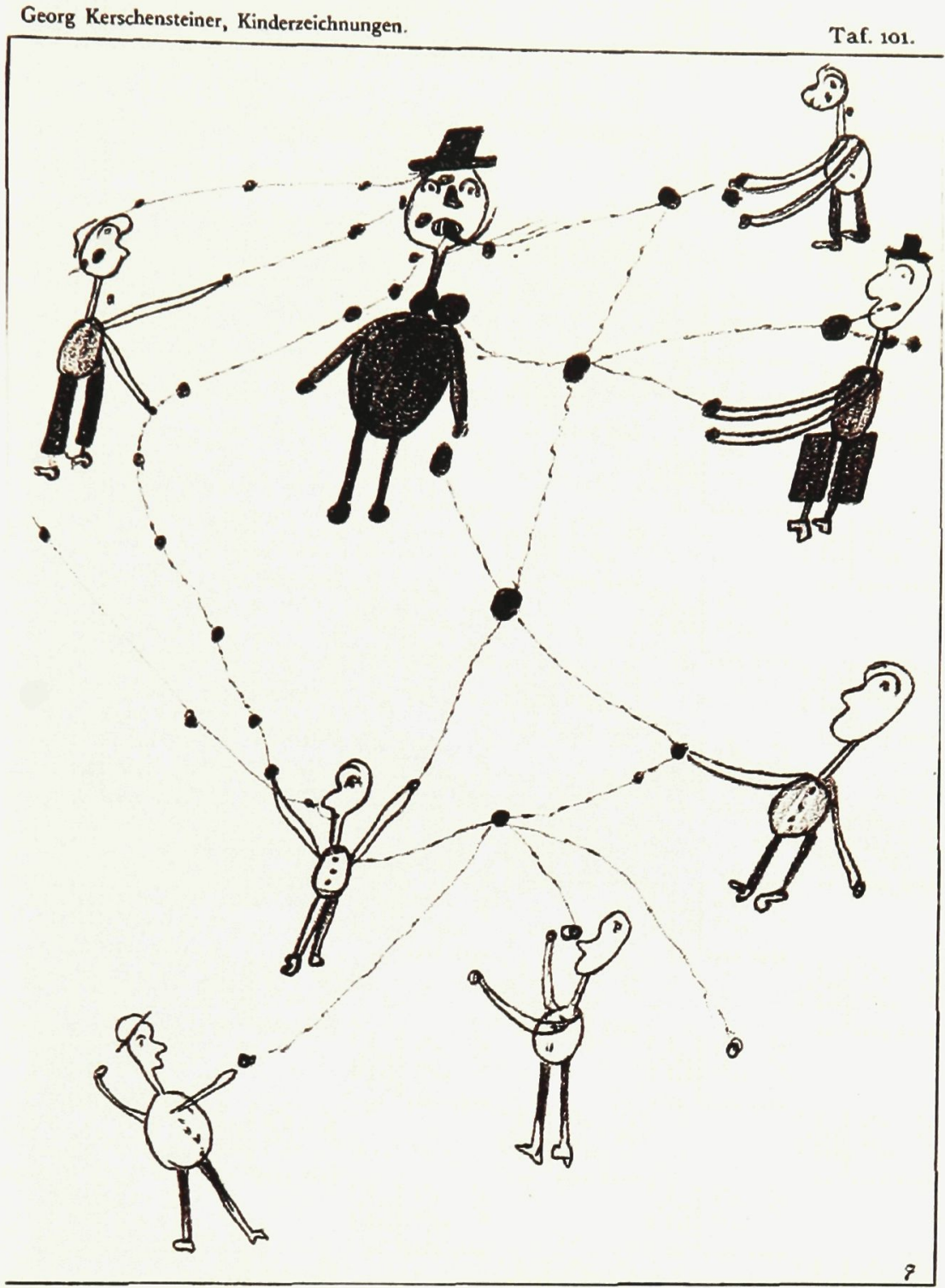

Darstellung eines Schneeballgefechts. Faksimile nach dem Original.

Figure 17

Child's drawing

Plate 101, from Georg Kerschensteiner,

Die Entwicklung der zeichnerischen Begabung

(The Development of the Gift of Drawing)

Munich, 1905 


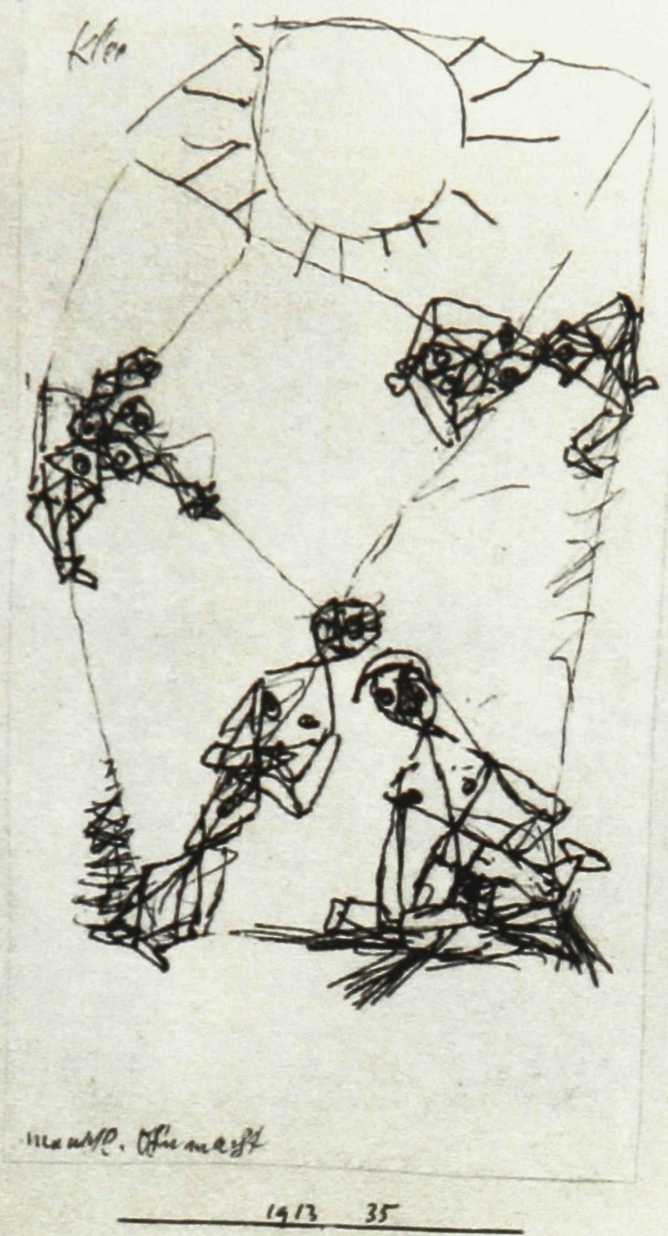

Figure 18

Paul Klee

Human Helplessness, 1913

Tusche on paper

$8.2 \times 10 \mathrm{~cm}$

Paul Klee-Stiftung, The Zentrum Paul Klee 


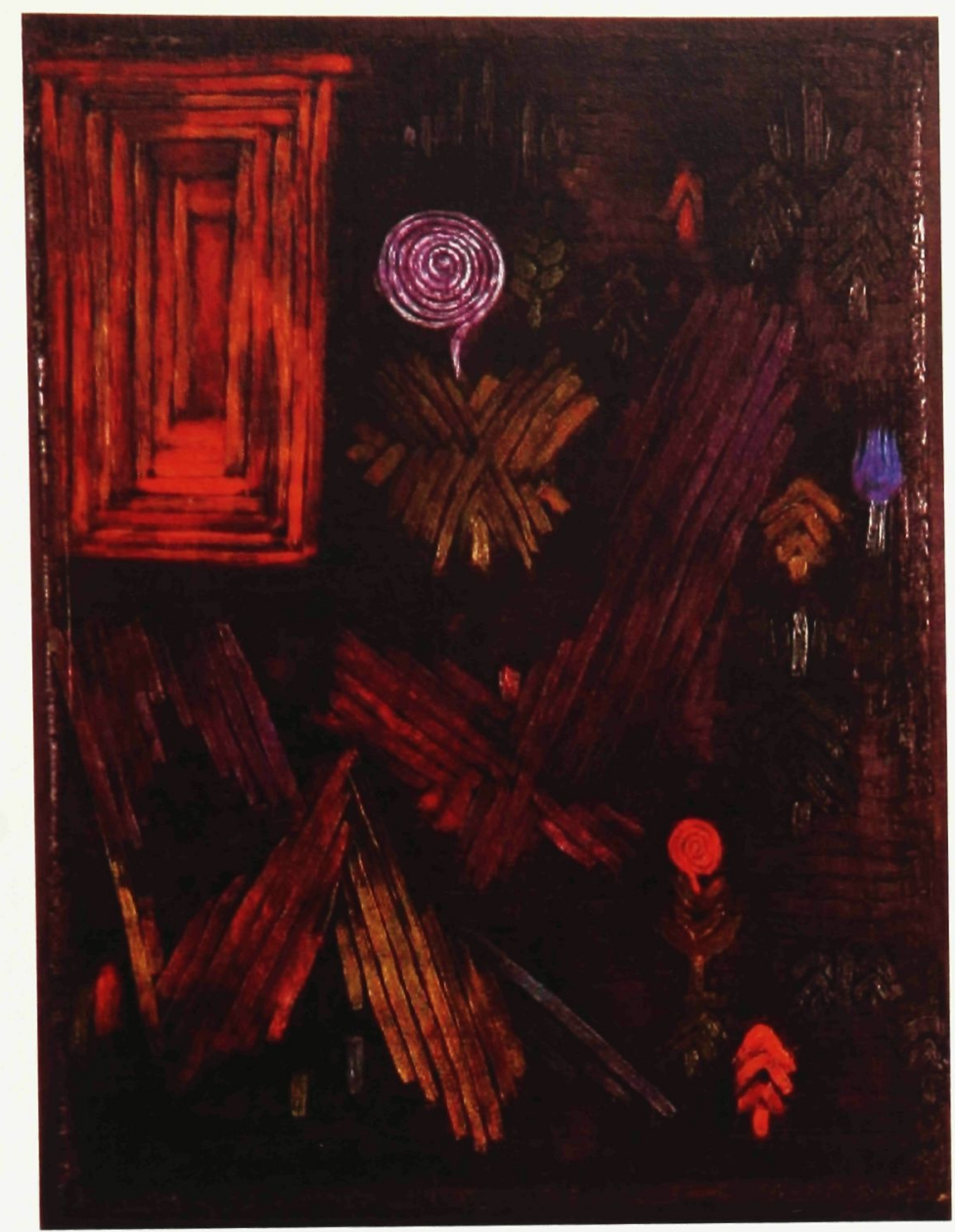

Figure 19

Gate in the Garden, 1926

Oil on cardboard

$54.5 \times 44 \mathrm{~cm}$

Paul Klee-Stiftung, The Zentrum Paul Klee 


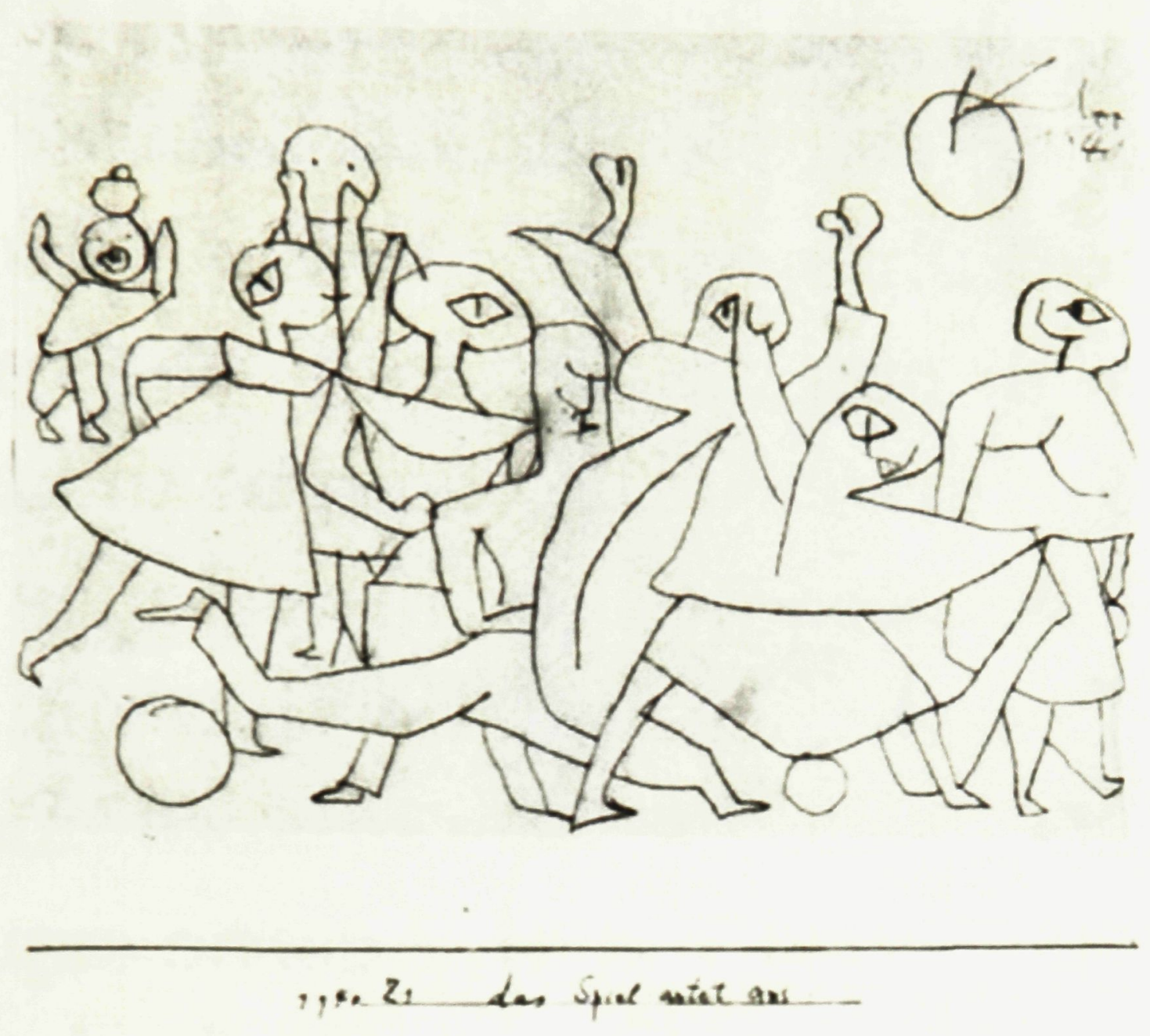

Figure 20

Paul Klee

The Game Degenerates, 1940

Pencil on paper

$20.9 \times 29.6 \mathrm{~cm}$

Paul Klee-Stiftung, The Zentrum Paul Klee 


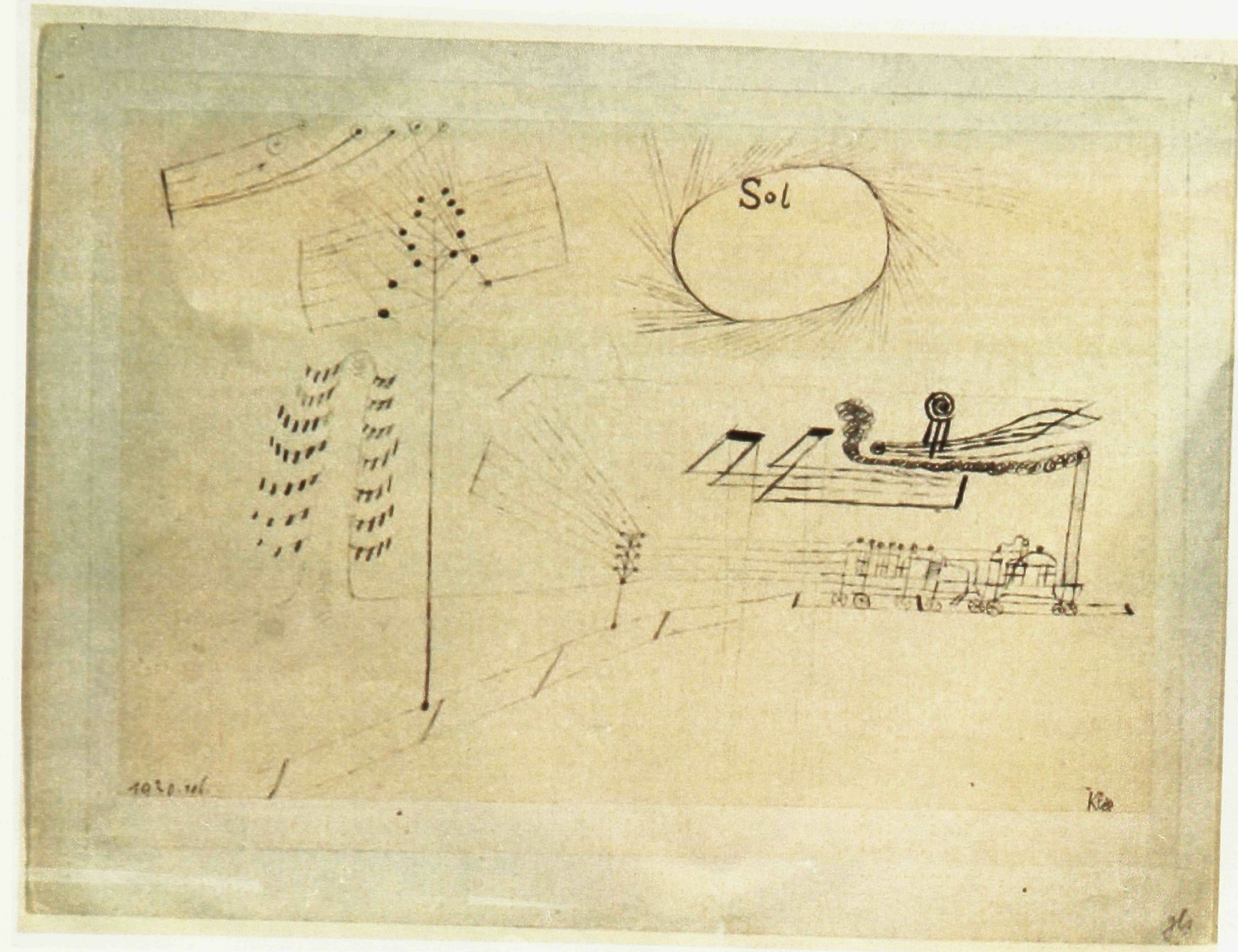

Figure 21

Paul Klee

Sol, 1920

Ink on paper

$18.6 \times 28.3 \mathrm{~cm}$

The National Gallery of Canada 
B. Darstrllung im Aufris.

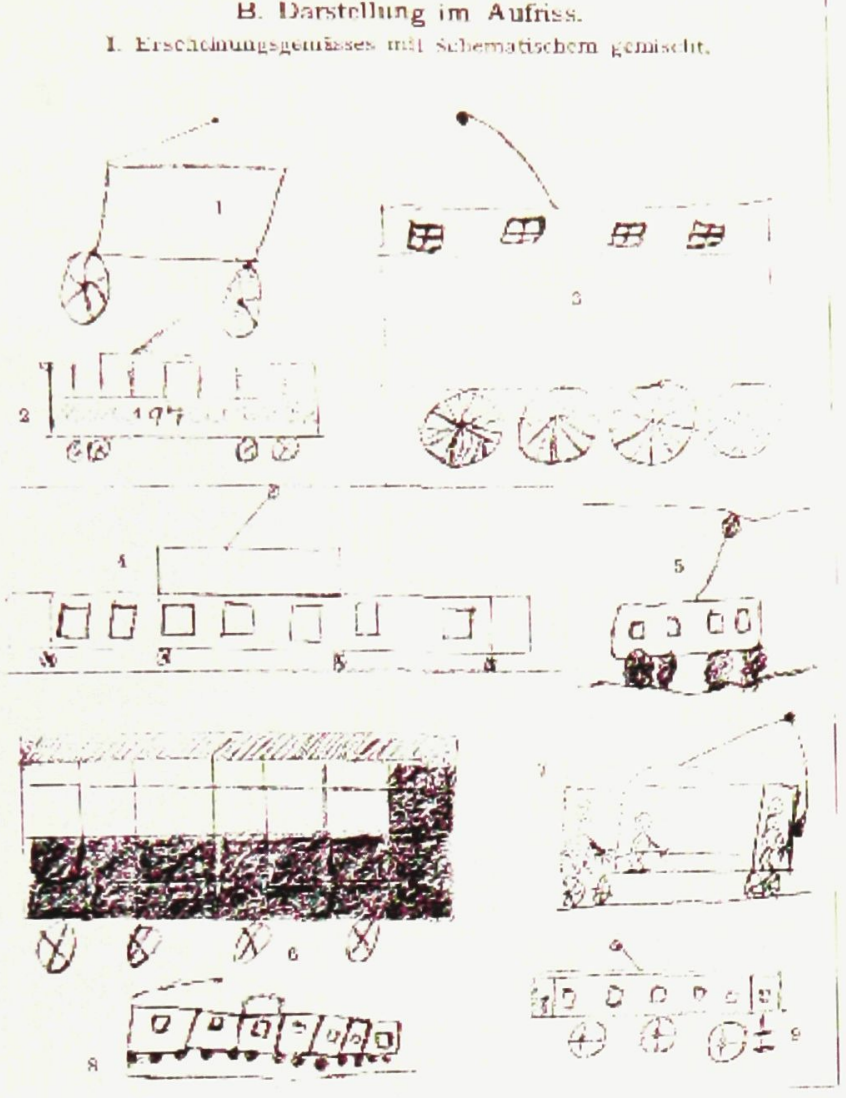

Figure 22

Child's drawing

Plate 60, from Georg Kerschensteiner,

Die Entwicklung der zeichnerischen Begabung

(The Development of the Gift of Drawing)

Munich, 1905 
A. Reines Schema.

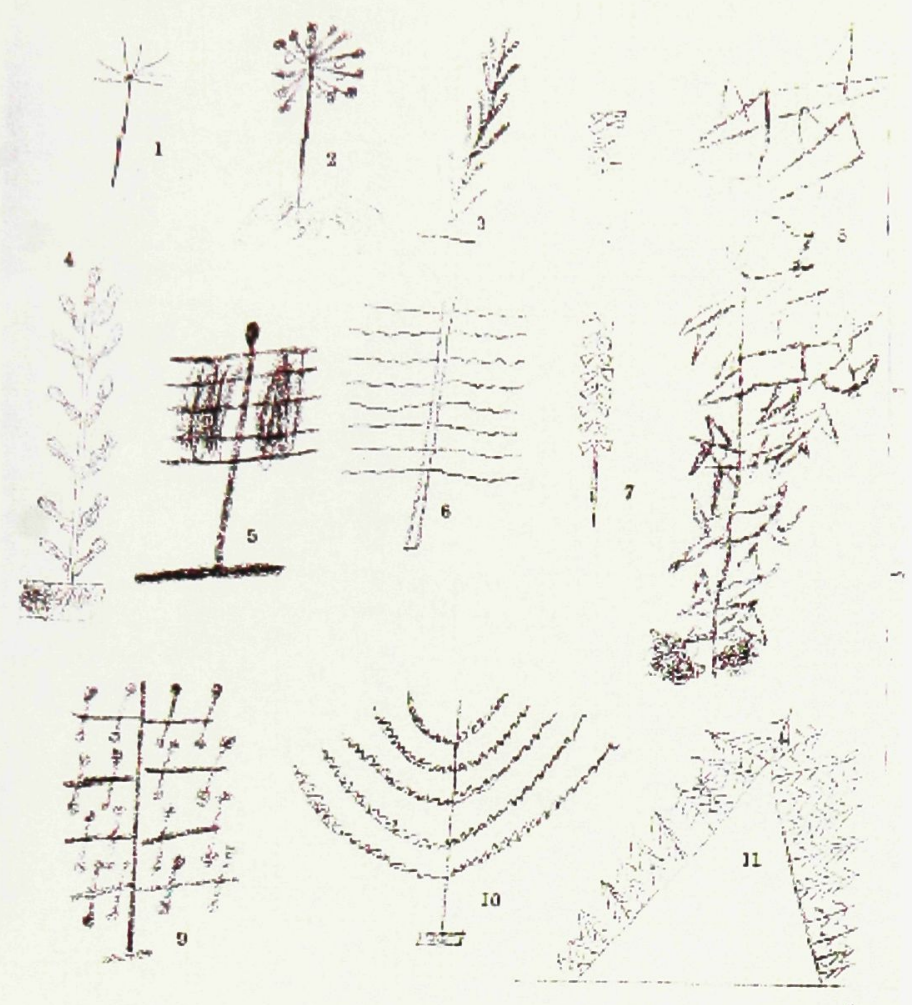

Figure 23

Child's drawing

Plate 76, from Georg Kerschensteiner, Die Entwicklung der zeichnerischen Begabung

(The Development of the Gift of Drawing)

Munich, 1905 


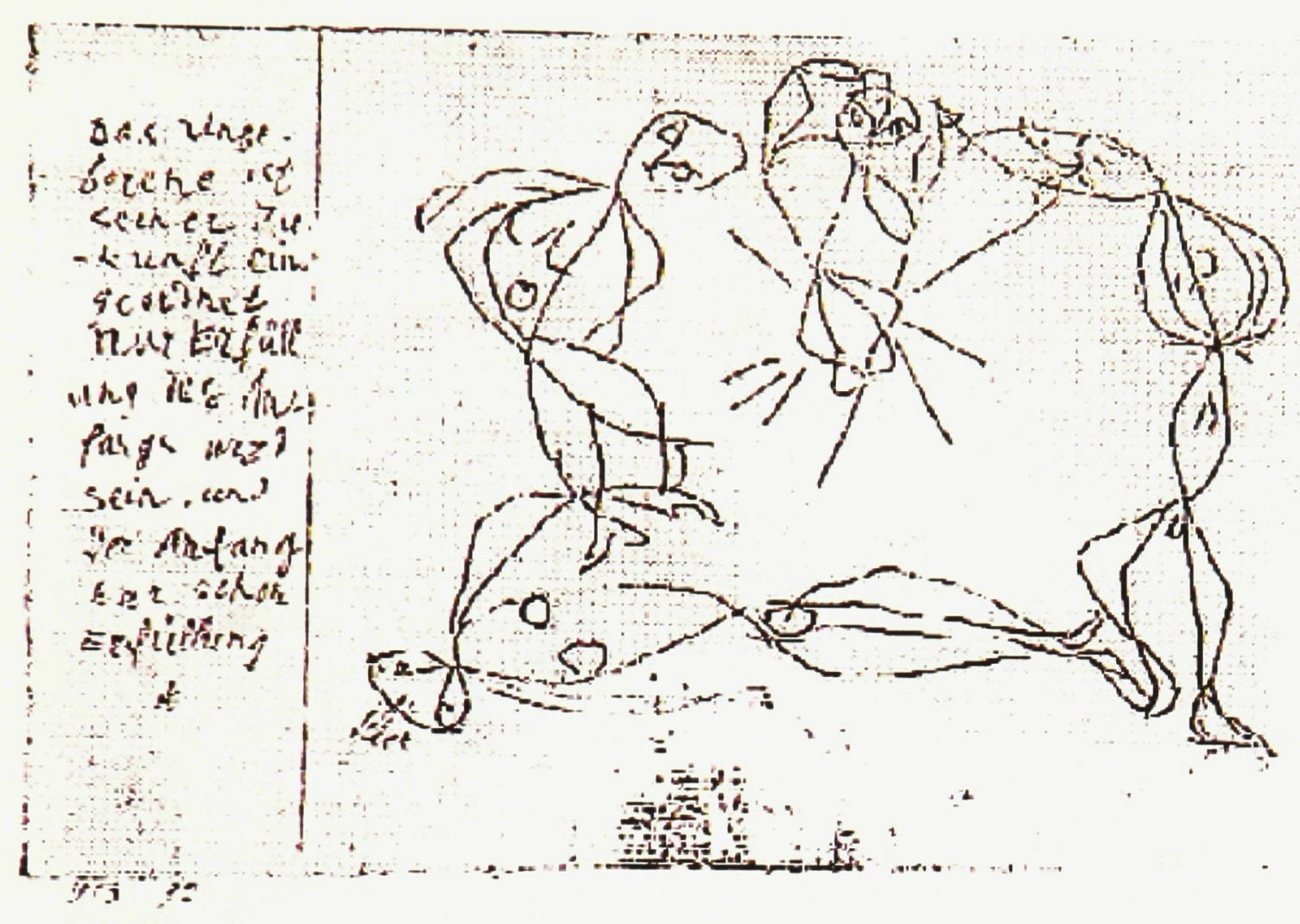

Figure 24

The Unborn is Integrated in Its Future. There Will Be Only Fulfillment Of The Beginning, And The Beginning Itself Was Already Fulfillment, 1913 Ink on paper on cardboard $15 \times 21 \mathrm{~cm}$

Private collection, Germany 


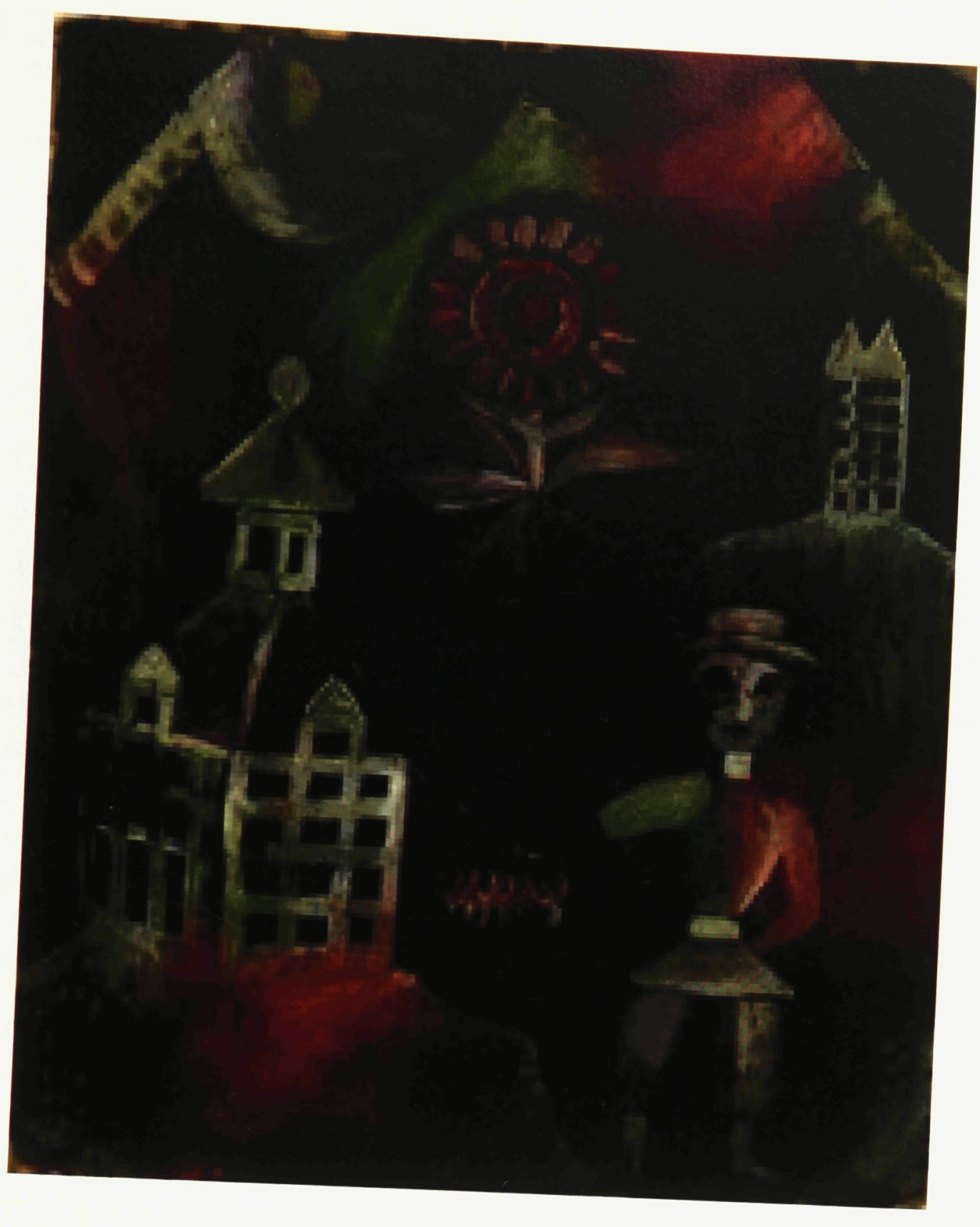

Figure 25

Schoolhouse, 1920

Oil on paper on cardboard

37 x $29 \mathrm{~cm}$

The Art Institute of Chicago

Collection of Mr. and Mrs. Leigh B. Block 


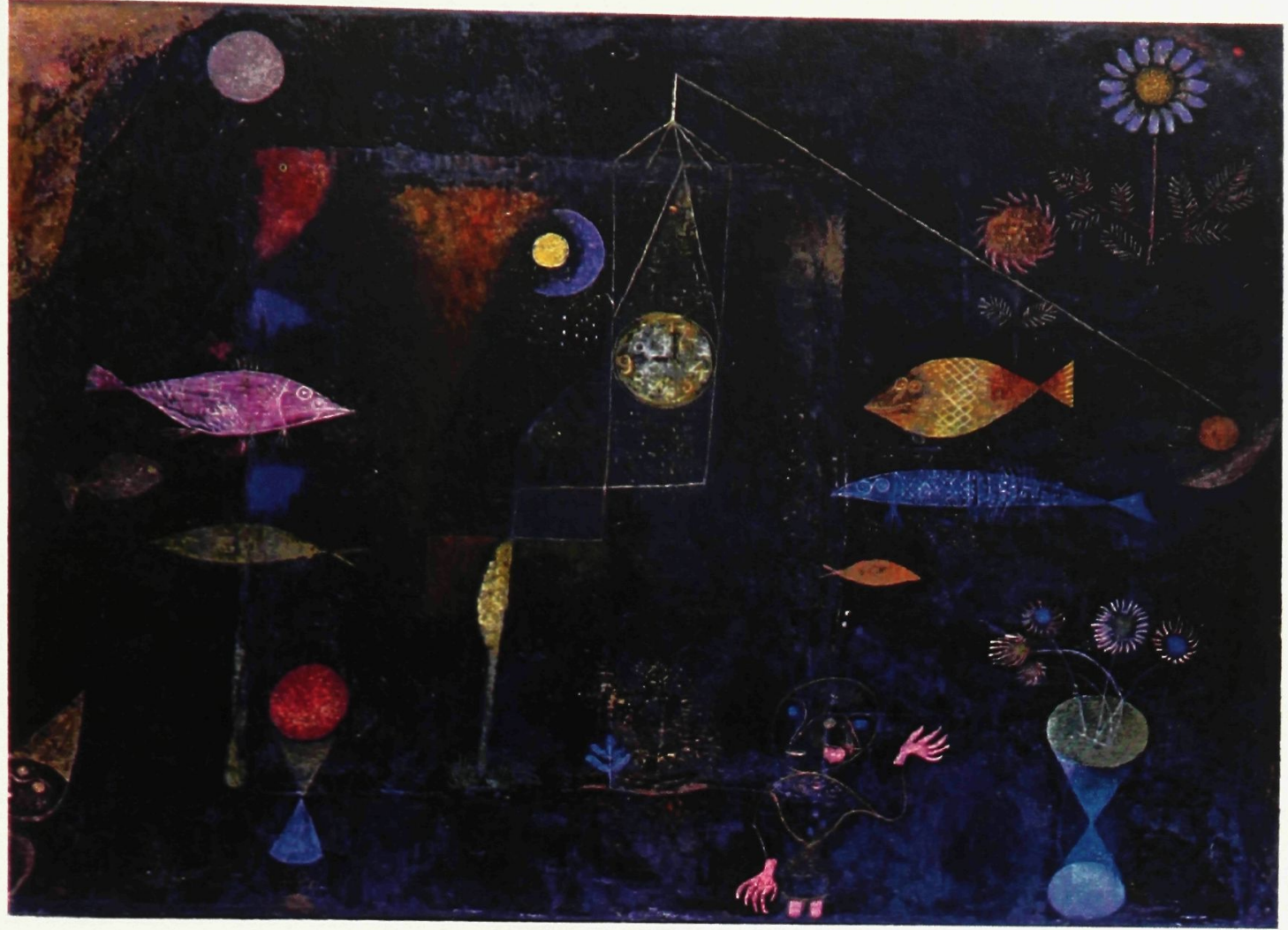

Figure 26

Fish Magic, 1925

Oil and watercolour on canvas

$77.5 \times 98.4 \mathrm{~cm}$

Philadelphia Museum of Art 


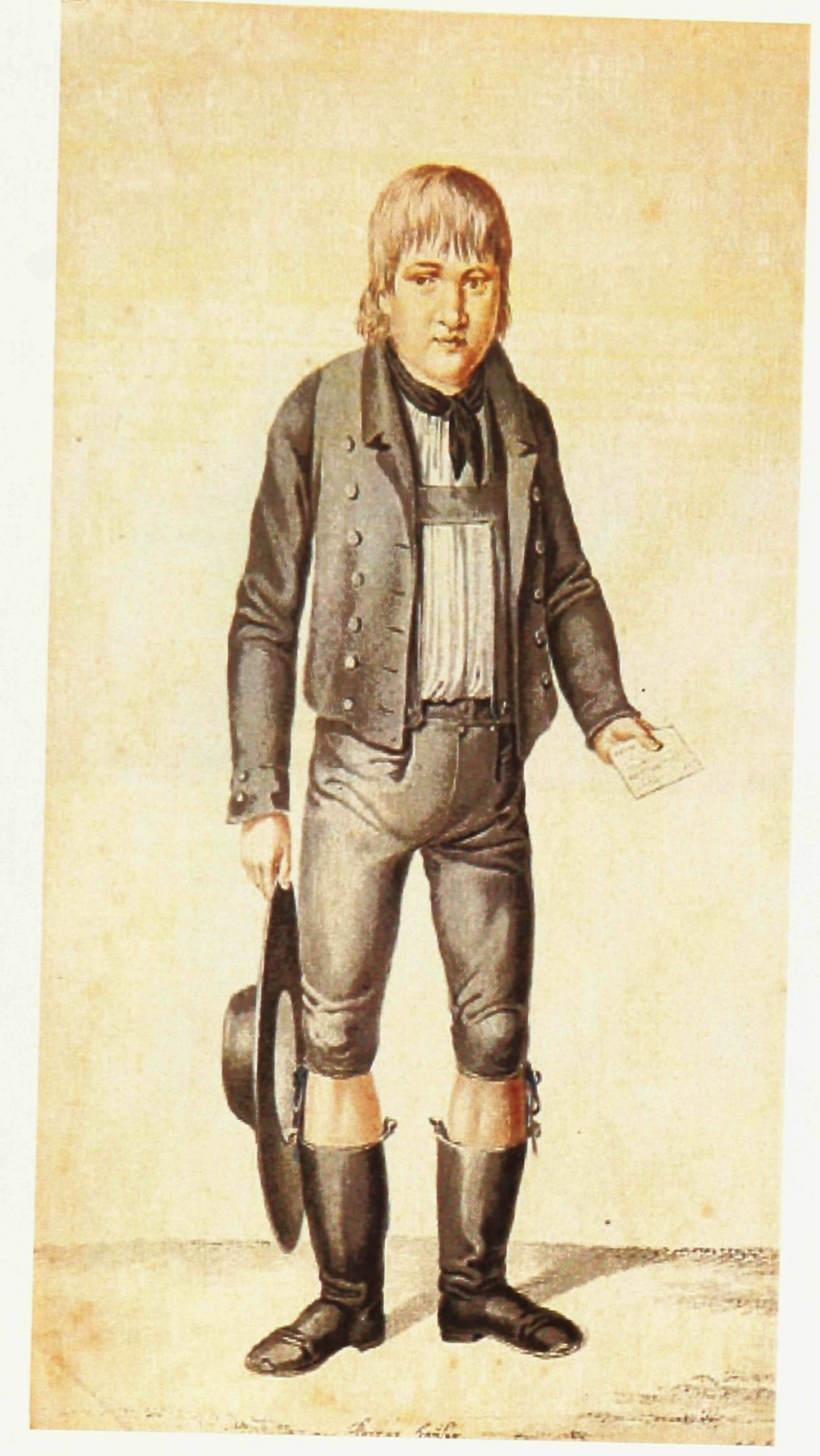

Figure 27

Johann Georg Laminit

The Young Kaspar Hauser, 1828-9

British Library 


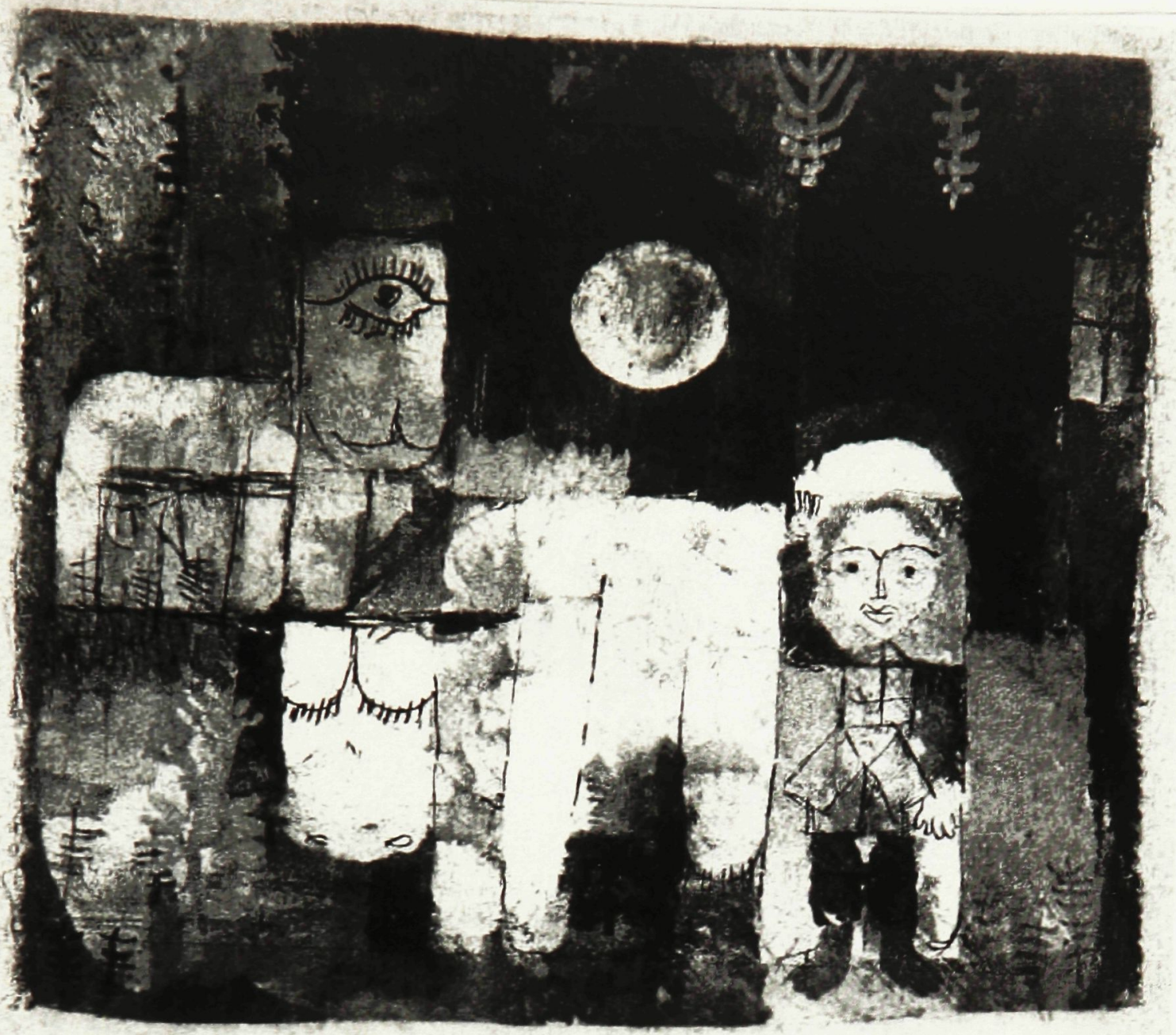

Figure 28

Sexual Discoveries of a Boy, 1918

Watercolour, ink, and plaster on paper on cardboard

$22.8 / 22 \times 24 \mathrm{~cm}$

Private collection, Switzerland 


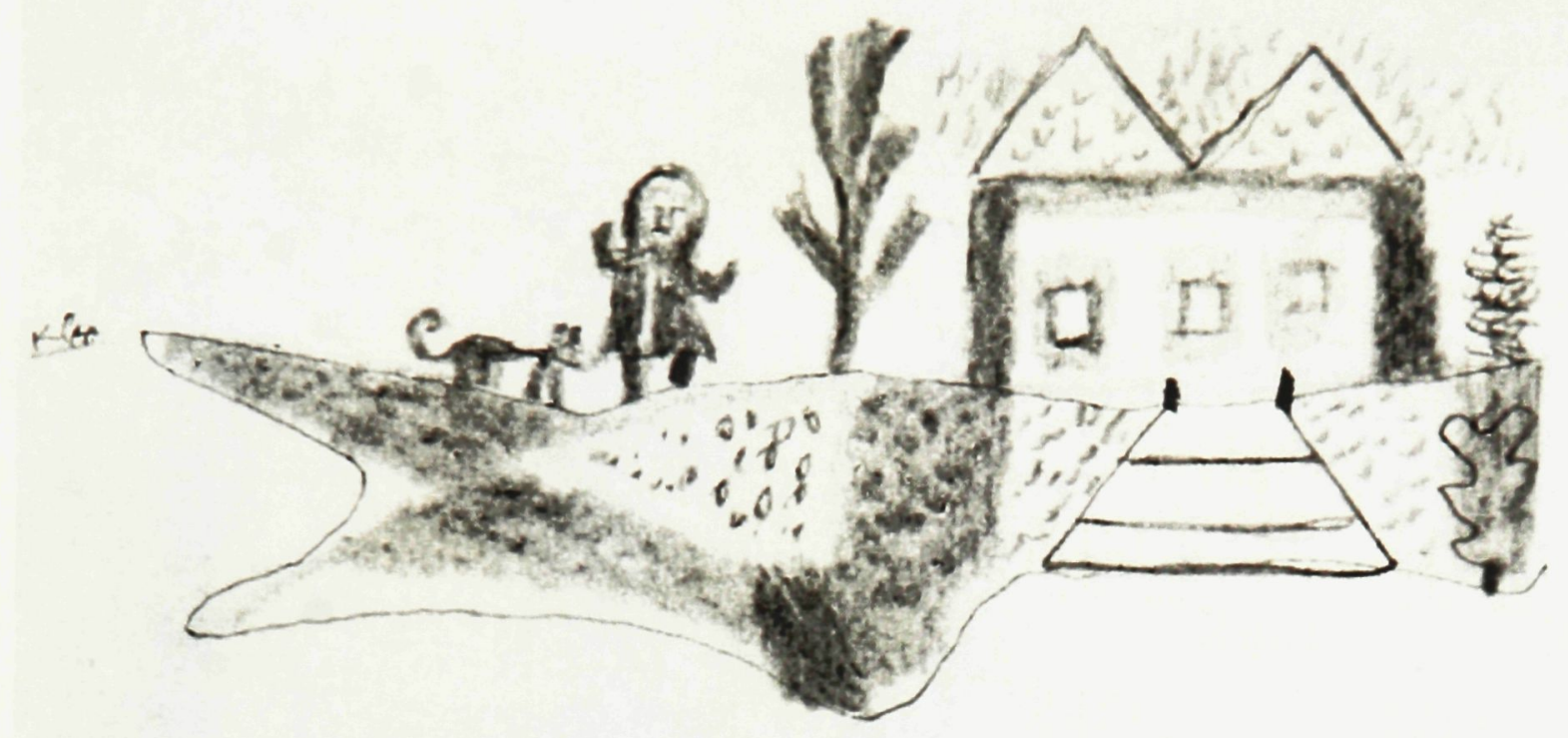

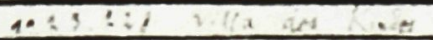

Figure 29

A Child's Villa, 1923

Pencil on paper on cardboard

$22 \times 28.7 \mathrm{~cm}$

Private collection, Switzerland 


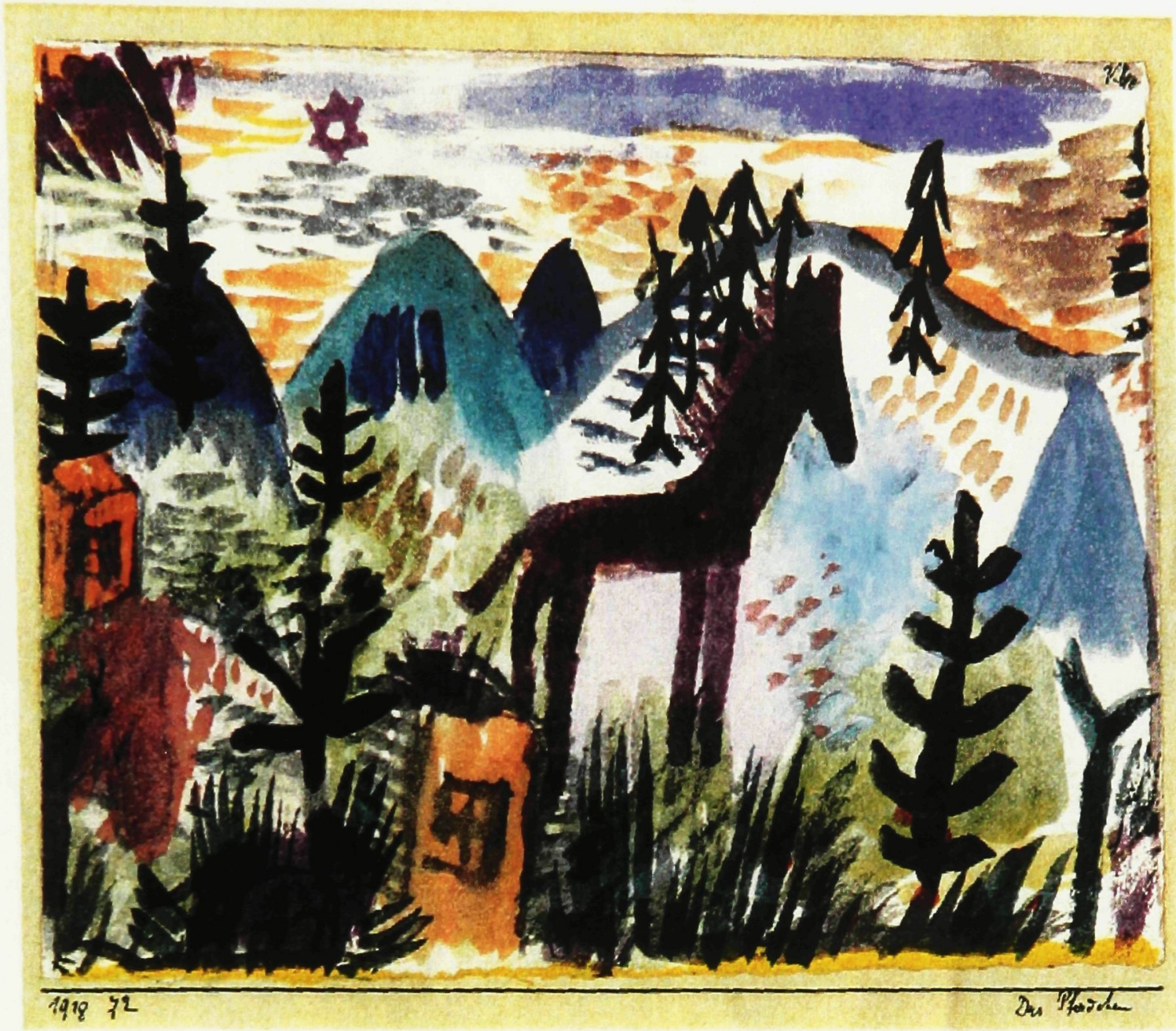

Figure 30

The Pony, 1918

Watercolour on paper on cardboard $13.5 \times 21.2 \mathrm{~cm}$

Location unknown 


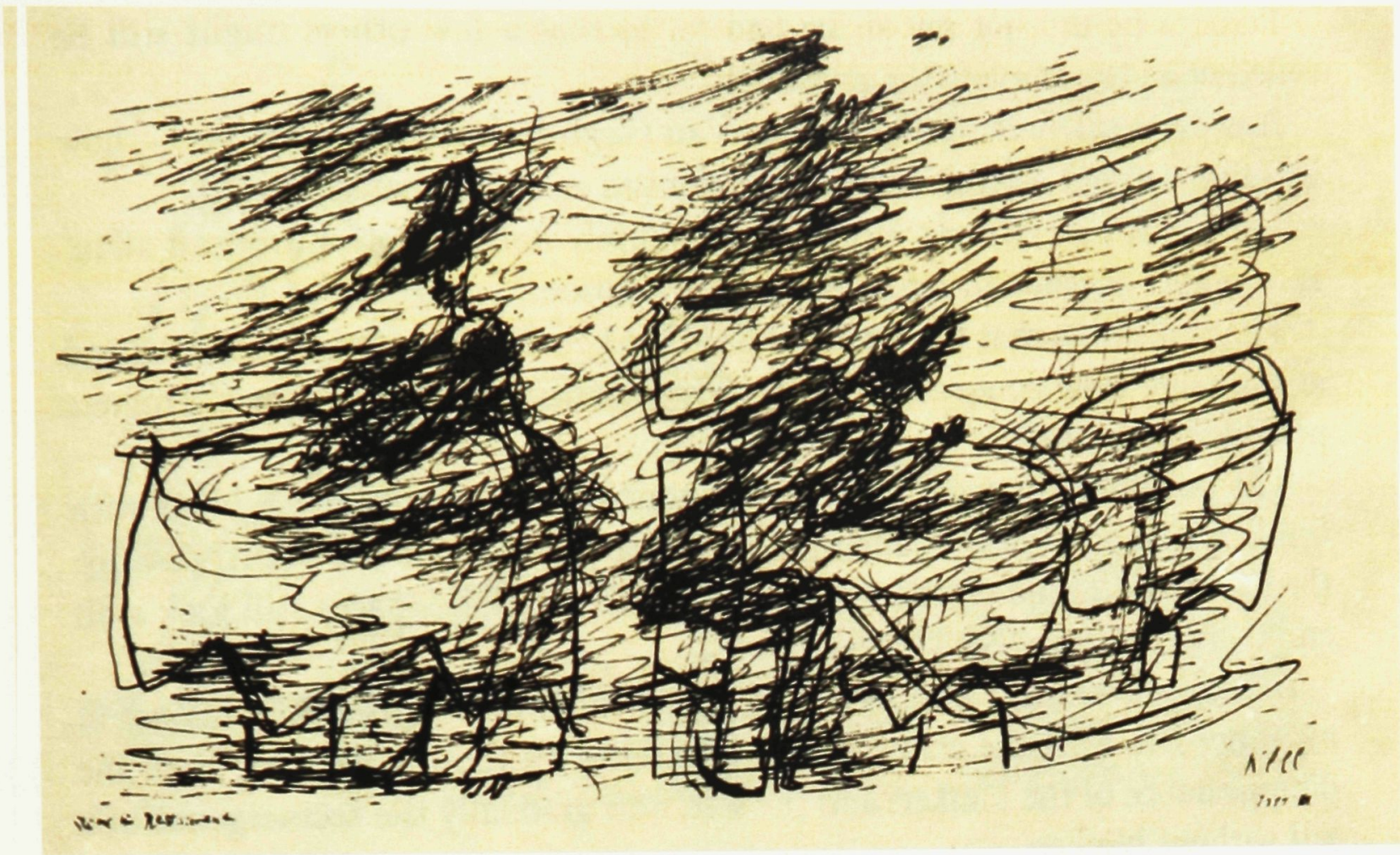

Figure 31

Scene in the Restaurant, 1911

Pencil and ink on paper on cardboard

$13 \times 23 \mathrm{~cm}$

Felix Klee collection, The Zentrum Paul Klee 


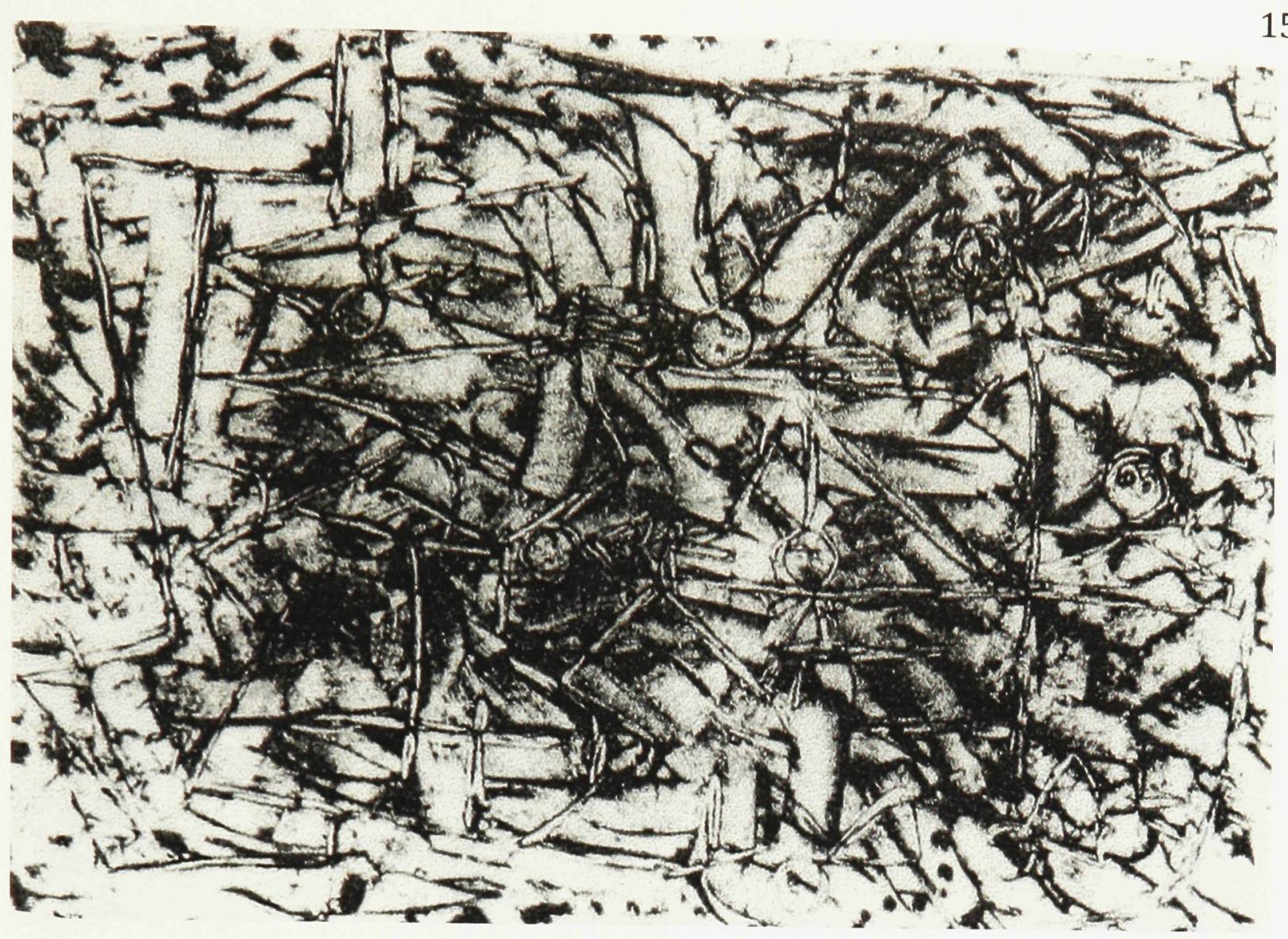

Figure 32

Kindergarten, 1939

Coloured paste and ink on paper, mounted on cardboard

$29.4 \times 20.7 \mathrm{~cm}$

Private collection, U.S.A. 


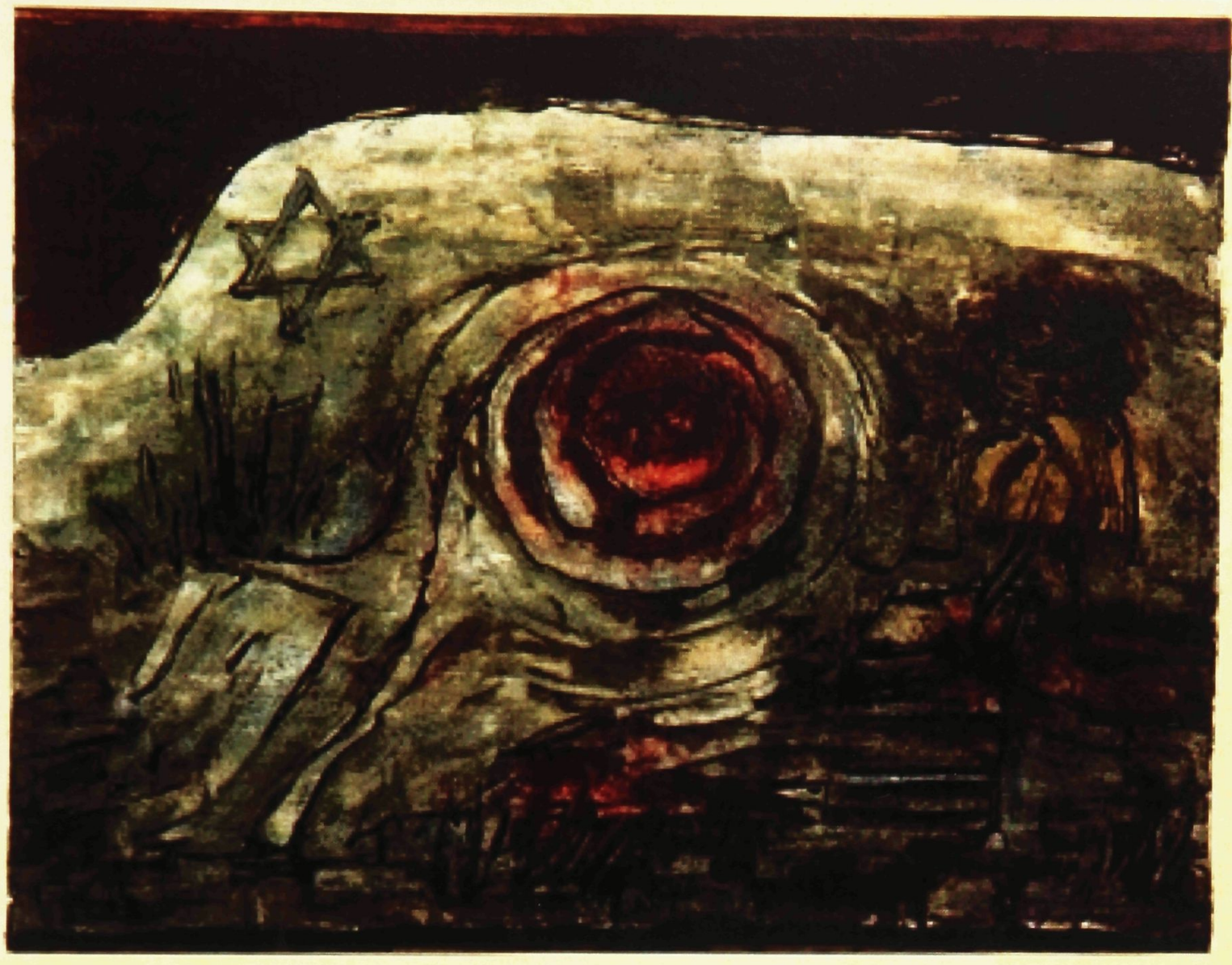

Figure 33

Childhood of the Chosen One, 1930

Coloured paste and watercolour on paper, above and below edge strip with watercolour and ink, on cardboard

$23.9 \times 30.5 \mathrm{~cm}$

Sammlung Rosengart, Luzern 


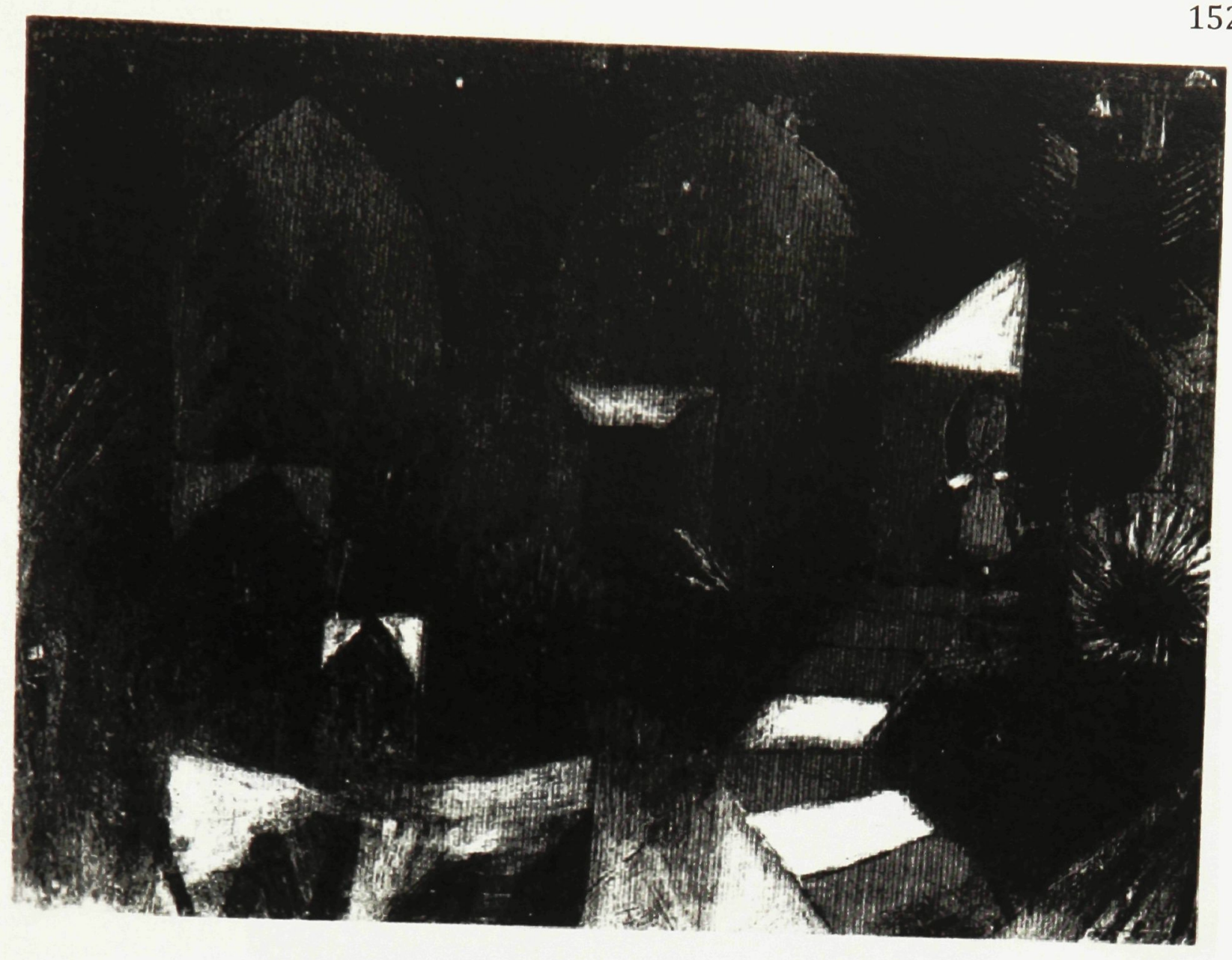

Figure 34

Child as Hermit, 1920

Oil and tusche on paper

$19.3 \times 26.4 \mathrm{~cm}$

Kasama Nichido Museum of Art, Kasami-City, Japan 


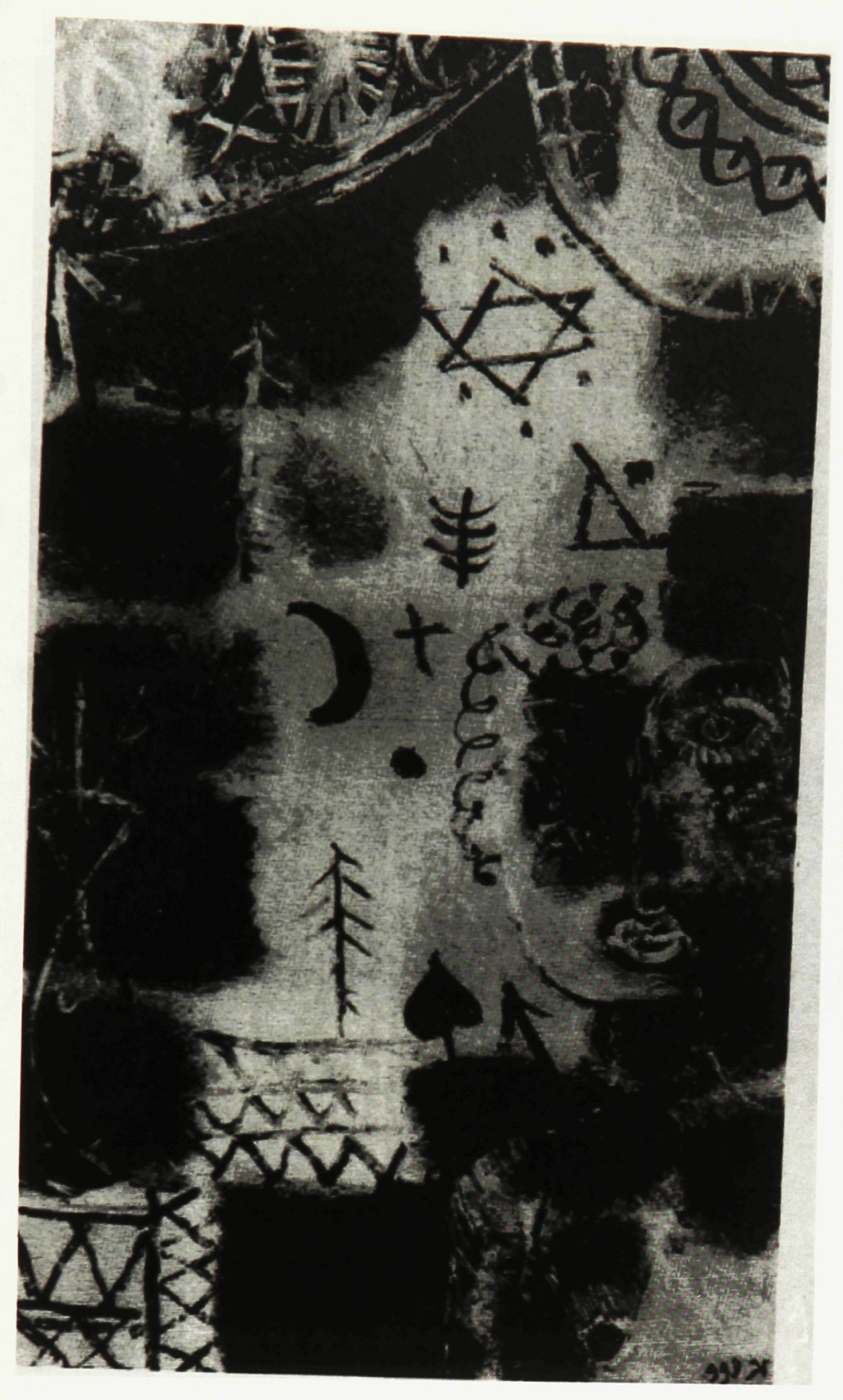

Figure 35

Oracle, 1919

Oil on paper on cardboard

$33.8 \times 19 \mathrm{~cm}$

Location unknown 


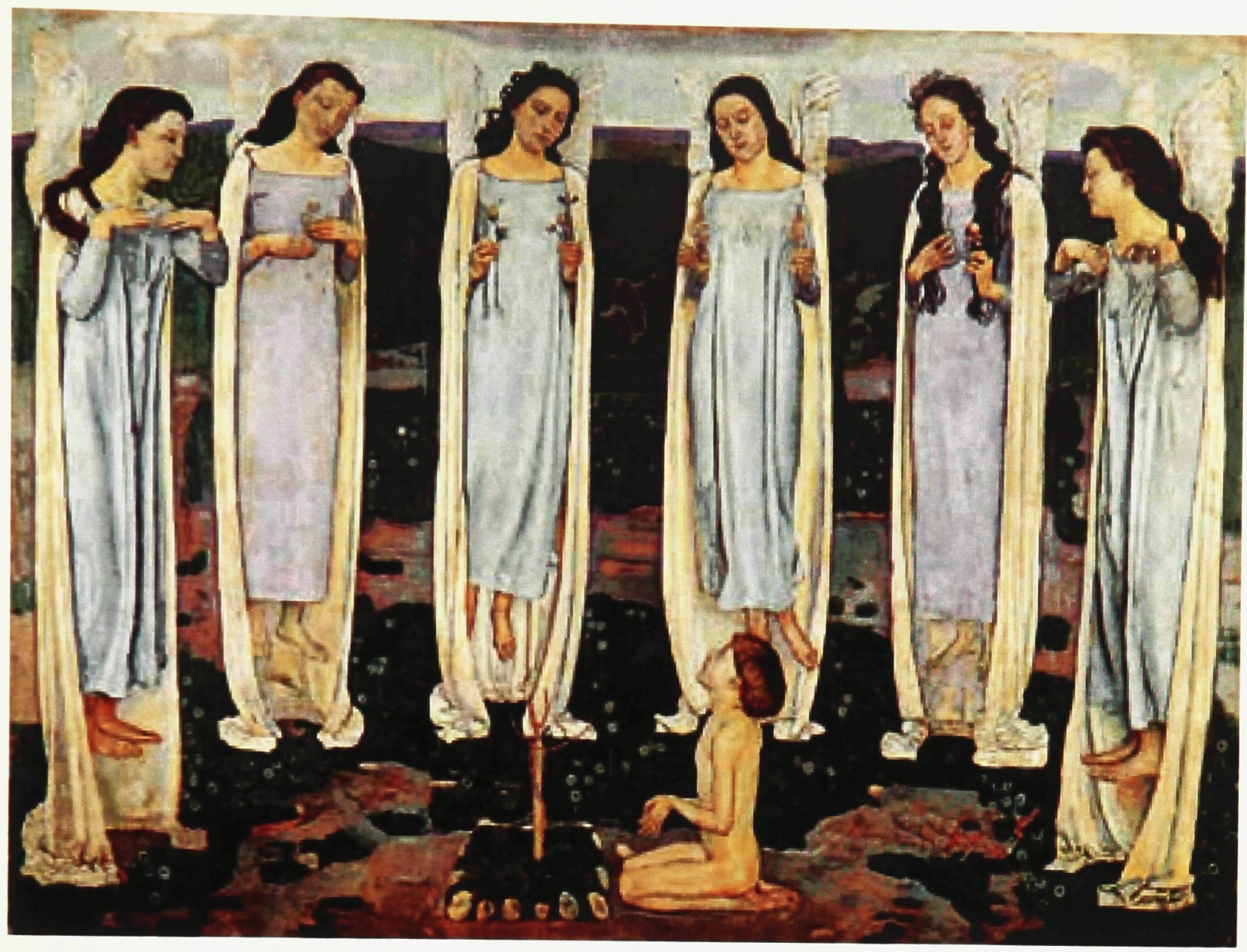

Figure 36

Ferdinand Holder

The Chosen One, 1893-94

Tempera and oil on canvas 219 x $296 \mathrm{~cm}$

Kunstmuseum, Bern 


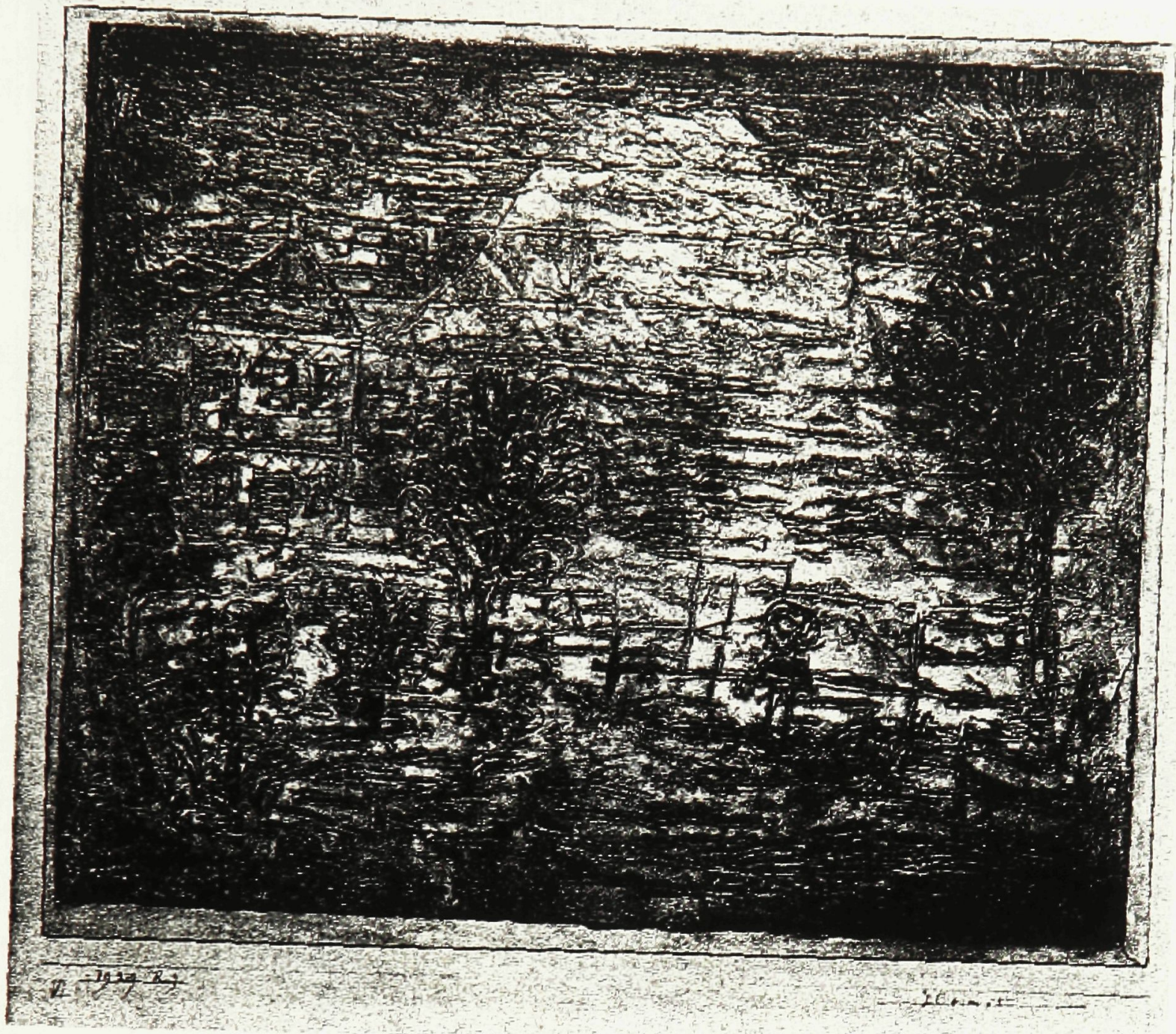

Figure 37

Homeland, 1929

Oil, ink and watercolour on cardboard

$28.4 \times 37.5 \mathrm{~cm}$

Location unknown 


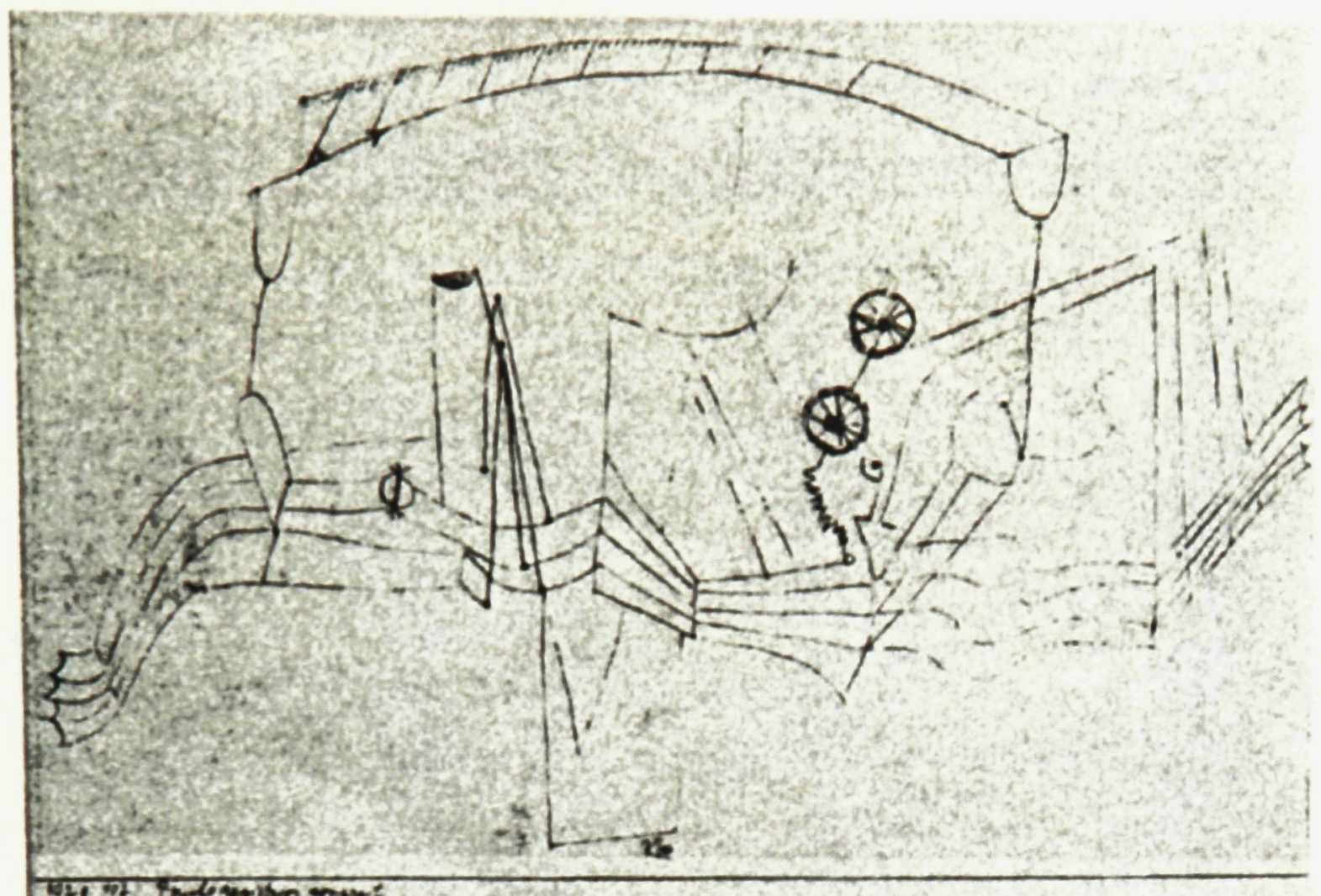

Figure 38

Psycho-Recording Apparatus, 1920

Pen and ink on paper mounted on cardboard $21.6 \times 29.4 \mathrm{~cm}$

Norton Museum of Art, West Palm Beach

Donation of Melvin and Barbara Nessel 


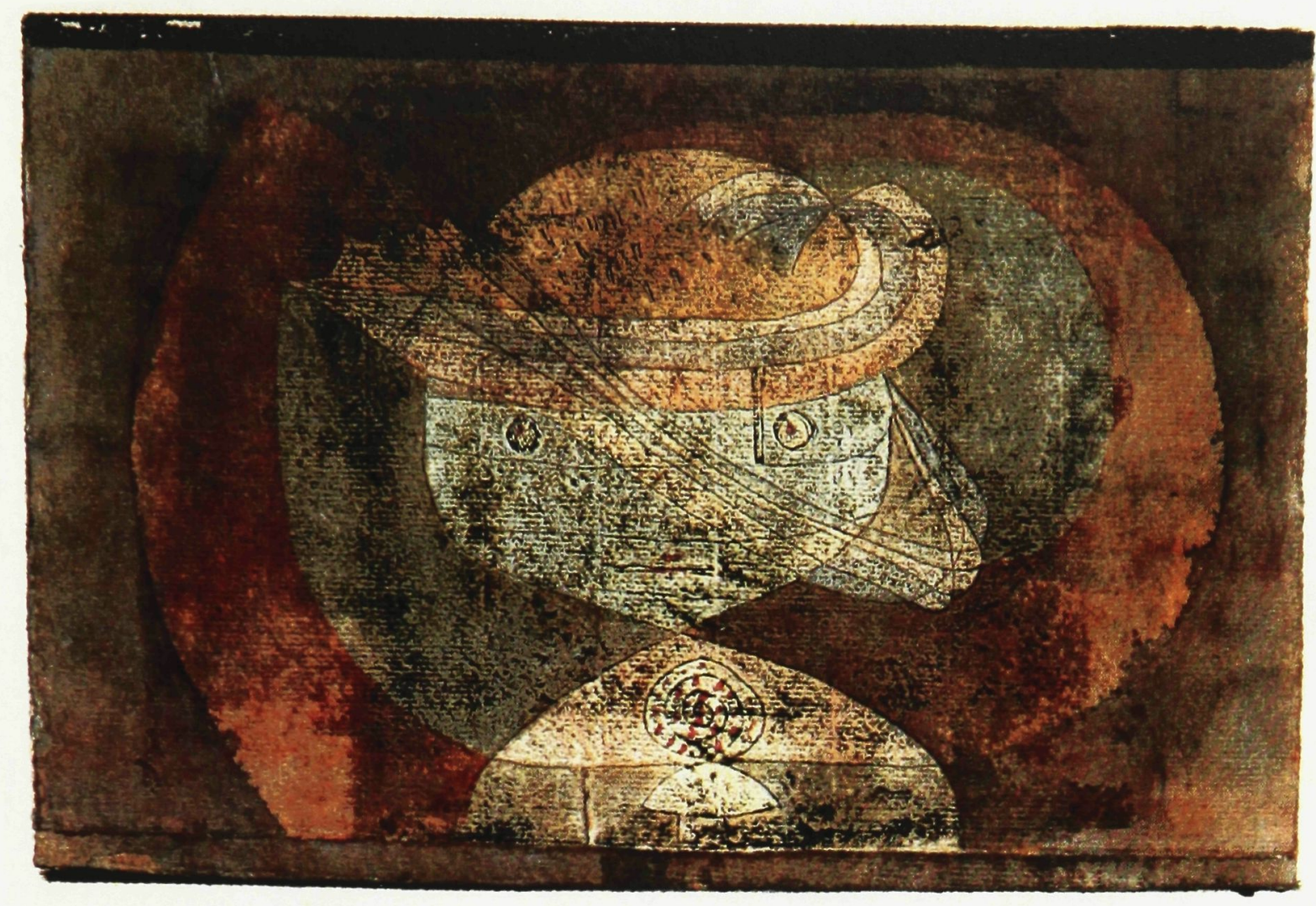

Figure 39

Movement Around a Child, 1928

Oil paint and watercolour on paper, above and below edge strip with watercolour and ink, on cardboard

$20.2 \times 30.2 \mathrm{~cm}$

The Saint Louis Art Museum

Donation of Mrs. Richard K. Weil 


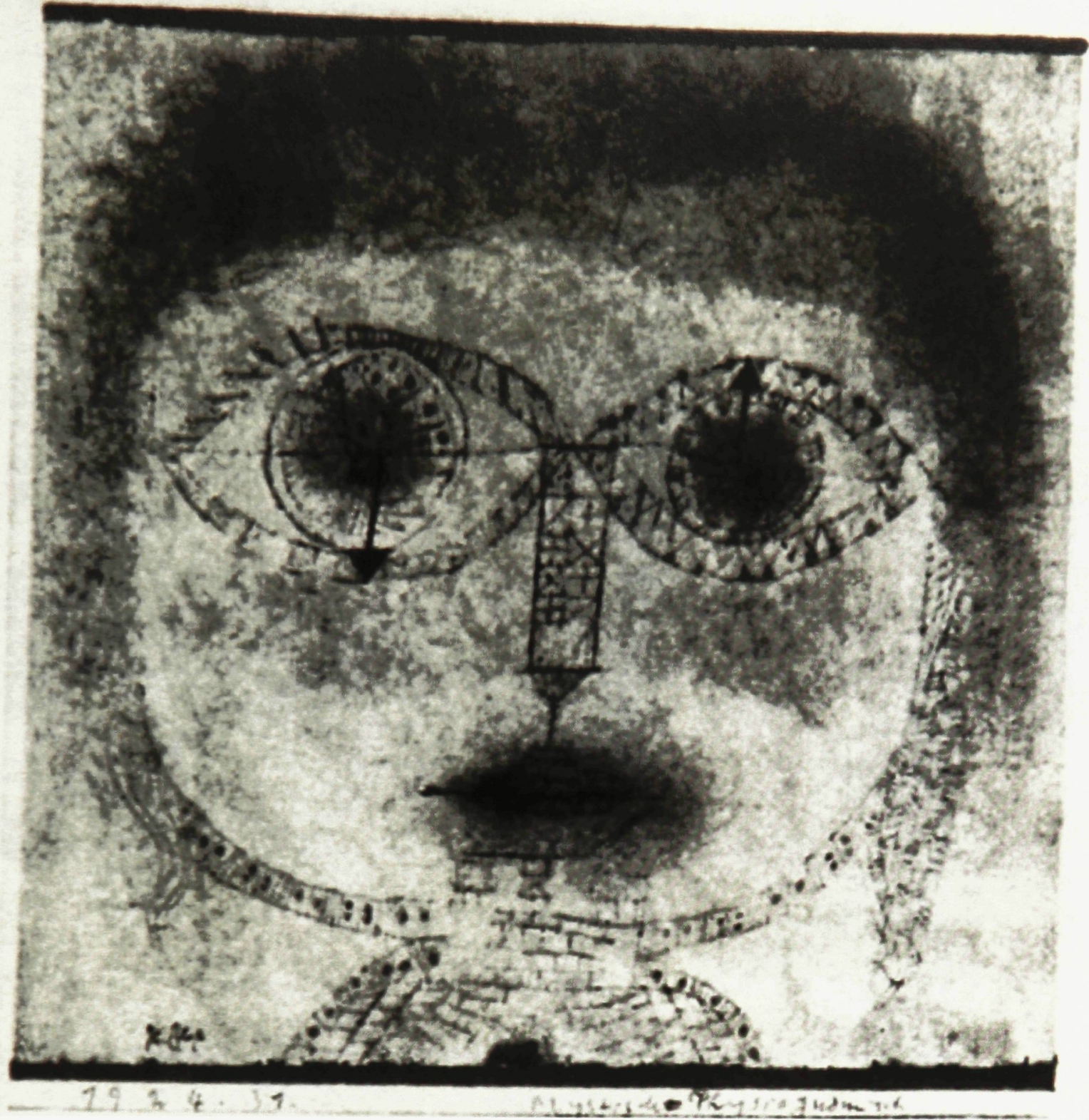

Figure 40

Mystical-Physiognomic, 1924

Ink and watercolour on paper, above and below edge strip with watercolour and ink, on cardboard

$13.5 \times 13.5 \mathrm{~cm}$

Location unknown 


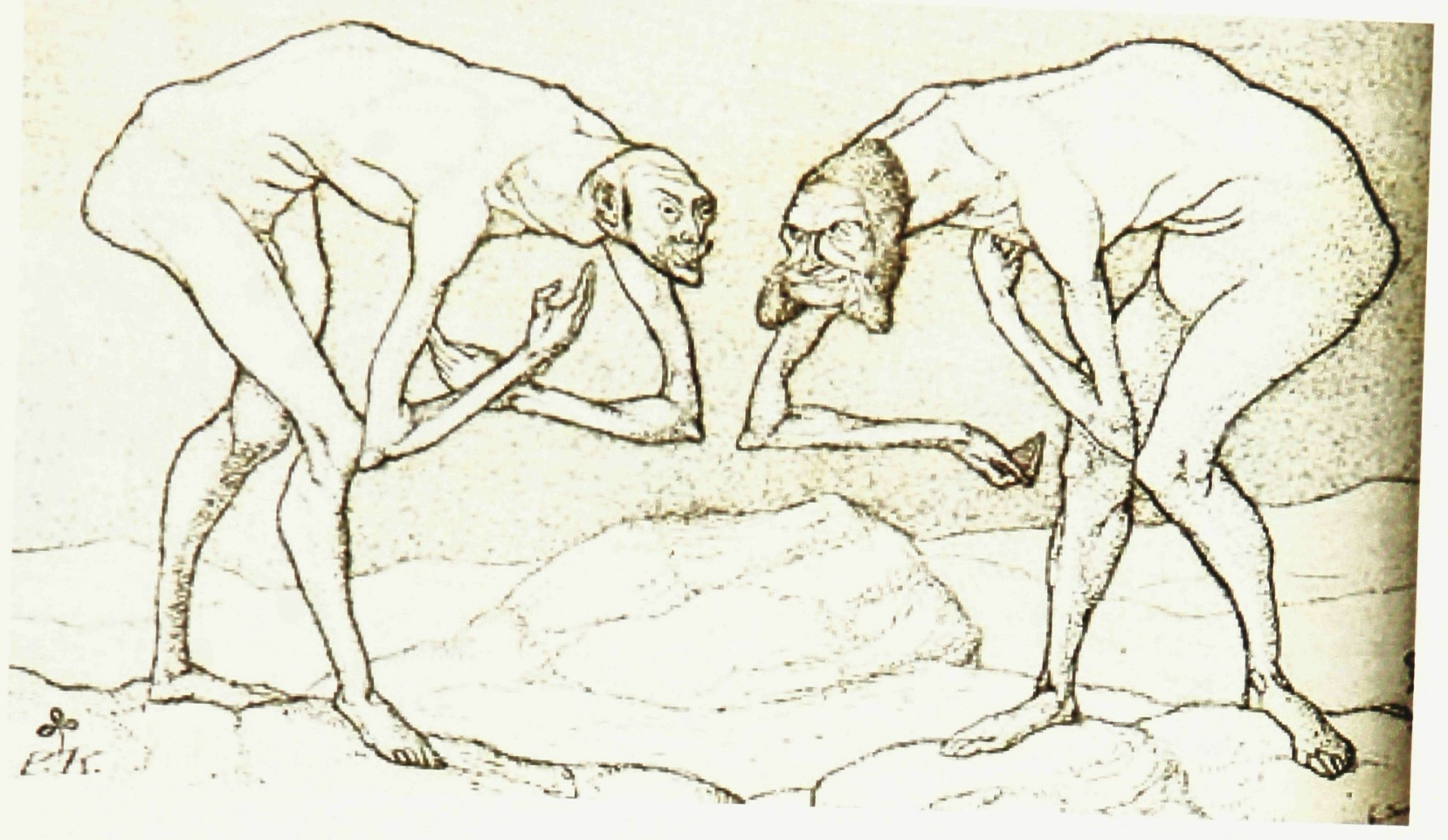

Figure 41

Two Men Meet: Each Supposing The Other To Be of Higher Rank, 1902 Etching on zinc

$11.8 \times 22.6 \mathrm{~cm}$

Paul Klee-Stiftung, The Zentrum Paul Klee 


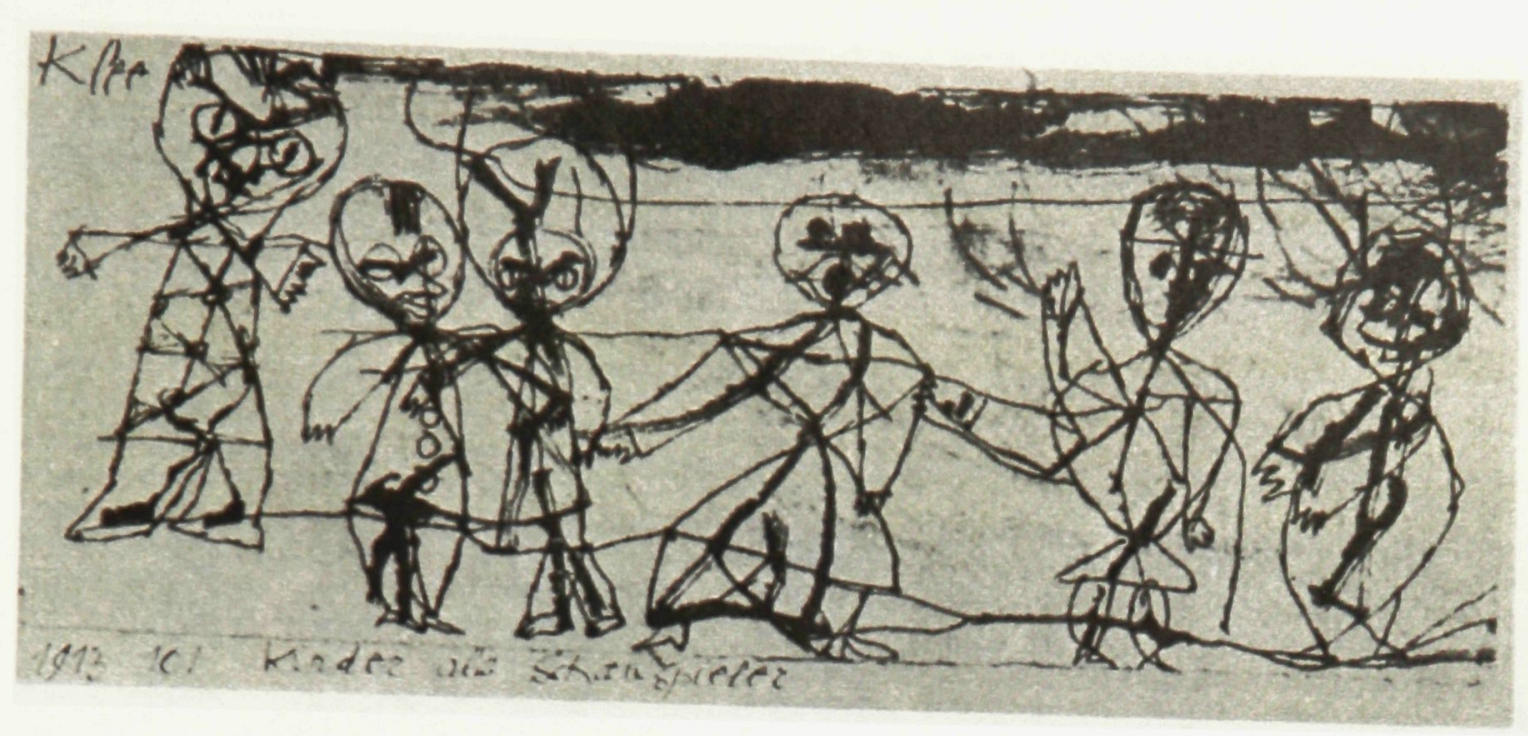

Figure 42

Children as Actors, 1913

Ink and pencil on paper

$6.6 \times 16.5 \mathrm{~cm}$

Paul Klee-Stiftung, The Zentrum Paul Klee 


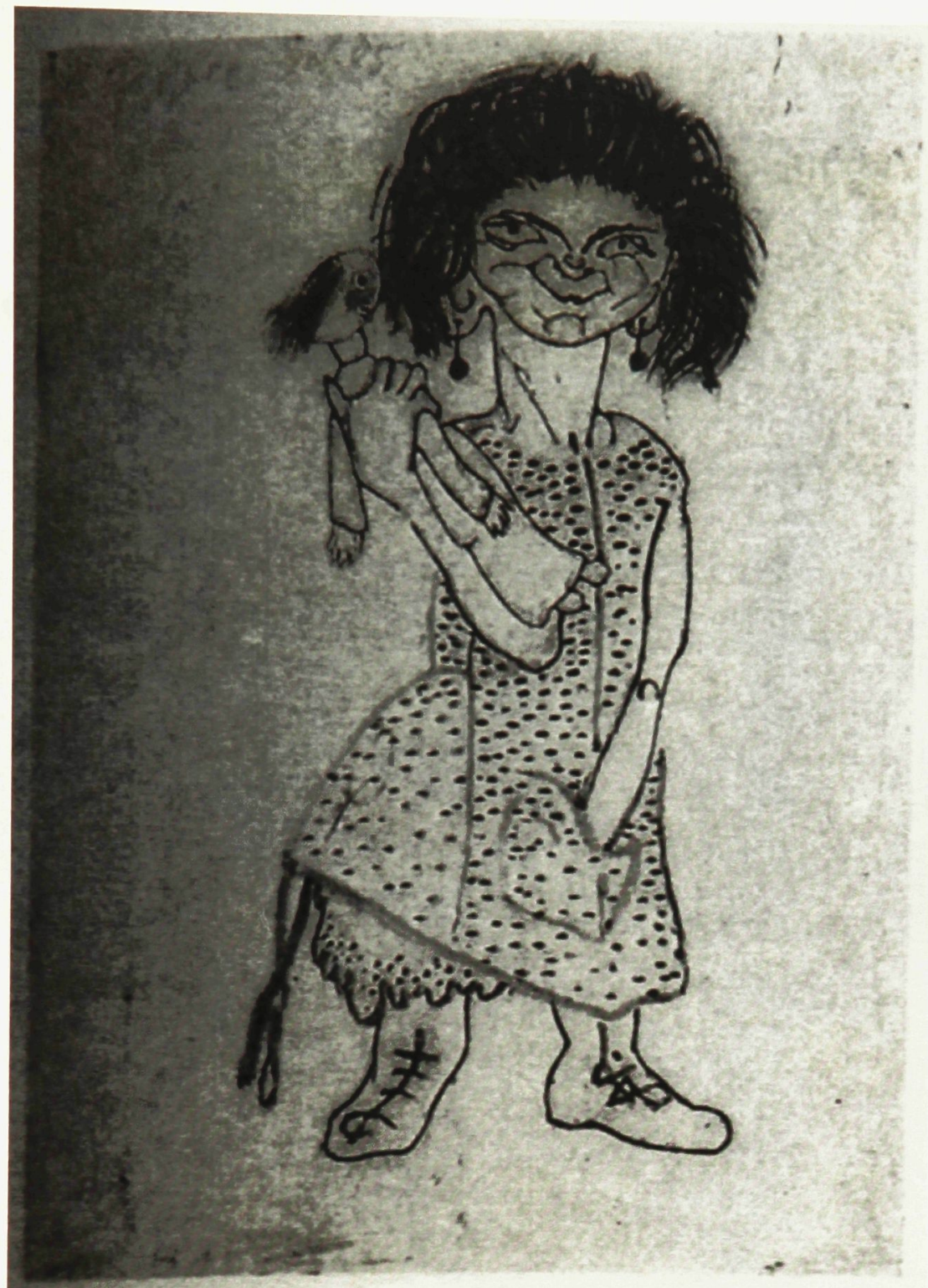

Figure 43

Girl With Doll, 1905

Painting behind glass with watercolour $18 \times 13 \mathrm{~cm}$

Paul Klee-Stiftung, The Zentrum Paul Klee 


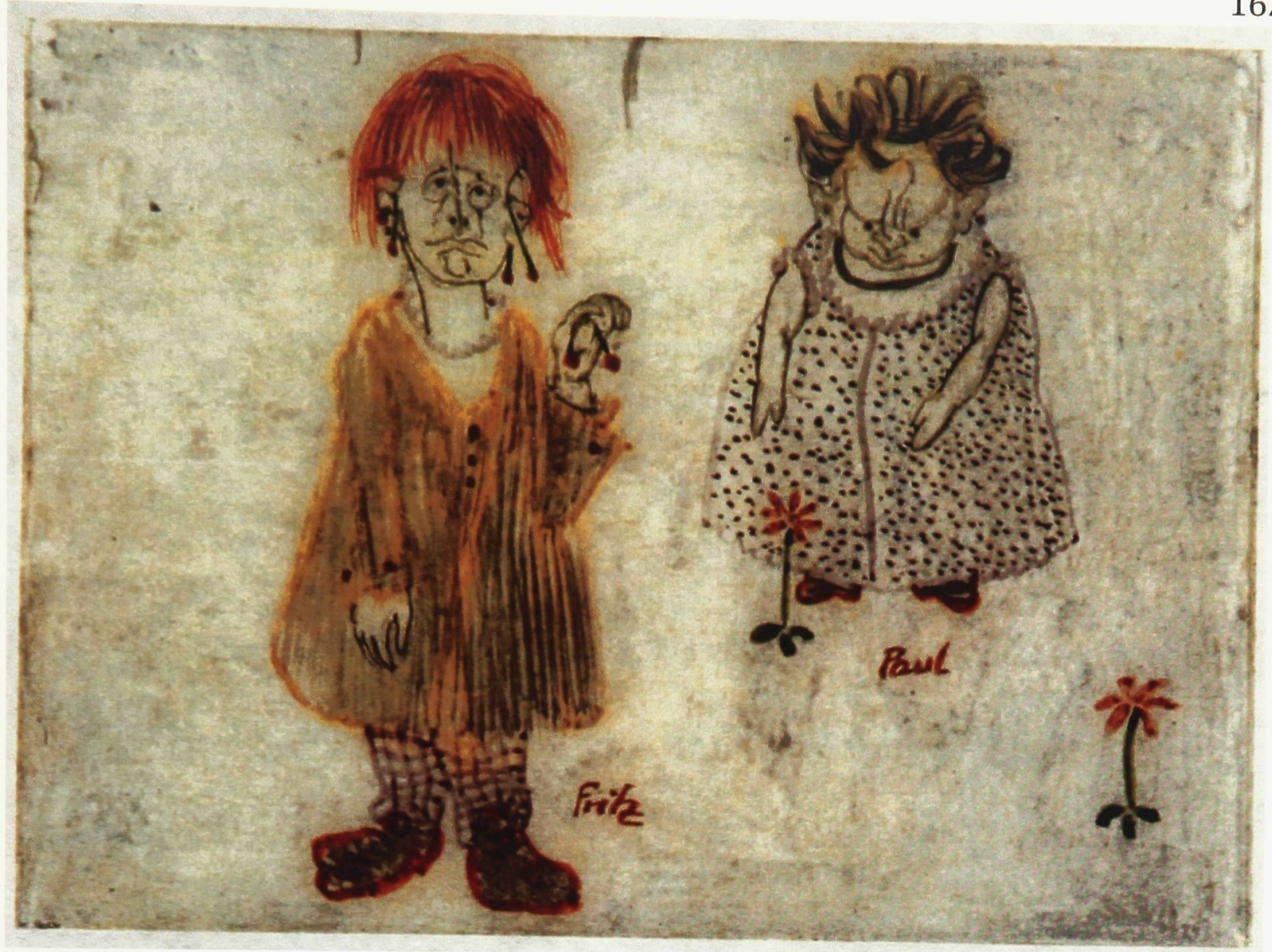

Figure 44

Paul and Fritz, 1905

Painting behind glass with watercolour

$13 \times 18 \mathrm{~cm}$

Paul Klee-Stiftung, The Zentrum Paul Klee 


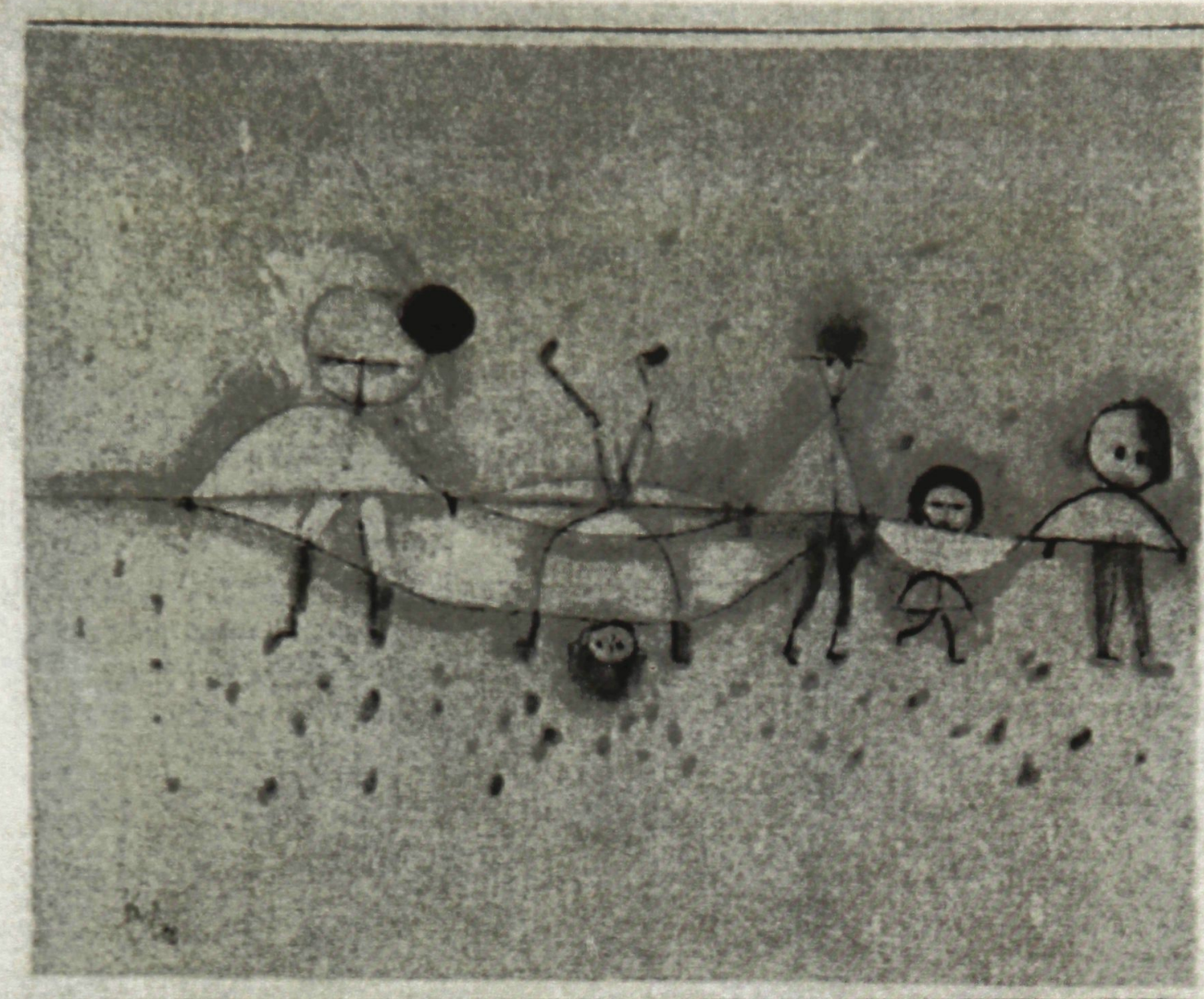

$\sqrt{4 \times 3} \times$

Figure 45

Children at Play Forming a Chain, 1928

Ink and watercolour on paper on cardboard

$38 \times 47 \mathrm{~cm}$

Galerie Thomas, Munich 


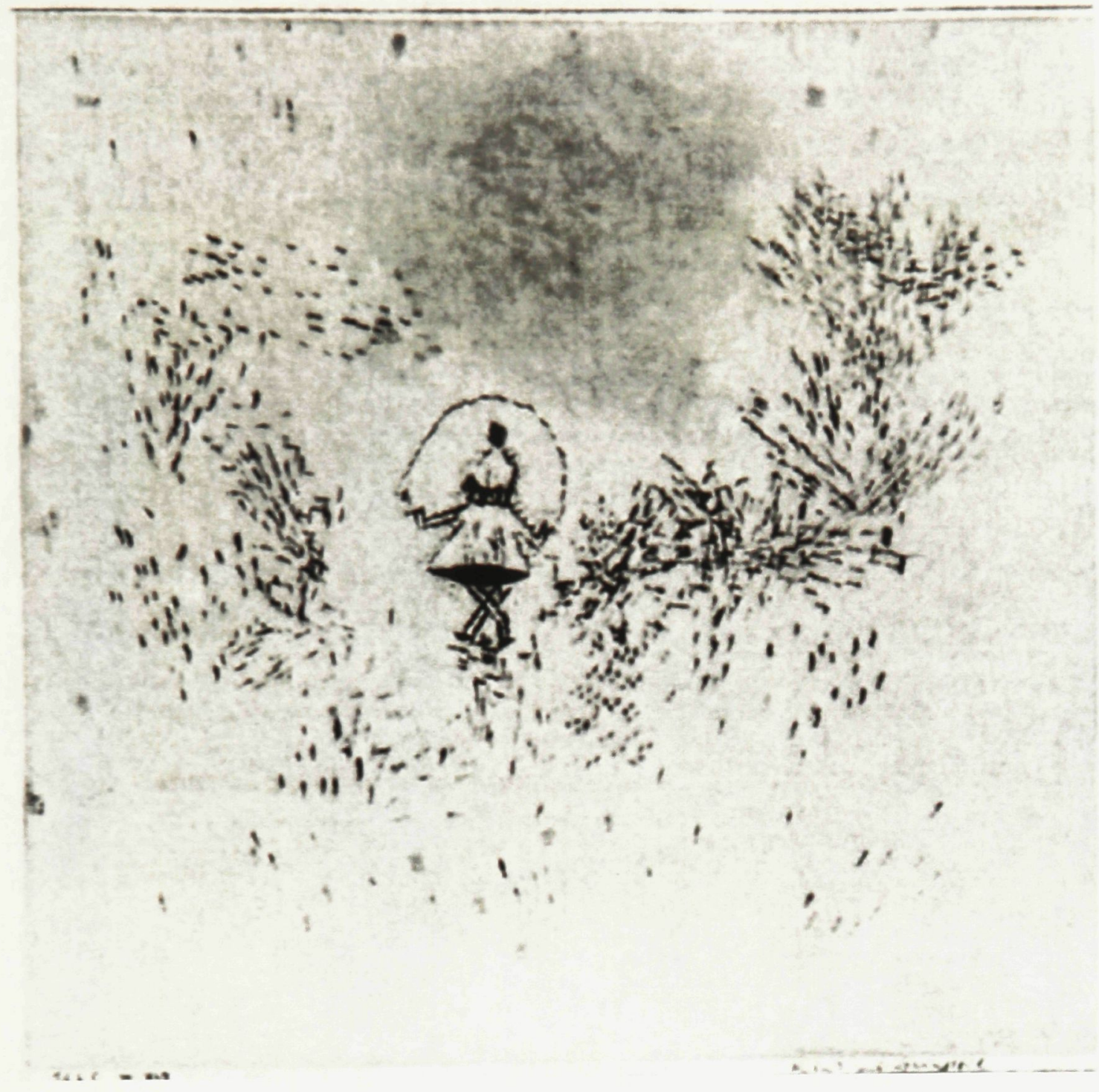

Figure 46

Child with Skipping Rope, 1925

Watercolour and paste on paper on cardboard $21 \times 21.6 \mathrm{~cm}$

Private collection, USA 


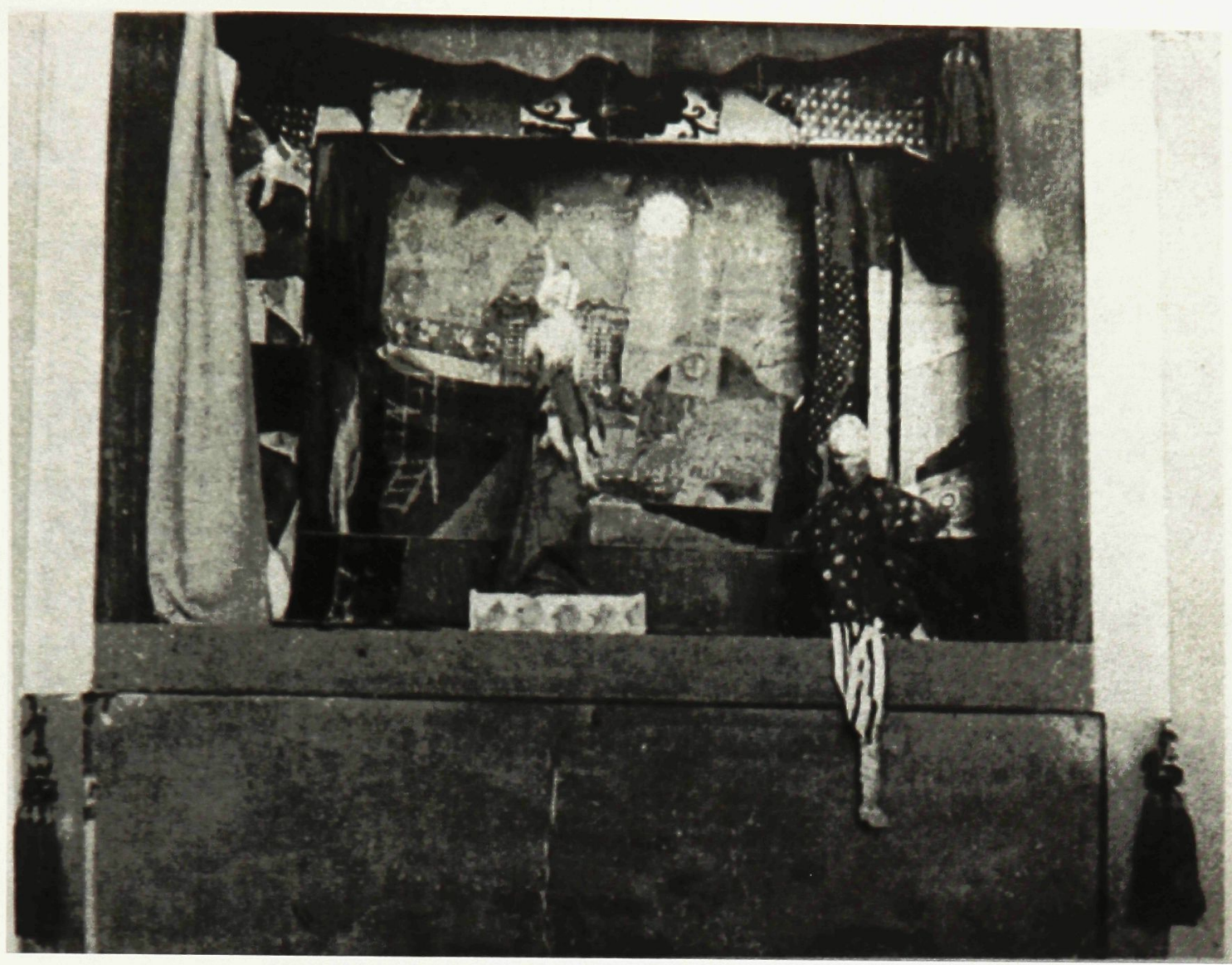

Figure 47

Sets for Punch and Judy Puppet Theater, 1922

Destroyed World War II

Photograph from Felix Klee, ed. Paul Klee: His Life and Work and Documents. Trans.

Richard and Clara Winston. New York: Braziller, 1962. 


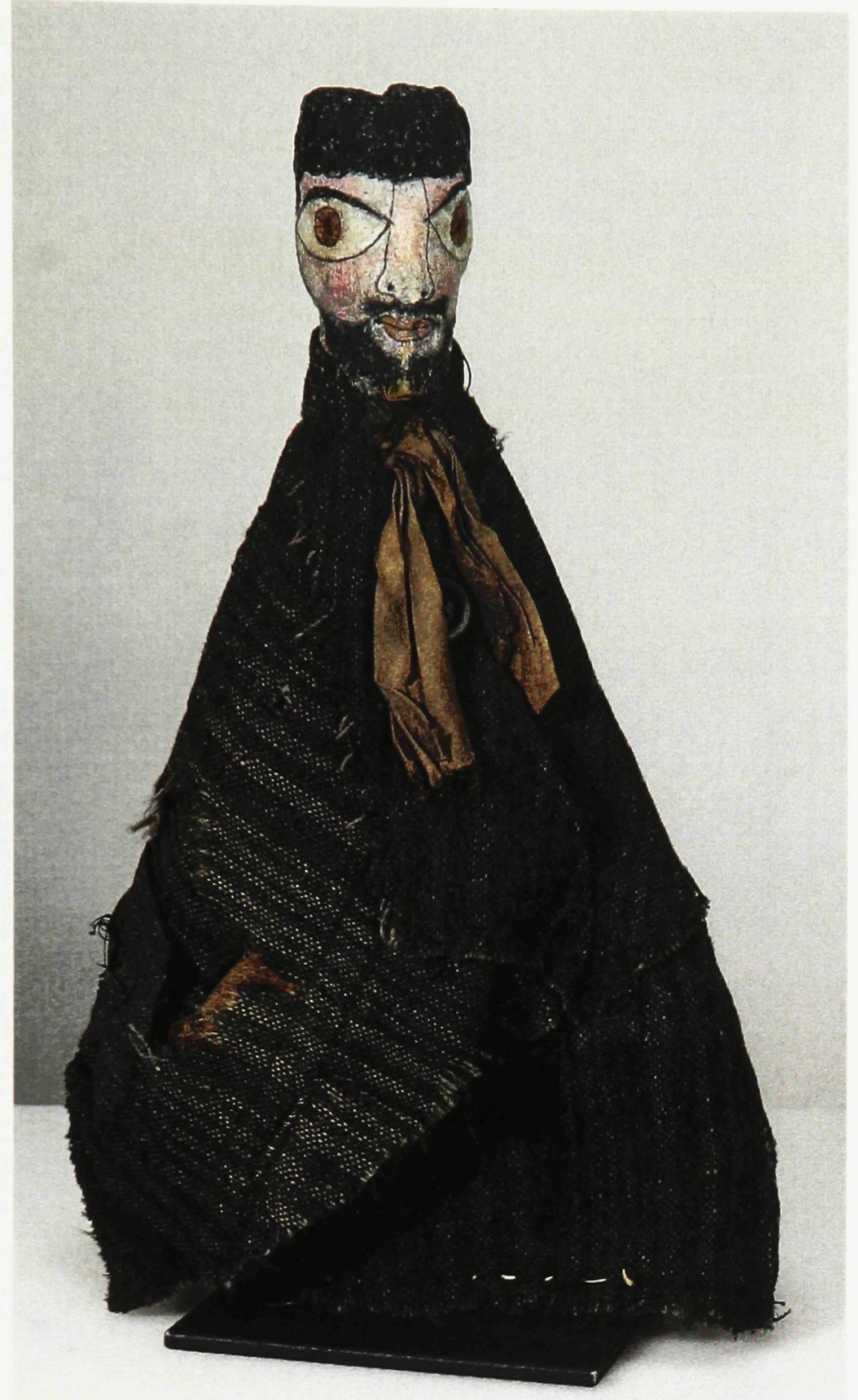

Figure 48

Self Portrait [Puppet], 1922

Head: cow bone and plaster; Robe: want material $38 \mathrm{~cm}$

Donation of Lily Klee, The Zentrum Paul Klee 


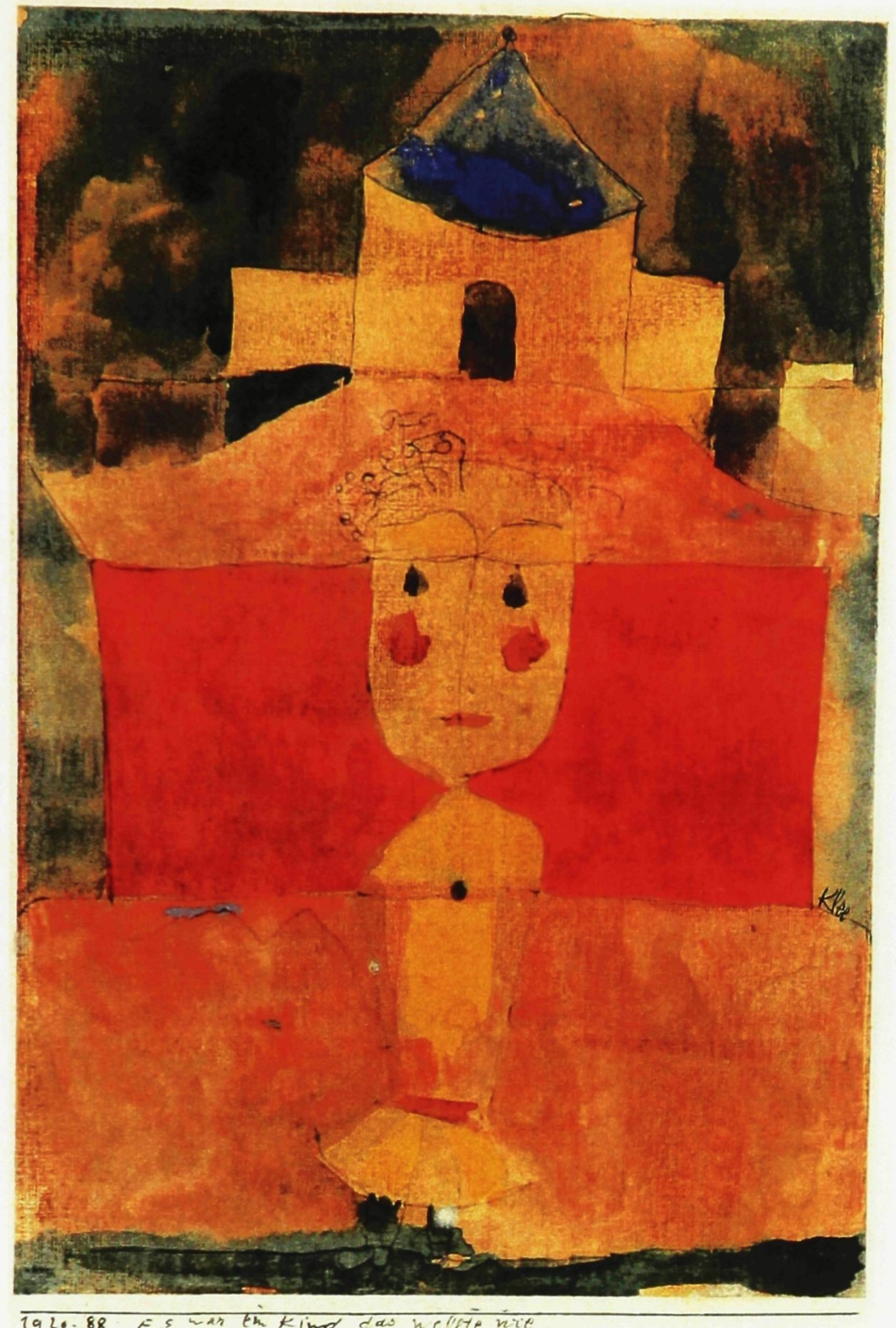

Figure 49

There Once was a Child Who Never Wanted, 1920

Ink and watercolour on paper on cardboard

$28.3 \times 18.7 \mathrm{~cm}$

Private collection, Switzerland 


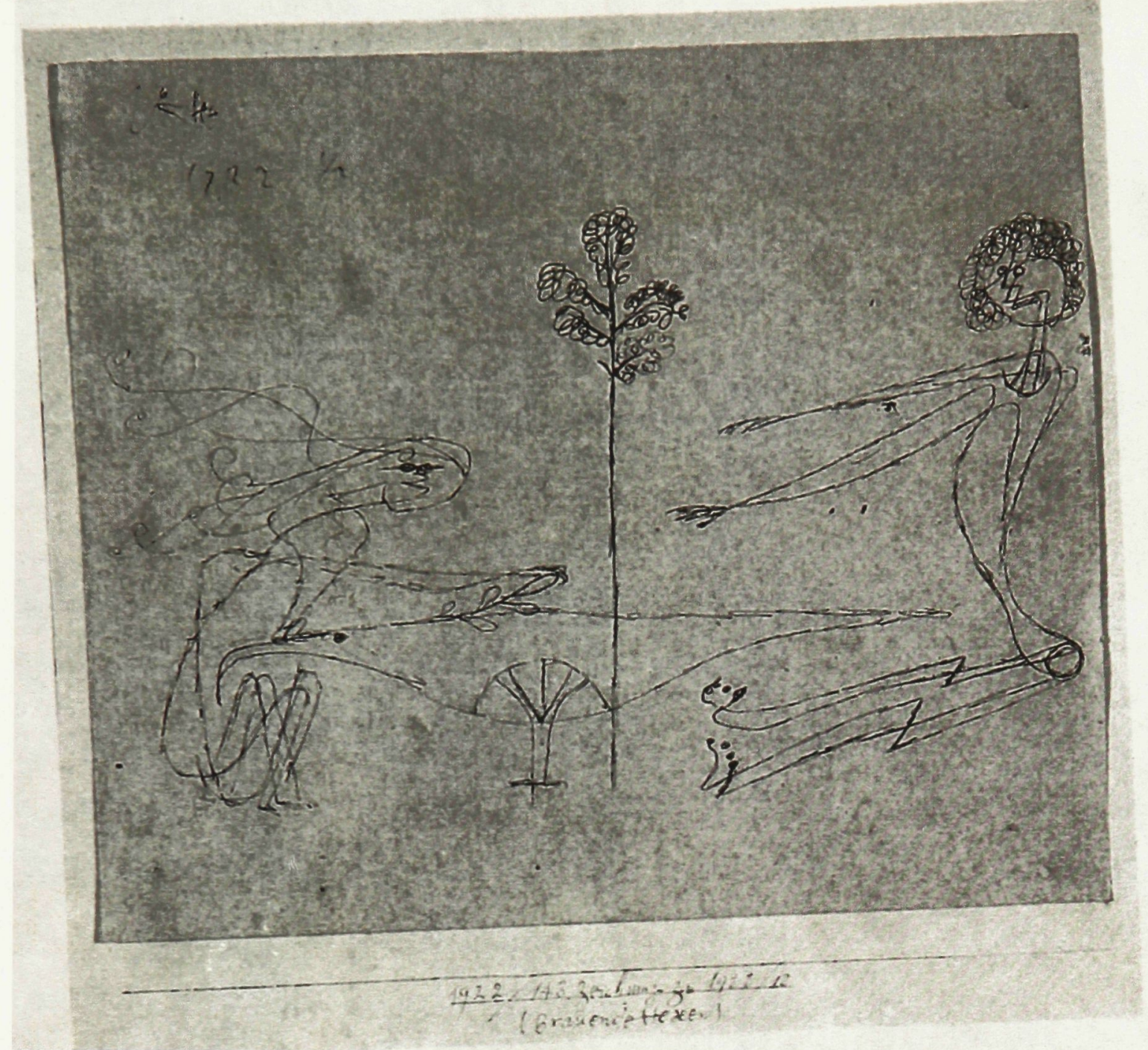

Figure 50

Brewing Witches, 1922

Ink on paper on cardboard

$18.8 \times 22 \mathrm{~cm}$

Private collection, USA 


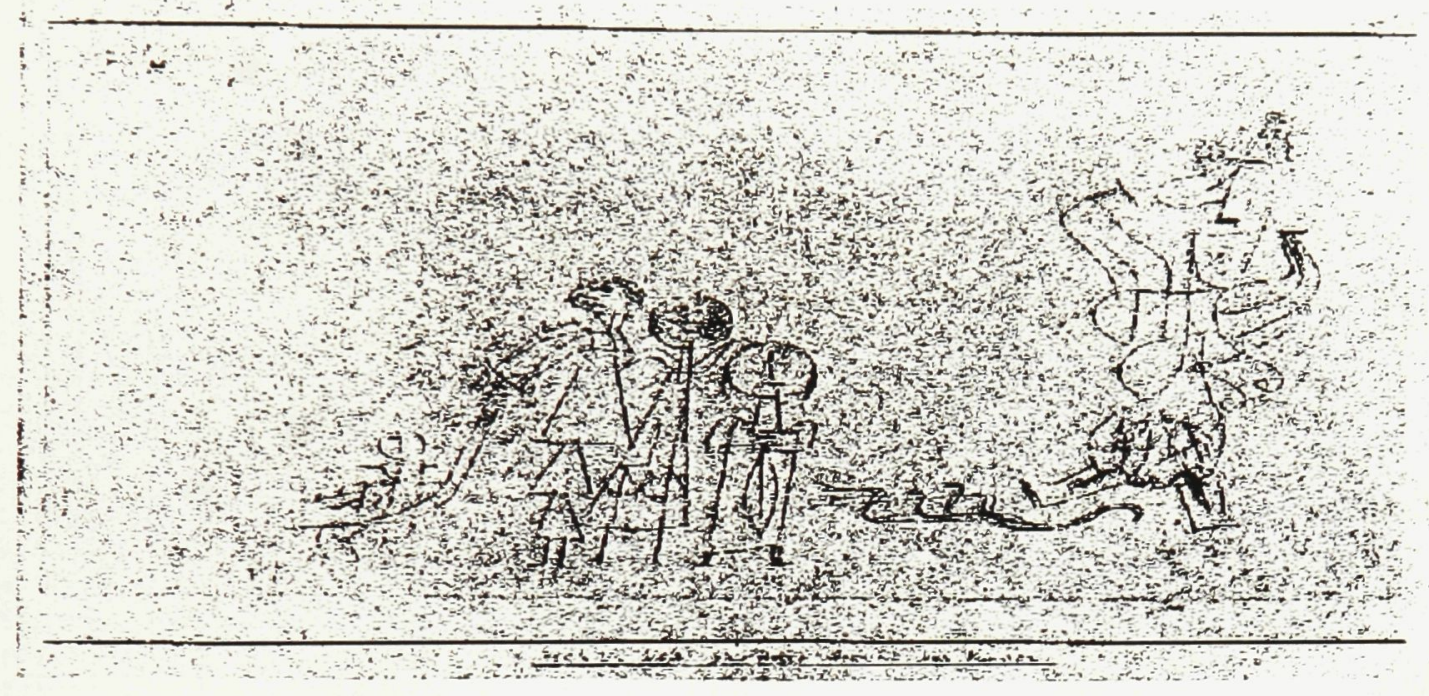

Figure 51

A Witch Threatens Four Children, 1922

Ink and pencil on paper on cardboard

$10.2 \times 23.8 \mathrm{~cm}$

Paul Klee-Stiftung, The Zentrum Paul Klee 


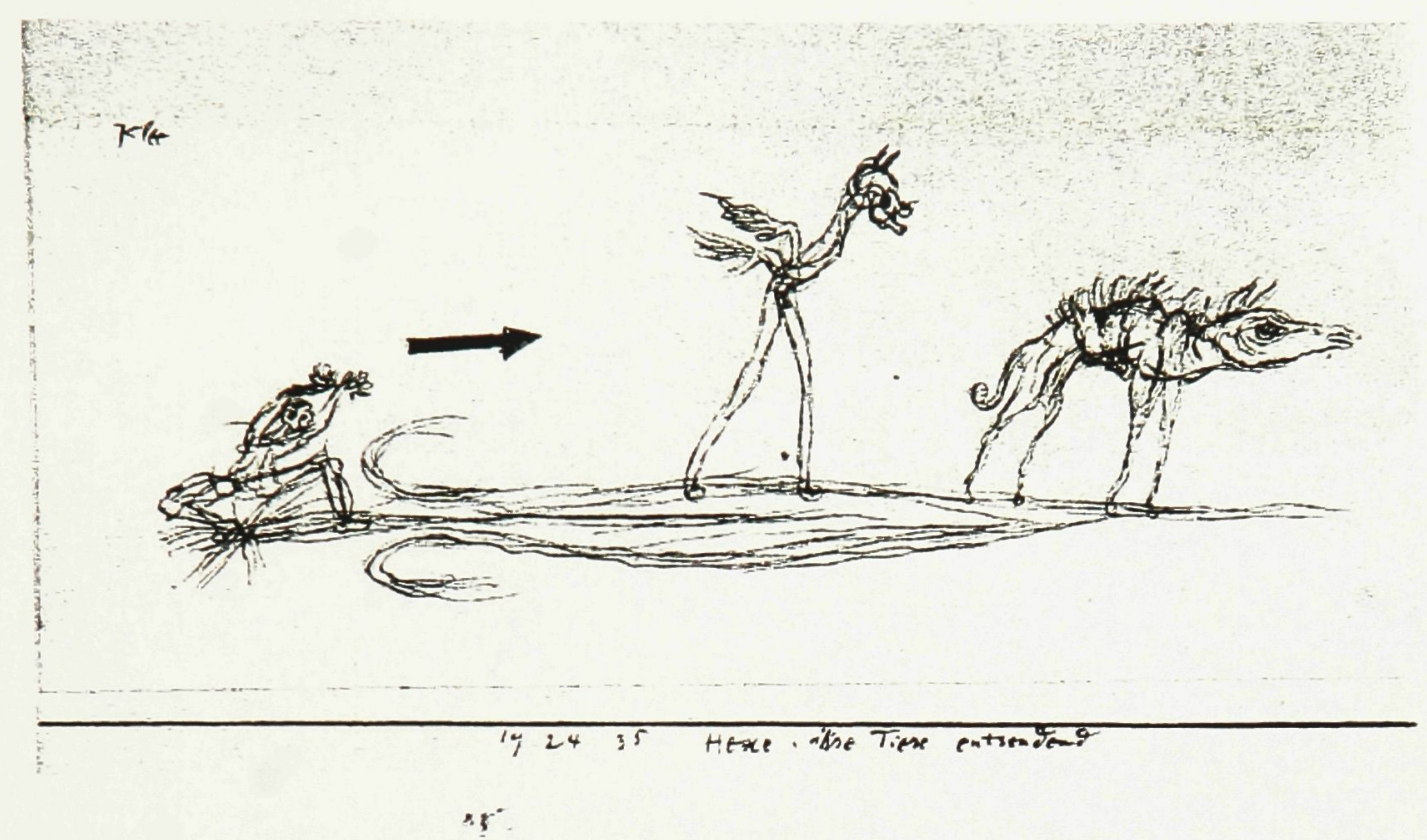

Figure 52

Witch, Dispatching Her Animals, 1924

Ink on paper on cardboard

$10.2 \times 23.8 \mathrm{~cm}$

San Francisco Museum of Modern Art

Collection of Carl Djerassi 


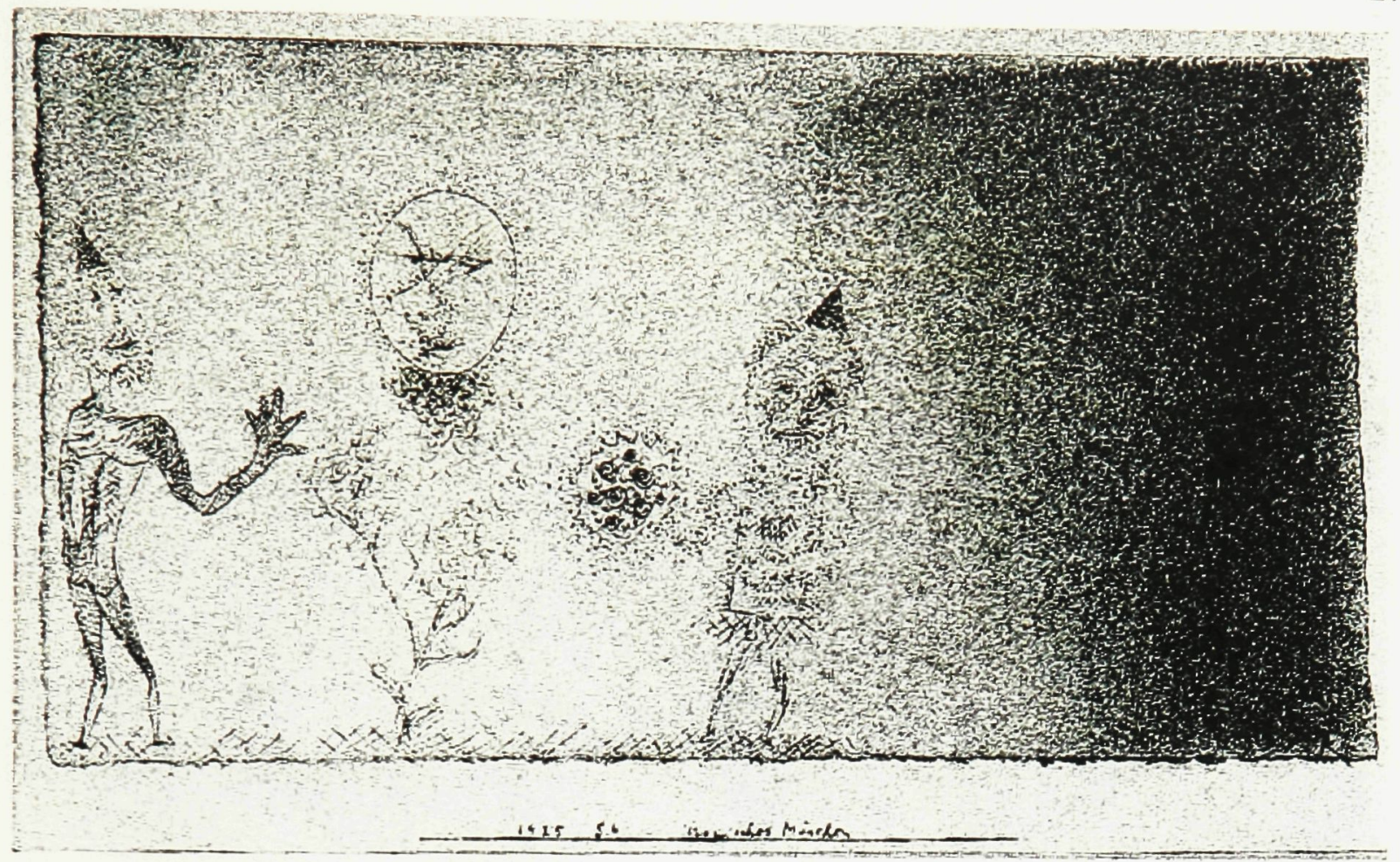

Figure 53

Ironic Fairy Tale, 1925

Ink and watercolour on paper on cardboard

$11.2 \times 22.4 \mathrm{~cm}$

Sammlung Rosengart, Luzern 


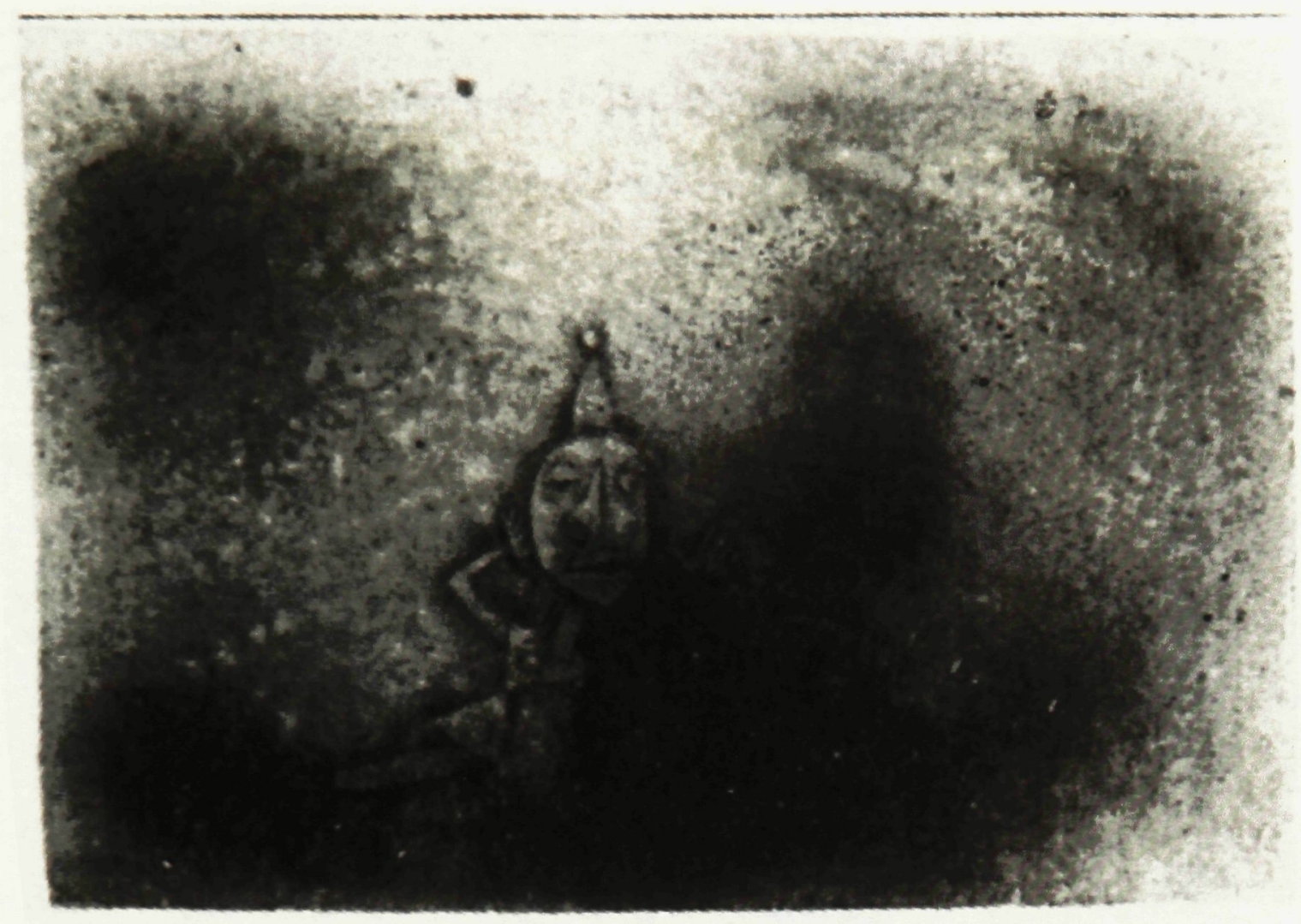

Figure 54

End of the Marionette, 1927

Ink and watercolour on paper on cardboard $32.5 \times 45.5 \mathrm{~cm}$

Location unknown 


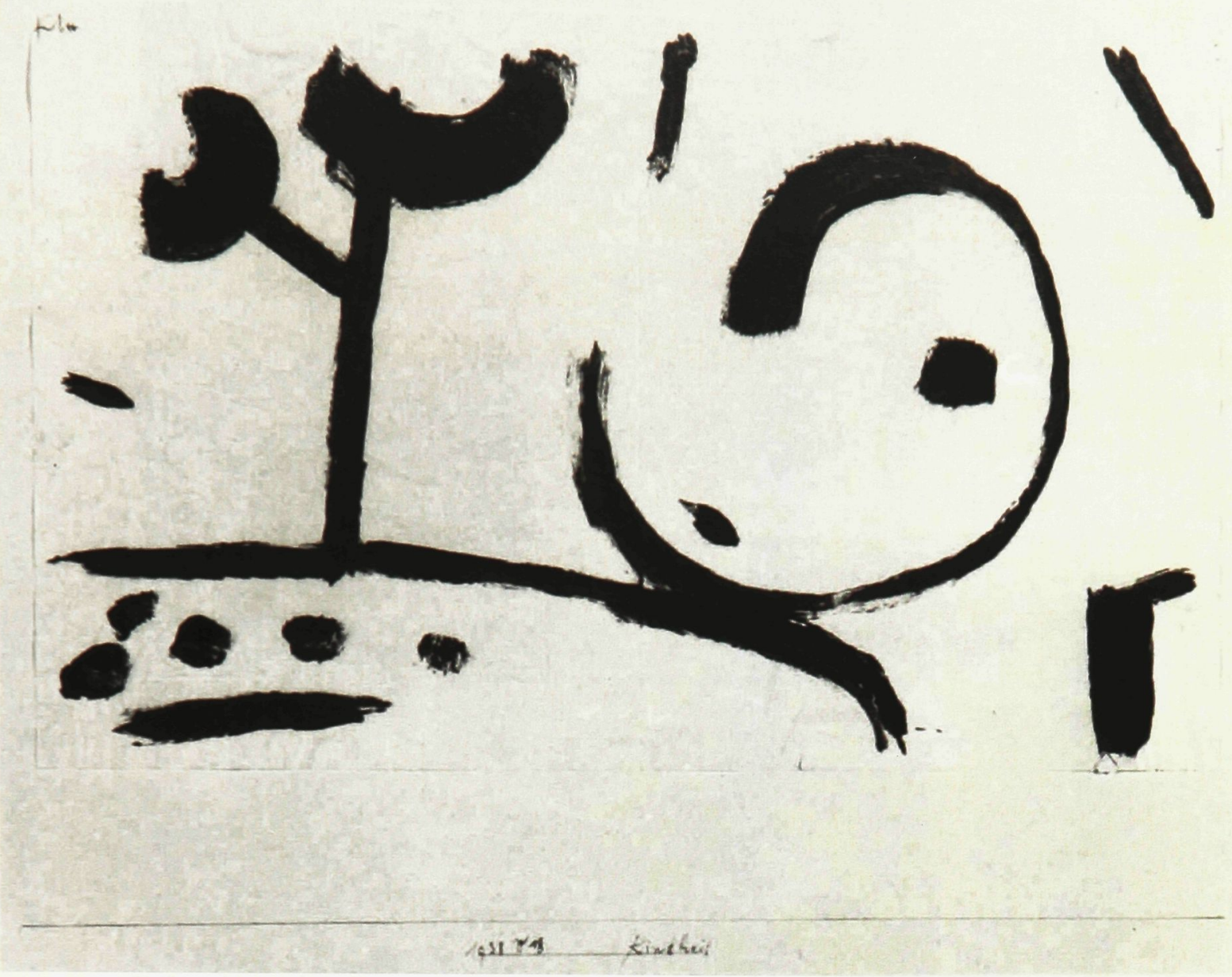

Figure 55

Childhood, 1938

Coloured paste on paper

$27 \times 42.8 \mathrm{~cm}$

Paul Klee-Stiftung, The Zentrum Paul Klee 


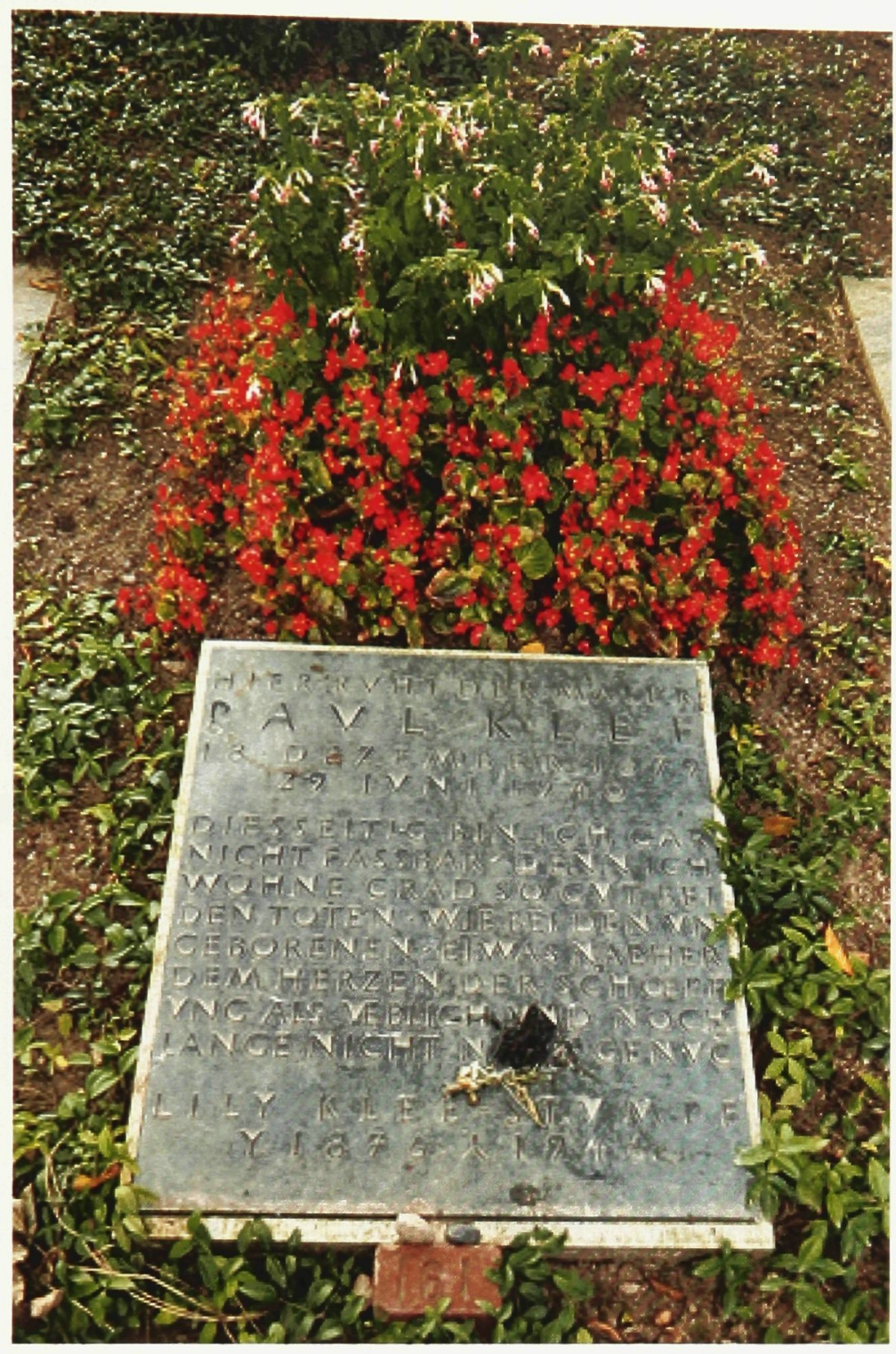

174

Figure 56

Photograph by the author, 2010

Paul Klee gravesite

Bern, Switzerland 


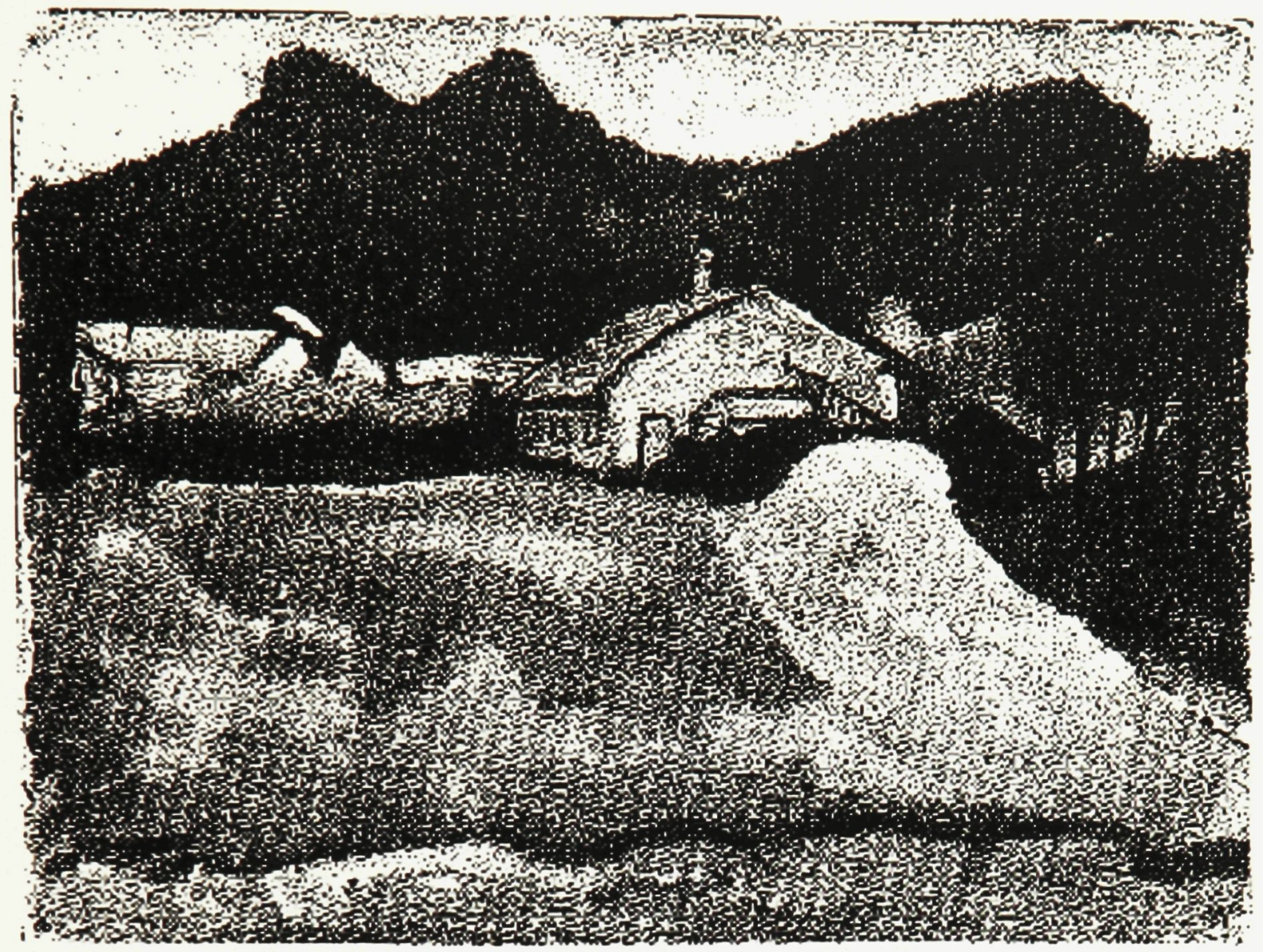

Figure 57

Untitled, 1905 (cat. rai. no. 230)

Oil paint on cardboard

$27.7 \times 37 \mathrm{~cm}$

The Art Museum, Princeton

Collection of John Maclean Magie and Gertrude Magie 


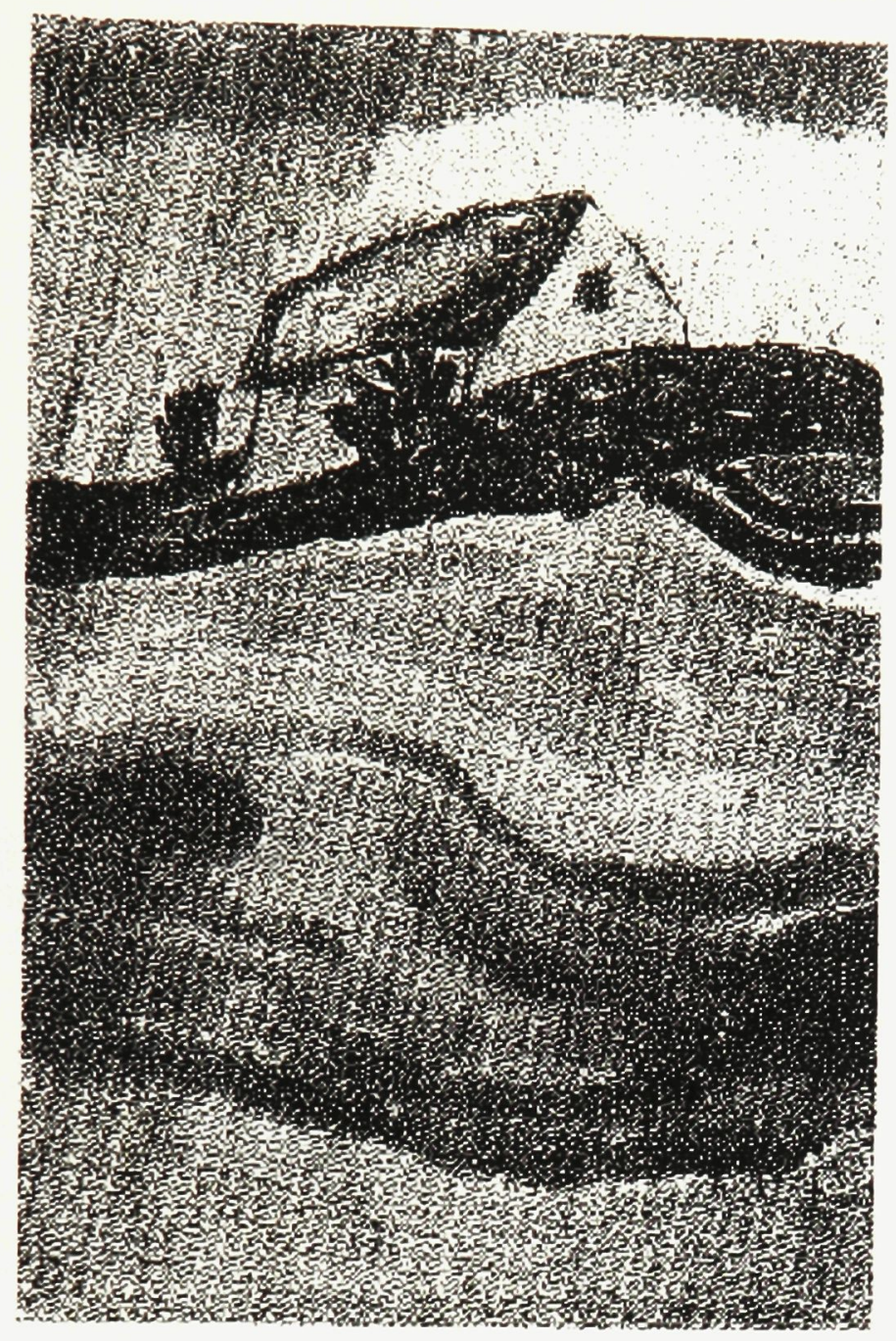

Figure 58

Untitled, 1905 (cat. rai. no. 231)

Oil paint on cardboard

$32 \times 21.5 \mathrm{~cm}$

Private Swiss collection 


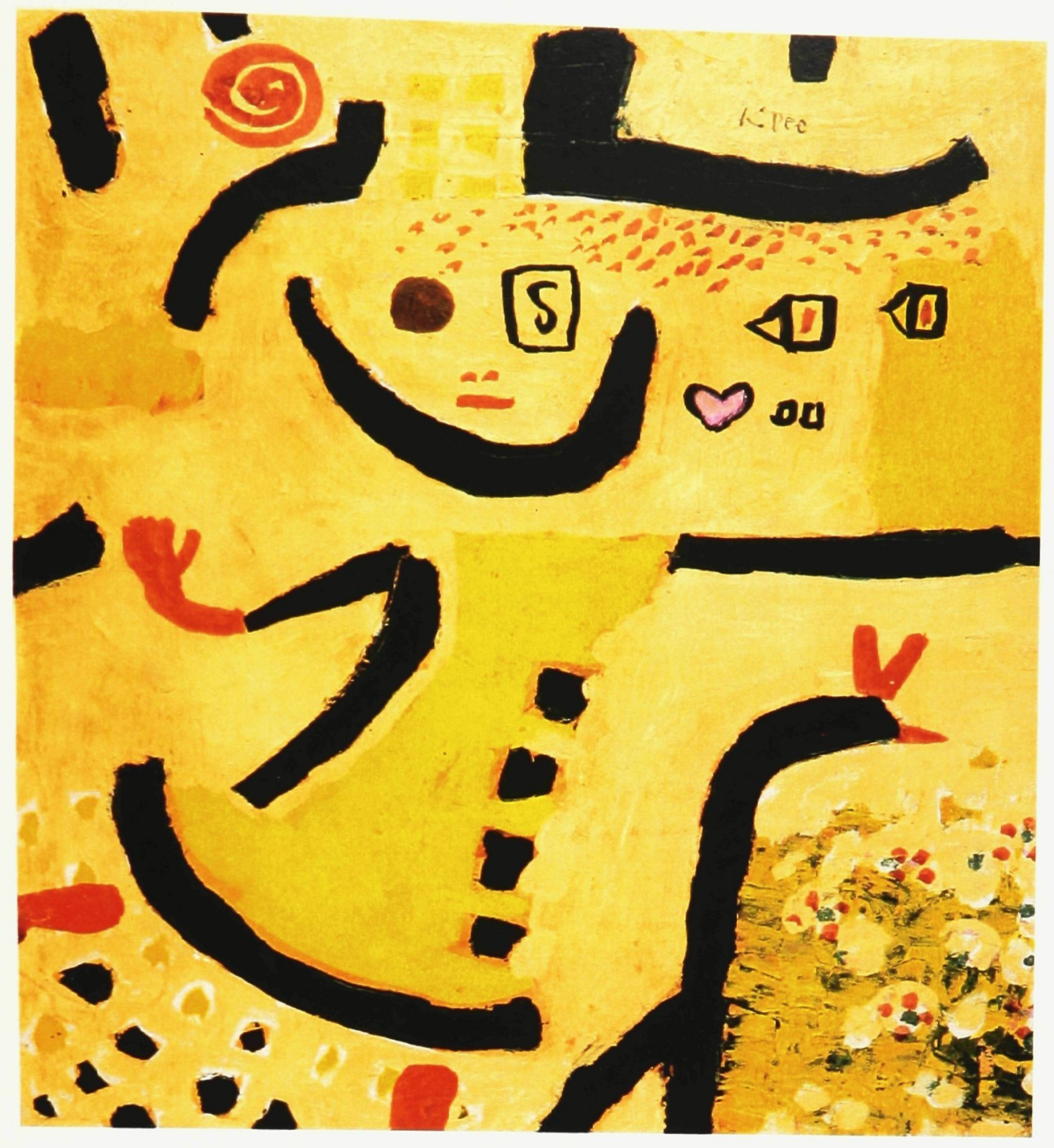

Figure 59

A Children's Game, 1939

Coloured paste and watercolour on cardboard

$43 \times 32 \mathrm{~cm}$

Die Sammlung Berggruen in den Staatlichen Museen zu Berlin 


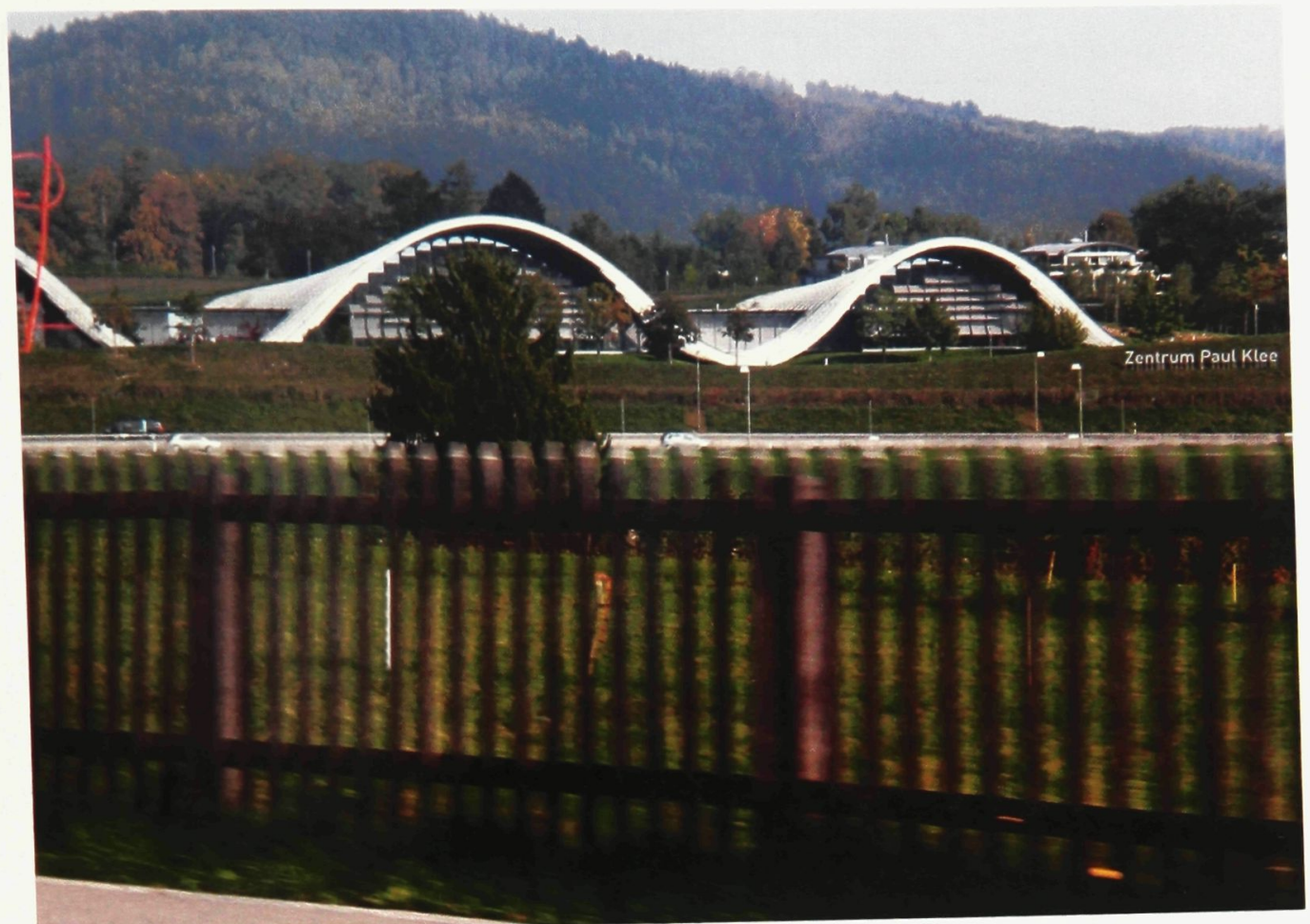

Figure 60

Photograph by the author, 2009

Zentrum Paul Klee

Bern, Switzerland 


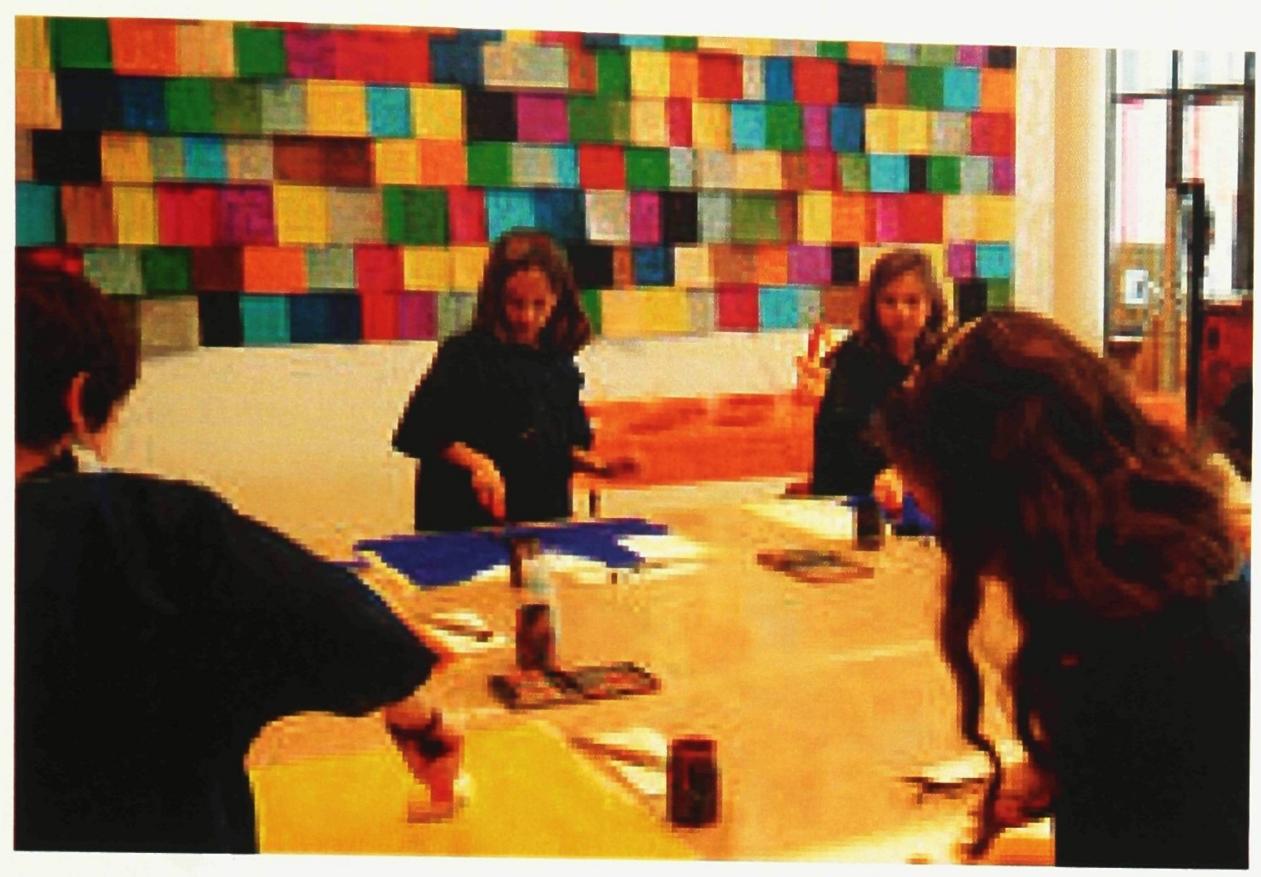

Figure 61

Children painting in the studio

Image from the website, www.creaviva-zpk.org

Kindermuseum Creaviva studio

The Zentrum Paul Klee

Bern, Switzerland 


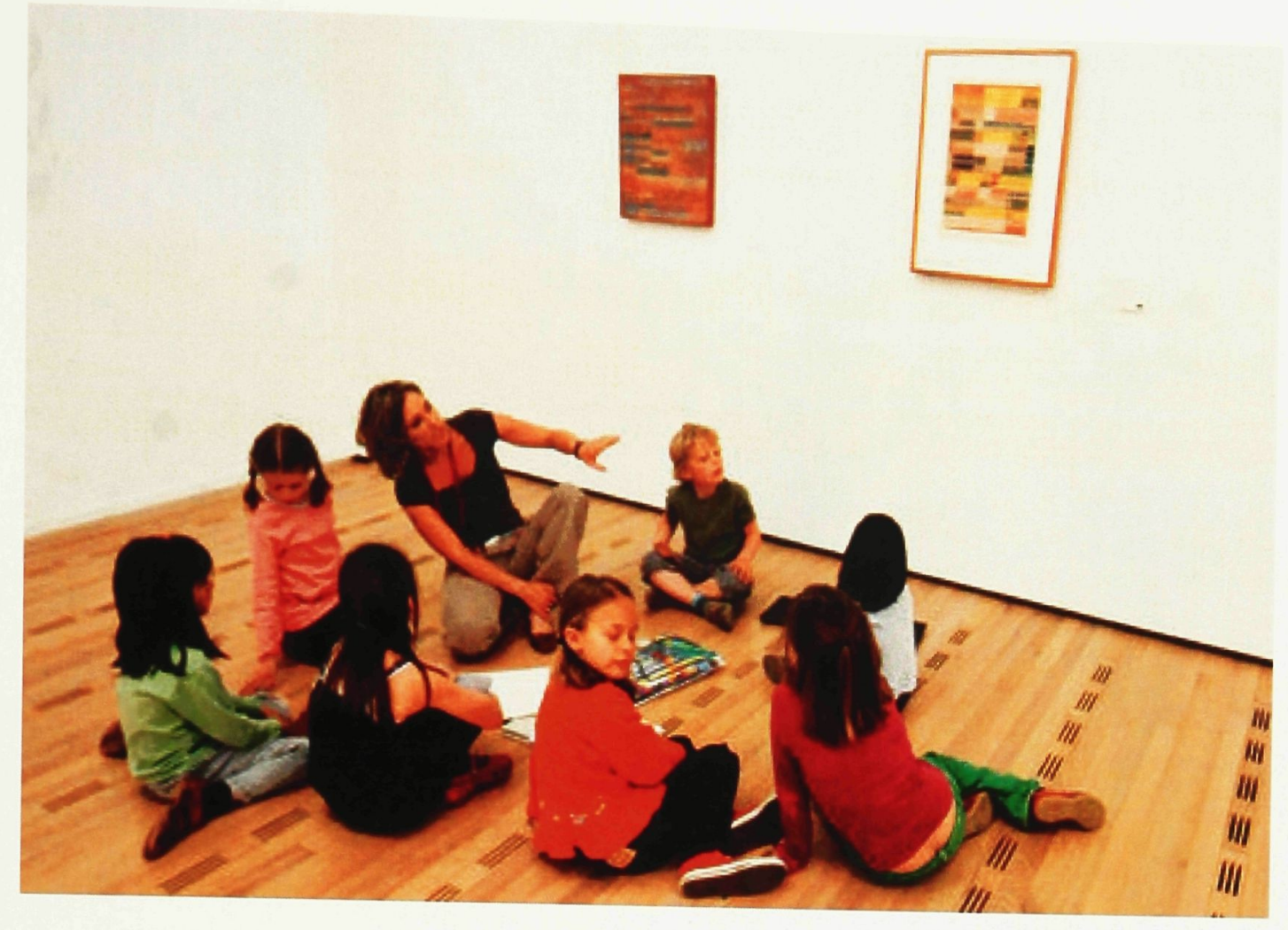

Figure 62

Children and their instructor in discussion of Klee's work Image from website, www.creaviva-zpk.org

Kindermuseum Creaviva studio

The Zentrum Paul Klee

Bern, Switzerland 


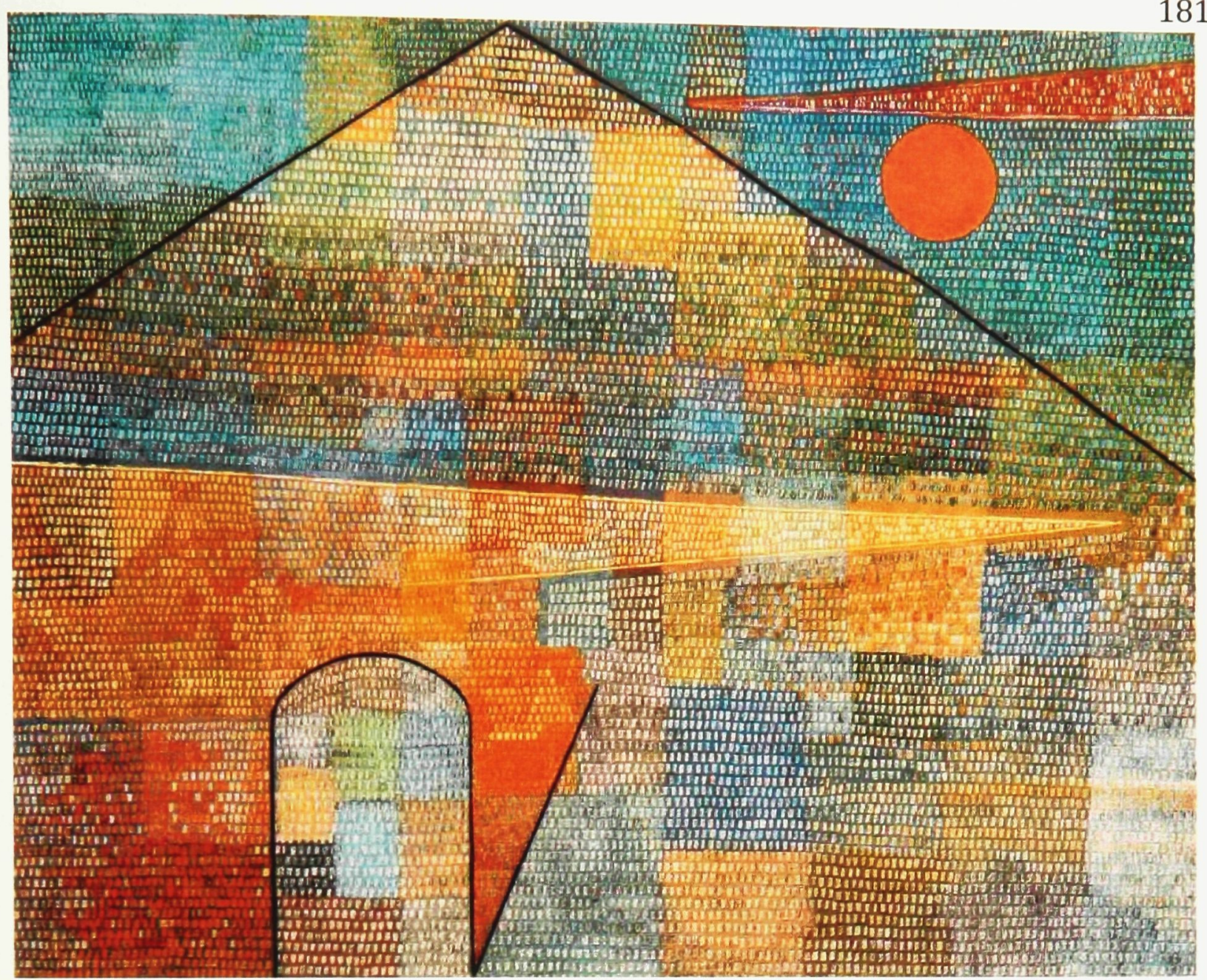

Figure 63

Ad Parnassum, 1932

Oil and casein colour on linen

$100 \times 126 \mathrm{~cm}$

Kunstmuseum, Bern 


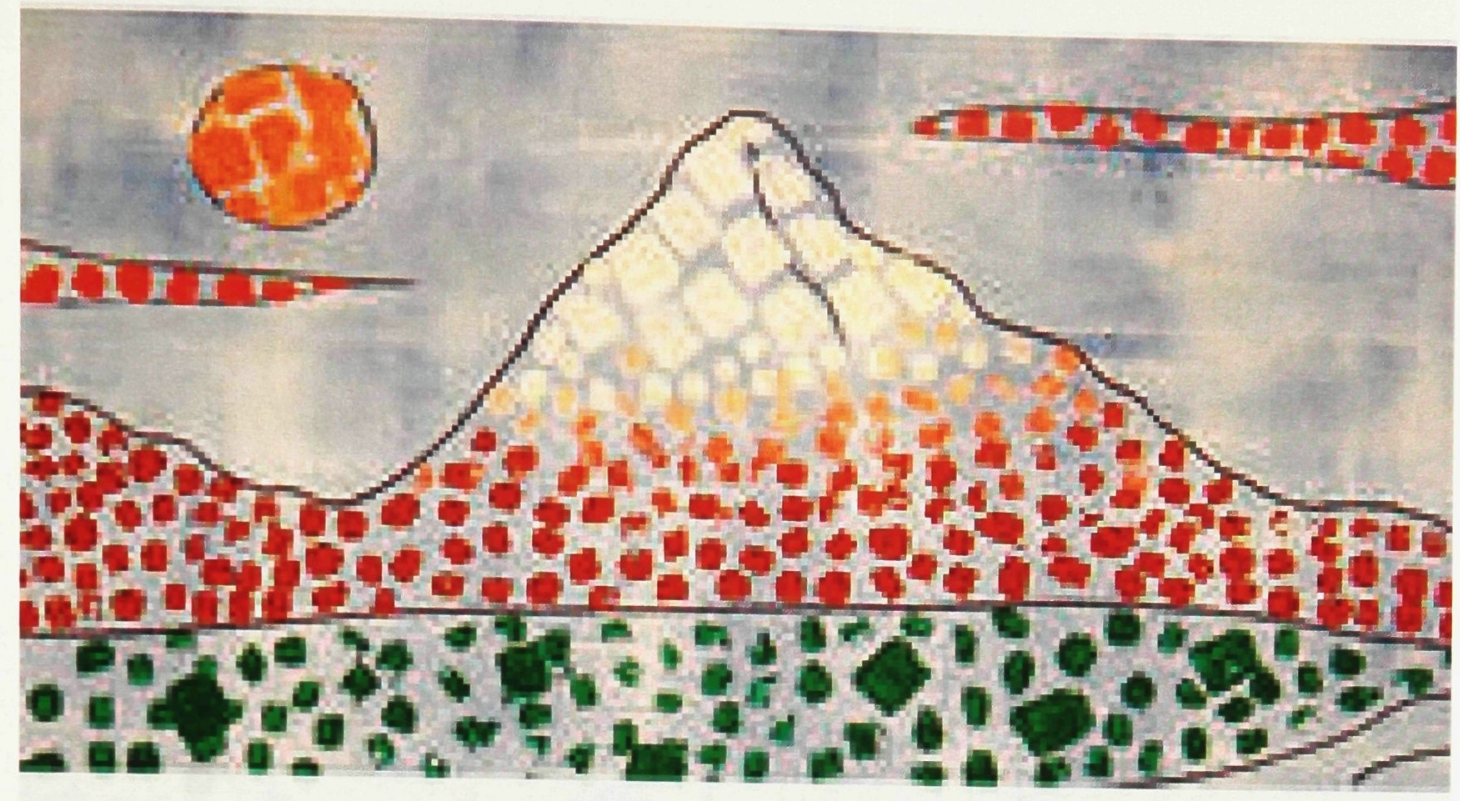

Figure 64

Child's painting

Image from website, www.creaviva-zpk.org

Kindermuseum Creaviva studio

The Zentrum Paul Klee

Bern, Switzerland 


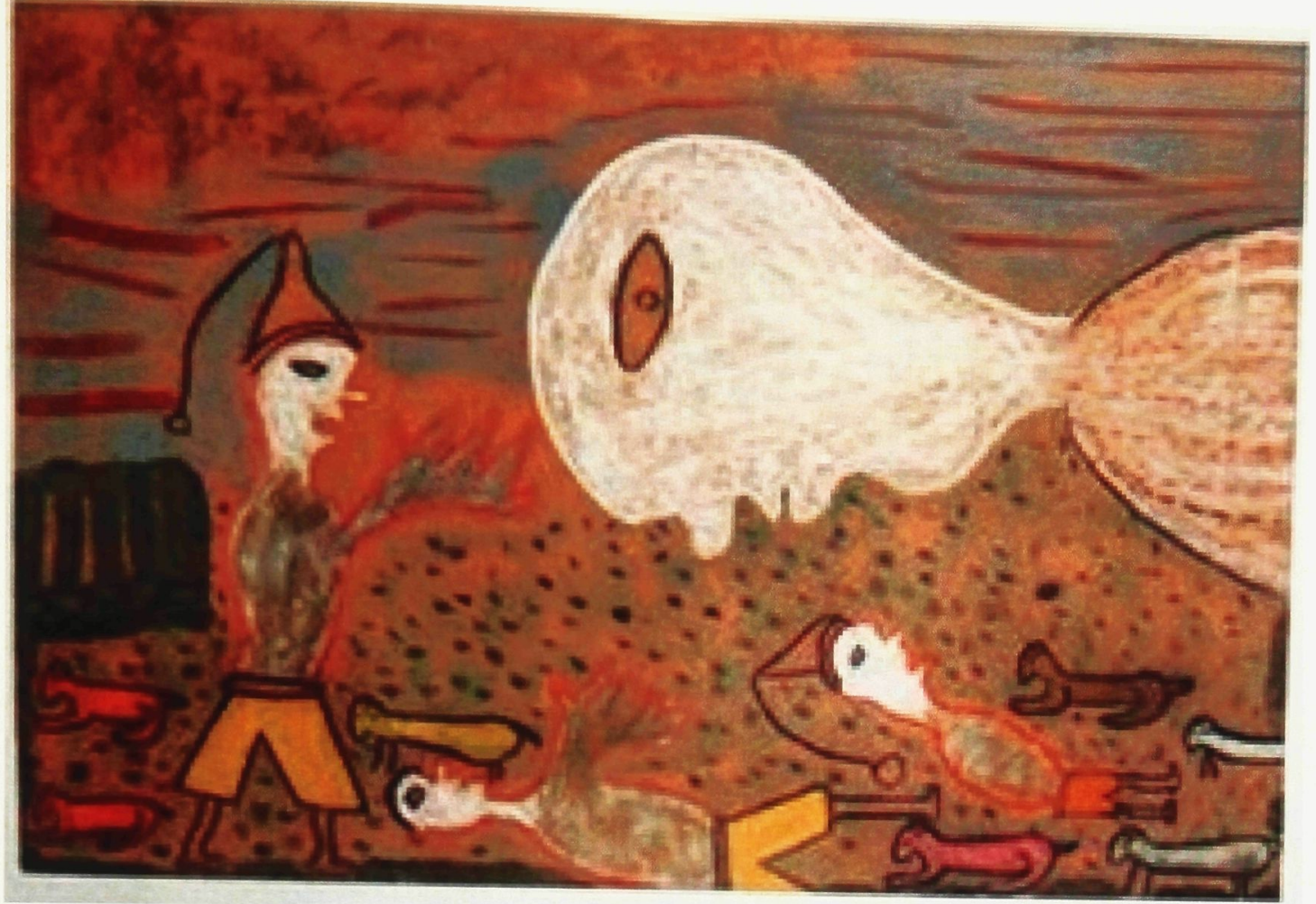

Figure 65

Child's drawing

Kindermuseum Creaviva studio

Image taken from the website, www.creaviva-zpk.org

Collection of Hans Hochreuter

The Zentrum Paul Klee

Bern, Switzerland 


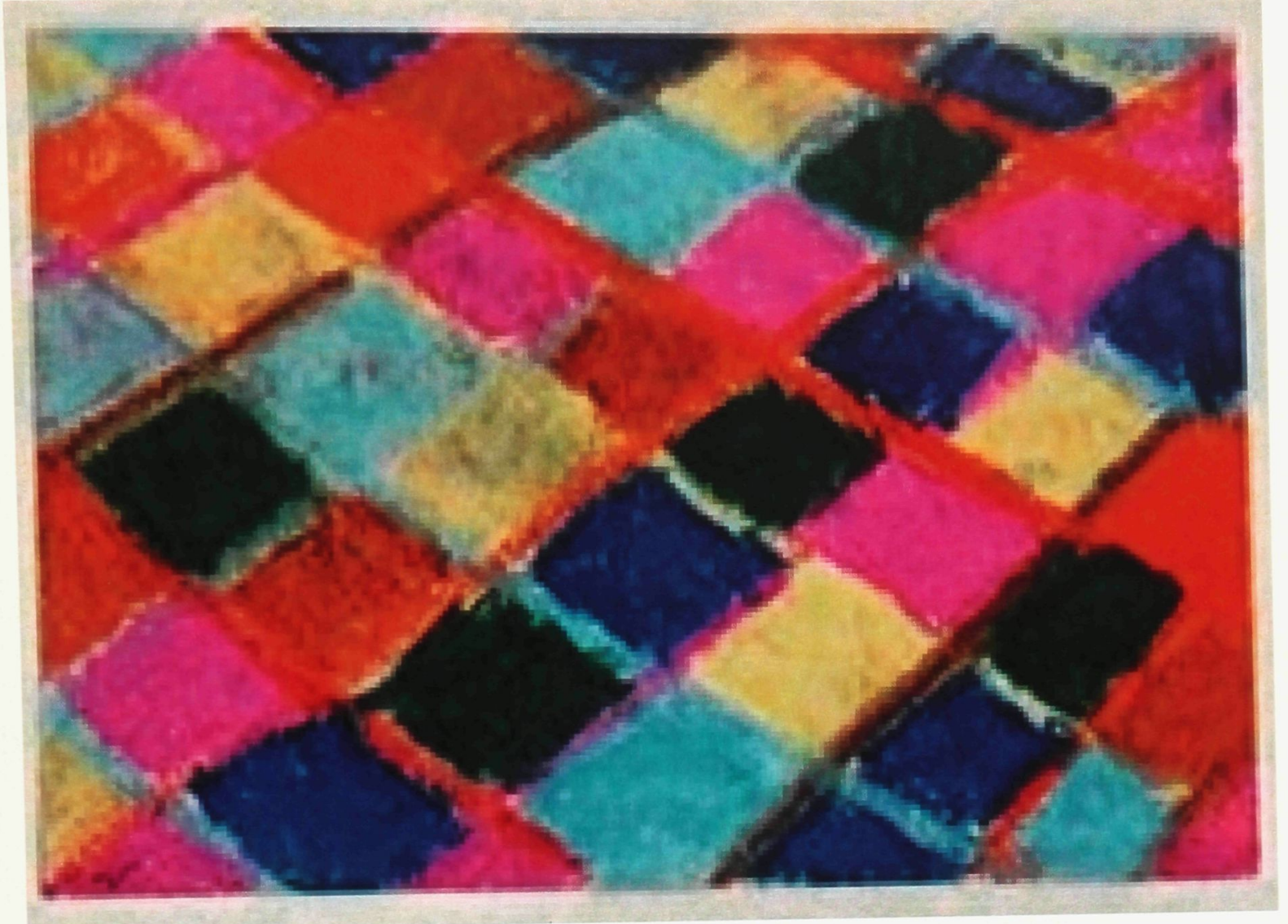

Figure 66

Child's drawing

Kindermuseum Creaviva

Image from website, www.creaviva-zpk.org

Collection of Hans Hochreuter

The Zentrum Paul Klee

Bern, Switzerland 


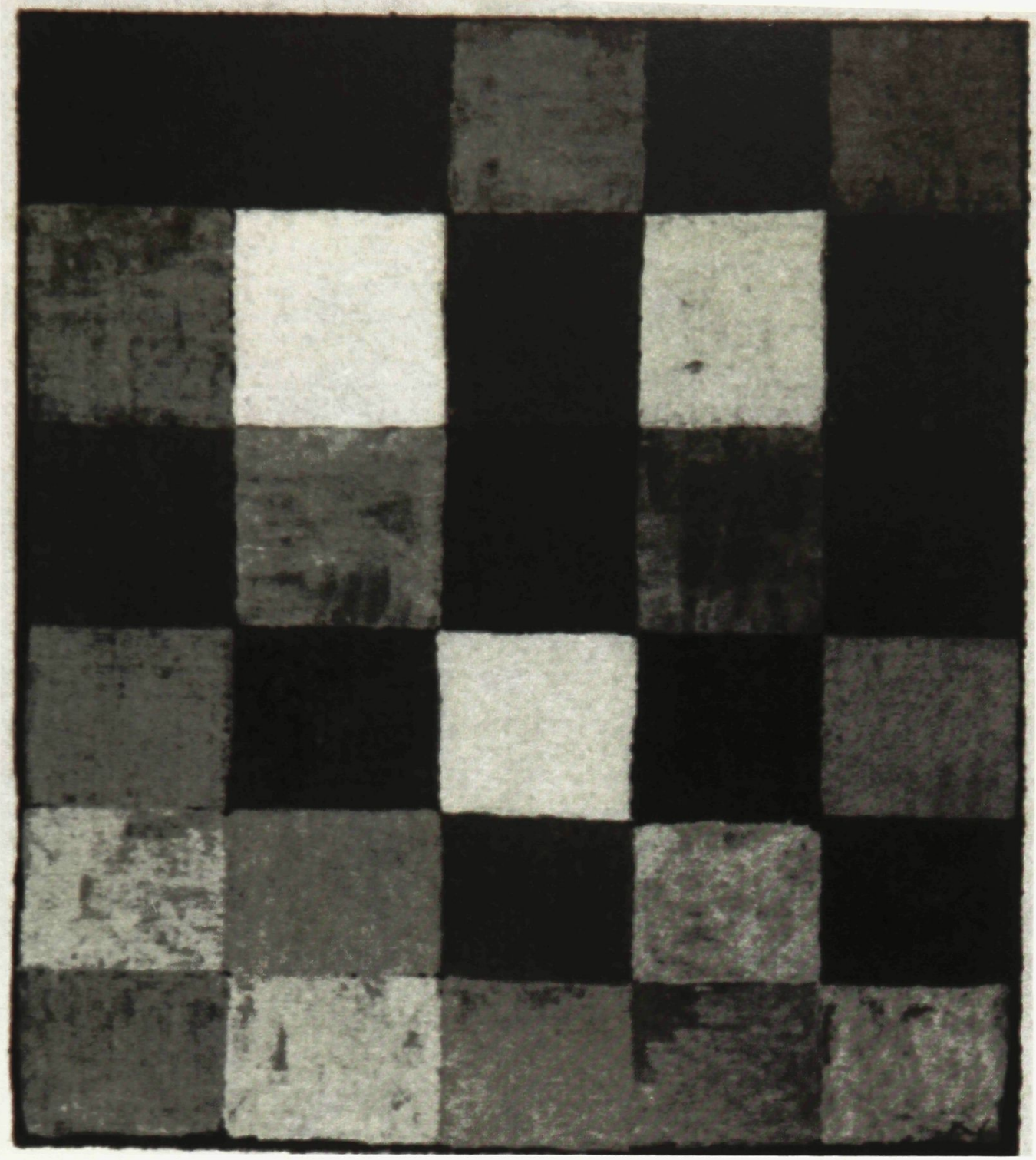

Figure 67

Colour Table (In Grey Major)

Oil pastel on paper on cardboard

37.7 x $30.4 \mathrm{~cm}$

Paul Klee-Stiftung, The Zentrum Paul Klee 


\section{Bibliography}

\section{$\underline{\text { Primary Sources }}$}

Apollinaire, Guillaume. Chroniques d'Art (1902-18). Edited by L.-C. Breunig (Paris: Gallimard, 1960).

---. Apollinaire on Art: Essays and Reviews, 1902-1918. Edited by L.-C. Breunig. Translated by Susan Suleiman. New York: Viking, Documents of $20^{\text {th }}$-Century Art, 1972.

Baldwin, James Mark. The Mental Development of the Child and the Race (1896). New York: Macmillan \& Co., 1906.

Chesterton, G. K. Orthodoxy. London: John Lane, 1909.

Däubler, Theodor. “Paul Klee,” Das Kunstblatt, no. 2 (1918): 24-27.

Delaunay, Robert. "La Lumiére.” Translated by Paul Klee. Der Sturm (Berlin) no. 144145 (January, 1913).

Dostoyevsky, Fyodor. "White Nights" (1848). In White Nights and Other Stories, edited by Susan L. Rattiner, 166-208. Mineola, New York: Dover Publications, Inc., 2008.

Eng, Helga. The Psychology of Children's Drawings. London: Kegan Paul, 1931.

Franklin, Benjamin. "Remarks Concerning the Savages of North America" (1784). In Health Anthology of American Literature, Fifth Edition. New York: Houghton Miflin, 2004.

Freud, Sigmund. Beyond the Pleasure Principle (1920). Translated by James Strachey. New York: Bantam Books, 1963.

---. "Fetishism" (1927) Miscellaneous Papers of 1888-1938. Collected Papers, Vol. 5. London: Hogarth and Institute of Psycho-Analysis, 1924-1950.

---. Studies in Hysteria II. Translated by James Strachey, 2nd Edition (1893). Hogarth Press, 1955.

---. Three Essays on the Theory of Sexuality (1905). Translated by James Strachey. New York: Basic Books, 1962.

---. Totem and Taboo: Some Points of Agreement Between the Mental Lives of Savages and Neurotics. Translated by James Strachey. London: Routledge and Kegan Paul, 1960. 
Fry, Roger. Vision and Design. London: Chatto and Windus, 1920.

Fux, Johann Joseph. Gradus ad Parnassum (1725). New York: Broude Brothers, 1966.

Gesell, Arnold. Wolf Child and Human Child. London: The Scientific Book Club, 1942.

Geist, Hans-Friedrich. “Kinder über Paul Klee.” Das Kunstblatt 14, no. 1 (1930): 21-26.

---. Paul Klee. Hamburg: Ernst Hauswedell, 1948.

---. “Paul Klee und die Welt des Kindes.” Werk 37, no. 6 (June 1950): 186-192.

Goethe, Johann Wolfgang von. The Fairy Tale of the Green Snake and the Beautiful Lily (1795). Translated by Donald Maclean. Grand Rapids, MI: Phanes Press, 1993.

---. Faust: A Tragedy. Leipzig: F. A. Brockhaus, Bayard Taylor, 1881.

Grimm, Jacob and Wilhelm. The Annotated Brothers' Grimm. Edited by Maria Tatar. New York: W.W. Norton and Co., 2004.

Grohmann, Will. "Paul Klee und die Tradition.” Bauhaus 3 (December 1931): 2-5.

Guénon, René. Theosophy: History of a Pseudo-Religion (1921). New York: Sophia Perennis, 2004.

Haeckel, E. Riddle of the Universe at the Close of the Nineteenth Century in Evolution in Modern Thought (1899). Translated by Joseph McCabe. New York: Prometheus Books, 1992.

Hall, Granville Stanley. "The Contents of Children's Minds on Entering School." Pedagogical Seminary 1 (1891): 139-173.

---. Adolescence: Its Psychology and Its Relations to Physiology, Anthropology, Sociology, Sex, Crime, Religion, and Education. New York: Appleton, 1904.

Hartlaub, Gustav Freidrich. "Der Genius im Kinde." Der Neue Merkur 5, no. 4 (1921/22): 292.

---. Der Genius im Kinde. Breslau: Hirt, 1922.

Hinz, Sigrid Edited. Caspar David Friedrich in Briefen und Bekenntnissen. Munich: Rogner and Bernard, 1968.

Hobbes, Thomas. Leviathan. Edited by Edwin Curley. Indianapolis/ Cambridge: 
Hackett Publishing Company, Inc.: 1994.

Hoffmann, Edith. Children in the Past. London: Collins Publishers: 1940.

Homer, The Odyssey. Edited by Robert Squillace. Translated by George Herbert Palmer.

New York: Barnes and Noble, 2003.

Hugo, Victor. "L'Art d'être grand-père" (1877). In Selected Poems of Victor Hugo, edited by Steven Monte. London: Routledge, 2002.

Humperdinck, Engelbert. Hansel and Gretel. Boca Raton: Kalmus Edition, 1985.

Kandinsky, Wassily. "Uber die Formfrage," in Der Blaue Reiter (1912), New Edition. Munich, 1965.

---. “Art Without Subject” (Stockholm, 1916). In Kandinsky: Complete Writings on Art, Vol. 1, edited by Kenneth C. Lindsay and Peter Vergo, 419-420. Boston, Mass.: G. K. Hall \& Co., 1982.

---. "On the Spiritual in Art” (1912). In Kandinsky: Complete Writings on Art, Vol. I, edited by Kenneth C. Lindsay and Peter Vergo, 119-219. Boston, Mass.: G. K. Hall \& Co., 1982.

Jung, Carl. The Collected Works of C.G Jung. Translated and Edited by G. Adler, R.F. Hull. Princeton: Princeton University Press, 1969.

Kant, Immanuel. Metaphysical Foundations of Natural Science. Translated by James Ellington. Indianapolis and New York: The Bobbs-Merrill Company, Inc., 1970.

---. Critique of Judgement. Translated by J.H. Bernard, 2nd Edition. London: Macmillan, 1914.

Kerschensteiner, Georg. Die Entwicklung der zeichnerischen Begabung (The Development of Drawing Ability). Munich: Gerber, 1905.

Key, Ellen. The Century of the Child (1909). New York: Arno Press and the New York Times, 1972.

Kirchner, E.-L. E. L. Kirchners Davoser Tagebuch. Edited by Lothar Grisebach. Cologne: Verlag M. DuMont Schaubert, 1968.

Kleist, Heinrich von. $\square$ "On the Puppet Theatre" (1811). In An Abyss Deep Enough: Letters of Heinrich von Kleist with a Selection of Essays and Anecdotes, edited and translated by Philip B. Miller. New York: E.P. Dutton, 1982.

Klee, Felix, ed. Paul Klee: His Life and Work and Documents, Selected from Posthumous 

Writings and Unpublished Letters. Translated by Richard and Clara Winston. New
York: Braziller, 1962.

Klee, Paul. The Diaries of Paul Klee: 1898-1918. Edited by Felix Klee. Los Angeles:

University of California Press, 1964.

---. Briefe an die Familie (1893-1906). Edited by Felix Klee. Cologne: Dumont, 1979.

---. "Creative Credo" (1920). In The Inward Vision, edited by Carola Giedion-Welcker, Will Grohmann, Werner Haftmann, Werner Schmalenbach, Georg Schmidt. Translated by Norbert Guterman. Cologne: Verlag M. DuMont, 1958.

---. On Modern Art. London: Faber and Faber, 1948.

---. Paul Klee: Pedagogical Sketchbook (1924). Introduced and Translated by Sibyl Moholy-Nagy. New York: Frederick A. Praeger, 1953.

---. Paul Klee: The Nature of Nature. The Notebooks, Vol. 2. Edited by Jürg Spiller. Translated by Ralph Mannheim. New York: George Wittenborn Inc., 1970.

---. Paul Klee: The Thinking Eye. The Notebooks, Vol. 1. Edited by Jürg Spiller. Translated by Ralph Mannheim. London: Lund Humphries, 1961.

---. Tagebücher $(1898$ - 1918). Edited by Wolfgang Kersten. Stuttgart: Verlag Gert Hatje; and Teufen: Verlag Arthur Niggli, 1988.

---. Schriften, Rezensionen und Aufsätze. Edited by Christian Geelhaar. Cologne: DuMont Buchverlag, 1976.

Levinstein, Siegfried. Kinderzeichnungen bis zum 14. Lebensjahr. Leipzig: R. Voigtlander, 1905.

Lichtwark, Alfred. "Die Kunst in der Schule," in Alfred Lichtwark: Eine Auswahl seiner Schriften, edited by Wolf Mannhardt. Berlin: Bruno Cassirer, 1917.

MacDonald, George. Phantastes: A Faerie Romance for Men and Women. London: Smith, Elder, and Co., 1858.

Masson, Andre. The Eulogy of Paul Klee. Translated by Walter Pach (1946). New York: Valentin, 1950.

Modersohn-Becker, Paula. The Letters and Journals. Edited by Gunter Busch and Liselotte von Reinken. Translated by Arthur S. Wensinger and Carol Clew Hoey. New York: Taplinger Pub. Co., 1983. 
Nolde, Emil. Jahre der Kämpfre. Berlin: Rembrandt-Verlag, 1934.

Oxenford, John, ed. Conversations of Goethe with Eckermann and Soret. London: George Bell \& Sons, York Street, 1874.

Piaget, Jean. The Language and Thought of the Child (1926). London: Routledge Classics, 1959.

---. The Child's Conception of the World (1929). London: Routledge \& Kegan and Paul Ltd., 1971.

Pissarro, Camile. Correspondence de Camille Pissarro, 1865-1885. Edited by Janine Baily-Herzberg. Paris: Presses Universitaires du France, 1980.

Rousseau, Jean-Jacques. Émile, or On Education. Translated by Allan Bloom. New York: Basic Books, 1979.

---. The Social Contract (1762). Edited by Paul Negri and Drew Silver. Mineola, N.Y.: Dover Publications, 2003.

Runge, Philipp Otto. Hinterlassene Schriften (1840). Edited by Johann Daniel Runge, Vol 1. Gottingen: Vandenhoeck \& Ruprecht, 1965.

Schiller, Friedrich von. "On Naive and Sentimental Poetry: Part 1" (1795). In Shorter Prose Writings. Translated by William F. Werts, Jr. Berlin: 1800.

http://www.schillerinsti

tute.org/transl/Schiller_essays/naive_sentimental-1.html.

---. On the Aesthetic Education of Man in a Series of Letters. Translated by Reginald Snell. London: Routledge and Kegan Paul Ltd., 1954.

Schmidt, Paul F. “Kinderzeichnungen.” Das Tagebuch 10, no. 47 (23 November 1929): 2003-2004.

Scholz, Robert. "Kunstgötzen stürzen,” Deutsche Kultur-Wacht, no. 10 (1933): 5.

Sully, James. Studies of Childhood. New York: D. Appleton and Co., 1896.

Teacher Combination for the Care of the Artistic Education: The Child as an Artist (handbook to the exhibition of the same name with an introduction text of Carl Götze). Hamburg: Kunsthalle zu Hamburg, 1898.

Van Gogh, Vincent. Complete Letters of Vincent Van Gogh, Vol. I. Boston; New York; London: Bulfinch Press, 2000. 
Wordsworth, William. "My heart leaps up when I behold" (1807). In The Oxford Authors: William Wordsworth, edited by Stephen Gill. Oxford and New York:

Oxford University Press, 1984.

---. "The Sublime and the Beautiful” (1798). In William Wordsworth: Selected Prose, edited by John O. Hayden, 264-267. London: Penguin Books, 1988.

Zola, Émile. L'oeuvre. Paris: G. Charpentier et C. Éditeurs, 1886.

\section{$\underline{\text { Secondary Sources }}$}

Aichele, K. Porter. Paul Klee, Poet/Painter. New York: Camden House, 2006.

Anger, Jenny. Paul Klee and the Decorative in Modern Art. Cambridge: Cambridge University Press, 2004.

Arheim, Rudolf. Art and Visual Perception. Berkeley: University of California Press, 1954.

Ariès, Philippe. Centuries of Childhood: A Social History of Family Life. Translated by Robert Baldick. New York: Alfred A. Knopf, 1962.

Barasch, Moshb. Theories of Art From Plato to Winckelmann. New York: New York University Press, 1985.

Battist, Sondra. "Child Art and Visual Perception." Art Education 20, no. 1 (1967): 2127.

Baudelaire, Charles. "The Painter of Modern Life." In Baudelaire: Selected Writings on Art and Literature, translated by P.E. Charvet, 395-422. New York: Viking Press, 1972.

Baumgartner, Michael. “'Reducing the Contingent to its Essence': Paul Klee's Dialogue with Nature." In Paul Klee's Enchanted Garden, edited by Zentrum Paul Klee, 2445. Bern: Hatje Cantz, 2008.

Bennett, Tony. The Birth of the Museum: History, Theory, Politics. New York: Routledge, 1995.

Benzaquén, Adrianna S. Encounters with Wild Children. London, Ithaca, Montreal and Kingston: McGill-Queen's University Press, 2002.

Bernheimer, Richard. Wild Men in the Middle Ages. Cambridge: Harvard University 
Press, 1952.

Berry, K. "Young's relativism, Kant, and Kandinsky." Journal of Aesthetic Education 32, no. 1 (Spring 1998): 92-96.

Bettleheim, Bruno. The Uses of Enchantment: The Meaning and Importance of Fairy Tales. New York: Knopf, 1976.

Bihalji-Merin, Oto. Modern Primitives: Masters of Naïve Painting. Translated by Norbert Guterman. London: Thames and Hudson, 1959.

---. Modern Primitives: Naïve Painting from the Late Seventeenth Century Until the Present Day. Translated by Russell M. Stockman. London: Thames and Hudson, 1971.

Bisanz, Rudolf M. German Romanticism and Philipp Otto Runge: A Study in NineteenthCentury Art Theory and Iconography. DeKalb: Northern Illinois University Press, 1970.

Blind, Karl. "Wodan, the Wild Huntsman, and the Wandering Jew." In The Wandering Jew: Essays in the Interpretation of a Christian Legend, edited by Galit HasanRokem and Alan Dundes, 169-189. Bloomington: Indiana University Press, 1986.

Blotkamp, Carel. The Art of Destruction. London: Reaktion Books Ltd., 1991.

Bluebond-Langner, Myra and Jill E. Korbin. "Challenges and Opportunities in Anthropology of Childhoods: An Introduction to 'Children, Childhoods, and Childhood Studies."” American Anthropologist 109, no. 2 (June, 2007): 241-246.

Blumenthal, Eileen. Puppetry: A World History. New York: Harry N. Abrams, Inc., 2005.

Boas, George. The Cult of Childhood. London: University of London, 1966.

Borchardt-Hume, Achim. Albers and Moholy-Nagy: From the Bauhaus to the New World. London: Tate Modern, 2006.

Bowlt, John E. "Esoteric Culture and Russian Society." In The Spiritual in Art: Abstract Painting 1890-1985, edited by Maurice Tuchman, 165-183. New York: Abbeville Press, 1986.

Brasch, R. The Star of David. London and Sydney: Angus and Robertson, 1965.

Brandenburg, Birgit. Paul Klee für Kinder: Eine Werkstatt. Mülheim an der Ruhr: Verl an der Ruhr, 2002. 
Brown, Marilyn R. Picturing Children: Constructions of Children Between Rousseau and Freud. Aldershot: Ashgate, 2002.

Brüschweiler J., and G. Magnaguagno. Ferdinand Hodler. Zürich: Kunsthaus Zürich, 1983.

Buchan, Mark "Food for Thought: Achilles and the Cyclops." In Eating their Words: Cannibalism and the Boundaries of Cultural Identity, edited by Kristen Guest, 1134. Albany: State University of New York, 2001.

Burnett, David. Hommage A Paul Klee: 1879 - 1940. Ottawa: National Gallery of Canada, 1979.

Byrne, Lorraine. Schubert's Goethe Settings. Aldershot, U.K.: Ashgate Publishing Limited, 2003.

Carroll, Lewis. Alice's Adventures in Wonderland. New York: Sterling Publishing Co., 2004.

Chanan, Gabriel and Hazel Francis. Toys and Games of Children of the World. Paris: UNESCO, 1984.

Connolly, Sean. The Life and Work of Paul Klee. Oxford: Heinemann First Library, 2000.

---. Take-Off! The Life and Work of Paul Klee. Oxford: Heinemann Library Hardbacks, 2002.

Coveney, Peter. The Image of Childhood. Hammondsworth: Penguin, 1967.

Cox, Roger. Shaping Childhood: Themes of Uncertainty in the History of AdultRelationships. London: Routledge, 1996.

Cranston, Maurice. The Noble Savage: Jean-Jacques Rousseau 1754-1762. Chicago: University of Chicago Press, 1991.

Craw, Janita and Robert Leonard. "Inventing Childhood.” In Mixed Up Childhood, edited by Janita Craw and Robert Leonard, 128-167. New Zealand: Auckland Art Gallery, 2005.

Cross, Gary. The Cute and the Cool: Wondrous Innocence and Modern American Children's Culture. Oxford: Oxford University Press, 2004.

Currell, David. The Complete Book of Puppet Theatre. London: A \& C Black Ltd., 1976. 
Das Neue Testament. Motiv von Paul Klee. Katholisches Bibelwerk, 1998.

Deal, Lisa W., Deanna S. Gomby, Lorraine Zippiroli and Richard E. Behrman. "Unintentional Injuries in Childhood: Analysis and Recommendations." The Future of Children 10, no. 1 (Spring - Summer, 2000): 4-22.

Diehl, Gaston. Henri Matisse. Paris: Piere Tisné, 1954.

Doschka, Roland, ed. Paul Klee: Selected by Genius. London: Prestel, 2007.

Douglas, Charlotte. "Beyond Reason: Malevich, Matiushin and Their Circles." In The Spiritual in Art: Abstract Painting 1890-1985, edited by Maurice Tuchman, 184199. New York: Abbeville Press, 1986.

Düchting, Hugo. Paul Klee: Painting Music. Munich: Prestel, 1997.

Elderfield, John. Henri Mattisse: A Retrospective. New York: Museum of Modern Art and Thames and Hudson, 1992.

Falk, John Howard and Lynn Diane Dierking. The Museum Experience. Washington, D.C.: Whalesback Books of Howells House, 1992.

Fass, Paula S., ed. Encyclopedia of Children and Childhood in History and Society. New York: Macmillan Reference USA, 2004.

Fineberg, Jonathan, ed. Discovering Child Art: Essays on Childhood, Primitivism and Modernism. Princeton: Princeton University Press, 1998.

---. The Innocent Eye: Children's Art and the Modern Artist. Princeton: Princeton University Press, 1997.

---. Mit dem Auge des Kindes. Munich and Bern: Verlag Gerd Hatje, 1995.

---. When We Were Young: New Perspectives on the Art of the Child. California: Princeton University Press, 2006.

Fischer, Matthias. Der junge Hodler. Eine Künstlerkarriere 1872-1897. Wädenswil: Nimbus, 2009.

Flam, Jack. Matisse: The Man and His Art, 1869-1918. Ithaca and London: Cornell University Press, 1986.

Flinn, Michael W. The European Demographic System: 1500-1820. Baltimore: The Johns-Hopkins University Press, 1981. 
Floud, Roderick and Kenneth W. Wachter, "Poverty and Physical Stature: Evidence on the Standard of Living of London Boys 1770-1870." Social Science History 6 (1982):
422-52.

Franciscono, Marcel. "Paul Klee and Children's Art.” In Discovering Child Art: Essays on Childhood, Primitivism, and Modernism, edited by Jonathan Fineberg, 95-121. Princeton: Princeton University Press, 1998.

---. "Paul Klee's Lithographic Drawings of 1912: Some Unsuspected Illustrations of 'Faust"' Pantheon 41, no. 1 (January - March, 1983): 34 - 38.

---. Paul Klee: His Work and Thought. Chicago: University of Chicago Press, 1991.

---. Walter Gropius and the Creation of the Bauhaus in Weimar. Champaign: University of Illinois Press, 1971.

Frank, Mitchell and Erika Dolphin. Central European Drawings from the National Gallery of Canada. Catalogue of an Exhibition. Ottawa: National Gallery of Canada, 2007.

---. German Romantic Painting Redefined: Nazarene Tradition and the Narratives of Romanticism. Aldershot: Ashgate Press, 2001.

Formanek-Brunell, Miriam. Made to Play House: Dolls and the Commercialization of American Girlhood. New Haven: Yale University Press, 1993.

Galbraith, Gretchen R. Reading Lives: Reconstructing Childhood, Books, and Schools in Britain, 1870-1920. New York: St. Martin's Press, 1997.

Gamwell, Lynn. Exploring the Invisible: Art, Science, and the Spiritual. Princeton and Oxford: Princeton University Press, 2002.

Geelhaar, Christian. Paul Klee and the Bauhaus. New York: New York Graphic Society Ltd., 1973.

Gisbourne, Mark, Robert Kudielka, and Carl Djerassi. Paul Klee: Adult Memories of Childhood. Barcelona: La Caixa de Pensiones, 2007.

Giroux, Henry A. "Stealing Innocence: The Politics of Child Beauty Pageants.” In The Children's Culture Reader, edited by Henry Jenkins, 265-282. New York and London: New York University Press, 1998.

Glaesemer, J. ed. Paul Klee. Das Graphische und Plastische Werk. Bern: Paul-KleeStiftung, 1975. 
Goldwater, Robert. Primitivism in Modern Art. New York: Vintage Books, 1967.

Grohmann, Will. E.-L. Kirchner. New York: Arts Inc., 1961.

---. Paul Klee: 1879-1940 (1954). New York: Harry N. Abrams Inc., 1960.

Haftmann, Werner. The Mind and Work of Paul Klee. New York: Praeger, 1954.

Hall, Douglas. Paul Klee: The Last Years. London: The Arts Council of Great Britain, 1974.

Harvey, John H. Perspectives on Loss and Trauma: Assaults on the Self. Thousand Oaks, Calif.: Sage Publications, 2002.

Hedges, Lawrence E. Remembering, Repeating, and Working Through Childhood Trauma. London: Jason Aronson Inc., 1994.

Helfenstein, Josef. “The Issue of Childhood in Klee's Late Work.” In Discovering Child Art: Essays on Childhood, Primitivism, and Modernism, edited by Jonathan Fineberg, 122-156. Princeton: Princeton University Press, 1998.

Heyward, Colin. Growing up in France. Cambridge: Cambridge University Press, 2007.

---. A History of Childhood. Cambridge: Polity Press and Blackwell Publishing, 2001.

Higonnet, Anne. "What Do You Want to Know About Children?" In Picturing Children: Constructions of Childhood between Rousseau and Freud, edited by Marilyn R. Brown, 200-207. Burlington: Ashgate Publishing, 2003.

---. Pictures of Innocence: The History and Crisis of Ideal Childhood. New York: Thames and Hudson, 1998.

Hirsh, Sharon L. Hodler's Symbolist Themes. Ann Arbor, Michigan: UMI Research Press, 1983.

Hoffert, Sylvia D. Private Matters: American Attitudes toward Childbearing and Infant Nurture in the Urban North. 1800-1860. Urbana: University of Illinois Press, 1989.

Hopfengart, Christine. Der Blaue Reiter. Kunsthalle Bremen: Dumont, 2000.

---. Klee vom sonderfall zum Publikmsliebling. Mainz am Rhein: Verlag Phillipp von Zabern, 1989.

Hoppe-Sailer, Richard. "Genesis and Garden: The Case of 'Inferner Park." In Paul Klee's Enchanted Garden, 66 - 81. Bern: Zentrum Paul Klee and Hatje Cantz, 
2008.

James, Allison and Alan Prout, eds. Constructing and Reconstructing Childhood: Contemporary Issues in the Sociological Study of Childhood. London: Falmer
Press, 1990.

James, Allison, Chris Jenks and Alan Proust. Theorizing Childhood. Cambridge: Polity,
1998.

Jenks, Chris. Childhood. London: Routledge, 1996.

Jong, Joop de, ed. Trauma, War, and Violence: Public Mental Health in Socio-Cultural Context. New York: Kluwer Academic/Plenum Publishers, 2002.

Kagan, Andrew. Paul Klee and Music. Ithaca, New York: Cornell University Press, 1983.

---. “Paul Klee's Ad Parnassum: The Theory and Practice of Eighteenth-Century Polyphony as Models for Klee's Art.” Arts Magazine 2 (September, 1977): 90-104.

Kaplan, Frances. Art Therapy and Social Action. London: Jessica Kingsley Publishers, 2007.

King, Robert A., Peter B. Neubauer, Samuel Abrams, and A. Scott Dowling, ed. The Psychoanalytic Study of the Child, Vol. 62. New Haven: Yale University Press, 2007.

Klee, Felix. Maler des Expressionismus im Briefwechsel mit Eberhard Grisebach. Edited by Lothar Grisebach. Hamburg: Christian Wegner Verlag, 1962.

---. “Erinnerungen an meinen Vater." In Paul Klee, Catalogue of an Exhibition, Staaliche Kunstsammlungen. Dresden: Albertinum/Kupferstich-Kabinett, 1984.

Kleine, Gisela. Gabriele Münter und die Kinderwelt. Frankfurt/Main: Insel Verlag, 1997.

Klingsöhr-Leroy, Cathrin. Paul Klee in der Pinakothek der Moderne. Munich: Hatje Cantz Verlag, 1999.

Krippner, Stanley and Teresa M. McIntyre. The Psychological Impact of War Trauma on Civilians: An International Perspective. Westport, Conn.; London: Praeger, 2003.

Lanchner, Carolyn, ed. Paul Klee: His Life and Work. New York: Hatje Cantz Publishers, 1987. 
Langmuir, Erika. Imaging Childhood. New Haven and London: Yale University Press, 2006.

Levine, Frederick S. The Apocalyptic Vision: The Art of Franz Marc as German Expressionism. New York: Harper and Row Publishers, 1979.

Lewis, C. S. "On Juvenile Tastes." In Of Other Worlds. New York: Harcourt, Brace \& World, 1966.

---. The Allegory of Love. Oxford: Oxford University Press, 1936.

Liebau, Eckart. "Kind und Kunst: Das schöpferische Kind.” In Ellen Key's Reformpädagogische Vision, edited by Meike Sophia Baader, Juliane Jacobi, Sabine Andresen, 191-214. Beltz: Taschenbuch, 2000.

Lipsey, Roger. The Spiritual in Twentieth-Century Art. Boston and Shaftesbury: Shambhala, 1988.

Littlejohns, Richard. "Philipp Otto Runge's Tageszeiten and Their Relationship to Romantic Nature Philosophy.” Studies in Romanticism 42, no. 1 (Spring, 2003): 5574.

Loach, Loretta. The Devil's Children: A History of Childhood and Murder. London: Icon Books Ltd., 2009.

Locke, John. Two Treatises on Government. Edited by Peter Laslett. Cambridge:

Cambridge University Press, 1988.

Lowenfeld, Viktor. Creative and Mental Growth. New York: Macmillan and Co., 1947.

Malchiodi, Cathy A., ed. Handbook of Art Therapy. New York; London: The Guilford Press, 2003.

Marsh, Ellen. "Paul Klee and the Art of Children: A Comparison of their Creative Processes." College Art Journal 16, no. 2 (Winter, 1957): 132-145.

Martin, Bernard. A History of Judaism, Vol. 2. New York: Basic Books, Inc., 1974.

Moran, Joe. "Childhood and Nostalgia in Contemporary Culture." European Journal of Cultural Studies 5, no. 2 (2002): 155-173.

Naubert-Riser, Constance. La Création Chez Paul Klee: Étude de la relation theoriespraxis de 1900 à 1924. Paris: Éditions Klincksieck, 1978.

Newton, Michael. Savage Girls and Wild Boys: A History of Feral Children. New York: 
St. Martin's Press, 2002.

Newman, Jacob. Judaism A-Z: lexicon of terms and concepts. Jerusalem: Department for Torah Education and Culture in the Diaspora of the World Zionist Organization, 1980.

Novalis. The Novices of Saïs. Translated by Ralph Manheim. Brooklyn, N.Y: Archipelago Books, 2005.

Osterwold, Tilman. Paul Klee: ein Kind träumt sich. Stuttgart: Verlag Gerd Hatje, 1979.

Ovortrup, Jens, ed. Childhood Matters: Social Theory, Practice, and Politics. Aldershot, UK: Avebury, 1994.

Partsch, Susanna. Paul Klee, 1879-1940. Köln: Taschen Basic Art, 1993.

Pattison, Robert. The Child Figure in English Literature. Athens: University of Georgia Press, 1978.

Pecora, Norma Odom. The Business of Children's Entertainment. New York and London: The Guilford Press, 1998.

Pellowski, Anne. The World of Storytelling. Bronx, New York: H. W. Wilson, 1990.

Perry, Gill, Charles Harrison and Francis Frascina. Primitivism, Cubism, Abstraction: the Early Twentieth Century. New Haven: Yale University Press, 1993.

Pierce, James Smith. Paul Klee and Primitive Art. New York: Garland Publishers., 1976.

Pollock, Linda A. Forgotten Children: Parent-child Relations from 1500-1900.

Cambridge and New York: Cambridge University Press, 1983.

Proust, Alan, ed. The Body, Childhood and Society. London: Macmillan Press, Ltd., 2000.

Raboff, Ernest. Paul Klee: Kunst Für Kinder. Genf: Pappband, 1969.

---. Art for Children: Paul Klee. New York: Harper Collins, 1988.

Read, Herbert. Paul Klee on Modern Art. London: Faber and Faber Ltd., 1966.

Rhodes, Colin. Primitivism and Modern Art. London: Thames and Hudson Ltd., 1994.

Ricci, Corrado. L'arte dei bambini. Bologna: Nicola Zanichelli, 1887. 
Richards, Martin and Paul Light, ed. Children of Social Worlds: Development in a Social Context. Cambridge: Polity, 1986.

Richter, Dorothea. "Die kühle Romantik dieses Stils ohne Pathos ist unerhört." In Paul Klee und die Romantik, edited by Brigitte Reinhardt, Dorothea Richter, and Tulliola Sparagni, 27-40. Ulm: Hatje Cantz and Ulmer Museum, 2009.

Riedweg, Christoph. Pythagoras: His Life, Teaching, and Influence. Translated by Steven Rendall. Ithaca and London: Cornell University Press, 2002.

Robertson, R., ed. E.T.A. Hoffmann: The Golden Pot and Other Tales. New York: Oxford University Press, 1992.

Rose, Jacqueline. "State and Language: Peter Pan as Written for the Child," in Language, Gender and Childhood, edited by Carolyn Steedman, Cathy Urwin, and Valerie Walkerdine, 88-92. London: Routledge, 1985.

Rumelin, Christian. Animal Tricks: Paul Klee. New York: Prestel Publishing, 2002.

Schaprio, Meyer. "Courbet and Popular Imagery: An Essay on Realism and Naiveté." Journal of the Warburg and Courtauld Institutes 4, nos. 3-4 (1941): 173-80

Schemm, Juergen von. Dreaming Pictures: Paul Klee. New York: Prestel Publishing USA, 1998.

Schmalenbach, Werner. Paul Klee: Die Düsseldorf Sammlung. Munich: Prestel-Verlag, 1986.

Scholz, Dieter. "Kindheit." In Das Universum Klee, edited by Dieter Scholz and Christina Thomson, 96-97. Berlin: Hatje Cantz, 2008.

Schreyer, Lothar. Erinnerungen an Sturm und Bauhaus. Munich: Albert and Langen, George Müller, 1956.

Silver, Richard M. "Captive of Art, not Disease. Paul Klee and his Illness, Scleroderma." The Pharos of Alpha Omega 71, no. 1 (2008): 16-24.

Smith, William. Dictionary of Greek and Roman Biography and Mythology. Boston: Little, Brown, and Company, 1867.

Sommerville, C. John. The Rise and Fall of Childhood. Sage Library of Social Research, Vol. 140. Beverly Hills: Sage Publications Inc., 1982.

Sparagni, Tulliola. "Paul Klee und die Romantik." In Paul Klee und die Romantik, edited by Brigitte Reinhardt, 9-27. Hatje Cantz and Ulmer Museum, 2009. 
Story, Ala. Paul Klee: Oils, Watercolors, Gouaches, Drawings, Prints from the James Gilvarry Collection. Santa Barbara, California: The Art Gallery of the University of California, 1967.

Stuckley, Charles F. "Monet's Art and the Act of Vision." In Aspects of Monet: A Symposium on the Artist's Life and Times, edited by John Rewald and Frances Weitzenhoffer. New York: Abrams, 1984.

Taylor, Joshua C., ed. Nineteenth-Century Art Theories. Berkeley: University of California Press, 1987: 178-79.

Tipton, Frank B. A History of Modern Germany Since 1815. London: The Continuum International Publishing Group, 2003.

Trodd, Tamara. "Drawing in the Archive: Paul Klee's Oil Transfers," Oxford Art Journal 1, no. 32 (2008): 75-95.

Tuchman, Maurice, ed. The Spiritual in Art: Abstract Painting 1890-1985. New York: Abbeville Press, 1986.

Tucker, Nicolas. What is a Child? London: Fontana/Open Books, 1977.

Varga, John. "Illness and Art: The Legacy of Paul Klee." Current Opinion in Rheumatology 16, no. 6 (Nov. 2004): 714-7.

Veer, Peter van der. "Spirituality in Modern Society" Social Research 76, no. 4 (Winter 2009): 1097-1120.

Verdi, Richard. Klee and Nature. London: A. Zwemmer Ltd., 1984.

Waggoner, Diana. The Hills of Faraway: A Guide to Fantasy. New York: Atheneum, 1978.

Walkerdine, Valerie. "Popular Culture and the Eroticization of Little Girls." In The Children's Culture Reader, edited by Henry Jenkins, 254-264. New York and London: New York University Press, 1998.

Warner, Maria. No Go the Bogeyman: Scaring, Lulling, and Making Mock. London: Chatto and Windus, 1999.

Washington, Peter. Madame Blavatsky's Baboon: Theosophy and the Emergence of the Western Guru. London: Secker \& Warburg, 1993.

Weinstock, Michael. “Can Architectural Design be Research?” Architectural Design 78, 
no. 4 (July, 2008): 126-129.

Welsh, Robert. Piet Mondrian's Early Career: The "Naturalistic” Periods. New York: Garland, 1977.

Werblowsky, R. J. Zwi and Geoffrey Wigoder ed. The Encyclopaedia of the Jewish Religion. New York: Holt, Rinehart and Winston, Inc., 1966.

Werckmeister, Otto Karl. Ende der Ästhetik. Frankfurt: S. Fischer, 1971.

---. "The Issue of Childhood in the Art of Paul Klee." Arts Magazine 52, no. 1 (September 1977): 138-151.

---. The Making of Paul Klee's Career, 1914-1920. Chicago: University of Chicago Press, 1989.

---. Versuche über Paul Klee. Frankfurt am Main: Syndikat, 1981.

Whitford, Frank. Bauhaus. London: Thames and Hudson, 1984.

Wilson, John P., ed. The Posttraumatic Self: Restoring Meaning and Wholeness to Personality. New York: Routledge, 2006.

Wojcik-Andrews, Ian. Children's Films: History, Ideology, Pedagogy, Theory. New York and London: Garland Publishing, Inc., 2000.

Wolfe, Gillian. Look! Drawing the Line in Art. Francis Lincoln, 2008.

Wörwag, Barbara. “"There is an Unconscious, Vast Power in the Child:' Notes on Kandinsky, Münter and Children's Drawings.' In Discovering Child Art, edited by Jonathan Fineberg, 68-94. Princeton: Princeton University Press, 1998.

Wringley, E. A. and R. S. Schofield. The Population History of England 1541-1871: A Reconstruction. Cambridge: Cambridge University Press, 1981.

Wünsche, Isabel, ed. Galka E. Scheyer and the Blue Four: Correspondence 1924-1945. Waben/Bern: Benteli Verlags AG, 2006.

Zipes, Jack, ed. The Great Fairy Tradition: From Straparola and Basile to the Brothers Grimm. New York: W. W. Norton and Co. Inc., 2001. 